\begin{tabular}{|c|c|}
\hline$\Delta^{N} \lambda^{q^{\prime}}$ & INFORMATION CLEARANCE FORM \\
\hline A. Information Category & B. Document Number RPP -4773 \\
\hline $\begin{array}{ll}\square \text { Abstract } & \square \text { Joumal Artide } \\
\square \text { Summary } & \square \text { Internet } \\
\square \text { Visual Ald } & \square \text { Software } \\
\square \text { Full Paper } & \square \text { Report }\end{array}$ & $\begin{array}{l}\text { C. Title } \\
\text { River Protection Project Information Systems Assessment }\end{array}$ \\
\hline$\square$ other _ـ & D. internet Address \\
\hline
\end{tabular}

E. Required Information

1. Is document potentially Classified? ONo OYes (MANDATORY) lee below for piegnature Manage s Signature Required

If Yes ADC Signatuje Réquired

Ono Oyes classified

2. Internal Review Required? if Yes, Document Signatures Below

Ono OYes

Counsel

Program

3. References in the Information are Applled Technology ONo OYes

Export Controlled information
4. Does information Contain the Following: (MANDATORY)

a. New or Novel (Patentable) Subject Matter? ONo OYes

If "Yes", Disclosure No.:

b. Information Recelved in Confidence, Such as Proprietary and/or inventions?

ONo OYes if "Yes", Affix Appropriate Legends/Notices.

c. Copyrights? QNo OYes If "Yes", Attach Permission.

d. Trademarks? CNo OYés

5. Is Information requiring submission to OSTI? $\bigcirc$ No $\bigcirc$ Yes

If Yes UC-_ and B\&R -

6. Release Level? $O$ Public $\bigcirc$ Limiled

7. Chiarge Code

F. Complete for a Journal Article

1. Title of Joumal

G. Complete for a Presentation

1. Title for Conference or Meetng

2. Group Sponsoring

3. Date of Conference

5. Will information be Published in Proceedings? $O$ No OYes

4. City/State

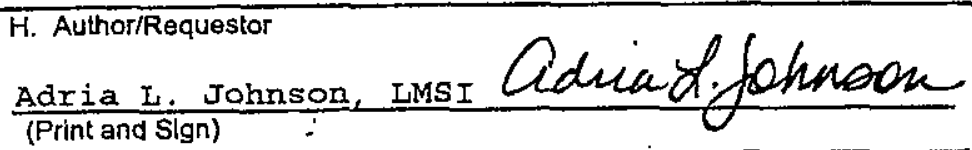

6. Will Material be Handed Out?

Responsible Manager

I. Reviewers

Yes Print

General counsel WmH VU.F. WiLlis

Lyle G. Peck, RPE

(Print and Sign)

Office of External Affairs

DOE-RL

$\square$

$N / A$

signglurelly llis

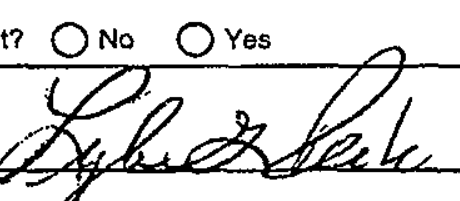

Other

[2) H.J. WACEK

Other
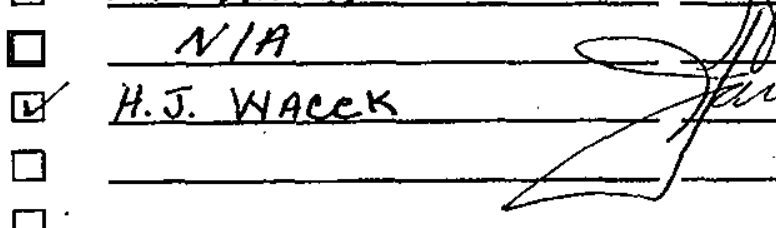

J. If information Includes Sensltive information and is not to be released to the Public indicate category below.
$\square$ Applied Technology
Dersonal/Private
$\square$ Protected CRADA
Droprletary
$\square$ Export Controlled
$\square$ Business-Sensitive
$\square$ Procurernent-Sensitive
$\square$ Predecisional
$\square$ Patentable
$\square$ UCNI
$\square$ Other (Specify)

K. If Additional Comments, Please Altach Separate Sheet 
RPP-4773, Rev. 0

S

\section{River Protection Project Information Systems Assessment}

Prepared for the U.S. Department of Energy

FLUOR DANIEL HANFORD, INC.

Richland, Washington

Hanford Management and Integration Contractor for the

U.S. Department of Energy under Contract DE-AC06-96RL13200

Approved for Public Release; Further Dissemination Unlimited 
LEGAL DISCLAIMER

This report was prepared as an account of work sponsored by an agency of the United States Government. Neither the United States Government nor any agency thereof, nor any of their employees, nor any of their contractors, subcontractors or their employees, makes any warranty, express or implied, or assumes any legal liability or responsibility for the accuracy, completeness, or any third party's use or the results of such use of any information, apparatus, product, or process disclosed, or represents that its use would not infringe privately owned rights. Reference herein to any specific commercial product, process, or service by trade name, trademark, manufacturer, or otherwise, does not necessarily constitute or imply its endorsement, recommendation, or favoring by the United States Government or any agency thereof or its contractors or subcontractors. The views and opinions of authors expressed herein do not necessarily state or reflect those of the United States Government or any agency thereof.

This report has been reproduced from the best available copy.

Available in paper copy and microfiche.

Available to the U.S. Department of Energy and its contractors from

U.S. Department of Energy

Office of Scientific and Technical Information (OST)

P.O. Box 62

Oak Ridge, TN 37831

(615) $576-8401$

Available to the public from the U.S. Department of Commerce

National Technical Information Service (NTIS)

5285 Port Royal Road

Springfield, VA 22161

(703) $487-4650$

Printed in the United States of America

DISCLM-1.CHP (8-95) 


\title{
River Protection Project Information Systems Assessment
}

\author{
A. M. David \\ Lockheed Martin Hanford Corporation
}

Date Published

July 1999

Prepared for the U.S. Department of Energy

FLUOR DANIEL HANFORD, INC.

Richland, Washington

Hanford Management and Integration Contractor for the

U.S. Department of Energy under Contract DE-ACO6-96RL13200

Approved for Public Release; Further Dissemination Unlimited 


\section{RELEASE AUTHORIZATION}

Document

Number:

Document

Title:
RPP-4773, Rev. 0

River Protection Project Information Systems

Assessment

This document, reviewed in accordance with DOE Order 241.1, "Scientific and Technical Information Management," and DOE G 241.1-1, "Guide to the Management of Scientific and Technical Information," does not contain classified or sensitive unclassified information and is:

\section{APPROVED FOR PUBLIC RELEASE}

\begin{tabular}{|c|c|}
\hline (hristine) Mrillingand & $7 / 27 / 99$ \\
\hline $\begin{array}{l}\text { Lockheed Mart in Services, Inc. } \\
\text { Document Control/Information clearance }\end{array}$ & \\
\hline
\end{tabular}

Reviewed for Applied Technology, Business Sensitive, Classified, Copyrighted, Export Controlled, Patent, Personal/Private, Proprietary, Protected CRADA, Trademark, Unclassified Controlled Nuclear Information.

LEGAL DISCLAIMER. This report was prepared as an account of work sponsored by an agency of the United States Government. Neither the United States Government nor any agency thereof, not any of their employees, nor any of their contractors, subcontractors or their employees, makes any warranty, express or implied, or assumes any legal liability or responsibility for the accuracy, completeness, or any third party's use or the results of such use of any information, apparatus, product, or process disclosed, or represents that its use would not infringe privately owned rights. Reference herein to any specific commercial product, process, or service by trade name, trademark, manufacturer, or otherwise, does not necessarily constitute or imply its endorsement, recommendation, or favoring by the United states Government or any agency thereof or its contractors or subcontractors. The views and opinions of authors expressed herein do not necessarily state or reflect those of the United states Government or any. agency thereof. This report has been reproduced from the best avaitable copy. Printed in the United States of America. 
RPP-4773, Rev. 0

This page intentionally left blank. 
RPP-4773, Rev. 0

Document Title: River Protection Project Information Systems Assessment
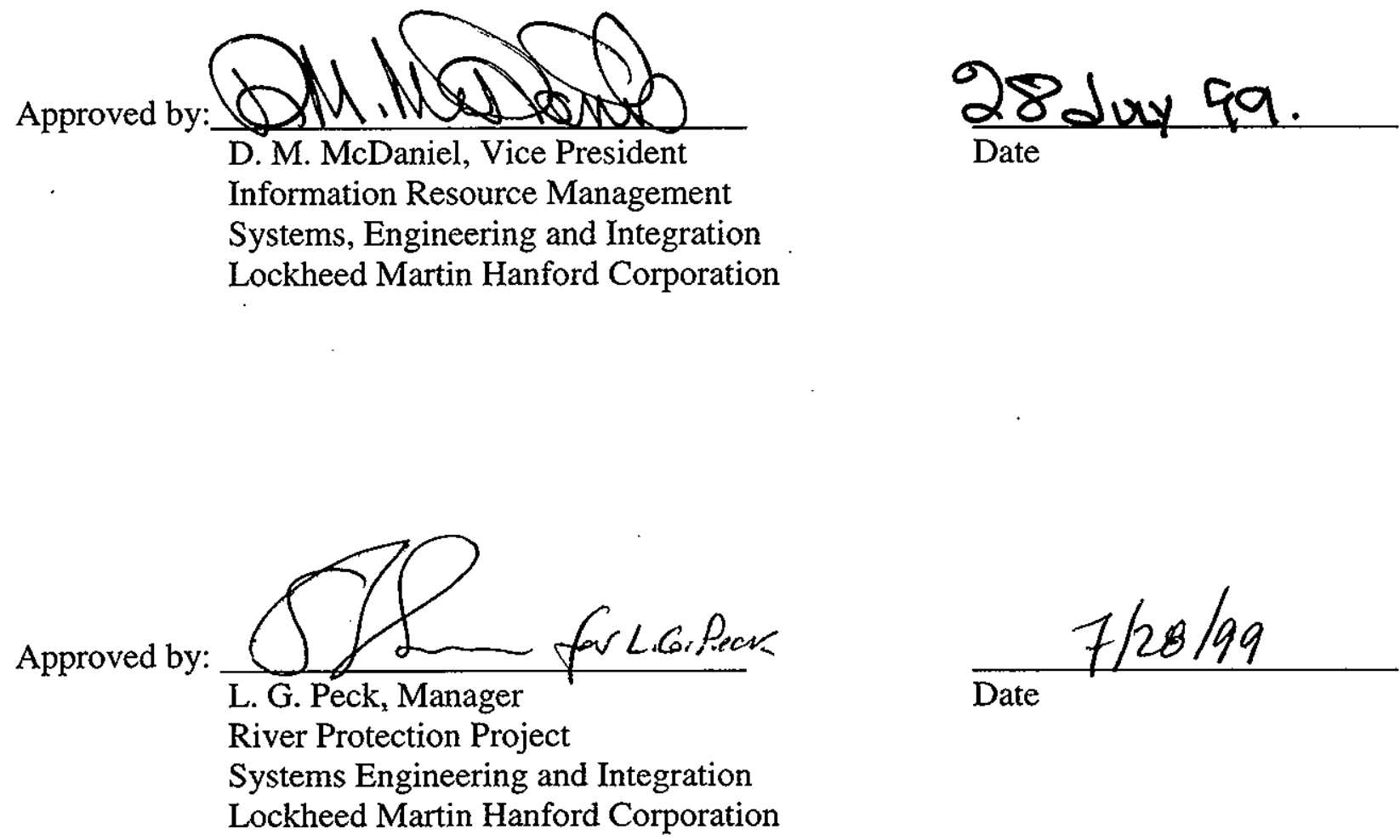

Date

Date 
RPP-4773, Rev. 0

This page intentionally left blank. 
RPP-4773, Rev. 0

\section{EXECUTIVE SUMMARY}

In closure to Performance Agreement 7.1.1, "Provide an assessment report on the selected Integrated Information System by July 31, 1999, " Fluor Daniel Hanford, Inc., and Lockheed Martin Hanford Corporation (LMHC) respectfully submit our assessment report.

The U.S. Department of Energy Office of River Protection initiated this information system assessment to provide understanding of how information systems implemented or proposed by the Project Hanford Management Contract (PHMC) assist project managers in accomplishing their projects in a disciplined fashion. The "Systems Engineering Maturity Assessment Process Assessment Questionnaire" (see Appendix D or Hanford internal web site http://www.rl.gov:1050/RPP/syseng/se proc.htm) established the guidance for assessing the organization's maturity in the application of key focus areas. The questionnaire is based on the International Council on Systems Engineering (INCOSE), System Engineering Capability Assessment Model Version 1.5. In accordance with the performance agreement criteria, this assessment provides a gap analysis and recommendations regarding the integrated information system and the needs of project managers as stated or implied by the questionnaire.

The project to perform this assessment examined the PHMC electronic information system commonly known as "HANDI 2000". As applied to the project, this system involves components that are currently implemented under the PHMC as well as many components that are planned to be implemented.

The assessment identifies six information gap areas where the HANDI 2000 system fails to support the comprehensive needs of project managers. Note, however, a large majority of 
HANDI 2000 components have yet to be funded and implemented: work management, engineering change control, project management, action tracking, and document management. If not implemented, the information needs gap increases significantly causing project managers to operate at risk in the River Protection Project's highly volatile decision and work environment.

The information gaps consolidate to six functional categories: (1) project schedule management, (2) requirements management, (3) information reporting, (4) configuration management, (5) process management, and (6) risk management. Project scheduling gaps are resolved by reusing a software component developed earlier by LMHC. Requirements management gap resolution calls for features available in newer requirements management systems. An upgrade to the current site standard meets the needs. LMHC recommends data warehouse and report writer tools to support general access to business and technical information on a regular or ad hoc basis. For configuration management, LMHC recommends a configuration management system with a bias toward Indus International, Inc.'s Curator product. The same product is recommended for process management of processes not well suited to the HANDI 2000 project, work order, or action transactions. Risk management recommendations call for the continued investigation of the return on investment for a risk management system.

The River Protection Project fiscal year 2000 budget will propose these information solutions to the Office of River Protection for their consideration. We trust you will find this report valuable in prioritizing the need to implement the recommendations within. 


\section{CONTENTS}

1.0 PURPOSE. $1-1$

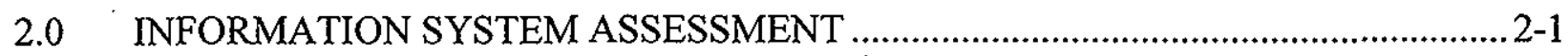

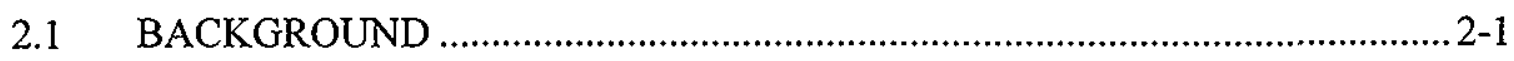

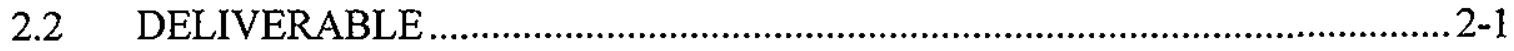

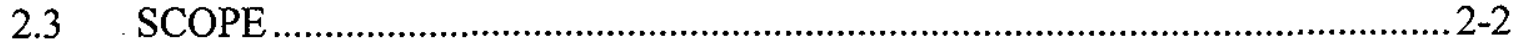

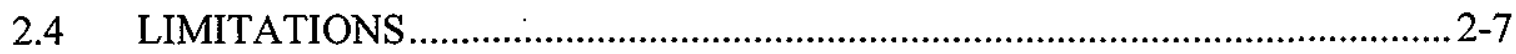

2.5 ASSUMPTIONS ....................................................................................... 2-7

3.0 SYSTEM SELECTION AND DEFINITION ............................................................ $3-1$

4.0 INFORMATION CAPABILITY REQUIREMENTS ................................................. 4-1

4.1 MATURITY ASSESSMENT GUIDE QUESTIONNAIRE/ INFORMATION SUBJECT CORRELATION MATRIX................................... 4-1

4.2 ORGANIZATION OF WORK ………………............................................ 4-3

4.3 REQUIREMENTS................................................................................... 4-4

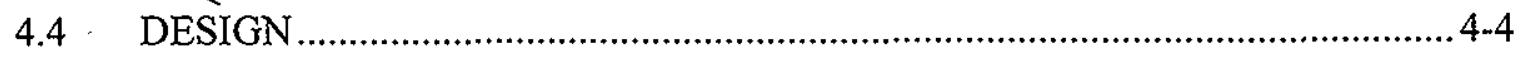

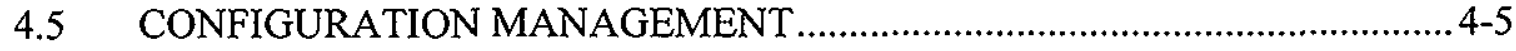

4.6 QUALITY MANAGEMENT ………………............................................ 4-5

4.7 RISK INFORMATION ……………………........................................ 4-5

4.8 TECHNICAL PERFORMANCE .................................................................. 4-6

4.9 PROJECT INFORMATION ......................................................................... $4-6$

4.10 CONCURRENT ENGINEERING ………................................................. 4-7

4.11 INTERFACES ..................................................................................... 4-7

4.12 PLANS ....................................................................................................... 4-7

5.0 MATURITY ASSESSMENT/INFORMATION CAPABILITY AND FUNCTIONALITY MATRIX ......................................................................... 5-1

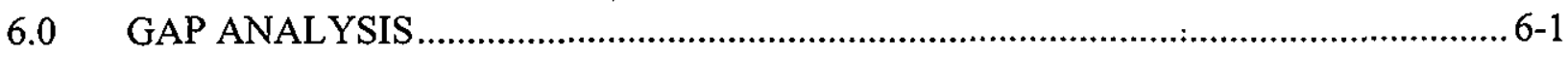

6.1 PROJECT SCHEDULING GAP ANALYSIS ................................................ 6-1

6.2 REQUIREMENTS MANAGEMENT GAP ANALYSIS ..................................6-2

6.3 INFORMATION REPORTING AND ACCESS GAP ANALYSIS.................... 6-3

6.4 CONFIGURATION MANAGEMENT GAP ANALYSIS .................................. 6-4

6.5 PROCESS MANAGEMENT GAP ANALYSIS................................................ 6-6

6.6 RISK MANAGEMENT PROCESS GAP ANALYSIS ...................................... 6-7 
7.0 RECOMMENDATIONS FOR GAP RESOLUTION

7.1 RECOMMENDATIONS FOR PROJECT SCHEDULING

7.2 RECOMMENDATIONS FOR REQUIREMENTS MANAGEMENT

7.3 RECOMMENDATIONS FOR INFORMATION REPORTING AND ACCESS $7-6$

7.4 RECOMMENDATIONS FOR CONFIGURATION MANAGEMENT .............7-8

7.5 RECOMMENDATIONS FOR PROCESS MANAGEMENT.

7.6 · RECOMMENDATIONS FOR RISK MANAGEMENT

\section{APPENDICES}

APPENDIX A NOTES OF AGREEMENTS REACHED ON CONTENTS OF INFORMATION SYSTEMS ASSESSMENT

APPENDIX B PERFORMANCE AGREEMENT 7.1.1 B-i

APPENDIX C INFORMATION SYSTEM ASSESSMENT PROCESS $\mathrm{C}-\mathrm{i}$ APPENDIX D SYSTEMS ENGINEERING MATURITY ASSESSMENT PROCESSASSESSMENT QUESTIONNAIRE D-i

APPENDIX E PROJECT HANFORD MANAGEMENT PROJECT HANDI 2000 MODULE DESCRIPTIONS

APPENDIX F ACRONYMS F-i

APPENDIX G REFERENCES AND BIBLIOGRAPHY G-i

APPENDIX H INFORMATION SYSTEMS ASSESSMENT PROJECT PARTICIPANTS. $\mathrm{H}-\mathrm{i}$

APPENDIX I PRIORITIES FOR IMPLEMENTATION AND DEVELOPMENT ACTIVITIES. 
RPP-4773, Rev. 0

\section{LIST OF FIGURES}

2-1. Project Hanford Management Contract HANDI 2000 System Module Integration. $2-6$

7-1. A Project Scheduling Approach .. $.7-2$

7-2. A Requirements Management Approach. $7-5$

7-3. An Executive Reporting and Access Approach. 7-7

7-4. A Configuration Management Approach $7-10$

7-5. A Process Management Approach using HANDI 2000 Work Orders $7-13$

7-6. A Process Management Approach Using a Workflow System. $7-14$

7-7. A Risk Management Approach $7-16$ 
RPP-4773, Rev. 0

\section{LIST OF TABLES}

2-1. Information Topics $2-3$

2-2. Project Hanford Management Contract HANDI 2000 System Modules. $2-5$

4-1. Maturity Assessment Guide Questionnaire/Information Subject Correlation Matrix.

5-1. Maturity Assessment/Information Capability and Functionality Matrix. $5-2$

6-1. Information Needs Related to Project Scheduling Gap Analysis.

6-2. Information Needs Related to Requirements Management Gap Analysis. $6-2$

6-3. Information Needs Related to Information Reporting and Access Gap Analysis. $6-3$

6-4. Information Needs Related to Configuration Management. 6-4

6-5. Information Needs Related to Process Management Gap Analysis. 6-6

6-6. Information Needs Related to the Risk Management Process Gap Analysis.

7-1. Information Needs Related to Recommendations for Project Scheduling. $7-1$

7-2. Information Needs Related to Recommendations for Requirements Management. . -3

7-3. Information Needs Related to Recommendations for Configuration Reporting and Access. $7-6$

7-4. Information Needs Related to Recommendations for Configuration Management. $7-8$

7-5. Information Needs Related to Recommendations for Process Management. $7-11$

7-6. Information Needs Related to Recommendations for Risk Management. $7-15$ 
RPP-4773, Rev. 0

\subsection{PURPOSE}

The Information Systems Assessment Report documents the results from assessing the Project Hanford Management Contract (PHMC) Hanford Data Integrator 2000 (HANDI 2000) system, Business Management System (BMS) and Work Management System phases (WMS), with respect to the System Engineering Capability Assessment Model (CAM). The assessment was performed in accordance with the expectations stated in the fiscal year (FY) 1999 Performance Agreement 7.1.1, item (2) which reads, "Provide an assessment report on the selected Integrated Information System by July 31, 1999."

This report assesses the BMS and WMS as implemented and planned for the River Protection Project (RPP). The systems implementation is being performed under the PHMC HANDI 2000 information system project. The project began in FY 199.8 with the BMS, proceeded in FY 1999 with the Master Equipment List portion of the WMS, and will continue the WMS implementation as funding provides. This report constitutes an interim quality assessment providing information necessary for planning RPP's information systems activities. To avoid confusion, HANDI 2000 will be used when referring to the entire system, encompassing both the BMS and WMS. A graphical depiction of the system is shown in Figure 2-1 of this report. 
RPP-4773, Rev. 0

This page intentionally left blank. 
RPP-4773, Rev. 0

\subsection{INFORMATION SYSTEM ASSESSMENT}

\subsection{BACKGROUND}

The U.S. Department of Energy (DOE) Office of River Protection (ORP) initiated this information system assessment to provide understanding of how information systems implemented or proposed by the PHMC assist project managers in accomplishing their projects in a disciplined fashion. The Systems Engineering Maturity Assessment Process Assessment Questionnaire (see Appendix D or Hanford internal web site http://www.rl.gov:1050/RPP/syseng/se proc.htm) established the guidance for assessing the organization's maturity in the application of key focus areas.

The questionnaire is based on the International Council on Systems Engineering (INCOSE), System Engineering CAM, Version 1.5. The model states performance maturity in terms of 6 levels, Level 0 being the initial level and Level 5 being the highest quality performance. The INCOSE model includes questions pertaining to Levels 1 through 5. The questionnaire includes questions from Levels 1 through 3 . If answered favorably, the questionnaire would consider a project to be performing at maturity Level 3, a performance level acceptable to the general business community. Higher levels address incremental risk reduction and performance optimization.

In order to perform the assessment, ORP and RPP analyzed the questionnaire items to develop a list of implicit information requirements. Not all of the questionnaire items implied information requirements, and some implied multiple information requirements. The analysis resulted in the "information topics" listed in Section 2.3.

The value of the assessment report is grounded in the recommendations (Section 7.0) regarding gaps (i.e., weaknesses and voids) in information essential to successful project performance. The recommendations are intended to influence the priority of RPP information system projects for the future.

\subsection{DELIVERABLE}

The performance agreement (PA) deliverable is an assessment report formed as follows:

- The contractor selects and defines an RPP integrated information system

- The contractor assesses the ability of that information system to provide information through Level 3 of the systems engineering maturity model for the RPP, as defined by the current RPP system engineering maturity assessment procedure in HNF-IP-0842, RPP Administration.

- The contractor delivers a report describing the information system, the assessment methods, and results and identifying gaps requiring resolution. 
RPP-4773, Rev. 0

\subsection{SCOPE}

The scope of this report includes the information topics listed in Table 2-1 and the PHMC HANDI 2000 system modules listed in Table 2-2. Table 2-2 also shows the implementation status of each module (i.e., implemented, implementation in process, or proposed for implementation. Figure 2-1 shows the PHMC HANDI 2000 system modules and their interrelationships. 
RPP-4773, Rev. 0

Table 2-1. Information Topics. (2 sheets)

\begin{tabular}{|c|c|}
\hline Topic Category & Topic Detail Item \\
\hline \multirow[t]{4}{*}{ Organization of Work } & Program/project life-cycles \\
\hline & Work breakdown structure \\
\hline & Event driven plan (activity based or logic driven) \\
\hline & Logic diagrams (to depict predecessor; successor relationships) \\
\hline \multirow[t]{8}{*}{ Requirements } & Customer/user needs and constraints \\
\hline & Stakeholder constraints \\
\hline & User requirements baseline \\
\hline & Subsystem requirements \\
\hline & Documentation of requirements verification criteria \\
\hline & Documentation of verification results \\
\hline & Requirements relationships \\
\hline & Management of changes to requirements \\
\hline Design & $\begin{array}{l}\text { Generic issue in design: Design review criteria should be available to } \\
\text { all involved }\end{array}$ \\
\hline \multirow{3}{*}{$\begin{array}{l}\text { Configuration } \\
\text { Management }\end{array}$} & Configuration items are identified \\
\hline & Configuration items are statused \\
\hline & $\begin{array}{l}\text { Configuration items are developed from system requirements by } \\
\text { appropriate teams }\end{array}$ \\
\hline \multirow{4}{*}{$\begin{array}{l}\text { Quality Management } \\
\text { (QM) }\end{array}$} & Evaluations and assessments are reported to all affected parties \\
\hline & Evaluations and assessments are available \\
\hline & Quality Management activities are statused for conformance to plans \\
\hline & Documented and approved quality assurance acceptance criteria \\
\hline
\end{tabular}


Table 2-1. Information Topics. (2 sheets)

\begin{tabular}{|c|c|}
\hline Topic Category & Topic Detail Item \\
\hline \multirow[t]{6}{*}{ Risk Information } & $\begin{array}{l}\text { Cost, resource, schedule, and technical risks-identification, analysis, } \\
\text { and mitigation }\end{array}$ \\
\hline & Visible to Project Manager \\
\hline & Risk thresholds \\
\hline & Risk Management List \\
\hline & Risks of different system concepts (alternatives) \\
\hline & Risks considered in tradeoff studies \\
\hline \multirow[t]{3}{*}{ Technical Performance } & $\begin{array}{l}\text { Technical performance measures-identified, documented, and } \\
\text { distributed }\end{array}$ \\
\hline & Technical Performance Measurement Assessment Plan \\
\hline & Master Measurement List \\
\hline \multirow[t]{5}{*}{ Project Information } & Archiving/retrieving Project Information \\
\hline & $\begin{array}{l}\text { Relationships between requirements and interface documents } \\
\text { (specification tree) }\end{array}$ \\
\hline & $\begin{array}{l}\text { Relationships between drawings of physical elements of the system } \\
\text { (drawing tree) }\end{array}$ \\
\hline & Relationships between software elements and interfaces \\
\hline & Status of Project Information (at any given time) \\
\hline $\begin{array}{l}\text { Concurrent } \\
\text { Engineering }\end{array}$ & $\begin{array}{l}\text { Concurrent engineering information is passed between the groups } \\
\text { involved in concurrent engineering }\end{array}$ \\
\hline \multirow[t]{2}{*}{ Interfaces } & Interfaces identified/managed \\
\hline & Interface Control Documents \\
\hline \multirow[t]{4}{*}{ Plans } & Technical management plan (Systems Engineering Management Plan) \\
\hline & Decisions/rationale recorded and traced \\
\hline & Planning and control metrics monitored/used \\
\hline & $\begin{array}{l}\text { Inputs/outputs of systems engineering process activities clearly } \\
\text { identified (Project Management Plan, logic diagrams, work plans, } \\
\text { Systems Engineering Management Plan) }\end{array}$ \\
\hline
\end{tabular}


RPP-4773, Rev. 0

Table 2-2. Project Hanford Management Contract HANDI 2000 System Modules.

\begin{tabular}{|c|c|c|}
\hline Module Name & Supplier & Implementation Status \\
\hline Inventory & PassPort $^{1}$ & Implemented* \\
\hline Material Safety Data Sheet & PassPort ${ }^{\mathrm{TM}}$ & Implemented* \\
\hline Contract Management & PassPort ${ }^{\mathrm{TM}}$ & Implemented* \\
\hline Purchasing & PassPort ${ }^{\mathrm{TM}}$ & Implemented $*$ \\
\hline Accounts Payable & PeopleSoft ${ }^{2}$ & Implemented* \\
\hline General Ledger & PeopleSoft ${ }^{\mathrm{TM}}$ & Implemented* \\
\hline Payroll & PeopleSoft ${ }^{\mathrm{TM}}$ & Implemented* \\
\hline Project & PeopleSoft ${ }^{\mathrm{TM}}$ & Implemented* \\
\hline Human Resources/Training & PeopleSoft ${ }^{\mathrm{TM}} / \mathrm{FDH}$ & Implemented* \\
\hline P3 Site Schedule & Primavera & Implemented* \\
\hline Performance & FDH & Implemented* \\
\hline Deficiency Tracking System & PassPort ${ }^{\mathrm{TM}}$ & Implemented* \\
\hline Document Management & PassPort ${ }^{\mathrm{TM}}$ & Proposed \\
\hline Engineering Change Control & PassPort ${ }^{\mathrm{TM}}$ & Proposed \\
\hline Action Tracking & PassPort ${ }^{\mathrm{TM}}$ & Proposed \\
\hline Project Control & PassPort $^{\mathrm{TM}}$ & Proposed \\
\hline Work Control & PassPort ${ }^{\mathrm{TM}}$ & In Process \\
\hline Labor Entry & PassPort ${ }^{\mathrm{MM}}$ & Proposed \\
\hline Lock and Tag & PassPort ${ }^{\mathrm{TM}}$ & Proposed \\
\hline Personnel Qualification Data & PassPort ${ }^{\mathrm{TM}}$ & Proposed \\
\hline P3 Field Schedules & Primavera & Proposed \\
\hline
\end{tabular}

* Modules identified as "implemented" imply that they are fully operational, implemented through associated procedures, and working as agreed, as planned by HNF-1743, FY 1998 HANDI 2000 Project Plan.

FDH = Fluor Daniel Hanford, Inc.

P3 = Primavera Project Planner ${ }^{3}$

\footnotetext{
${ }^{1}$ PassPort is a trademark of Indus International, San Francisco, California.

${ }^{2}$ PeopleSoft is a trademark of PeopleSoft Inc., Pleasanton, California.

${ }^{3}$ Primavera Project Planner is a trademark of Primavera Systems, Inc., Bala Cynwyd, Pennsylvania.
} 
Figure 2-1. Project Hanford Management Contract HANDI 2000 System Module Integration.

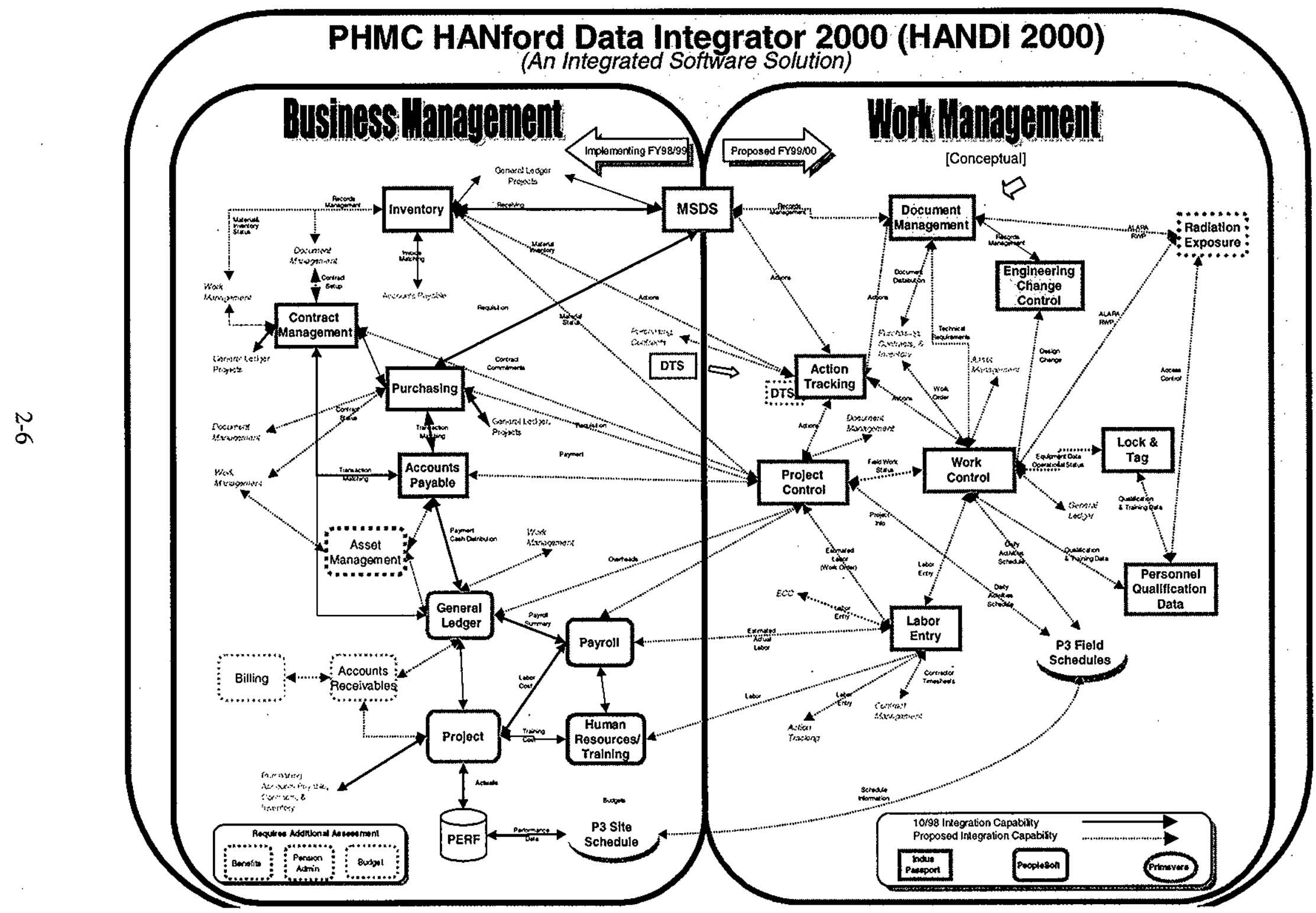


RPP-4773, Rev. 0

\section{$2.4 \quad$ LIMITATIONS}

The project scope limits the assessment to the specific set of information topics listed and described in Section 2.3 and the HANDI 2000 system modules listed in Section 2.3.

In Section 5 of the PA, the word "select" in the clause, "The Contractor selects and defines a RPP Integrated Information System," means to select for assessment purposes. This clause does not imply the selection of a system product for procurement. Nor does the term imply that this report will address which selection criteria were applied to those modules already procured. The clause does not imply that the system modules have been either implemented or procured. The system module status is shown in Table $2-2$.

The user comments in Table 5-1, Column (e) are not intended to be the results of extensive user interviews. Rather, the comments will be from selected qualified contractor personnel who reviewed Table 5-1, Columns (a) through (d). Additionally, the comments were not edited or filtered for the purposes of this report. All comments, regardless of context, were responded to in Column (f).

For the purposes of this report, the Hanford Intranet will not be considered as an integrated information system module. The Intranet is viewed as a reporting mechanism. The contractor strategically plans to use the Intranet for acquiring all information provided by the integrated information system. The Intranet is an infrastructure application, like e-mail, rather than a business application. The Intranet provides a standard look and feel (i.e., computer user interface) mechanism for accessing, viewing, printing, mailing, and navigating through large volumes of information. The Intranet standard user interface has become a world-wide standard like Microsoft Windows ${ }^{4}$. In fact, the Microsoft Corporation plans to use this standard for its Windows ${ }^{\mathrm{TM}}$ product in the near future. The Intranet contains no business rules or database integration such as found in applications like finance and supply systems, work management systems, requirements management systems, or configuration management systems. However, the Intranet can be used to access, present, print, and navigate through the information housed and maintained by the RPP business applications. Lockheed Martin Hanford Corporation (LMHC) proposes to use the Intranet extensively in this manner.

Although LMHC believes that many of the gaps and recommendations included in this report are applicable to all the PHMC, the report only addresses the RPP aspects.

\section{$2.5 \quad$ ASSUMPTIONS}

The following assumptions apply to the system assessment.

- Organizational and cultural issues that may inhibit the changes necessary to make the information system successful will be successfully and timely managed through awareness, training, procedures, management support, and discipline.

${ }^{4}$ Microsoft Windows is a trademark of the Microsoft Corporation in Redmond, Washington. 
- The HANDI 2000 system components as listed in Section 2.3 will be implemented. If these modules are not implemented, then the project management information gaps increase significantly. The obvious areas affected will be cost and schedule baseline control, resource utilization and efficiency, and capturing historical information for future estimating purposes. LMHC will submit an FY 2000 to -FY 2004 budget request, Technical Basis Report (TBR) 710.042, to implement these components, which must be approved for the assumptions to be valid. 
RPP-4773, Rev. 0

\subsection{SYSTEM SELECTION AND DEFINITION}

For the integrated information system, as mandated by Section 5 of the PA, the contractor selects the PHMC HANDI 2000 system comprised of the system modules shown in Table 2-2 of Section 2.3. As indicated in Table 2-2 some of the system modules have been procured, some have been implemented and others have not been procured.

The PHMC HANDI 2000 system is defined as the system that provides cost, scope, and schedule information used by the contractor to direct, control, and monitor its progress toward its contractual and regulatory obligations. The system modules are listed in Section 2.3 of this report and are described in Appendix E, "Project Hanford Management Contractor HANDI 2000 Module Descriptions." 
RPP-4773, Rev. 0

This page intentionally left blank. 


\subsection{INFORMATION CAPABILITY REQUIREMENTS}

As discussed in Section 2.0, the Systems Engineering Assessment Questionnaire provided the basis for identifying the information required by a project manager to successfully execute his job function. To identify these requirements, the questionnaire was reviewed and questions implying a need for information were identified.

\subsection{MATURITY ASSESSMENT GUIDE QUESTIONNAIRE/ INFORMATION SUBJECT CORRELATION MATRIX}

The questions that implied a need for information were grouped together in broad types of information (Information Subjects). The results of this grouping are shown in Table 4-1. The first column of the table lists the question number from the Systems Engineering Assessment Questionnaire, the second column identifies the major grouping (Information Subjects), and the third column summarizes the specific information requirements implied by the question.

Table 4-1. Maturity Assessment Guide Questionnaire/Information Subject Correlation Matrix. (3 sheets)

\begin{tabular}{|c|c|c|}
\hline Question Number & \multicolumn{2}{|r|}{ Information Subjects } \\
\hline $1.1-3.2$ & \multirow[t]{4}{*}{ Organization of Work } & Program/project life-cycles \\
\hline $1.1-1.3$ & & Work breakdown structure \\
\hline $1.1-3.3$ & & $\begin{array}{l}\text { Event-driven plan (activity based or logic } \\
\text { driven) }\end{array}$ \\
\hline $3.5-4.3$ & & $\begin{array}{l}\text { Logic diagrams (to depict predecessor- } \\
\text { successor relationships) }\end{array}$ \\
\hline $3.1-1.3,3.1-2.4$ & \multirow[t]{8}{*}{ Requirements } & Customer/user needs and constraints \\
\hline $3.2-1.4$ & & Stakeholder constraints \\
\hline $3.2-1.4$ & & User requirements baseline \\
\hline $3.2-1.5$ & & Subsystem requirements \\
\hline $3.2-3.5$ & & $\begin{array}{l}\text { Documentation of requirements verification } \\
\text { criteria }\end{array}$ \\
\hline $3.6-2.6$ & & Documentation of verification results \\
\hline $3.2-2.8$ & & Requirements relationships \\
\hline $3.2-2.4$ & & Management of changes to requirements \\
\hline All of Section 3.3 & Design & $\begin{array}{l}\text { Generic issue in design: Design review } \\
\text { criteria should be available to all involved }\end{array}$ \\
\hline
\end{tabular}


Table 4-1. Maturity Assessment Guide Questionnaire/Information Subject Correlation Matrix. (3 sheets)

\begin{tabular}{|c|c|c|}
\hline Question Number & \multicolumn{2}{|r|}{ Information Subjects } \\
\hline $1.5-2.3$ & \multirow{3}{*}{$\begin{array}{l}\text { Configuration } \\
\text { Management }\end{array}$} & Configuration items are identified \\
\hline $1.5-3.2$ & & Configuration items are statused \\
\hline $1.4-3.3$ & & $\begin{array}{l}\text { Configuration items are developed from } \\
\text { system requirements by appropriate teams }\end{array}$ \\
\hline All of Section 1.6 & \multirow[t]{4}{*}{ Quality Management } & $\begin{array}{l}\text { Evaluations and assessments are reported to } \\
\text { all affected parties }\end{array}$ \\
\hline All of Section 1.6 & & Evaluations and assessments are available \\
\hline $1.6-2.7$ & & $\begin{array}{l}\text { Quality Management activities are statused } \\
\text { for conformance to plans }\end{array}$ \\
\hline $1.6-3.2$ & & $\begin{array}{l}\text { Documented and approved quality } \\
\text { assurance acceptance criteria }\end{array}$ \\
\hline $1.1-3.4,1.2-3.2,1.7-1.1$ & \multirow[t]{6}{*}{ Risk Information } & $\begin{array}{l}\text { Cost, resource, schedule, and technical } \\
\text { risks-identification, analysis, and mitigation }\end{array}$ \\
\hline $1.7-1.3$ & & Visible to Project Manager \\
\hline $1.7-3.3$ & & Risk thresholds \\
\hline $1.7-4.3$ & & Risk Management List \\
\hline $3.1-1.4$ & & $\begin{array}{l}\text { Risks of different system concepts } \\
\text { (alternatives) }\end{array}$ \\
\hline $3.1-2.5$ & & Risks considered in tradeoff studies \\
\hline $1.2-3.5$ & \multirow[t]{3}{*}{ Technical Performance } & $\begin{array}{l}\text { Technical performance measures - } \\
\text { identified, documented, and distributed }\end{array}$ \\
\hline $1.2-4.2$ & & $\begin{array}{l}\text { Technical Performance Measurement } \\
\text { Assessment Plan }\end{array}$ \\
\hline $1.2-4.3$ & & Master Measurement List \\
\hline $1.8-1.2$ & \multirow[t]{5}{*}{ Project Information } & Archiving/retrieving Project Information \\
\hline $1.8-1.3$ & & $\begin{array}{l}\text { Relationships between requirements and } \\
\text { interface documents (specification tree) }\end{array}$ \\
\hline $1.8-1.4$ & & $\begin{array}{l}\text { Relationships between drawings of physical } \\
\text { elements of the system (drawing tree) }\end{array}$ \\
\hline $1.8-1.5$ & & $\begin{array}{l}\text { Relationships between software elements } \\
\text { and interfaces }\end{array}$ \\
\hline $1.8-3.4$ & & $\begin{array}{l}\text { Status of Project Information (at any given } \\
\text { time) }\end{array}$ \\
\hline
\end{tabular}


Table 4-1. Maturity Assessment Guide Questionnaire/Information Subject Correlation Matrix. (3 sheets)

\begin{tabular}{|c|c|c|}
\hline Question Number & \multicolumn{2}{|r|}{ Information Subjects } \\
\hline All of Section 1.4 & $\begin{array}{l}\text { Concurrent } \\
\text { Engineering }\end{array}$ & $\begin{array}{l}\text { Concurrent engineering information is } \\
\text { passed between the groups involved in } \\
\text { concurrent engineering }\end{array}$ \\
\hline $3.5-3.3$ & \multirow[t]{2}{*}{ Interfaces } & Interfaces identified/managed \\
\hline $3.5-4.2$ & & Interface control documents \\
\hline $1.1-2.2$ & \multirow[t]{4}{*}{ Plans } & $\begin{array}{l}\text { Technical management plan (Systems } \\
\text { Engineering Management Plan) }\end{array}$ \\
\hline $1.1-2.6$ & & Decisions/rationale recorded and traced \\
\hline $1.2-1.3$ & & $\begin{array}{l}\text { Planning and control metrics } \\
\text { monitored/used }\end{array}$ \\
\hline $2.1-3.3$ & & $\begin{array}{l}\text { Inputs/outputs of systems engineering } \\
\text { process activities clearly identified (Project } \\
\text { Management Plan, logic diagrams, work } \\
\text { plans, Systems Engineering Managment } \\
\text { Plan) }\end{array}$ \\
\hline
\end{tabular}

\subsection{ORGANIZATION OF WORK}

Organization of work includes planning and system integration. Planning involves the identification of technical and programmatic requirements and constraints at the project level. These requirements define the technical and programmatic baseline. System integration is the collection of documentation and processes that result in mutually compatible subsystems that collectively perform to the customer/user needs.

- Program/project life cycles. The entirety of the life span of a program or project, from initial pre-conceptual planning through decontamination and decommissioning.

- Work breakdown structure (WBS). A product-oriented family tree composed of work elements that result from systems engineering efforts and that completely define the program. The WBS defines the product(s) to be developed or produced and relates the elements of work to be accomplished to each other and to the end product. The WBS is structured in accordance with the way in which the work will be performed and reflects the way in which costs will be summarized and eventually reported.

- Event-driven plan (activity based or logic driven). A planning document in which the dependencies and performance of events are the driving elements of the schedule, as opposed to calendar time for each event or time allowed. 
RPP-4773. Rev. 0

- Logic diagrams (to depict predecessor-successor relationships). An overview of the functions that must be performed to accomplish the mission of a program or its subprojects. The predecessor-successor relationships between the functions are depicted.

\subsection{REQUIREMENTS}

The objective of requirements is to define the technical requirement for preferred system concept in response to the customer/user needs.

- Customer/user needs and constraints. Provide the basis for top-level requirements on which a system concept is based.

- Stakeholder constraints. Top-level requirements for a program that result from basic values or interests of external organizations (e.g., native Americans, local communities, environmentalists).

- User requirements baseline. The top-level requirements, needs, or expectations established by the customer/user for a system.

- Subsystem requirements. Requirements for an identifiable part (subsystem) of the total system.

- Documentation of requirements verification criteria.

- Documentation of verification results. Provide documentary evidence on the determination of whether items, activities, processes, services, or documents conform to the requirements.

- Requirements relationships. Documentation of how and to what level requirements are related or interrelated.

- Management of changes to requirements. Control will be placed on changes made to the requirements. Requirements changes will be traceable to the source of the change. The ability of the system to meet the changed requirement will be verified.

\subsection{DESIGN}

System design includes activity planning, baseline establishment that satisfies the system requirements, ensuring that system requirements are traceable to user requirements, ensuring design rationale and other information are captured and made available within the organization, and ensuring the design is controlled and communicated to affected groups.

- Generic issue in design: Design review criteria should be available to all involved. 


\subsection{CONFIGURATION MANAGEMENT}

Configuration management is the process of identifying and defining the configuration items in a system, controlling the release and change of these items throughout the system life cycle, recording and reporting the status of configuration items and change requests, and verifying the completeness and correctness of configuration items.

- Configuration items are identified. Configuration items are a collection of hardware elements treated as a unit for the purpose of configuration management.

- Configuration items are statused. Provide recording and reporting of all changes to the configuration baseline for the life of the system or project.

- Configuration items are developed from system requirements by appropriate teams. A number of teams made up of people impacted by the system will compile configuration items.

\subsection{QUALITY MANAGEMENT}

Quality Management provides for timely and effective independent evaluation and assessment of the products and processes used to meet project objectives.

- Evaluations and assessments are reported to all affected parties. Results of evaluations and assessments are reported to all who are impacted by them.

- Evaluations and assessments are available. Results of evaluations and assessments are accessible to all that are impacted by them.

- Quality Management activities are statused for conformance to plans. All activities are recorded and reported, providing evidence of conformance to the plan for the life of the system or project.

- Documented and approved quality assurance acceptance criteria. Standards against which acceptable quality is measured are documented and approved.

\subsection{RISK INFORMATION}

Risks are described as events or factors that may affect the technical, cost, and scheduling aspects of a project in an uncertain environment.

- Cost, resource, schedule, and technical risks-identification, analysis, and mitigation. Risk Management is an organized process to identify what can go wrong; to quantify and assess the significance of the event; and to implement/control the approach for preventing, mitigating or handling each risk identified.

- Visible to Project Manager. All risk information can be seen by the project manager. 
- Risk thresholds. A subjective assessment of the amount of risk that is tolerable. When the risk threshold is exceeded. more aggressive risk mitigation efforts are required.

- Risk Management List. A risk management list is a tool used in risk management. The list contains the risks that are being tracked; the approaches selected for preventing, mitigating, or handling each risk; and the status of each item.

- Risks of different system concepts (alternatives). Risk management processes will be applied to assessments of all different system concepts and included in the overall risk information.

\subsection{TECHNICAL PERFORMANCE}

Technical performance is the accomplishment of technical parameters throughout a development project toward achieving technical objectives or requirements.

- Technical performance measures-identified, documented and distributed. Designrelated factors, preferably quantitative, that can be applied in the evaluation of a system and/or subsystems to assess and track the progress toward achieving technical objectives or requirements.

- Technical Performance Measurement Assessment Plan. A basic plan governing the assessment of the technical performance of the system. The plan describes the technical performance measures to be used and how they will be applied to the system.

- Master Measurement List. A master list of all of the technical performance measures being tracked for a program/project.

\subsection{PROJECT INFORMATION}

The various forms of documentation required to support a project in all of its areas. Data may take any form (e.g., printed or drawn on various materials, electronic media, or photographs). Data may be deliverable to a customer or nondeliverable for internal use only.

- Archiving/retrieving project information. There is a means to archive and retrieve project data.

- Relationships between requirements and interface documents (specification tree). A hierarchical depiction of the specifications needed (planned or existing) for development of the system.

- Relationships between drawings of physical elements of the system (drawing tree). A hierarchical list of drawings from a system master drawing down to individual component drawings. 
- Relationships between software elements and interfaces. Documentation will be created to describe how and to what level the software elements and interfaces are related or interrelated.

- Status of project information (at any given time). Users have the ability to obtain current pedigree of project data under data management.

\subsection{CONCURRENT ENGINEERING}

Concurrent engineering is a systematic approach to integrated, concurrent design of products and their related processes. Concurrent engineering integrates product and process requirements, organizes a program for sufficiency and effectiveness, balances the program's communication infrastructure, and integrates the systems documentation infrastructure. Marketing, engineering, manufacturing, and field support must work together to consider all elements of the product life cycle from conception through disposal to define acceptable system solutions.

- Concurrent engineering information is passed between the groups involved in concurrent engineering.

\subsection{INTERFACES}

Interfaces are described as places where two independent systems meet and act on or communication with each other.

- Interfaces identified/managed. A collection of software and hardware systems that interact or communicate with each other.

- Interface Control Document. A document, representing a design agreement between interfacing hardware or software systems, that fully defines the interface. An Interface Control Document is put under configuration control and is considered part of the baseline.

\subsection{PLANS}

Planning involves the identification of technical and programmatic requirements and constraints at the project level. These requirements define the technical and programmatic baseline.

- Technical Management Plan (Systems Engineering Management Plan). The basic plan governing the systems engineering effort. The plan describes the technical program plan and control, the systems engineering process used by the program, and how the activities of each engineering specialty are to be integrated during the program.

- Decisions/rationale recorded and traced. Determinations and reasoning for making them will be documented and monitored. 


\section{RPP-4773. Rev. 0}

- Planning and control metrics monitored/used. Measurements used to provided periodic assessments of the progress and status of a project throughout its life cycle.

Inputs/outputs of systems engineering process activities clearly identified (Project Management Plan, logic diagrams, work plans, and Systems Engineering Management Plan). A logic diagram is an overview of the functions that must be performed to accomplish the mission of a program or its subprojects. The predecessor-successor relationships between the functions are depicted. 


\subsection{MATURITY ASSESSMENT/INFORMATION CAPABILITY AND FUNCTIONALITY MATRIX}

This section provides results from the assessment process. Information needs selected for inclusion in the assessment are listed in column (A) along with their correlating assessment question numbers(see Section 4.0, "Information Capability by Information Type," and Appendix D. Column (B) includes descriptions for existing, planned, and available HANDI 2000 system provisions, as related to the coordinating information need. The information and functional system capabilities are described in columns (C) and (D), respectively. User comments on the system description and capabilities in comparison with the information needs are listed in column $(\mathrm{E})$. Column $(\mathrm{F})$ contains responses to the user comments supplied by the LMHC Systems Engineering and Integration representatives. 
Table 5-1. Maturity Assessment//nformation Capability and Functionality Matrix.

\begin{tabular}{|c|c|c|c|c|c|}
\hline (a) & (b) & (c) & (d) & (e) & (f) \\
\hline $\begin{array}{l}\text { Information Need/ } \\
\text { Question Number }\end{array}$ & $\begin{array}{l}\text { General Description of System } \\
\text { Provisions }\end{array}$ & $\begin{array}{l}\text { PHMC HANDI } 2000 \text { System } \\
\text { Information } \\
\text { Capability }\end{array}$ & $\begin{array}{l}\text { PHMC HANDI } 2000 \text { System } \\
\text { Function } \\
\text { Capability }\end{array}$ & $\begin{array}{c}\text { User Comment on PHMC } \\
\text { HANDI } 2000 \text { Capability } \\
\left({ }^{*}\right)=\text { intend to resolve with } \\
\text { Interim Stabilization Pilot } \\
\text { Project }\end{array}$ & $\begin{array}{l}\text { SE\&I Response } \\
\text { to } \\
\text { User Comment }\end{array}$ \\
\hline $\begin{array}{l}\text { 1. Program/project } \\
\text { life cycles } \\
(1.1-3.2)\end{array}$ & $\begin{array}{l}\text { HANDI } 2000 \\
\text { Projects defined in HANDI } \\
2000 \text { Project Management can } \\
\text { be set up in a hierarchy, } \\
\text { allowing rollup of projects to a } \\
\text { higher level. Thus HANDI } \\
2000 \text { Projects can be managed } \\
\text { in a manner duplicating the } \\
\text { WBS/CACN hierarchy, broken } \\
\text { down into individual projects } \\
\text { managed at the working level. } \\
\text { This allows Project } \\
\text { Management rollups of } \\
\text { estimated actual cost vs. } \\
\text { schedule at a lower level than } \\
\text { the Financial Reporting in } \\
\text { PeopleSoft } \\
\text { very ushis will be } \\
\text { manager in the field. Work } \\
\text { order task packages being } \\
\text { worked in the field will have a } \\
\text { dircct link to the project, which } \\
\text { in turn will have a direct link to } \\
\text { the higher level WBS through } \\
\text { the project hierarchy. } \\
\text { Problems with cost vs. } \\
\text { schedule at a lower work order } \\
\text { level are visible at the lower } \\
\text { levcl and at the higher project } \\
\text { level. } \\
\text { Drill down from the higher } \\
\text { level WBS to the problem } \\
\text { subproject and even to the } \\
\text { offending work order task is } \\
\text { available on-line using } \\
\text { HANDI } 2000 \text {. }\end{array}$ & $\begin{array}{l}\text { HANDI } 2000 \\
\text { - Project definition data. } \\
\text { - Project hierarchy. } \\
\text { - Project justification. } \\
\text { - Project schedule data. } \\
\text { - Project budget data. } \\
\text { - Project to work order task } \\
\text { drill down. } \\
\text { - P3 working schedule. } \\
\text { - Rollup of project } \\
\text { estimated actual cost to } \\
\text { the higher level project. } \\
\text { - AAA notification of } \\
\text { expenditure preset levels } \\
\text { at any project level. } \\
\text { - Multiple calendars for a } \\
\text { project (i.e., multi year or } \\
\text { fiscal year). } \\
\text { - Project estimated actual } \\
\text { (consolidated in } \\
\text { performance and reported } \\
\text { in HANDI 2000). } \\
\text { - P3 provides resource- } \\
\text { loaded schedules and life } \\
\text { cycle activity IDs. }\end{array}$ & $\begin{array}{l}\text { HANDI } 2000 \\
\text { AAA notification to } \\
\text { project manager based on } \\
\text { project set alarms as } \\
\text { related to percent of costs } \\
\text { and schedule. } \\
\text { - Project hierarchy. } \\
\text { - Project rollup of cost and } \\
\text { schedule to next level } \\
\text { project. } \\
\text { - Drill-down navigation to } \\
\text { all objects (e.g., action } \\
\text { items, work order tasks, } \\
\text { material requests, } \\
\text { contracts) in HANDI } 2000 \\
\text { related to a project or } \\
\text { subproject. } \\
\text { - Automatic rollup to the } \\
\text { project from Work } \\
\text { Management of estimated } \\
\text { actual cost of labor, } \\
\text { contract labor, and } \\
\text { materials on work order } \\
\text { tasks associated to a } \\
\text { project. } \\
\text { - Linkage of contracts to } \\
\text { project activities and } \\
\text { automatic update of } \\
\text { project as to contract costs } \\
\text { to date. }\end{array}$ & $\begin{array}{l}\left.\text { - }{ }^{*}\right) \text { Need to develop Labor } \\
\text { Entry and TIS relationship } \\
\text { to ensure project } \\
\text { information can be } \\
\text { retrieved when needed. } \\
\text { - Need to establish P3 links } \\
\text { to input project cost and } \\
\text { schedule budget } \\
\text { information. Budget } \\
\text { information is essential for } \\
\text { comparisons. } \\
\\
\\
\text { - Multi-year projects need } \\
\text { additional development to } \\
\text { handle the DOE single-year } \\
\text { budget/multi-year plan if } \\
\text { this is to be a major project } \\
\text { tool. }\end{array}$ & $\begin{array}{l}\text { - The relationship of Work } \\
\text { Management Labor Entry to } \\
\text { Business Management Labor } \\
\text { Entry (TIS) is assumed in the } \\
\text { scope of this assessment. } \\
\text { - We prefer to manage cost or } \\
\text { schedule through integrated } \\
\text { HANDI } 2000 \text { database and } \\
\text { regenerate the P3 data files as } \\
\text { needed. In other words, we } \\
\text { use P3 for development and } \\
\text { "what if," but use the Project } \\
\text { Management module for } \\
\text { baseline control and } \\
\text { integration. } \\
\text { - See Recommendation } 7.1 \text {. }\end{array}$ \\
\hline
\end{tabular}


Table 5-1. Maturity Assessment/Information Capability and Functionality Matrix.

\begin{tabular}{|c|c|c|c|c|c|}
\hline (a) & (b) & (c) & (d) & (e) & (f) \\
\hline \multirow[t]{2}{*}{$\begin{array}{l}\text { Information Need / } \\
\text { Question Number }\end{array}$} & $\begin{array}{c}\text { General Description of System } \\
\text { Provisions }\end{array}$ & $\begin{array}{l}\text { PHMC HANDI } 2000 \text { System } \\
\text { Information } \\
\text { Capability }\end{array}$ & $\begin{array}{l}\text { PHMC HANDI } 2000 \text { System } \\
\text { Function } \\
\text { Capability }\end{array}$ & $\begin{array}{l}\text { User Comment on PHMC } \\
\text { HANDI } 2000 \text { Capability } \\
\left({ }^{*}\right)=\text { intend to resolve with } \\
\text { Interim Stabilization Pilot } \\
\text { Project }\end{array}$ & $\begin{array}{l}\text { SE\&I Response } \\
\text { to } \\
\text { User Comment }\end{array}$ \\
\hline & $\begin{array}{l}\text { HANDI has the capability to } \\
\text { drill down to the level of } \\
\text { information provided. } \\
\text { PeopleSoft }{ }^{\mathrm{TM}} \text { has the capability } \\
\text { to track and roll up costs at any } \\
\text { hierarchical level. } \\
\text { PeopleSoff }{ }^{\mathrm{TM}} \text { provides a robust } \\
\text { reporting capability with on- } \\
\text { line query tools. }\end{array}$ & & & 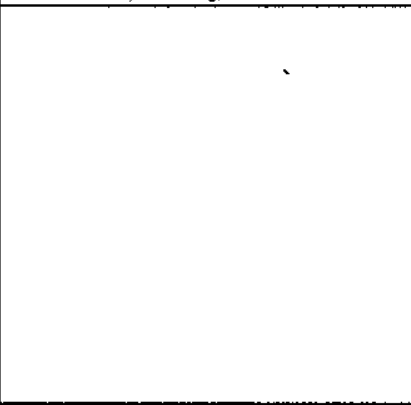 & 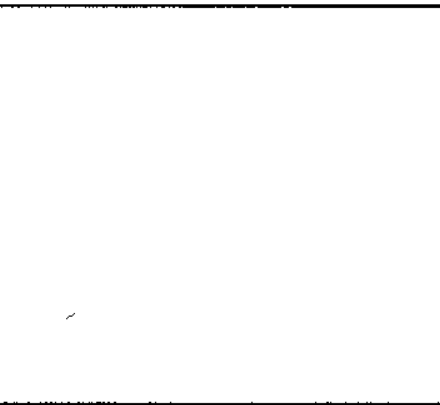 \\
\hline $\begin{array}{l}\text { 2. Work breakdown } \\
\text { structure } \\
(1.1-1.3)\end{array}$ & $\begin{array}{l}\text { HANDI } 2000 \\
\text { Projects defined in the HANDI } \\
2000 \text { Project Management } \\
\text { system are made up of } \\
\text { summary tasks. Each summary } \\
\text { task may be assigned to an } \\
\text { accounting activity. (Activities } \\
\text { in HANDI } 2000 \text { are mapped to } \\
\text { CACN from PeopleSoft } \\
\text { financials.) These activities } \\
\text { may be associated with other } \\
\text { HANDI } 2000 \text { objects such as } \\
\text { contracts, work orders, and } \\
\text { material requests that also may } \\
\text { be charged to one or multiple } \\
\text { (by percentage) accounts. } \\
\text { Progress against the work plan } \\
\text { and cost plan can be monitored } \\
\text { at any point in the project life } \\
\text { cycle. This is accomplished } \\
\text { through integration with the } \\
\text { following HANDI } 2000 \\
\text { products: } \\
\text { - Accounts Payable } \\
\text { - Action Tracking } \\
\text { - Contract Management } \\
\end{array}$ & $\begin{array}{l}\text { HANDI } 2000 \\
\text { - WBS structure. } \\
\text { - Description. } \\
\text { - Financial data. } \\
\text { - Purchases. } \\
\text { - Resources. } \\
\text { - Project definition data. } \\
\text { - Project justification. } \\
\text { - Project schedule data. } \\
\text { - Project budget data. } \\
\text { - Project level rollup of } \\
\text { costs (e.g., labor, } \\
\text { material, contract labor). } \\
\text { - Task field package rollup } \\
\text { of costs (e.g., labor, } \\
\text { material, contract labor). } \\
\text { - Schedule (Work } \\
\text { Management work order } \\
\text { integration with P3 } \\
\text { schedules). }\end{array}$ & $\begin{array}{l}\text { HANDI } 2000 \\
\text { - Rejects changes to WBS } \\
\text { without associated BCR } \\
\text { number } \\
\text { - AAA notification to } \\
\text { project manager based on } \\
\text { project set alarms as } \\
\text { related to percent of costs } \\
\text { and schedule. } \\
\text { - Automatic rollup to the } \\
\text { project from Work } \\
\text { Management of estimated } \\
\text { actual cost of labor, } \\
\text { contract labor, and } \\
\text { materials on work order } \\
\text { tasks associated to a } \\
\text { project. } \\
\text { - Linkage of Contracts to } \\
\text { Project Activities and } \\
\text { automatic update of } \\
\text { project as to contract costs } \\
\text { to date. } \\
\text { Batch interface from the } \\
\text { HANDI } 2000 \text { Project } \\
\text { Management module to } \\
\text { Microsoft Project } \\
\text { scheduling tool. }\end{array}$ & $\begin{array}{l}\text { Accrual information does } \\
\text { not match with reporting } \\
\text { requirements. This } \\
\text { situation drives inherent } \\
\text { errors in reporting and } \\
\text { continues to require manual } \\
\text { input. }\end{array}$ & $\begin{array}{l}\text { The system recognizes } \\
\text { Purchasing } \\
\text { commitments/plans and labor } \\
\text { plans. Contract labor accruals } \\
\text { are captured as frequently as } \\
\text { needed (e.g., daily) using the } \\
\text { same transactions as employee } \\
\text { labor. The Project } \\
\text { Management system is } \\
\text { intended to provide project } \\
\text { managers with real-time status } \\
\text { information. It does this by } \\
\text { estimating the actual cost of } \\
\text { transactions. The timing of } \\
\text { project transactions and } \\
\text { financial transactions differ } \\
\text { greatly (e.g., labor may not be } \\
\text { billed by contractors for up to } \\
2 \text { months after it is actually } \\
\text { worked). For this reason, the } \\
\text { probability of reconciling } \\
\text { project costs on a regular basis } \\
\text { is impractical. Spot audits } \\
\text { offer a better solution to } \\
\text { ensure that the project status } \\
\text { information quality is } \\
\text { acceptable. }\end{array}$ \\
\hline
\end{tabular}

\footnotetext{
${ }^{5}$ Microsoft Project is a trademark of Microsoft Corporation, Redmond, Washington.
} 
Table 5-1. Maturity Assessment/Information Capability and Functionality Matrix.

\begin{tabular}{|c|c|c|c|c|c|}
\hline (a) & (b) & (c) & (d) & (e) & (f) \\
\hline $\begin{array}{l}\text { Information Need/ } \\
\text { Question Number }\end{array}$ & $\begin{array}{c}\text { General Description of System } \\
\text { Provisions }\end{array}$ & $\begin{array}{l}\text { PHMC HANDI } 2000 \text { System } \\
\text { Information } \\
\text { Capability }\end{array}$ & $\begin{array}{l}\text { PHMC HANDI } 2000 \text { System } \\
\text { Function } \\
\text { Capability }\end{array}$ & $\begin{array}{c}\text { User Comment on PHMC } \\
\text { HANDI } 2000 \text { Capability } \\
(*)=\text { intend to resolve with } \\
\text { Interim Stabilization Pilot } \\
\text { Project }\end{array}$ & $\begin{array}{c}\text { SE\&I Response } \\
\text { to } \\
\text { User Comment }\end{array}$ \\
\hline . & $\begin{array}{l}\text { - Document Management } \\
\text { - Inventory Management } \\
\text { - Labor Entry and Reporting } \\
\text { - Purchasing } \\
\text { - Work Management } \\
\text { Outstanding financial } \\
\text { commitments and incurred } \\
\text { costs (estimated actuals) are } \\
\text { tracked (real time) in HANDI } \\
2000 \text { Project Management from } \\
\text { those activities that are } \\
\text { recorded in other HANDI } 2000 \\
\text { modules. Project cost variance } \\
\text { supports the review of budget } \\
\text { vs. forecast. Actual costs are } \\
\text { separately totaled in } \\
\text { PeopleSoftTM based on } \\
\text { WBS/CACN/COA. } \\
\text { Official WBS down to the } \\
\text { function level is provided in } \\
\text { HSTD. The projccts then break } \\
\text { down their work until they } \\
\text { reach a levcl of work they can } \\
\text { track progress against. CACN } \\
\text { can be assigned to this level to } \\
\text { track and collect costs. } \\
\text { Accurate tracking of costs can } \\
\text { be accomplished at this level. } \\
\text { PeopleSoft } \\
\text { at track has the capability at any } \\
\text { hierarchical level. Costs can be } \\
\text { rolled up at any level. } \\
\text { PeopleSof } \mathrm{T}^{\mathrm{TM}} \text { provides for a } \\
\text { robust reporting capability with } \\
\text { on-line query tools. P3 can roll } \\
\text { up and report BCWS or PCWP } \\
\text { to any level of the WBS. } \\
\text { HANDI } 2000 \text { also has point- }\end{array}$ & & $\begin{array}{l}\text { - Ability to define and save } \\
\text { cost and schedule } \\
\text { scenarios for a project and } \\
\text { to proceed with the } \\
\text { selected plan. } \\
\text { - So-called "white collar" } \\
\text { work can be assigned to } \\
\text { the worker via an action } \\
\text { tracking assignment. If } \\
\text { the assignment is related to } \\
\text { the project, labor hours } \\
\text { against the assignment } \\
\text { reported in Labor Entry } \\
\text { can be rolled up as part of } \\
\text { the estimated actual costs } \\
\text { against the project. } \\
\text { - Project plans may be } \\
\text { submitted for approval } \\
\text { using the standard HANDI } \\
\text { 2000 routing features } \\
\text { using AAA messages to } \\
\text { notify the project initiator } \\
\text { if the package has been } \\
\text { rejected or returned. } \\
\text { - Supports the creation and } \\
\text { approval routing of an } \\
\text { authorization for } \\
\text { expenditure. }\end{array}$ & $\begin{array}{l}\text { - Burdens and taxes } \\
\text { associated with } \\
\text { procurements and contract } \\
\text { labor are not accrued with } \\
\text { the commitment and labor } \\
\text { transactions. This could } \\
\text { affect a project's estimated } \\
\text { actual accuracy. Monthly } \\
\text { flow down assessments are } \\
\text { not accrued, but these do } \\
\text { not normally affect } \\
\text { individual projects. } \\
\text { - Accumulation of costs } \\
\text { against a project needs to } \\
\text { be available whether the } \\
\text { labor-entry module is } \\
\text { implemented or not. } \\
\text { Project requirements are for } \\
\text { collection of actual cost } \\
\text { information for comparison } \\
\text { against budget. } \\
\text { - Need to have a clearly } \\
\text { defined set of labor rates to } \\
\text { estimate with. }\end{array}$ & $\begin{array}{l}\text { - The burdens will need to be } \\
\text { added to the project cost. The } \\
\text { frequency requirement for this } \\
\text { process affects the design } \\
\text { requirements and will be } \\
\text { determined under the HANDI } \\
2000 \text { project scope. With this } \\
\text { issue resolved, the estimated } \\
\text { actuals are accurate enough } \\
\text { for managing day-to-day } \\
\text { progress and making business } \\
\text { decisions. } \\
\text { - The decision to implement the } \\
\text { Labor module has been } \\
\text { confirmed; this is not an issue. } \\
\\
\text { This is a management issue. } \\
\text { The system will handle } \\
\text { correctly. }\end{array}$ \\
\hline
\end{tabular}


Table 5-1. Maturity Assessment/Information Capability and Functionality Matrix.

\begin{tabular}{|c|c|c|c|c|c|}
\hline (a) & (b) & (c) & (d) & (e) & (f) \\
\hline \multirow[t]{2}{*}{$\begin{array}{l}\text { Information Need/ } \\
\text { Question Number }\end{array}$} & $\begin{array}{l}\text { General Description of System } \\
\text { Provisions }\end{array}$ & $\begin{array}{l}\text { PHMC HANDI } 2000 \text { System } \\
\text { Information } \\
\text { Capability }\end{array}$ & $\begin{array}{l}\text { PHMC HANDI } 2000 \text { System } \\
\text { Function } \\
\text { Capability }\end{array}$ & $\begin{array}{c}\text { User Comment on PHMC } \\
\text { HANDI } 2000 \text { Capability } \\
\left({ }^{*}\right)=\text { intend to resolve with } \\
\text { Interim Stabilization Pilot } \\
\text { Project }\end{array}$ & $\begin{array}{l}\text { SE\&I Response } \\
\text { to } \\
\text { User Comment }\end{array}$ \\
\hline & $\begin{array}{l}\text { and-click drill-down capability } \\
\text { to a level of the WBS to track } \\
\text { budget performance, actual } \\
\text { cost, and commitments. }\end{array}$ & & & & \\
\hline $\begin{array}{l}\text { 3. Event-driven plan } \\
\text { (activity based or } \\
\text { logic driven) } \\
(1.1-3.3)\end{array}$ & $\begin{array}{l}\text { HANDI } 2000 \\
\text { HANDI 2000 provides two } \\
\text { levels of work planning. } \\
\text { At the project level, the project } \\
\text { is broken down into scheduled } \\
\text { activities. HANDI } 2000 \\
\text { provides a batch interface to the } \\
\text { Microsoft Project'T scheduling } \\
\text { tool. To use the interface, } \\
\text { resource and calendar setup in } \\
\text { Microsoft ProjectTM must } \\
\text { match the HANDI } 2000 \text { project } \\
\text { sctup. HANDI } 2000 \text { project } \\
\text { summary task data are passed } \\
\text { through the interface to } \\
\text { Microsoft Project }{ }^{\mathrm{T} M} \text {. } \\
\text { Scheduling of the project } \\
\text { summary tasks is performed in } \\
\text { the scheduling tool. Schedule } \\
\text { dates are passed back to } \\
\text { HANDI } 2000 \text { so that the } \\
\text { activities show the dates as } \\
\text { scheduled in Microsoft } \\
\text { Projcct } \mathrm{TM} \text {. Project progress is } \\
\text { input to HANDI } 2000 \text { and } \\
\text { passed through the interface to } \\
\text { P3 where rescheduling occurs } \\
\text { as necessary. The cycle repeats } \\
\text { as many times as necessary } \\
\text { until the project is completed. } \\
\text { Project schedule vs. estimated } \\
\text { actual cost is tracked in } \\
\text { HANDI } 2000 \text { Project } \\
\text { Management. }\end{array}$ & $\begin{array}{l}\text { HANDI } 2000 \\
\text { - Project definition data. } \\
\text { - Project hierarchy. } \\
\text { - Project schedule data. } \\
\text { - Project budget data. } \\
\text { - Project to work order task } \\
\text { drill down. } \\
\text { - HANDI } 2000 \text { Project } \\
\text { Management to Microsoft } \\
\text { Project'T interface. } \\
\text { - HANDI } 2000 \text { Work } \\
\text { Management to Microsoft } \\
\text { Project'TM interface. } \\
\text { - HANDI } 2000 \text { Work } \\
\text { Management to P3 } \\
\text { interface. } \\
\text { - Rollup of project } \\
\text { estimated actual costs and } \\
\text { schedule information to } \\
\text { the higher level project. } \\
\text { - AAA notification of } \\
\text { expenditure preset levels } \\
\text { at any project level. }\end{array}$ & $\begin{array}{l}\text { HANDI } 2000 \\
\text { - HANDI } 2000 \text { project } \\
\text { batch interface with } \\
\text { Microsoft Project } \\
\text { - HANDI } 2000 \text { Work } \\
\text { Management batch } \\
\text { interface with P3. } \\
\text { - HANDI } 2000 \text { Work } \\
\text { Management batch } \\
\text { interface with Microsoft } \\
\text { Project' }{ }^{\mathrm{TM}} \text {. } \\
\text { - Ability to sort and select } \\
\text { work order tasks to be sent } \\
\text { through the batch interface } \\
\text { to Microsoft Project } \\
\text { P3. } \\
\text { - Project hierarchy and } \\
\text { rollup of cost and schedule } \\
\text { to the next level project. } \\
\text { - Drill-down navigation to } \\
\text { all objects (e.g., action } \\
\text { items, work order tasks, } \\
\text { material requests, } \\
\text { contracts) in HANDI } 2000 \\
\text { related to a project or } \\
\text { subproject. }\end{array}$ & $\begin{array}{l}\text { (*)Interface between P3 } \\
\text { and HANDI } 2000 \text { Project } \\
\text { Management needs to be } \\
\text { created. Without an } \\
\text { interface, Project Control } \\
\text { loses significant } \\
\text { effectiveness. Present } \\
\text { intent would be to develop } \\
\text { schedule using P3, or } \\
\text { perhaps Microsoft } \\
\text { Projectrim. for small work } \\
\text { tasks, and import as the } \\
\text { cost/schedule basis. } \\
\text { Without this capability, the } \\
\text { Project Management } \\
\text { module loses viability. }\end{array}$ & $\begin{array}{l}\text { See Recommendation 7.1. } \\
\text { Comments also apply to } \\
\text { Microsoft Project }\end{array}$ \\
\hline
\end{tabular}


Table 5-1. Maturity Assessment/Information Capability and Functionality Matrix.

\begin{tabular}{|c|c|c|c|c|c|}
\hline (a) & (b) & (c) & (d) & (e) & (f) \\
\hline $\begin{array}{l}\text { Information Need/ } \\
\text { Question Number }\end{array}$ & $\begin{array}{c}\text { General Description of System } \\
\text { Provisions }\end{array}$ & $\begin{array}{l}\text { PHMC HANDI } 2000 \text { System } \\
\text { Information } \\
\text { Capability }\end{array}$ & $\begin{array}{l}\text { PHMC HANDI } 2000 \text { System } \\
\text { Function } \\
\text { Capability }\end{array}$ & $\begin{array}{l}\text { User Comment on PHMC } \\
\text { HANDI } 2000 \text { Capability } \\
\left({ }^{*}\right)=\text { intend to resolve with } \\
\text { Interim Stabilization Pilot } \\
\text { Project }\end{array}$ & $\begin{array}{l}\text { SE\&I Response } \\
\text { to } \\
\text { User Comment }\end{array}$ \\
\hline & $\begin{array}{l}\text { At the work package level, } \\
\text { work order tasks may be } \\
\text { scheduled in HANDI } 2000 \text { or a } \\
\text { batch interface to Microsoft } \\
\text { Project } \\
\text { pass or P3 may be used to } \\
\text { as activities to the scheduling } \\
\text { tool. Daily progress is sent to } \\
\text { the scheduling tool via the use } \\
\text { of the batch interface. To use } \\
\text { the interface, resource and } \\
\text { calendar setup in Microsoft } \\
\text { Project' } \\
\text { the HANDI } \text { P3) must match } \\
\text { functionality is primarily used } \\
\text { as a daily scheduling tool at the } \\
\text { working level. HANDI } 2000 \\
\text { projects can be set up in a } \\
\text { hierarchy with the lowest level } \\
\text { controlled at the work order } \\
\text { task level. } \\
\text { P3 is currently the tool used to } \\
\text { identify, schedule, and budget } \\
\text { work at the Hanford Site. P3 } \\
\text { allows for activity scheduling } \\
\text { at any level. P3 is activity- } \\
\text { based, logic-driven, and } \\
\text { resource-loaded. P3 is the tool } \\
\text { used to create the BCWS and } \\
\text { track the BCWP. } \\
\text { P3 has capabilitics available to } \\
\text { track budget and performance } \\
\text { data, calculate estimatc-to- } \\
\text { complete costs, assign work to } \\
\text { different calendars, provide } \\
\text { resource information, and } \\
\text { provide various graphics. }\end{array}$ & & - & . & \\
\hline
\end{tabular}


Table 5-1. Maturity Assessment/Information Capability and Functionality Matrix.

\begin{tabular}{|c|c|c|c|c|c|}
\hline (a) & (b) & (c) & (d) & (e) & $(f)$ \\
\hline $\begin{array}{l}\text { Information Need./ } \\
\text { Question Number }\end{array}$ & $\begin{array}{c}\text { General Description of System } \\
\text { Provisions }\end{array}$ & $\begin{array}{l}\text { PHMC HANDI } 2000 \text { System } \\
\text { Information } \\
\text { Capability }\end{array}$ & $\begin{array}{l}\text { PHMC HANDI } 2000 \text { System } \\
\text { Function } \\
\text { Capability }\end{array}$ & $\begin{array}{c}\text { User Comment on PHMC } \\
\text { HANDI } 2000 \text { Capability } \\
\left({ }^{*}\right)=\text { intend to resolve with } \\
\text { Interim Stabilization Pilot } \\
\text { Project }\end{array}$ & $\begin{array}{l}\text { SE\&I Response } \\
\text { to } \\
\text { User Comment }\end{array}$ \\
\hline $\begin{array}{l}\text { 4. Logic diagrams } \\
\text { (to depict } \\
\text { predecessor- } \\
\text { successor } \\
\text { relationships) } \\
(3.5-4.3)\end{array}$ & $\begin{array}{l}\text { HANDI } 2000 \\
\text { See item 3. (Logic is depicted } \\
\text { in P3 schedule.) }\end{array}$ & $\begin{array}{l}\text { HANDI } 2000 \\
\text { See item 3. (Logic is } \\
\text { depicted in P3 schedule.) }\end{array}$ & $\begin{array}{l}\text { HANDI 2000 } \\
\text { See item 3. (Logic is } \\
\text { depicted in P3 schedule.) }\end{array}$ & $\begin{array}{l}\text { Project logics are also } \\
\text { maintained in drawings that } \\
\text { cannot be configuration } \\
\text { managed and release } \\
\text { controlled in the } \\
\text { HANDI } 2000 \text { system. }\end{array}$ & - See Recommendation 7.4. \\
\hline $\begin{array}{l}\text { 5. } \begin{array}{l}\text { Customer/user } \\
\text { needs and }\end{array} \\
\text { constraints } \\
(3.1-1.3,3.1-2.4)\end{array}$ & $\begin{array}{l}\text { HANDI } 2000 \\
\text { HANDI } 2000 \text { customer/user } \\
\text { needs and constraints data may } \\
\text { be defined on the Project } \\
\text { Information under Notes, or as } \\
\text { a separate document listed on } \\
\text { the Justification panel. Several } \\
\text { combinations of budget and } \\
\text { schedule may be developed for } \\
\text { a project. All scenarios are } \\
\text { kept for history. One } \\
\text { budget/schedule combination is } \\
\text { selected for implementation. }\end{array}$ & $\begin{array}{l}\text { HANDI } 2000 \\
\text { - } \text { WBS structure. } \\
\text { - } \text { Description. } \\
\text { - Purchancial data. } \\
\text { - Resources. } \\
\text { - Project definition data. } \\
\text { - Project justification. } \\
\text { - Project schedule data. } \\
\text { - Project budget data. } \\
\text { - Project level rollup of } \\
\text { costs (e.g., labor, } \\
\text { material, contract labor). } \\
\text { - Task field package rollup } \\
\text { of costs (e.g., labor, } \\
\text { material, contract labor). } \\
\text { - Schedule (Work } \\
\text { Management work order } \\
\text { integration with P3 } \\
\text { schedules). . }\end{array}$ & $\begin{array}{l}\text { HANDI } 2000 \\
\text { - Rejects changes to WBS } \\
\text { without associated BCR } \\
\text { number. } \\
\text { - AAA notification to } \\
\text { project manager based on } \\
\text { project set alarms as } \\
\text { related to percent of costs } \\
\text { and schedule. } \\
\text { - Automatic rollup to the } \\
\text { project from Work } \\
\text { Management of estimated } \\
\text { actual cost of labor, } \\
\text { contract labor, and } \\
\text { materials on work order } \\
\text { tasks associated to a } \\
\text { project. } \\
\text { - Linkage of contracts to } \\
\text { project activities and } \\
\text { automatic update of } \\
\text { project as to contract costs } \\
\text { to date. } \\
\text { - Batch interface from the } \\
\text { HANDI } 2000 \text { Project } \\
\text { Management module to } \\
\text { Microsoft Project } \\
\text { scheduling tool. } \\
\text { - Ability to define and save } \\
\text { cost and schedule } \\
\text { scenarios for a project and } \\
\text { to proceed with the } \\
\text { selected plan. } \\
\text { So-called "white collar" }\end{array}$ & $\begin{array}{l}\text { - }{ }^{*} \text { ) Interface between P3 } \\
\text { and HANDI } 2000 \text { Project } \\
\text { Management needs to be } \\
\text { created. Without an } \\
\text { interface, Project Control } \\
\text { loses significant } \\
\text { effectiveness. } \\
\text { - Need to change DOE } \\
\text { reporting requirements to } \\
\text { give information in a } \\
\text { format that allows the } \\
\text { system to generate the } \\
\text { report without } \\
\text { manipulation by people } \\
\text { interfaces (i.e., cost } \\
\text { variance, spend variance, } \\
\text { and schedule variance } \\
\text { reports). } \\
\text { Need to have "white collar" } \\
\text { labor able to be assigned } \\
\text { directly to project without } \\
\text { being assigned to Action } \\
\text { Tracking or Work Control } \\
\text { modules. }\end{array}$ & $\begin{array}{l}\text { - See Recommendation 7.1. } \\
\text { - Will work with DOE-ORP to } \\
\text { obtain concurrence to the } \\
\text { benefit of all parties (LMHC, } \\
\text { FDH, and DOE). Access to } \\
\text { electronic data for user } \\
\text { manipulation will be provided. } \\
\text { - This capability requires } \\
\text { customization of the HANDI } \\
\text { 2000 COTS software } \\
\text { products, which creates a } \\
\text { continuous life-cycle negative } \\
\text { impact on maintenance costs. } \\
\text { Measured against this cost, the } \\
\text { use of work orders and actions } \\
\text { are the preferred approach. } \\
\text { See Recommendation } 7.2 \text {. }\end{array}$ \\
\hline
\end{tabular}


Table 5-1. Maturity Assessment/Information Capability and Functionality Matrix.

\begin{tabular}{|c|c|c|c|c|c|}
\hline (a) & (b) & (c) & (d) & (e) & (f) \\
\hline $\begin{array}{l}\text { Information Need/ } \\
\text { Question Number }\end{array}$ & $\begin{array}{c}\text { General Description of System } \\
\text { Provisions }\end{array}$ & $\begin{array}{l}\text { PHMC HANDI } 2000 \text { System } \\
\text { Information } \\
\text { Capability }\end{array}$ & $\begin{array}{l}\text { PHMC HANDI } 2000 \text { System } \\
\text { Function } \\
\text { Capability }\end{array}$ & $\begin{array}{c}\text { User Comment on PHMC } \\
\text { HANDI } 2000 \text {. Capability } \\
\left(^{*}\right)=\text { intend to resolve with } \\
\text { Interim Stabilization Pilot } \\
\text { Project }\end{array}$ & $\begin{array}{c}\text { SE\&I Response } \\
\text { to } \\
\text { User Comment }\end{array}$ \\
\hline & & & $\begin{array}{l}\text { work can be assigned to } \\
\text { the worker via an action } \\
\text { tracking assignment. If } \\
\text { the assignment is related to } \\
\text { the project, labor hours } \\
\text { against the assignment } \\
\text { reported in Labor Entry } \\
\text { can be rolled up as part of } \\
\text { the estimated actual costs } \\
\text { against the project. } \\
\text { - Project plans may be } \\
\text { submitted for approval } \\
\text { using the standard } \\
\text { HANDI } 2000 \text { routing } \\
\text { features using AAA } \\
\text { messages to notify the } \\
\text { project initiator if the } \\
\text { package has been rejected } \\
\text { or returned. } \\
\text { - Supports the creation and } \\
\text { approval routing of an } \\
\text { authorization for } \\
\text { expenditure. }\end{array}$ & $\begin{array}{l}\text { The linkage between } \\
\text { HANDI } 2000 \text { and the } \\
\text { baseline must be } \\
\text { developed. } \\
\text { - HANDI } 2000 \text { does not } \\
\text { provide user requirements } \\
\text { and constraint } \\
\text { configuration management, } \\
\text { document release control, } \\
\text { document markup and } \\
\text { annotation, or broad (non- } \\
\text { serial) review and approval } \\
\text { routing. It does provide for } \\
\text { manual entry of control and } \\
\text { status information. } \\
\text { However, documents can } \\
\text { be accessed, modified, and } \\
\text { approved outside the } \\
\text { control of Document } \\
\text { Management. }\end{array}$ & - See Recommendation 7.4 . \\
\hline $\begin{array}{l}\text { 6. Stakeholder } \\
\text { constraints } \\
(3.2-1.4)\end{array}$ & $\begin{array}{l}\text { HANDI } 2000 \\
\text { Stakeholder constraints data } \\
\text { may be defined on the Project } \\
\text { Information under Notes or as a } \\
\text { separate document listed on the } \\
\text { Justification pancl. } \\
\text { If the stakcholder constraints } \\
\text { are contained in specific } \\
\text { controlled documents or } \\
\text { records, these documents may } \\
\text { be listed as document } \\
\text { references under Project } \\
\text { Information. }\end{array}$ & $\begin{array}{l}\text { HANDI 2000 } \\
\text { OLE link to a Microsoft } \\
\text { Word document or } \\
\text { Microsoft } \\
\text { spreadsheet. Excel }\end{array}$ & $\begin{array}{l}\text { HANDI } 2000 \\
\text { - Ability to OLE link to a } \\
\text { document. } \\
\text { - Project Management/Work } \\
\text { Management allows } \\
\text { management of OLE- } \\
\text { linked document. } \\
\text { - Document is visible to } \\
\text { appropriate parties. }\end{array}$ & $\begin{array}{l}\text { Document Management } \\
\text { module is necessary to tie } \\
\text { these requirements to the } \\
\text { project. If the Document } \\
\text { Management is not yet } \\
\text { implemented, document } \\
\text { references may still be } \\
\text { listed against the Project } \\
\text { Information. The } \\
\text { functionality that will not } \\
\text { be available is the control } \\
\text { of these documents and the } \\
\text { ability to link directly to the } \\
\text { document image or to the } \\
\text { OLE-linked document. }\end{array}$ & $\begin{array}{l}\text { This module is owned and will } \\
\text { be planned for FY } 2000 \\
\text { implementation. We will be } \\
\text { able to implement a link to } \\
\text { HSTD through Project } \\
\text { Management. The Document } \\
\text { Management module is not } \\
\text { necessary to list controlled } \\
\text { document rcferences and } \\
\text { records (letters) that contain } \\
\text { requirements. Document } \\
\text { Management is required, } \\
\text { however, to allow the user to } \\
\text { navigate from the documents } \\
\text { listed to the actual documents }\end{array}$ \\
\hline
\end{tabular}

${ }^{6}$ Microsoft is a trademark of the Microsoft Corporation, Redmond, Washington. 
Table 5-1. Maturity Assessment/Information Capability and Functionality Matrix.

\begin{tabular}{|c|c|c|c|c|c|}
\hline (a) & (b) & (c) & (d) & (e) & (f) \\
\hline $\begin{array}{l}\text { Information Need / } \\
\text { Question Number }\end{array}$ & $\begin{array}{c}\text { General Description of System } \\
\text { Provisions }\end{array}$ & $\begin{array}{l}\text { PHMC HANDI } 2000 \text { System } \\
\text { Information } \\
\text { Capability }\end{array}$ & $\begin{array}{l}\text { PHMC HANDI } 2000 \text { System } \\
\text { Function } \\
\text { Capability }\end{array}$ & $\begin{array}{c}\text { User Comment on PHMC } \\
\text { HANDI } 2000 \text { Capability } \\
\left({ }^{*}\right)=\text { intend to resolve with } \\
\text { Interim Stabilization Pilot } \\
\text { Project }\end{array}$ & $\begin{array}{c}\text { SE\&I Rèsponse } \\
\text { to } \\
\text { User Comment }\end{array}$ \\
\hline & $\begin{array}{l}\text { HANDI } 2000 \text { has limited } \\
\text { capability to link to various } \\
\text { programs containing project } \\
\text { data. }\end{array}$ & . & & $\begin{array}{l}\text { Documents are not the } \\
\text { origin of stakeholder } \\
\text { constraints. Most RPP } \\
\text { stakeholder product and } \\
\text { service constraints are } \\
\text { currently stored in S/RIDS } \\
\text { but are planned to be } \\
\text { moved to the HSTD. The } \\
\text { linkage between } \\
\text { HAND } 2000 \text { and HSTD } \\
\text { requirements/constraints } \\
\text { must be developed. } \\
\text { HANDI } 2000 \text { does not } \\
\text { provide constraint } \\
\text { configuration management, } \\
\text { document release control, } \\
\text { document markup and } \\
\text { annotation, or broad (non- } \\
\text { serial) review and approval } \\
\text { routing. It does provide for } \\
\text { manual entry of control and } \\
\text { status information. } \\
\text { However, documents can } \\
\text { be accessed, modified, and } \\
\text { approved outside the } \\
\text { control of Document } \\
\text { Management. }\end{array}$ & $\begin{array}{l}\text { (imaged or OLE linked). } \\
\text { See Recommendation } 7.2 \text {. } \\
\text { See Recommendations } 7.4 \\
\text { and } 7.5 \text {. }\end{array}$ \\
\hline $\begin{array}{l}\text { 7. User requirements } \\
\text { baseline } \\
(3.2-1.4)\end{array}$ & $\begin{array}{l}\text { HANDI } 2000 \\
\text { User requirements baseline } \\
\text { data may be defined on the } \\
\text { Project Information under Note } \\
\text { or as a separate document listed } \\
\text { on the Justification panel. }\end{array}$ & $\begin{array}{l}\text { HANDI } 2000 \\
\text { OLE link to a } \\
\text { Microsoft } \\
\text { document or Microsoft } \\
\text { Excel spreadsheet. }\end{array}$ & $\begin{array}{l}\text { HANDI 2000 } \\
\text { Ability to OLE link to a } \\
\text { document. } \\
\text { - Project Management } \\
\text { /Work Management allows } \\
\text { management of OLE- } \\
\text { linked document. } \\
\text { Document is visible to } \\
\text { appropriate parties. }\end{array}$ & $\begin{array}{l}\text { Requirement types and } \\
\text { sources need to be more } \\
\text { clearly communicated } \\
\text { down through the } \\
\text { organization (i.e., should } \\
\text { not need an HSTD expert } \\
\text { in each organization). } \\
\text { RPP user/customer product } \\
\text { and requirements currently } \\
\text { are stored in the HSTD as } \\
\text { well as guidance and } \\
\text { agreement documents, (i.e., } \\
\text { the project baseline). The }\end{array}$ & $\begin{array}{l}\text { We will plan an FY } 2000 \\
\text { activity to make a HSTD } \\
\text { interface user friendly and } \\
\text { available to all requirement } \\
\text { owners. } \\
\text { - See Recommendation } 7.2 \text {. }\end{array}$ \\
\hline
\end{tabular}


Table 5-1. Maturity Assessment/Information Capability and Functionality Matrix.

\begin{tabular}{|c|c|c|c|c|c|}
\hline (a) & (b) & (c) & (d) & (e) & (f) \\
\hline $\begin{array}{l}\text { Information Need/ } \\
\text { Question Number }\end{array}$ & $\begin{array}{l}\text { General Description of System } \\
\text { Provisions }\end{array}$ & $\begin{array}{l}\text { PHMC HANDI } 2000 \text { System } \\
\text { Information } \\
\text { Capability }\end{array}$ & $\begin{array}{l}\text { PHMC HANDI } 2000 \text { System } \\
\text { Function } \\
\text { Capability }\end{array}$ & $\begin{array}{l}\text { User Comment on PHMC } \\
\text { HANDI } 2000 \text { Capability } \\
\left({ }^{*}\right)=\text { intend to resolve with } \\
\text { Interim Stabilization Pilot } \\
\text { Project }\end{array}$ & $\begin{array}{l}\text { SE\&I Response } \\
\text { to } \\
\text { User Comment }\end{array}$ \\
\hline . & & & & $\begin{array}{l}\text { linkage between HANDI } \\
2000 \text { and the baseline must } \\
\text { be developed. } \\
\text { - HANDI } 2000 \text { does not } \\
\text { provide requirements } \\
\text { configuration management, } \\
\text { document release control, } \\
\text { configuration management, } \\
\text { document markup and } \\
\text { annotation, or broad (non- } \\
\text { serial) review and approval } \\
\text { routing. }\end{array}$ & $\begin{array}{l}\text { - See Recommendations } 7.4 \text { and } \\
7.5 \text {. }\end{array}$ \\
\hline $\begin{array}{ll}8 . & \text { Subsystem } \\
& \text { requirements } \\
& (3.2-1.5)\end{array}$ & $\begin{array}{l}\text { HANDI } 2000 \\
\text { Subsystem requirements data } \\
\text { may be defined on the Project } \\
\text { Information under Note or as a } \\
\text { scparate document listed on the } \\
\text { Justification panel. }\end{array}$ & $\begin{array}{l}\text { HANDI } 2000 \\
\text { OLE link to a } \\
\text { Microsoft }{ }^{\mathrm{TM}} \text { Word } \\
\text { document or Microsoft }{ }^{\mathrm{rM}} \\
\text { Excel spreadsheet. }\end{array}$ & $\begin{array}{l}\text { HANDi2000 } \\
\text { - Ability to OLE link to a } \\
\text { document. } \\
\text { - Project Management/Work } \\
\text { Management allows } \\
\text { management of OLE- } \\
\text { linked document. } \\
\text { - Document is visible to } \\
\text { appropriate parties. }\end{array}$ & $\begin{array}{l}\text { - RPP system requirements } \\
\text { are currently stored in the } \\
\text { HSTD. The linkage } \\
\text { between HANDI } 2000 \text { and } \\
\text { the requirements must be } \\
\text { developed. } \\
\text { - HANDI } 2000 \text { does not } \\
\text { provide subsystem } \\
\text { requirements configuration } \\
\text { management, document } \\
\text { release control, } \\
\text { configuration management, } \\
\text { document markup and } \\
\text { annotation, or broad (non- } \\
\text { serial) review and approval } \\
\text { routing. }\end{array}$ & $\begin{array}{l}\text { See Recommendation } 7.2 \text {. } \\
\text { - See Recommendations } 7.4 \text { and } \\
7.5 \text {. }\end{array}$ \\
\hline 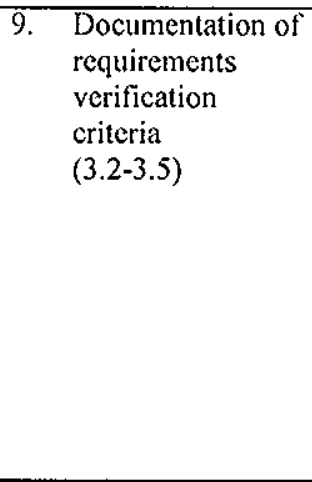 & $\begin{array}{l}\text { IIANDI 2000 } \\
\text { Documentation of requirements } \\
\text { verification criteria data may be } \\
\text { defined on the Project } \\
\text { Information under Notes or as a } \\
\text { separate document listed on the } \\
\text { Justification panel. }\end{array}$ & $\begin{array}{l}\text { HANDI } 2000 \\
\text { OLE link to a } \\
\text { Microsoft } \\
\text { document or Microsoft } \\
\text { Excel spreadsheet. }\end{array}$ & $\begin{array}{l}\text { HANDI 2000 } \\
\text { - Ability to OLE link to a } \\
\text { document. } \\
\text { - Project Management/Work } \\
\text { Management allows } \\
\text { management of OLE- } \\
\text { linked document. } \\
\text { Document is visible to } \\
\text { appropriate parties. }\end{array}$ & $\begin{array}{l}\text { - Requirements verification } \\
\text { criteria are currently stored } \\
\text { in the HSTD. The linkage } \\
\text { between HANDI } 2000 \text { and } \\
\text { the criteria must be } \\
\text { developed. } \\
\text { - HANDI } 2000 \text { does not } \\
\text { provide criteria } \\
\text { configuration management, } \\
\text { document release control, } \\
\text { configuration management, } \\
\text { document markup and } \\
\text { annotation, or broad (non- }\end{array}$ & $\begin{array}{l}\text { - See Recommendation } 7.2 \text {. } \\
\text { - See Recommendations } 7.4 \\
\text { and 7.5. }\end{array}$ \\
\hline
\end{tabular}


Table 5-1. Maturity Assessment//nformation Capability and Functionality Matrix.

\begin{tabular}{|c|c|c|c|c|c|}
\hline (a) & (b) & (c) & (d) & (e) & $(\mathrm{f})$ \\
\hline $\begin{array}{l}\text { Information Need/ } \\
\text { Question Number }\end{array}$ & $\begin{array}{l}\text { General Description of System } \\
\text { Provisions }\end{array}$ & $\begin{array}{l}\text { PHMC HANDI. } 2000 \text { System } \\
\text { Information } \\
\text { Capability }\end{array}$ & $\begin{array}{l}\text { PHMC HANDI } 2000 \text { System } \\
\text { Function } \\
\text {. Capability }\end{array}$ & $\begin{array}{c}\text { User Comment on PHMC } \\
\text { HANDI } 2000 \text { Capability } \\
\left({ }^{*}\right)=\text { intend to resolve with } \\
\text { Interim Stabilization Pilot } \\
\text { Project }\end{array}$ & $\begin{array}{l}\text { SE\&I Response } \\
\text { to } \\
\text { User Comment }\end{array}$ \\
\hline & & & & $\begin{array}{l}\text { serial) review and approval } \\
\text { routing. }\end{array}$ & \\
\hline $\begin{array}{l}\text { 10. Documentation of } \\
\text { verification results } \\
(3.6-2.6)\end{array}$ & $\begin{array}{l}\text { HANDI } 2000 \\
\text { Documentation of verification } \\
\text { results may be entered in the } \\
\text { Project Information, on an } \\
\text { action tracking assignment, or } \\
\text { in the closeout of a work order } \\
\text { task. }\end{array}$ & $\begin{array}{l}\text { HANDI 2000 } \\
\text { - OLE link to a } \\
\text { Microsoft }{ }^{\mathrm{MM}} \text { Word } \\
\text { document or Microsoft } \\
\text { Excel spreadsheet. }\end{array}$ & 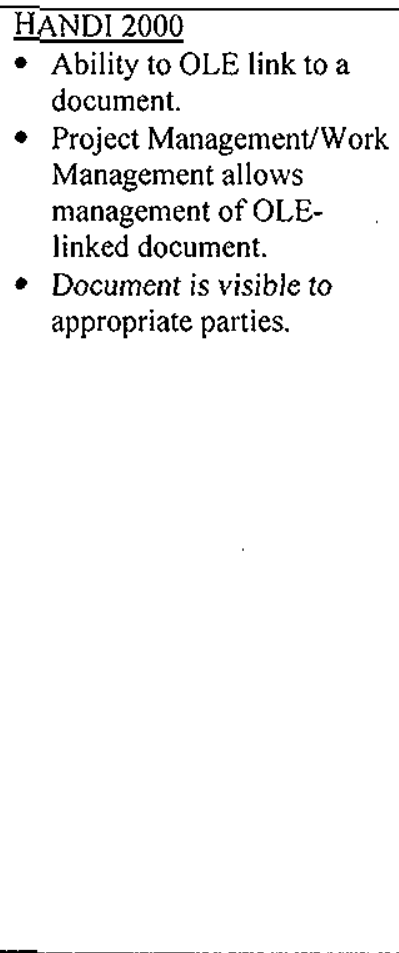 & $\begin{array}{l}\text { Completion of task (Project } \\
\text { Information, action } \\
\text { tracking assignment, or } \\
\text { work order) is recorded, but } \\
\text { output information required } \\
\text { for verification to DOE } \\
\text { may or may not be } \\
\text { available. Standards would } \\
\text { need to be developed that } \\
\text { are acceptable to the } \\
\text { customer. } \\
\text { - Requirements verification } \\
\text { results are currently stored } \\
\text { in the HSTD. The linkage } \\
\text { between HANDI } 2000 \text { and } \\
\text { the criteria must be } \\
\text { developed. } \\
\text { - HANDI } 2000 \text { does not } \\
\text { provide results } \\
\text { configuration management, } \\
\text { document release control, } \\
\text { configuration management, } \\
\text { document markup and } \\
\text { annotation, or broad (non- } \\
\text { serial) review and approval } \\
\text { routing. }\end{array}$ & $\begin{array}{l}\text { - See Recommendation } 7.2 \text {. } \\
\text { - See Recommendations } 7.4 \\
\text { and } 7.5 \text {. }\end{array}$ \\
\hline $\begin{array}{l}\text { 11. Requircments } \\
\text { relationships } \\
(3.2-2.8)\end{array}$ & $\begin{array}{l}\text { HANDI } 2000 \\
\text { The HANDI } 2000 \text { system does } \\
\text { not provide this functionality. }\end{array}$ & $\begin{array}{l}\text { HANDI } 2000 \\
\text { The HANDI } 2000 \text { system } \\
\text { does not provide this } \\
\text { functionality. }\end{array}$ & $\begin{array}{l}\text { HANDI } 2000 \\
\text { The HANDI } 2000 \text { does not } \\
\text { provide this functionality. }\end{array}$ & $\begin{array}{l}\text { - Requirements relationships } \\
\text { are currently stored in the } \\
\text { HSTD. The linkage } \\
\text { between HANDI } 2000 \text { and } \\
\text { the criteria must be } \\
\text { developed. }\end{array}$ & - See Recommendations 7.2 . \\
\hline $\begin{array}{l}\text { 12. Management of } \\
\text { changes to } \\
\text { requirements } \\
(3.2-2.4)\end{array}$ & $\begin{array}{l}\text { HANDI } 2000 \\
\text { The HANDI } 2000 \text { system does } \\
\text { not provide this functionality. }\end{array}$ & $\begin{array}{l}\text { HANDI } 2000 \\
\text { The HANDI } 2000 \text { system } \\
\text { does not provide this } \\
\text { functionality. }\end{array}$ & $\begin{array}{l}\text { HANDI } 2000 \\
\text { The HANDI } 2000 \text { system } \\
\text { does not provide this } \\
\text { functionality. }\end{array}$ & $\begin{array}{l}\text { Poor configuration } \\
\text { management of } \\
\text { requirements (anyone can } \\
\text { seem to write a } \\
\text { requirement). } \\
\text { - Change control of }\end{array}$ & $\begin{array}{l}\text { - See item } 11 . \\
\text { - Technical and safety }\end{array}$ \\
\hline
\end{tabular}


Table 5-1. Maturity Assessment/Information Capability and Functionality Matrix.

\begin{tabular}{|c|c|c|c|c|c|}
\hline (a) & (b) & (c) & (d) & (e) & (f) \\
\hline $\begin{array}{l}\text { Information Need/ } \\
\text { Question Number }\end{array}$ & $\begin{array}{l}\text { General Description of System } \\
\text { Provisions }\end{array}$ & $\begin{array}{l}\text { PHMC HANDI } 2000 \text { System } \\
\text { Information } \\
\text { Capability }\end{array}$ & $\begin{array}{l}\text { PHMC HANDI } 2000 \text { System } \\
\text { Function } \\
\text { Capability }\end{array}$ & $\begin{array}{c}\text { User Comment on PHMC } \\
\text { HANDI } 2000 \text { Capability } \\
\left(^{*}\right)=\text { intend to resolve with } \\
\text { Interim Stabilization Pilot } \\
\text { Project }\end{array}$ & $\begin{array}{l}\text { SE\&I Response } \\
\text { to } \\
\text { User Comment }\end{array}$ \\
\hline & & & & $\begin{array}{l}\text { requirements in the system } \\
\text { is in effect. Implementation } \\
\text { of the ECC and Documents } \\
\text { modules would give the } \\
\text { means for interfacing } \\
\text { control of requirements. }\end{array}$ & $\begin{array}{l}\text { requirements will be initiated } \\
\text { through the HANDI } 2000 \\
\text { ECC module. However, the } \\
\text { RPP plan is to control changes } \\
\text { through the HSTD } \\
\text { requirements configuration } \\
\text { management functions. See } \\
\text { Recommendation } 7.2 \text {. } \\
\text { Document control will be } \\
\text { managed through the } \\
\text { document configuration } \\
\text { management system. See } \\
\text { Recommendations } 7.4 \text { and } 7.5 \text {. }\end{array}$ \\
\hline $\begin{array}{l}\text { 13. Generic issue in } \\
\text { design: Design } \\
\text { review criteria } \\
\text { should be } \\
\text { available to all } \\
\text { involved } \\
\text { (All of } \\
\text { Scction } 3.3 \text { ) }\end{array}$ & $\frac{\text { HANDI } 2000}{\text { See item 35. }}$ & $\frac{\text { HANDI } 2000}{\text { See item } 35 .}$ & $\frac{\text { HANDI } 2000}{\text { See item } 35 .}$ & $\begin{array}{l}\text { Reviewers' comments } \\
\text { should be visible to all } \\
\text { other reviewers in "real- } \\
\text { time" fashion rather than } \\
\text { continuous recirculation of } \\
\text { adjustments as done today. } \\
\text { Other than emergency } \\
\text { changes, reviews of designs } \\
\text { and procedures currently } \\
\text { require } 3 \text { to } 5 \text { weeks for } \\
\text { review and comment. }\end{array}$ & $\begin{array}{l}\text { - See Recommendations } 7.3 \text { and } \\
7.5 \text {. }\end{array}$ \\
\hline
\end{tabular}


Table 5-1. Maturity Assessment/Information Capability and Functionality Matrix.

\begin{tabular}{|c|c|c|c|c|c|}
\hline (a) & (b) & (c) & (d) & (e) & (f) \\
\hline $\begin{array}{l}\text { Information Need/ } \\
\text { Question Number }\end{array}$ & $\begin{array}{l}\text { General Description of System } \\
\text { Provisions }\end{array}$ & $\begin{array}{c}\text { PHMC HANDI } 2000 \text { System } \\
\text { Information } \\
\text { Capability }\end{array}$ & $\begin{array}{l}\text { PHMC HANDI } 2000 \text { System } \\
\text { Function } \\
\text { Capability }\end{array}$ & $\begin{array}{l}\text { User Comment on PHMC } \\
\text { HANDI } 2000 \text { Capability } \\
\left({ }^{*}\right)=\text { intend to resolve with } \\
\text { Interim Stabilization Pilot } \\
\text { Project }\end{array}$ & $\begin{array}{l}\text { SE\&I Response } \\
\text { to } \\
\text { User Comment }\end{array}$ \\
\hline $\begin{array}{l}\text { 14. Configuration } \\
\text { items are } \\
\text { identified } \\
(1.5-2.3)\end{array}$ & $\begin{array}{l}\text { HANDI } 2000 \\
\text { There is not a specific place to } \\
\text { identify whether a HANDI } \\
2000 \text { object is a "configuration } \\
\text { item," however, all work } \\
\text { products placed in HANDI } \\
2000 \text { are managed to ensure } \\
\text { configuration of the data. The } \\
\text { process rules used by Hanford } \\
\text { to use the tool will determine } \\
\text { the rigor of control required. It } \\
\text { is not such a finitc question. } \\
\text { To ask if configuration is- } \\
\text { controlled YES or NO--is not } \\
\text { easily answered. HANDI } 2000 \\
\text { allows the rigor of control to be } \\
\text { determined by Hanford for } \\
\text { each object managed in } \\
\text { HANDI 2000. Levels of } \\
\text { approval, routing for review, } \\
\text { and access to perform functions } \\
\text { are granted individually to the } \\
\text { individuals required. } \\
\text { Hanford work products } \\
\text { managed in HANDI } 2000 \text { at } \\
\text { the present time include } \\
\text { materials (Inventory } \\
\text { Management) material } \\
\text { requests, contracts, purchase } \\
\text { requests, and purchase orders. } \\
\text { This functionality is provided } \\
\text { by the Inventory, Contracts, } \\
\text { and Purchasing modules. } \\
\text { Adding the Project } \\
\text { Management modute will place } \\
\text { Projects (TBRs) under } \\
\text { configuration management. } \\
\text { The Project Information (risks, } \\
\text { metrics, scope, schedule }\end{array}$ & $\begin{array}{l}\text { HANDI } 2000 \\
\text { - Equipment location data } \\
\text { in the Work Management } \\
\text { module of HANDI } 2000 \text {. } \\
\text { - Manufacturer/model/bill } \\
\text { of materials linking the } \\
\text { inventory catalog to } \\
\text { equipment locations. } \\
\text { - Document Control and } \\
\text { Records Management } \\
\text { modules of HANDI } 2000 . \\
\text { - ECC module of } \\
\text { HANDI } 2000 \text {. } \\
\text { - Action tracking requests } \\
\text { and assignments. } \\
\text { - Project Management data, } \\
\text { cost plans, and schedule } \\
\text { plans. } \\
\text { - Work request and work } \\
\text { order (task) packages } \\
\text { managed by the Work } \\
\text { Management module of } \\
\text { HANDI 2000. }\end{array}$ & $\begin{array}{l}\text { HANDI 2000 } \\
\text { - Ability to manage the } \\
\text { changes to equipment } \\
\text { locations, bill of materials, } \\
\text { drawings, controlled } \\
\text { documents, work } \\
\text { packages, repetitive tasks, } \\
\text { preventative maintenance } \\
\text { tasks, Project Information } \\
\text { (including budgets and } \\
\text { schedule), action } \\
\text { assignments, engineering } \\
\text { changes, and other items } \\
\text { placed under configuration } \\
\text { management. } \\
\text { Ability to drill down } \\
\text { between HANDI } 2000 \\
\text { objects that are configured } \\
\text { and maintained in } \\
\text { HANDI } 2000 \text {. For } \\
\text { instance, an action request } \\
\text { to investigate a generic } \\
\text { equipment problem may } \\
\text { result in actions that } \\
\text { launch investigative work } \\
\text { requests that may result in } \\
\text { a project. The project may } \\
\text { include an engineering } \\
\text { change to install new } \\
\text { equipment with work } \\
\text { order task packages. } \\
\text { material requests are } \\
\text { created that turn into } \\
\text { purchase requests that } \\
\text { result in purchase orders or } \\
\text { contracts. All of these } \\
\text { items are automatically } \\
\text { linked, which enables drill } \\
\text { down. This is the } \\
\text { capability that enables } \\
\text { configuration } \\
\end{array}$ & $\begin{array}{l}\text { Configuration management } \\
\text { will be more disciplined } \\
\text { with the system. But, we } \\
\text { will need to change the } \\
\text { philosophy of users through } \\
\text { stakeholders in the use of } \\
\text { disciplined systems relating } \\
\text { to configuration } \\
\text { management to take } \\
\text { advantage of system } \\
\text { capabilities. } \\
\text { - Implementation of Work } \\
\text { control and ECC modules } \\
\text { will provide the basic tools } \\
\text { for configuration } \\
\text { management. Control of } \\
\text { data within the system is } \\
\text { implemented by security of } \\
\text { data entry/revision abilities } \\
\text { and recording of who made } \\
\text { the changes. } \\
\\
\text { Change in philosophy of } \\
\text { users will require } \\
\text { development of explicit } \\
\text { training module on the use } \\
\text { of the system capabilities } \\
\text { for configuration } \\
\text { management. }\end{array}$ & $\begin{array}{l}\text { - User philosophy will be } \\
\text { changed through training, } \\
\text { procedures, management } \\
\text { support, and discipline. } \\
\\
\text { - Contiguration items are } \\
\text { identified by way of the } \\
\text { configuration management } \\
\text { process. Maintenance of the } \\
\text { detail item list will be done } \\
\text { using the HSTD configuration } \\
\text { management functionality. } \\
\text { Document release and } \\
\text { configuration is controlled } \\
\text { through the configuration } \\
\text { management system. Sec } \\
\text { Recommendations } 7.2,7.4, \\
\text { and } 7.5 \text {. } \\
\text { As stated above, user } \\
\text { philosophy will be changed } \\
\text { through training, procedures, } \\
\text { management support, and } \\
\text { discipline. }\end{array}$ \\
\hline
\end{tabular}


Table 5-1. Maturity Assessment/Information Capability and Functionality Matrix.

\begin{tabular}{|c|c|c|c|c|c|}
\hline (a) & (b) & (c) & (d) & (e) & (f) \\
\hline $\begin{array}{l}\text { Information Need/ } \\
\text { Question Number }\end{array}$ & $\begin{array}{c}\text { General Description of System } \\
\text { Provisions }\end{array}$ & $\begin{array}{l}\text { PHMC HANDI } 2000 \text { System } \\
\text { Information } \\
\text { Capability }\end{array}$ & $\begin{array}{l}\text { PHMC HANDI } 2000 \text { System } \\
\text { Function } \\
\text { Capability }\end{array}$ & $\begin{array}{c}\text { User Comment on PHMC } \\
\text { HANDI } 2000 \text { Capability } \\
\left({ }^{*}\right)=\text { intend to resolve with } \\
\text { Interim Stabilization Pilot } \\
\text { Project }\end{array}$ & $\begin{array}{l}\text { SE\&I Response } \\
\text { to } \\
\text { User Comment }\end{array}$ \\
\hline & $\begin{array}{l}\text { versions, cost plan versions) } \\
\text { will be controlled by the } \\
\text { designated project manager and } \\
\text { delegates defined in the project. } \\
\text { Project Information approval is } \\
\text { separate from budget/schedule } \\
\text { approval. } \\
\text { The equipment location data } \\
\text { are provided to manage the } \\
\text { information pertinent to each } \\
\text { equipment location. Bill of } \\
\text { material information, location } \\
\text { data, document references, } \\
\text { parameters, installation history, } \\
\text { and other information about the } \\
\text { equipment is closely controlled } \\
\text { in HANDI 2000. The ECC } \\
\text { module will provide control of } \\
\text { design change documentation } \\
\text { and provide a link between the } \\
\text { change and the Documents and } \\
\text { Records Control module } \\
\text { functions. Implementation of } \\
\text { the engineering change is } \\
\text { provided by the Work } \\
\text { Management module that } \\
\text { provides the tools to perform } \\
\text { and document the fieldwork } \\
\text { pcrformed. Work Management } \\
\text { also provides a framework for } \\
\text { scheduling the work in the } \\
\text { context of all of the other } \\
\text { scheduled work such as } \\
\text { corrective maintenance and } \\
\text { preventative maintenance. } \\
\text { Work Management also } \\
\text { provides the link to the material } \\
\text { request, contracts, and } \\
\text { purchasing functionality }\end{array}$ & $\cdot$ & $\begin{array}{l}\text { management. } \\
\text { Integration of the } \\
\text { Engineering Change } \\
\text { functionality with } \\
\text { Document Control and } \\
\text { Work Management. This } \\
\text { provides a link between } \\
\text { the design change and the } \\
\text { resulting changes to } \\
\text { documents and to the } \\
\text { actual work performed to } \\
\text { implement the change. } \\
\text { - Integration of Work } \\
\text { Management with } \\
\text { Contracts, Materials, and } \\
\text { Purchasing. This } \\
\text { functionality provides the } \\
\text { pedigree of purchased } \\
\text { equipment from receipt } \\
\text { through installation and } \\
\text { maintenance/testing. }\end{array}$ & & - \\
\hline
\end{tabular}


Table 5-1. Maturity Assessment/Information Capability and Functionality Matrix.

\begin{tabular}{|c|c|c|c|c|c|}
\hline (a) & (b) & (c) & (d) & (e) & (f) \\
\hline $\begin{array}{l}\text { Information Need / } \\
\text { Question Number }\end{array}$ & $\begin{array}{l}\text { General Description of System } \\
\text { Provisions }\end{array}$ & $\begin{array}{l}\text { PHMC HANDI } 2000 \text { System } \\
\text { Information } \\
\text { Capability }\end{array}$ & $\begin{array}{l}\text { PHMC HANDI } 2000 \text { System } \\
\text { Function } \\
\text { Capability }\end{array}$ & $\begin{array}{c}\text { User Comment on PHMC } \\
\text { HANDI } 2000 \text { Capability } \\
\left({ }^{*}\right)=\text { intend to resolve with } \\
\text { Interim Stabilization Pilot } \\
\text { Project }\end{array}$ & $\begin{array}{c}\text { SE\&I Response } \\
\text { to } \\
\text { User Comment }\end{array}$ \\
\hline & $\begin{array}{l}\text { already implemented at } \\
\text {.Hanford that completes the } \\
\text { work process circle. The } \\
\text { PassPort/PcopleSof } \\
\text { functionality presently in use is } \\
\text { not linked to the fieldwork } \\
\text { except through manual update } \\
\text { of P3 schedules and high-level } \\
\text { rollup of costs by FDH. } \\
\text { Project level rollup of cost and } \\
\text { schedule information is a } \\
\text { byproduct of (or maybe the } \\
\text { result of the functionality used } \\
\text { to manage configuration. }\end{array}$ & & & & \\
\hline $\begin{array}{l}\text { 15. Configuration } \\
\text { items are statused } \\
(1.5-3.2)\end{array}$ & $\begin{array}{l}\text { HANDI } 2000 \\
\text { HANDI } 2000 \text { objects (e.g., an } \\
\text { equipment location, } \\
\text { engineering change, work } \\
\text { request, work order task, action } \\
\text { rqquest) are managed through a } \\
\text { life cycle by controlling a } \\
\text { series of changes in status. For } \\
\text { instance, an equipment location } \\
\text { may have a status of DESIGN, } \\
\text { ACTIVE, INACTIVE, } \\
\text { REMOVED, RETIRED, or } \\
\text { DELETED. } \\
\text { Work order task status } \\
\text { progresses through PLAN, } \\
\text { HOLD/APPROVAL, } \\
\text { APPROVED, READY TO } \\
\text { WORK, WORKING, } \\
\text { FINISHED, OPS REVIEW, } \\
\text { COMPLETE, and CLOSED. } \\
\text { Action requests are managed } \\
\text { with the following Status: } \\
\text { HOLD/APPROVAL, PRE- } \\
\text { APPROVED, APPROVED, IN } \\
\text { PROGRESS, CANCELLED, }\end{array}$ & $\begin{array}{l}\text { HANDI } 2000 \\
\text { - HANDI } 2000 \text { security } \\
\text { that controls the ability to } \\
\text { change object status. } \\
\text { - HANDI } 2000 \text { drill-down } \\
\text { capability between related } \\
\text { objects. } \\
\text { - HANDI } 2000 \text { AAA } \\
\text { routing functionality. }\end{array}$ & $\begin{array}{l}\text { HANDI } 2000 \\
\text { Integration of the ECC } \\
\text { functionality with } \\
\text { Document Control and } \\
\text { Work Management. This } \\
\text { provides a link between } \\
\text { the design change and the } \\
\text { resulting changes to } \\
\text { documents and to the } \\
\text { actual work performed to } \\
\text { implement the change. } \\
\text { Engineering changes may } \\
\text { not be closed out with } \\
\text { outstanding work packages } \\
\text { that are not "Complete." } \\
\text { Integration of Work } \\
\text { Management with } \\
\text { Contracts, Materials, and } \\
\text { Purchasing. This } \\
\text { functionality provides the } \\
\text { pedigree of purchased } \\
\text { equipment from receipt } \\
\text { through installation and } \\
\text { maintenance/testing. } \\
\text { Purchasing of a catalog is } \\
\text { not allowed until the } \\
\text { catalog item is in }\end{array}$ & $\begin{array}{l}\text { There are three products } \\
\text { required to enable an } \\
\text { effective change in our } \\
\text { configuration management } \\
\text { discipline: (1) ECC, } \\
\text { (2) Document } \\
\text { Management, and } \\
\text { (3) Curator. Without these } \\
\text { products, the rest of the } \\
\text { HANDI 2000 modules } \\
\text { currently installed and } \\
\text { proposed to be installed are } \\
\text { significantly reduced in } \\
\text { effectiveness. } \\
\\
\\
\text { Change in philosophy of } \\
\text { users will require } \\
\text { development of explicit } \\
\text { training module on the use } \\
\text { of the system capabilities } \\
\text { for configuration } \\
\text { management. }\end{array}$ & $\begin{array}{l}\text { - DOE owns the Document } \\
\text { Management module and } \\
\text { LMHC Systems Engineering } \\
\text { will submit an FY } 2000 \\
\text { budget request to procure ECC } \\
\text { module and Curator, a } \\
\text { document and drawing } \\
\text { configuration management } \\
\text { system. Requirements } \\
\text { configuration items will be } \\
\text { statused through the HSTD } \\
\text { configuration management } \\
\text { functionality. Document and } \\
\text { drawing contiguration items } \\
\text { will be statused using the } \\
\text { configuration management } \\
\text { system. See } \\
\text { Recommendations } 7.2,7.4 . \\
\text { and } 7.5 \text {. } \\
\text { - User philosophy will be } \\
\text { changed through training, } \\
\text { procedures, managcment } \\
\text { support, and discipline. }\end{array}$ \\
\hline
\end{tabular}


Table 5-1. Maturity Assessment//nformation Capability and Functionality Matrix.

\begin{tabular}{|c|c|c|c|c|c|}
\hline (a) & (b) & (c) & (d) & (e) & (f) \\
\hline \multirow[t]{2}{*}{$\begin{array}{l}\text { Information Need/ } \\
\text { Question Number }\end{array}$} & $\begin{array}{l}\text { General Description of System } \\
\cdot \quad \text { Provisions }\end{array}$ & $\begin{array}{l}\text { PHMC HANDI } 2000 \text { System } \\
\text { Information } \\
\text { Capability }\end{array}$ & $\begin{array}{l}\text { PHMC HANDI } 2000 \text { System } \\
\text { Function } \\
\text { Capability }\end{array}$ & $\begin{array}{c}\text { User Comment on PHMC } \\
\text { HANDI } 2000 \text { Capability } \\
\left({ }^{*}\right)=\text { intend to resolve with } \\
\text { Interim Stabilization Pilot } \\
\text { Project }\end{array}$ & $\begin{array}{l}\text { SE\&I Response } \\
\text { to } \\
\text { User Comment }\end{array}$ \\
\hline & $\begin{array}{l}\text { COMPLETE or REJECTED. } \\
\text { Engineering changes are } \\
\text { managed with the following } \\
\text { status: PENDING, ISSUED, } \\
\text { ACTIVE, COMPLETE, } \\
\text { CANCEL, or SUPERSEDE. }\end{array}$ & & $\begin{array}{l}\text { "Approved" status. } \\
\text { Ability to route } \\
\text { engineering changes, } \\
\text { documents, and work } \\
\text { orders to the appropriate } \\
\text { individuals for review and } \\
\text { approval. Status changes } \\
\text { are controlled by the } \\
\text { completion of the routing. }\end{array}$ & & \\
\hline $\begin{array}{l}\text { 16. Configuration } \\
\text { items are } \\
\text { developed from } \\
\text { system } \\
\text { requirements by } \\
\text { appropriate teams } \\
(1.4-3.3)\end{array}$ & $\begin{array}{l}\text { HANDI 2000 } \\
\text { Configuration items are entered } \\
\text { into HANDI } 2000 \text {. Equipment } \\
\text { configuration and document } \\
\text { configuration are both provided } \\
\text { for in HANDI } 2000 \text {. There is } \\
\text { no functionality associated with } \\
\text { picking which items are placed } \\
\text { under configuration control. } \\
\text { ltems selected to be placed } \\
\text { under configuration } \\
\text { management will be entered } \\
\text { into HANDI } 2000 \text { and then } \\
\text { managed using the HANDI } \\
2000 \text { functionality. HANDI } \\
2000 \text { maintains the linkage } \\
\text { between the objects such as } \\
\text { between a design change and } \\
\text { the resulting document } \\
\text { changes. Another example is } \\
\text { betwcen a design change and } \\
\text { the resulting work order task } \\
\text { packages used to install the } \\
\text { new design. }\end{array}$ & $\begin{array}{l}\text { HANDI } 2000 \\
\text { Equipment data in the } \\
\text { Work Management } \\
\text { module of HANDI } 2000 . \\
\text { Document Control and } \\
\text { Records Management } \\
\text { modules of HANDI } 2000 \text {. } \\
\text { - ECC module of HANDI } \\
2000 \text {. } \\
\text { - Action tracking requests } \\
\text { and assignments. } \\
\text { - Project management data } \\
\text { cost plans and schedule } \\
\text { plans. } \\
\text { Work request and work } \\
\text { order (task) packages } \\
\text { managed by the Work } \\
\text { Management module of } \\
\text { HANDl 2000. }\end{array}$ & $\begin{array}{l}\text { HANDI } 2000 \\
\text { Ability to manage the } \\
\text { changes to equipment } \\
\text { locations, bill of materials, } \\
\text { drawings, controlled } \\
\text { documents, work } \\
\text { packages, repetitive tasks, } \\
\text { preventative maintenance } \\
\text { tasks, Project Information } \\
\text { (including budgets and } \\
\text { schedule), action } \\
\text { assignments, engineering } \\
\text { changes, and other items } \\
\text { placed under configuration } \\
\text { management. } \\
\text { - Ability to drill down } \\
\text { between HANDI } 2000 \\
\text { objects that are configured } \\
\text { and maintained in HANDI } \\
\text { 2000. For instance, an } \\
\text { action request to } \\
\text { investigate a generic } \\
\text { equipment problem may } \\
\text { result in actions that } \\
\text { launch investigative work } \\
\text { requests that may result in } \\
\text { a project. } \\
\text { The project may include } \\
\text { an engineering change to } \\
\text { install new equipment with } \\
\text { work order task packages. } \\
\text { Material requests are }\end{array}$ & $\begin{array}{l}\text { Need to evaluate our } \\
\text { requirement set and reduce } \\
\text { them to necessary and } \\
\text { sufficient requirements to } \\
\text { meet laws, regulations, } \\
\text { orders, etc. }\end{array}$ & $\begin{array}{l}\text { - Per the ORP manager, PHMC } \\
\text { has initiated a task to identify } \\
\text { minimum requirements. }\end{array}$ \\
\hline
\end{tabular}


RPP-4773, Rev. 0

\begin{tabular}{|c|c|c|c|c|}
\hline$\Theta$ & 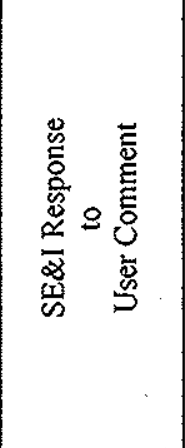 & & 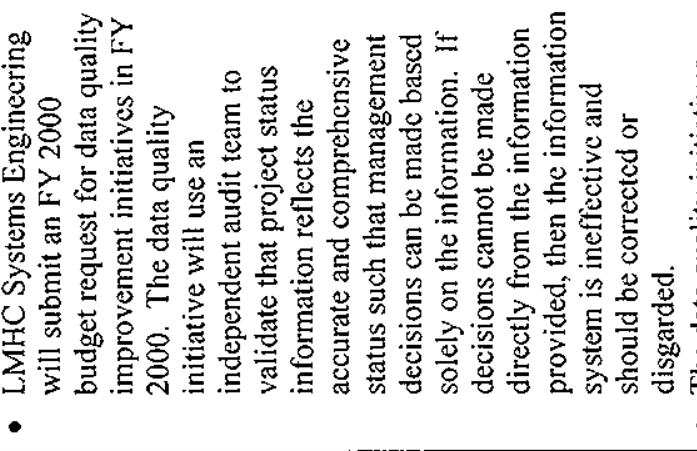 & 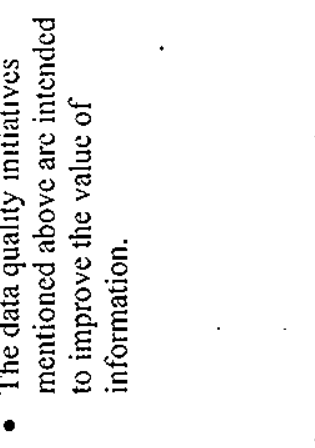 \\
\hline & 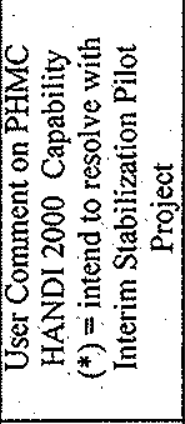 & & 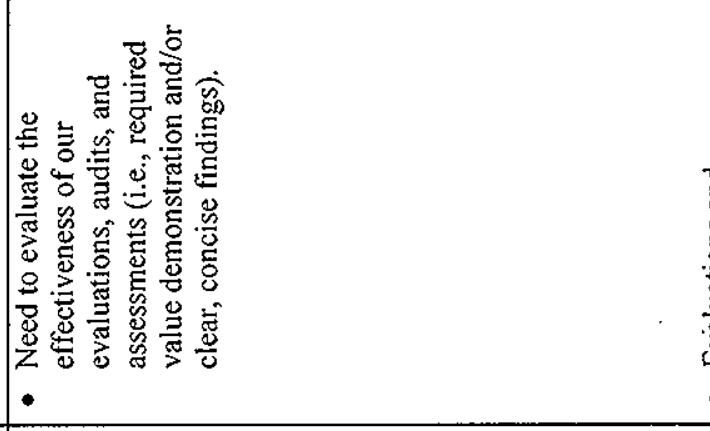 & 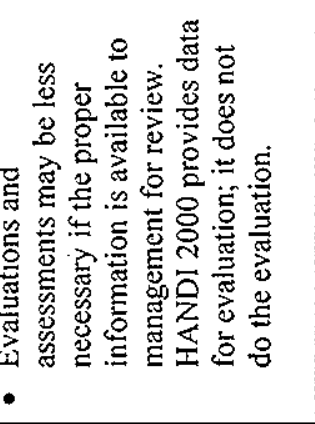 \\
\hline (2) & 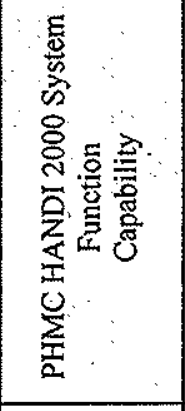 & 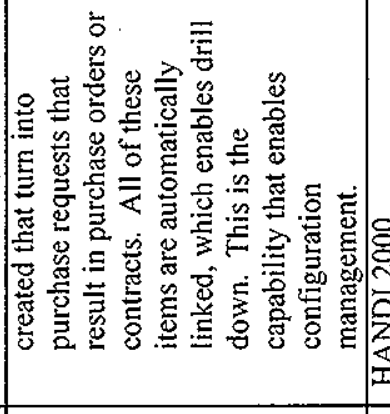 & \multicolumn{2}{|c|}{ 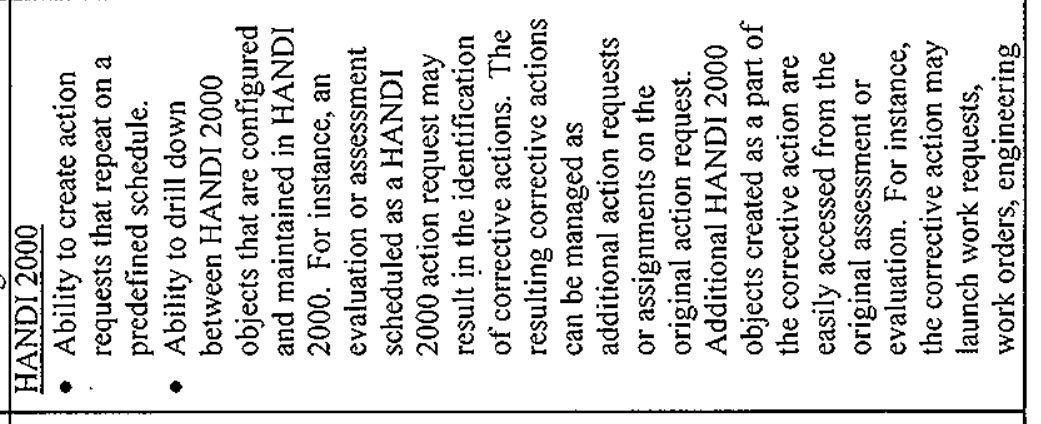 } \\
\hline (3) & 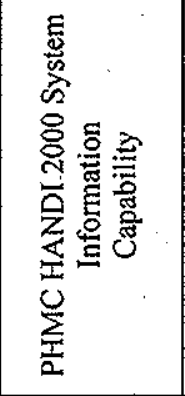 & & 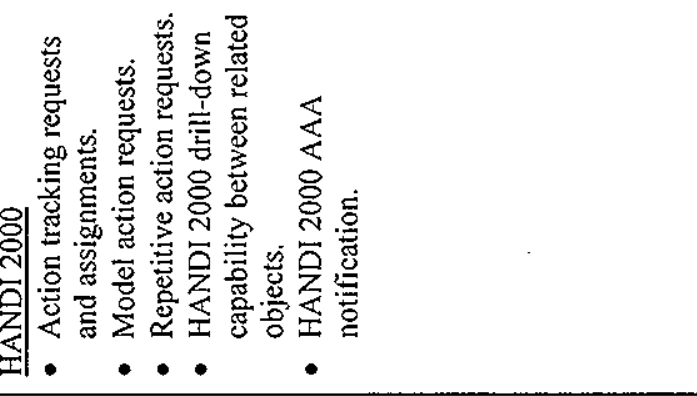 & \\
\hline ق & 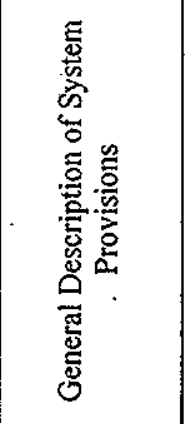 & & 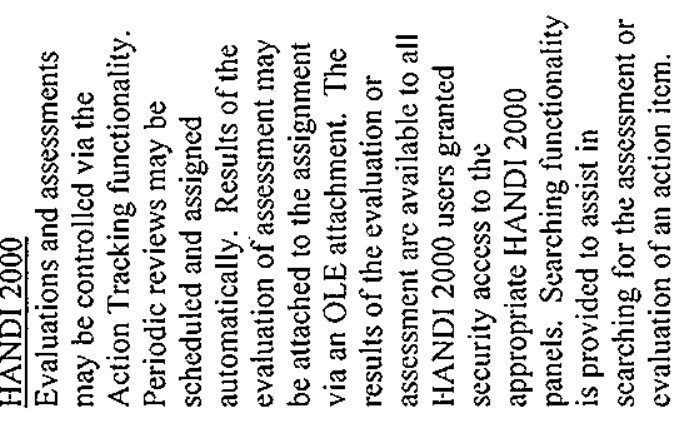 & 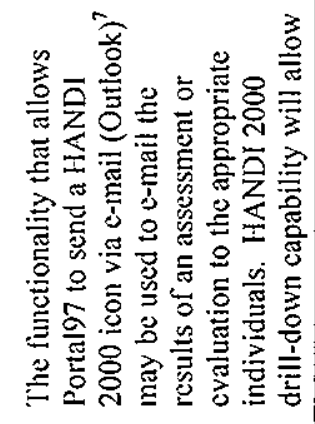 \\
\hline$\Xi$ & 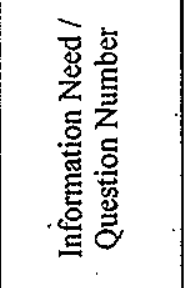 & & 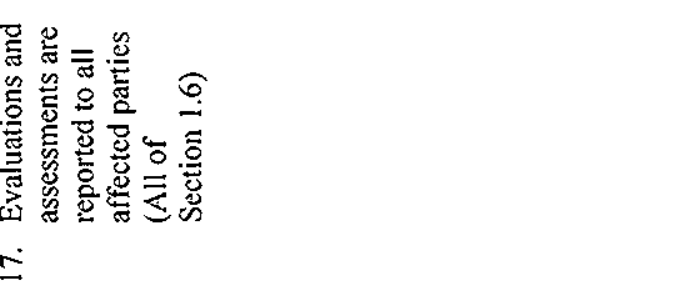 & \\
\hline
\end{tabular}


Table 5-1. Maturity Assessment/Information Capability and Functionality Matrix.

\begin{tabular}{|c|c|c|c|c|c|}
\hline (a) & (b) & (c) & (d) & (e) & (f) \\
\hline $\begin{array}{l}\text { Information Need / } \\
\text { Question Number }\end{array}$ & $\begin{array}{c}\text { General Description of System } \\
\text { Provisions }\end{array}$ & $\begin{array}{l}\text { PHMC HANDI } 2000 \text { System } \\
\text { Information } \\
\text { Capability }\end{array}$ & $\begin{array}{l}\text { PHMC HANDI } 2000 \text { System } \\
\text { Function } \\
\text { Capability }\end{array}$ & $\begin{array}{c}\text { User Comment on PHMC } \\
\text { HANDI } 2000 \text { Capability } \\
\left({ }^{*}\right)=\text { intend to resolve with } \\
\text { Interim Stabilization Pilot } \\
\text { Project }\end{array}$ & $\begin{array}{c}\text { SE\&I Response } \\
\text { to } \\
\text { User Comment }\end{array}$ \\
\hline & $\begin{array}{l}\text { those reviewers to casily access } \\
\text { any engineering changes, work } \\
\text { orders, action requests, } \\
\text { contracts, purchase orders, or } \\
\text { other HANDI } 2000 \text { objects } \\
\text { crcated as a result of the } \\
\text { assessment or evaluation. }\end{array}$ & . & $\begin{array}{l}\text { changes, contracts, } \\
\text { material requests, etc. All } \\
\text { of these items exist in } \\
\text { HANDI } 2000 \text { and will be } \\
\text { linked to the original } \\
\text { action request and to each } \\
\text { other as appropriate. } \\
\text { - Ability to send a HANDI } \\
2000 \text { icon to appropriate } \\
\text { individuals. This allows } \\
\text { an action item to be sent } \\
\text { for an evaluation to } \\
\text { affected individuals. } \\
\text { Persons receiving the } \\
\text { e-mail with the HANDI } \\
\text { 2000 icon need only } \\
\text { double-click on the icon } \\
\text { and HANDI } 2000 \text { will } \\
\text { start. After entering the } \\
\text { login ID and password, the } \\
\text { user will be taken directly } \\
\text { to the action request that } \\
\text { initiated the evaluation or } \\
\text { assessment. } \\
\text { - HANDI } 2000 \text { will send a } \\
\text { AAA notification to the } \\
\text { assignee of a repetitive } \\
\text { assessment or evaluation } \\
\text { set up in HANDI } 2000 \\
\text { using repetitive action } \\
\text { requests. }\end{array}$ & $\begin{array}{l}\text { To be effective, evaluation } \\
\text { and assessment reviews and } \\
\text { results must become } \\
\text { timely actions. Other than } \\
\text { emergency situations, } \\
\text { reviews of evaluations and } \\
\text { assessments currently } \\
\text { require } 3 \text { to } 5 \text { weeks for } \\
\text { review and comment } \\
\text { information. }\end{array}$ & $\begin{array}{l}\text { See Recommendation } 7.5 \text {. } \\
\text { Under the configuration } \\
\text { management system, routings } \\
\text { generate actions to a } \\
\text { predefined list of reviewers } \\
\text { that can be modified "on the } \\
\text { fly" as reviewers deem } \\
\text { necessary. Reviewers' } \\
\text { comments are visiblc to all } \\
\text { other reviewers in "real-time" } \\
\text { fashion rather than continuous } \\
\text { recirculation of adjustments as } \\
\text { done today. }\end{array}$ \\
\hline $\begin{array}{l}\text { 18. Evaluations and } \\
\text { assessments are } \\
\text { available } \\
\text { (All of } \\
\text { Section 1.6) }\end{array}$ & $\frac{\text { HANDI } 2000}{\text { Sce item } 17 .}$ & $\frac{\text { HANDI } 2000}{\text { See item } 17 .}$ & $\frac{\text { HANDI } 2000}{\text { See item } 17 .}$ & $\begin{array}{l}\text { To ensure general user } \\
\text { access, neither training nor } \\
\text { specialized services should } \\
\text { be required to access the } \\
\text { information. }\end{array}$ & $\begin{array}{l}\text { - See Recommendation } 7.3 \text { on } \\
\text { the Executive Information } \\
\text { System. }\end{array}$ \\
\hline $\begin{array}{l}\text { 19. Quality } \\
\text { Management } \\
\text { activities are } \\
\text { statused for } \\
\text { conformance to }\end{array}$ & $\begin{array}{l}\text { HANDI } 2000 \\
\text { Quality Management activities } \\
\text { may be managed totally in } \\
\text { HANDI } 2000 \text {. The } \\
\text { evaluations, assessments, and }\end{array}$ & $\begin{array}{l}\text { HANDI } 2000 \\
\text { - HANDI } 2000 \text { security } \\
\text { that controls the ability to } \\
\text { change object status. } \\
\text { - HANDI } 2000 \text { drill-down }\end{array}$ & $\begin{array}{l}\text { HANDI } 2000 \\
\text { - HANDI } 2000 \text { action } \\
\text { tracking only allows the } \\
\text { modification or } \\
\text { completion of an }\end{array}$ & $\begin{array}{l}\text { Status information requires } \\
\text { input of data to the system. } \\
\text { Actions and other steps can } \\
\text { be taken, but this is the } \\
\text { function of operating }\end{array}$ & $\begin{array}{l}\text { The concerns expressed by } \\
\text { RPP individuals about } \\
\text { increased input requirements } \\
\text { and time-consuming data }\end{array}$ \\
\hline
\end{tabular}


Table 5-1. Maturity Assessment/Information Capability and Functionality Matrix.

\begin{tabular}{|c|c|c|c|c|c|}
\hline (a) & (b) & (c) & (d) & (e) & (f) \\
\hline $\begin{array}{l}\text { Information Need/ } \\
\text { Question Number }\end{array}$ & $\begin{array}{c}\text { General Description of System } \\
\text { Provisions }\end{array}$ & $\begin{array}{l}\text { PHMC HANDI } 2000 \text { System } \\
\text { Information } \\
\text { Capability }\end{array}$ & $\begin{array}{l}\text { PHMC HANDI } 2000 \text { System } \\
\text { Function } \\
\text { Capability }\end{array}$ & $\begin{array}{l}\text { User Comment on PHMC } \\
\text { HANDI } 2000 \text { Capability } \\
\left({ }^{*}\right)=\text { intend to resolve with } \\
\text { Interim Stabilization Pilot } \\
\text { Project }\end{array}$ & $\begin{array}{c}\text { SE\&I Response } \\
\text { to } \\
\text { User Comment }\end{array}$ \\
\hline $\begin{array}{l}\text { plans } \\
(1.6-2.7)\end{array}$ & $\begin{array}{l}\text { audits may be scheduled and/or } \\
\text { assigned via a HANDI } 2000 \\
\text { action request. Resulting } \\
\text { actions or corrective measures } \\
\text { may also be managed via } \\
\text { HANDI } 2000 \text { action requests } \\
\text { for the individual assignments. } \\
\text { Other HANDI } 2000 \text { items that } \\
\text { may be created as a result of } \\
\text { the original audit, assessment, } \\
\text { or evaluation are linked to the } \\
\text { original action request. } \\
\text { All HANDI } 2000 \text { objects } \\
\text { including action requests are } \\
\text { managed via a series of status } \\
\text { changes. HANDI } 2000 \text { action } \\
\text { request statuses include: } \\
\text { INPROG, PRE-APPROVED, } \\
\text { APPROVED, CANCELLED, } \\
\text { REJECTED and COMPLETE. } \\
\text { All of the other resulting } \\
\text { HANDI } 2000 \text { objects (e.g., } \\
\text { work orders, engineering } \\
\text { changes, projects, contracts, } \\
\text { material requests) also are } \\
\text { managed with status changes. } \\
\text { Sec item } 15 \text {. }\end{array}$ & $\begin{array}{l}\text { capability between related } \\
\text { objects. }\end{array}$ & $\begin{array}{l}\text { assignment by the "Owed } \\
\text { To" individual or group. } \\
\text { - Ability to drill down } \\
\text { between HANDI } 2000 \\
\text { objects that are configured } \\
\text { and maintained in HANDI } \\
\text { 2000. For instance, an } \\
\text { evaluation or assessment } \\
\text { scheduled as a HANDI } \\
\text { 2000 action request may } \\
\text { result in the identification } \\
\text { of corrective actions. The } \\
\text { resulting corrective actions } \\
\text { can be managed as } \\
\text { additional action requests } \\
\text { or assignments on the } \\
\text { original action request. } \\
\text { Additional HANDI } 2000 \\
\text { objects created as a part of } \\
\text { the corrective action are } \\
\text { easily accessed from the } \\
\text { original assessment or } \\
\text { evaluation. For instance, } \\
\text { the corrective action may } \\
\text { launch work requests, } \\
\text { work orders, engineering } \\
\text { changes, contracts, } \\
\text { material requests, etc. All } \\
\text { of these items exist in } \\
\text { HANDI } 2000 \text { and will be } \\
\text { linked to the original } \\
\text { action request and to each } \\
\text { other as appropriate. }\end{array}$ & $\begin{array}{l}\text { procedures and practices } \\
\text { using the tools available. } \\
\text {. } \\
\text { Can intermediate status } \\
\text { (i.e., more information on } \\
\text { the INPROG items) be } \\
\text { captured in "notes" entries? }\end{array}$ & $\begin{array}{l}\text { entry must be balance by the } \\
\text { value of information provided } \\
\text { to decision makers. The } \\
\text { premise of this information } \\
\text { system is that more } \\
\text { information provided by a few } \\
\text { resources will improve } \\
\text { decision effectiveness and } \\
\text { resource utilization by orders } \\
\text { of magnitude. In today's } \\
\text { environment, RPp has a } \\
\text { complex information system } \\
\text { built on an antiquated network } \\
\text { of human procedures. } \\
\text { Although individual jobs seem } \\
\text { simpler than these "computer } \\
\text { systems," the total network of } \\
\text { human interaction in RPP is so } \\
\text { complex that adequate change } \\
\text { analysis is impossible, as is } \\
\text { timely and accurate reporting. } \\
\text { By implementing the liANDI } \\
\text { 2000 system and emphasizing } \\
\text { information quality, these } \\
\text { issues and associated costs } \\
\text { will be greatly reduced. } \\
\text { LMHC will change these } \\
\text { individuals' concerns through } \\
\text { training, procedures, } \\
\text { management support, and } \\
\text { discipline. } \\
\text { Yes, and the status } \\
\text { information can be accessed } \\
\text { through the Executive } \\
\text { Information System. See } \\
\text { Recommendation } 7.3 \text {. }\end{array}$ \\
\hline $\begin{array}{l}\text { 20. Documented and } \\
\text { approved Quality } \\
\text { Assurance } \\
\text { acceptance criteria } \\
(1.6-3.2)\end{array}$ & $\begin{array}{l}\text { HANDI } 2000 \\
\text { QC information about hold } \\
\text { points or other inspection } \\
\text { requirements may be entered as } \\
\text { information on work order }\end{array}$ & $\begin{array}{l}\text { HANDI 2000 } \\
\text { - QC information about } \\
\text { hold points or other } \\
\text { inspection requirements } \\
\text { may be entered on the QC }\end{array}$ & $\begin{array}{l}\text { HANDI } 2000 \\
\text { Inspection requirements } \\
\text { are specified for receipts. } \\
\text { The results (pass/fail) must } \\
\text { be entered into HANDI }\end{array}$ & $\begin{array}{l}\text { There are three products } \\
\text { required to enable a process } \\
\text { to be in place to capture } \\
\text { documented and approved } \\
\text { QA acceptance criteria: }\end{array}$ & $\begin{array}{l}\text { DOE owns Document } \\
\text { Mariagement, and LMHC } \\
\text { Systems Engineering will } \\
\text { submit an FY } 2000 \text { budget } \\
\text { request to procurc ECC and }\end{array}$ \\
\hline
\end{tabular}


Table 5-1. Maturity Assessment/Information Capability and Functionality Matrix.

\begin{tabular}{|c|c|c|c|c|c|}
\hline (a) & (b) & (c) & (d) & (e) & (f) \\
\hline $\begin{array}{l}\text { Information Need/ } \\
\text { Question Number }\end{array}$ & $\begin{array}{c}\text { General Description of System } \\
\text { Provisions }\end{array}$ & $\begin{array}{l}\text { PHMC HANDI } 2000 \text { System } \\
\text { Information } \\
\text { Capability }\end{array}$ & $\begin{array}{l}\text { PHMC HANDI } 2000 \text { System } \\
\text { Function } \\
\text { Capability }\end{array}$ & $\begin{array}{l}\text { User Comment on PHMC } \\
\text { HANDI } 2000 \text { Capability } \\
\left({ }^{*}\right)=\text { intend to resolve with } \\
\text { Interim Stabilization Pilot } \\
\text { Project }\end{array}$ & $\begin{array}{l}\text { SE\&I Response } \\
\text { to } \\
\text { User Comment }\end{array}$ \\
\hline . & $\begin{array}{l}\text { tasks, usage instructions on } \\
\text { catalog IDs (used at issue), and } \\
\text { purchase order receiving } \\
\text { instructions } \\
\text { The Document Management } \\
\text { and Engineering Change } \\
\text { Control modules of HANDI } \\
2000 \text { will provide a place to } \\
\text { link acceptance criteria } \\
\text { documents against specific } \\
\text { equipment locations, work } \\
\text { order tasks, action items, } \\
\text { design changes, projects, etc. }\end{array}$ & $\begin{array}{l}\text { panel on a work order } \\
\text { task. While there is no } \\
\text { functionality that ensures } \\
\text { that the direction is } \\
\text { followed, it does provide } \\
\text { a convenient space for } \\
\text { entering this information. } \\
\text { - Inspection criteria is listed } \\
\text { on Purchase orders to } \\
\text { direct the receipt } \\
\text { inspection of items } \\
\text { received at the } \\
\text { warehouse. } \\
\text { Inspection and testing } \\
\text { criteria may be added to } \\
\text { catalog IDs to be printed } \\
\text { at issue from the } \\
\text { warehouse. }\end{array}$ & $\begin{array}{l}2000 \text { before completion of } \\
\text { the receipt. } \\
\text { - Inspection/testing } \\
\text { requirements are printed } \\
\text { when parts are issued from } \\
\text { the warehouse for use in } \\
\text { the field. These } \\
\text { requirements are specified } \\
\text { on the catalog ID } \\
\text { definition panels. } \\
\text { - Work order tasks have a } \\
\text { specific panel for QC. } \\
\text { This panel is intended to } \\
\text { be used for listing QC hold } \\
\text { points or other QC } \\
\text { inspection instructions. }\end{array}$ & $\begin{array}{l}\text { (1) ECC, (2) Document } \\
\text { Management, and } \\
\text { (3) Curator. }\end{array}$ & $\begin{array}{l}\text { Curator, a document and } \\
\text { drawing change management } \\
\text { system. QA acceptance } \\
\text { criteria will be managed } \\
\text { through the HSTD } \\
\text { configuration management } \\
\text { functionality. See } \\
\text { Recommendation } 7.2 \text {. } \\
\text { QA documents will be routed, } \\
\text { approved, and managed using } \\
\text { the configuration management } \\
\text { system. See } \\
\text { Recommendations } 7.4 \text { and } 7.5 \text {. } \\
\text { The criteria will be tied to } \\
\text { work and actions through } \\
\text { linkage between the } \\
\text { configuration management } \\
\text { system and the work } \\
\text { management system. Sce } \\
\text { Recommendation } 7.2 \text {. }\end{array}$ \\
\hline $\begin{array}{l}\text { 21. Cost, resource, } \\
\text { schedule, and } \\
\text { technical risks- } \\
\text { identification, } \\
\text { analysis, and } \\
\text { mitigation } \\
(1.1-3.4,1.2-3.2, \\
1.7-1.1)\end{array}$ & $\begin{array}{l}\text { IIANDI } 2000 \\
\text { HANDI } 2000 \text { Project } \\
\text { Management provides the } \\
\text { ability to plan multiple versions } \\
\text { of cost and schedule plans. A } \\
\text { Notes panel is provided off of } \\
\text { cach version of a cost or } \\
\text { schedule plan that may be } \\
\text { linked via OLE to a document } \\
\text { such as a Microsoft }{ }^{\text {TM }} \text { Word } \\
\text { document or Microsoft } \\
\text { spreadsheet (any OLE- } \\
\text { compatible object). This } \\
\text { document may be used to } \\
\text { identify and assess the risks } \\
\text { and record how the version of } \\
\text { the cost of schedule plan } \\
\text { mitigates the risk assessment. }\end{array}$ & $\begin{array}{l}\text { HANDI } 2000 \\
\text { - Project Information } \\
\text { comments, notes, and } \\
\text { justification. } \\
\text { - Project cost plan notes. } \\
\text { - Project schedule plan } \\
\text { notes. }\end{array}$ & $\begin{array}{l}\text { HANDI } 2000 \\
\text { - Ability to add Project } \\
\text { Information scope, notes, } \\
\text { and justification via an } \\
\text { OLE document } \\
\text { attachment. } \\
\text { - Ability to add project cost } \\
\text { plan notes via OLE } \\
\text { document attachment. } \\
\text { - Ability to add project } \\
\text { schedule plan notes via } \\
\text { OLE document } \\
\text { attachment. }\end{array}$ & $\begin{array}{l}\text { Need an interface between } \\
\text { risk analysis software and } \\
\text { HANDI } 2000 \text { project } \\
\text { management. Need } \\
\text { agreement on standard risk } \\
\text { analysis software and basis } \\
\text { for use of risk analysis } \\
\text { results in setting up } \\
\text { cost/schedule variations. }\end{array}$ & $\begin{array}{l}\text { LMHC currently is reviewing } \\
\text { risk management systems that } \\
\text { will integrate with HSTD and } \\
\text { HANDI } 2000 \text { Project } \\
\text { Management, Work Control, } \\
\text { and Action Tracking modules. } \\
\text { See Recommendation } 7.6 \text { for } \\
\text { an interface design concept. }\end{array}$ \\
\hline
\end{tabular}


Table 5-1. Maturity Assessment/Information Capability and Functionality Matrix.

\begin{tabular}{|c|c|c|c|c|c|}
\hline (a) & (b) & (c) & (d) & (e) & (f) \\
\hline $\begin{array}{l}\text { Information Need/ } \\
\text { Question Number }\end{array}$ & $\begin{array}{l}\text { General Description of System } \\
\text { Provisions }\end{array}$ & $\begin{array}{l}\text { PHMC HANDI } 2000 \text { System } \\
\text { Information } \\
\text { Capability }\end{array}$ & $\begin{array}{l}\text { PHMC HANDI } 2000 \text { System } \\
\text { Function } \\
\text { Capability }\end{array}$ & $\begin{array}{c}\text { User Comment on PHMC } \\
\text { HANDI } 2000 \text { Capability } \\
\left({ }^{*}\right)=\text { intend to resolve with } \\
\text { Interim Stabilization Pilot } \\
\text { Project }\end{array}$ & $\begin{array}{l}\text { SE\&I Response } \\
\text { to } \\
\text { User Comment }\end{array}$ \\
\hline & $\begin{array}{l}\text { On the Project Information, } \\
\text { similar OLE functionality } \\
\text { exists for Project Comments } \\
\text { and Project Scope. In addition, } \\
\text { multiple Project Justifications } \\
\text { may be OLE attached to the } \\
\text { project. The Justifications may } \\
\text { be titled as technical risks, cost } \\
\text { risks, resource risks. and } \\
\text { schedule risks. The OLE- } \\
\text { attached document should } \\
\text { reflect the assessment and } \\
\text { mitigation of the risks } \\
\text { associated with the technical } \\
\text { aspects as well as the approved } \\
\text { cost and schedule plans. }\end{array}$ & & & & \\
\hline $\begin{array}{l}\text { 22. Visible to Project } \\
\text { Manager } \\
(1.7-1.3)\end{array}$ & $\frac{\text { HANDI } 2000}{\text { See items } 21 .}$ & $\frac{\text { HANDI } 2000}{\text { See items } 21 .}$ & $\frac{\text { HANDI } 2000}{\text { See items } 21 .}$ & $\begin{array}{l}\text { - Need a good reporting tool } \\
\text { and method or softwarc to } \\
\text { easily extract data in a } \\
\text { format that is readily } \\
\text { accessible to the manager. }\end{array}$ & $\begin{array}{l}\text { We will use the Exccutive } \\
\text { Information System for access } \\
\text { to management information. } \\
\text { See Recommendation 7.3. }\end{array}$ \\
\hline $\begin{array}{l}\text { 23. Risk thresholds } \\
(1.7-3.3)\end{array}$ & $\begin{array}{l}\text { HANDI } 2000 \\
\text { See item } 21 .\end{array}$ & $\frac{\text { HANDI 2000 }}{\text { See item 2l. }}$ & $\frac{\text { HANDI } 2000}{\text { See item } 21 .}$ & - See item 21 . & - See item 21 \\
\hline $\begin{array}{l}\text { 24. Risk Management } \\
\text { List } \\
(1.7-4.3) \\
\end{array}$ & $\frac{\text { HANDI 2000 }}{\text { See item 21. }}$ & $\frac{\text { HANDI } 2000}{\text { See item } 21 .}$ & $\frac{\text { HANDI } 2000}{\text { See item } 21 .}$ & - See item 21. & - See item 21 . \\
\hline $\begin{array}{l}\text { 25. Risks of different } \\
\text { system concepts } \\
\text { (alternatives) } \\
(3.1-1.4) \\
\end{array}$ & $\frac{\text { HANDI } 2000}{\text { See items } 21 \text { and } 40 .}$ & $\frac{\text { HANDI } 2000}{\text { See items } 21 \text { and } 40 .}$ & $\begin{array}{l}\text { HANDI } 2000 \\
\text { See items } 21 \text { and } 40 .\end{array}$ & - Sce item 21 & - Sec item 21 \\
\hline $\begin{array}{l}\text { 26. Technical } \\
\text { performance } \\
\text { measures-- } \\
\text { identified, } \\
\text { documented, and } \\
\text { distributed } \\
(1.2-3.5)\end{array}$ & $\begin{array}{l}\text { HANDI 2000 } \\
\text { While HANDI } 2000 \text { does not } \\
\text { contain specific data elements } \\
\text { or panels labeled "technical } \\
\text { performance measures," these } \\
\text { data may be identified in a } \\
\text { Justification document attached } \\
\text { to the Project Information. } \\
\text { Access to the HANDI } 2000 \\
\text { Project Management } \\
\text { information is controlled via }\end{array}$ & $\begin{array}{l}\text { HANDI 2000 } \\
\text { - AAA processing of } \\
\text { project approval. } \\
\text { - AAA notification of } \\
\text { authorization for } \\
\text { expenditure. } \\
\text { - Project Management } \\
\text { control of associated } \\
\text { object approval in Work } \\
\text { Management, Contracts, }\end{array}$ & $\begin{array}{l}\text { HANDI 2000 } \\
\text { - AAA notification to } \\
\text { project manager based on } \\
\text { project set alarms as } \\
\text { related to percent of costs } \\
\text { and schedule. } \\
\text { - Linkage of contracts to } \\
\text { project activities and } \\
\text { automatic update of } \\
\text { project as to contract costs } \\
\text { to date. }\end{array}$ & $\begin{array}{l}\text { HANDI } 2000 \text { metrics are } \\
\text { not a sufficient level of } \\
\text { sophistication. } \\
\\
\text { - Metrics/reports need a good } \\
\text { tool, then focus on metrics } \\
\text { is needed. Ensure the tool } \\
\text { provides easy and near- } \\
\text { time information without } \\
\text { significant people }\end{array}$ & $\begin{array}{l}\text { Technical performance } \\
\text { metrics can be established in } \\
\text { the HSTD at whatever level is } \\
\text { required. See } \\
\text { Recommendation } 7.2 \\
\text { - We will use the Executive } \\
\text { Information System for } \\
\text { general access to performance } \\
\text { measurement reports. See } \\
\text { Recommendation } 7.3 \text {. }\end{array}$ \\
\hline
\end{tabular}


Table 5-1. Maturity Assessment/Information Capability and Functionality Matrix.

\begin{tabular}{|c|c|c|c|c|c|}
\hline (a) & (b) & (c) & (d) & (e) & (f) \\
\hline \multirow[t]{2}{*}{$\begin{array}{l}\text { Information Need / } \\
\text { Question Number }\end{array}$} & $\begin{array}{l}\text { General Description of System } \\
\text { Provisions }\end{array}$ & $\begin{array}{l}\text { PHMC HANDI } 2000 \text { System } \\
\text { Information } \\
\text { Capability }\end{array}$ & $\begin{array}{l}\text { PHMC HANDI } 2000 \text { System } \\
\text { Function } \\
\text { Capability }\end{array}$ & $\begin{array}{l}\text { User Comment on PHMC } \\
\text { HANDI } 2000 \text { Capability } \\
\left(^{*}\right)=\text { intend to resolve with } \\
\text { Interim Stabilization Pilot } \\
\text { Project }\end{array}$ & $\begin{array}{l}\text { SE\&I Response } \\
\text { to } \\
\text { User Comment }\end{array}$ \\
\hline & $\begin{array}{l}\text { rules defined by the project } \\
\text { manager. Additional personnel } \\
\text { may be notified at various } \\
\text { project stages via AAA } \\
\text { messages (e.g.. authorization } \\
\text { for approval, informational } \\
\text { routing, notification of } \\
\text { authorization of expenditure, } \\
\text { approaching defined percent of } \\
\text { budget). } \\
\text { Benchmarking of processes is } \\
\text { not performed in HANDI } 2000 \text {. }\end{array}$ & and Inventory modules. & $\begin{array}{l}\text { Project plans may be } \\
\text { submitted for approval } \\
\text { using the standard HANDI } \\
2000 \text { routing features } \\
\text { using AAA messages to } \\
\text { notify the project initiator } \\
\text { if the package has been } \\
\text { rejected or returned. } \\
\text { - Supports the creation and } \\
\text { approval routing of an } \\
\text { authorization for } \\
\text { expenditure. }\end{array}$ & $\begin{array}{l}\text { involvement in generation } \\
\text { of metric/report. }\end{array}$ & \\
\hline $\begin{array}{l}\text { 27. Technical } \\
\text { Performance } \\
\text { Measurement } \\
\text { Assessment Plan } \\
(1.2-4.2)\end{array}$ & $\begin{array}{l}\text { HANDI } 2000 \text { - } \\
\text { If the Technical Performance } \\
\text { Assessment Plan is a document } \\
\text { that is living and should be } \\
\text { attached to the project, it may } \\
\text { be attached to the Project } \\
\text { Information as a Justification } \\
\text { document. The Justification(s) } \\
\text { attached to the HANDI } 2000 \\
\text { project may each be titled by } \\
\text { the project manager and may be } \\
\text { OLE linked to a Microsoft } \mathrm{T}^{\mathrm{TM}} \\
\text { Word document or Microsoft } \\
\text { Excel spreadshcet (any OLE- } \\
\text { compliant object). } \\
\text { If the Technical Performance } \\
\text { Assessment Plan is a document } \\
\text { that is not controlled by the } \\
\text { project, it may be referenced on } \\
\text { the Project Information } \\
\text { Document Reference panel. }\end{array}$ & $\begin{array}{l}\text { HANDI 2000 } \\
\text { - Project justification } \\
\text { documents (OLE linking } \\
\text { available). } \\
\text { - Project document } \\
\text { references. }\end{array}$ & $\begin{array}{l}\text { - Ability to create the } \\
\text { Technical Performance } \\
\text { Measurement Assessment } \\
\text { Plan in Microsoft }{ }^{\mathrm{M}} \text { Word } \\
\text { or another OLE object and } \\
\text { to control access and } \\
\text { update to the document } \\
\text { through Project } \\
\text { Management. } \\
\text { - Ability to access } \\
\text { controlled documents and } \\
\text { records and to reference } \\
\text { them on the project } \\
\text { information. }\end{array}$ & $\begin{array}{l}\text { Metrics should be at } \\
\text { several different levels. } \\
\text { Metrics should be tailored } \\
\text { to the purpose of the } \\
\text { organization. Metrics } \\
\text { should be reduced to a } \\
\text { necessary and sufticient } \\
\text { level that allows detailed } \\
\text { assessment by the } \\
\text { organization. }\end{array}$ & $\begin{array}{l}\text { See Recommendations } 7.2 \text { and } \\
\text { 7.5. Technical performance } \\
\text { metrics can be established in } \\
\text { the HSTD at whatever level is } \\
\text { required. The assessments } \\
\text { become reports that are } \\
\text { viewed through the Executive } \\
\text { Information System. }\end{array}$ \\
\hline $\begin{array}{l}\text { 28. Master } \\
\text { Measurement List } \\
(1.2-4.3)\end{array}$ & $\begin{array}{l}\text { HANDI } 2000 \\
\text { If the Master Measurement List } \\
\text { is a document that is living and } \\
\text { should be attached to the } \\
\text { project, it may be attached to } \\
\text { the Project Information as a }\end{array}$ & $\begin{array}{l}\text { HANDI 2000 } \\
\text { - Project justification } \\
\text { documents (OLE linking } \\
\text { available). } \\
\text { - Project document } \\
\text { references. }\end{array}$ & $\begin{array}{l}\text { HANDI } 2000 \\
\text { Ability to create the } \\
\text { Master Measurement List } \\
\text { in Microsoft } \\
\text { another Word or } \\
\text { control access and update }\end{array}$ & - See items 26 and 27. & - See items 26 and 27 \\
\hline
\end{tabular}


Table 5-1. Maturity Assessment/Information Capability and Functionality Matrix.

\begin{tabular}{|c|c|c|c|c|c|}
\hline (a) & (b) & (c) & (d) & (e) & (f) \\
\hline $\begin{array}{l}\text { Information Need / } \\
\text { Question Number }\end{array}$ & $\begin{array}{c}\text { General Description of System } \\
\text { Provisions }\end{array}$ & $\begin{array}{l}\text { PHMC HANDI } 2000 \text { System } \\
\text { Information } \\
\text { Capability }\end{array}$ & $\begin{array}{l}\text { PHMC HANDI } 2000 \text { System } \\
\text { Function } \\
\text { Capability }\end{array}$ & $\begin{array}{l}\text { User Comment on PHMC } \\
\text { HANDI } 2000 \text { Capability } \\
\left({ }^{*}\right)=\text { intend to resolve with } \\
\text { Interim Stabilization Pilot } \\
\text { Project }\end{array}$ & $\begin{array}{c}\text { SE\&I Response } \\
\text { to } \\
\text { User Comment }\end{array}$ \\
\hline & $\begin{array}{l}\text { Justification document. The } \\
\text { Justification(s) attached to the } \\
\text { HANDI } 2000 \text { Project may each } \\
\text { be titled by the project manager } \\
\text { and may be OLE linked to a } \\
\text { Microsof }{ }^{\mathrm{TM}} \text { Word document or } \\
\text { Microsof }^{\mathrm{TM}} \text { Excel spreadsheet } \\
\text { (any OLE-compliant object). } \\
\\
\text { If the Master Measurement List } \\
\text { is a document that is not } \\
\text { controlled by the project, it } \\
\text { may be referenced on the } \\
\text { Project Information Document } \\
\text { Reference panel. }\end{array}$ & & $\begin{array}{l}\text { to the document through } \\
\text { Project Management. } \\
\text { Ability to access } \\
\text { controlled documents and } \\
\text { records and to reference } \\
\text { them on the Project } \\
\text { Information. }\end{array}$ & & \\
\hline $\begin{array}{l}\text { 29. Archiving/ } \\
\text { retrieving Project } \\
\text { Information } \\
(1.8-1.2)\end{array}$ & $\begin{array}{l}\text { HANDI } 2000 \\
\text { The data associated with a } \\
\text { project in HANDI } 2000 \text { may } \\
\text { include many objects (e.g., } \\
\text { work orders, work requests, } \\
\text { contracts, engineering changes, } \\
\text { action items, material requests, } \\
\text { issues, invoices). } \\
\text { Archive programs are designed } \\
\text { to archive and purge all related } \\
\text { tables in a business data object } \\
\text { (e.g., a purchase order) that } \\
\text { meet the specified criteria. The } \\
\text { object must mect archive } \\
\text { criteria (a set of conditions) in } \\
\text { order to consider the data } \\
\text { object for archive. An archive } \\
\text { period parameter is sct by the } \\
\text { user (during the on-line job } \\
\text { launch or via a system } \\
\text { preference) to indicate the } \\
\text { length of time that they want } \\
\text { the data object retained on-line } \\
\text { after all other archive criteria } \\
\text { are met. }\end{array}$ & $\begin{array}{l}\text { HANDI } 2000 \\
\text { The following objects in } \\
\text { HANDI } 2000 \text { may be } \\
\text { archived. } \\
\text { - Checks. } \\
\text { - Invoices. } \\
\text { - Action request. } \\
\text { - Audit data. } \\
\text { - Distributions. } \\
\text { - Issues. } \\
\text { - Material request. } \\
\text { - Putaway. } \\
\text { - Passbook data audit. } \\
\text { - Purchase orders. } \\
\text { - AAA messages. } \\
\text { - Request for quotations. } \\
\text { - Receipts. } \\
\text { - Purchase requisitions. } \\
\text { - Transfers. } \\
\text { - Timeshects. } \\
\text { - Transmittals. } \\
\text { - Work orders. } \\
\text { - Work requests. }\end{array}$ & $\begin{array}{l}\text { HANDI } 2000 \\
\text { - Archive processing. } \\
\text { - Restart processing. } \\
\text { - Back out processing. } \\
\text { Automatic archiving (of } \\
\text { some objects). } \\
\text { - Ability to report against } \\
\text { archive tables. }\end{array}$ & $\begin{array}{l}\text { - Criteria for what is } \\
\text { archived/retrievable need to } \\
\text { be clearer. }\end{array}$ & $\begin{array}{l}\text { - This is a function of the } \\
\text { HANDI } 2000 \text { data } \\
\text { management plan developed } \\
\text { under the HANDI } 2000 \\
\text { project. }\end{array}$ \\
\hline
\end{tabular}


Table 5-1. Maturity Assessment/Information Capability and Functionality Matrix.

\begin{tabular}{|c|c|c|c|c|c|}
\hline (a) & (b) & (c) & (d) & (e) & (f) \\
\hline $\begin{array}{l}\text { Information Need / } \\
\text { Question Number }\end{array}$ & $\begin{array}{c}\text { General Description of System } \\
\text { Provisions }\end{array}$ & $\begin{array}{l}\text { PHMC HANDI } 2000 \text { System } \\
\text { Information } \\
\text { Capability }\end{array}$ & $\begin{array}{l}\text { PHMC HANDI } 2000 \text { System } \\
\text { Function } \\
\text { Capability }\end{array}$ & $\begin{array}{c}\text { User Comment on PHMC } \\
\text { HANDI } 2000 \text { Capability } \\
(*)=\text { intend to resolve with } \\
\text { Interim Stabilization Pilot } \\
\text { Project }\end{array}$ & $\begin{array}{l}\text { SE\&I Response } \\
\text { to } \\
\text { User Comment }\end{array}$ \\
\hline & $\begin{array}{l}\text { Archived data are written to } \\
\text { archive tables that exactly } \\
\text { mirror their respective on-line } \\
\text { table. These tables are not } \\
\text { accessed by the on-line system } \\
\text { but can be used for reporting. } \\
\text { All archive tables have a prefix } \\
\text { of TIA followed by the table } \\
\text { name. Once data are archived, } \\
\text { they are purged from the on- } \\
\text { line tables. The archive } \\
\text { programs produce a report } \\
\text { listing the keys of the data } \\
\text { objects that were purged in the } \\
\text { run. The key data reflects the } \\
\text { key of the head table for the } \\
\text { object. } \\
\text { PeopleSoft } \\
\text { to archive and retrieve project } \\
\text { data from previous years/ } \\
\text { project life cycles. This } \\
\text { retricval includes accessibility } \\
\text { to all PeopleSoft } \\
\text { TM objects. } \\
\text { HANDI } 2000 \text { has the ability to } \\
\text { archive previous year data back } \\
\text { to } 1997 \text {. This includes project- } \\
\text { to-date data (i.e., budget, } \\
\text { performance, and actuals). }\end{array}$ & T= & $\because$ & 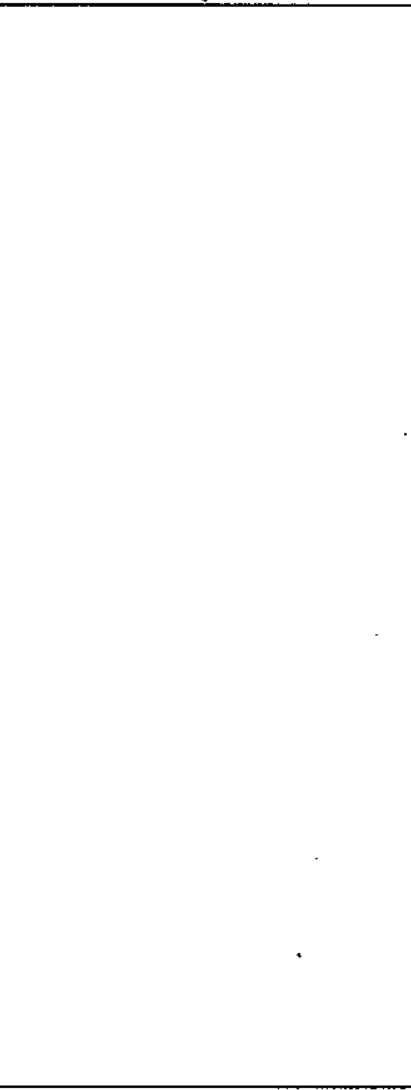 & \\
\hline $\begin{array}{l}\text { 30. } \text { Relationships } \\
\text { between } \\
\text { requirements and } \\
\text { interface } \\
\text { documents } \\
\text { (specification } \\
\text { tree) } \\
(1.8-1.3)\end{array}$ & $\begin{array}{l}\text { HANDI } 2000 \\
\text { The integrated suite of HANDI } \\
2000 \text { products allows the } \\
\text { documents stored and managed } \\
\text { in the Controlled Documents } \\
\text { and Records Management } \\
\text { modules to be referenced on } \\
\text { most other HANDI } 2000 \\
\text { objects. While HANDI } 2000 \\
\text { docs not have a "Specification } \\
\text { Tree." it is possible to create a }\end{array}$ & $\begin{array}{l}\text { HANDI 2000 } \\
\text { - Document references on } \\
\text { action items. } \\
\text { - Document references on } \\
\text { equipment locations. } \\
\text { - Document references on } \\
\text { othcr documents. } \\
\text { - Document references on } \\
\text { engineering changes. } \\
\text { - Affected documents list } \\
\text { on engineering changes. }\end{array}$ & $\begin{array}{l}\text { HANDI } 2000 \\
\text { - Ability to reference } \\
\text { documents on all of the } \\
\text { above listed HANDI } 2000 \\
\text { objects. } \\
\text { - Ability to write reports } \\
\text { that can represent a } \\
\text { "Specification Tree" of } \\
\text { related documents (and } \\
\text { HANDI } 2000 \text { objects } \\
\text { affected). }\end{array}$ & $\begin{array}{l}\text { Curator, Document } \\
\text { Management, ECC, and } \\
\text { Procurement Engineering } \\
\text { products are needed to } \\
\text { resolve current difficulty in } \\
\text { retrieval and use of } \\
\text { documents. }\end{array}$ & $\begin{array}{l}\text { LMHC Systems Engineering } \\
\text { will submit an FY } 2000 \\
\text { budget request for the } \\
\text { Procurement Engineering } \\
\text { module. HSTD will contain } \\
\text { the traceability of } \\
\text { requirements to ICDs. See } \\
\text { Recommendation } 7.2 \text {. ICDs } \\
\text { will be released and } \\
\text { configuration managed using } \\
\text { the configuration management }\end{array}$ \\
\hline
\end{tabular}


Table 5-1. Maturity Assessment/Information Capability and Functionality Matrix.

\begin{tabular}{|c|c|c|c|c|c|}
\hline (a) & (b) & (c) & (d) & (e) & (f) \\
\hline $\begin{array}{l}\text { Information Need / } \\
\text { Question Number }\end{array}$ & $\begin{array}{c}\text { General Description of System } \\
\text { Provisions }\end{array}$ & $\begin{array}{l}\text { PHMC HANDI } 2000 \text { System } \\
\text { Information } \\
\text { Capability }\end{array}$ & $\begin{array}{l}\text { PHMC HANDI } 2000 \text { System. } \\
\text { Function } \\
\text { Capability }\end{array}$ & $\begin{array}{c}\text { User Comment on PHMC } \\
\text { HANDI } 2000 \text { Capability } \\
\left(^{*}\right)=\text { intend to resolve with } \\
\text { Interim Stabilization Pilot } \\
\text { Project }\end{array}$ & $\begin{array}{c}\text { SE\&I Response } \\
\text { to } \\
\text { User Comment }\end{array}$ \\
\hline . & $\begin{array}{l}\text { report that will show all } \\
\text { HANDI } 2000 \text { objects that } \\
\text { reference a particular } \\
\text { document. } \\
\text { The Equipment Data module in } \\
\text { Work Management is very } \\
\text { tightly integrated with the } \\
\text { Engineering Change module } \\
\text { and the Controlled Documents } \\
\text { module. From the Controlled } \\
\text { Documents module, there is } \\
\text { on-line functionality that lists } \\
\text { all equipment locations that } \\
\text { reference the document and all } \\
\text { engineering changes that affect } \\
\text { the document. Engineering } \\
\text { changes list the affect } \\
\text { equipment locations and the } \\
\text { affected documents. }\end{array}$ & $\begin{array}{l}\text { Document references on } \\
\text { work requests. } \\
\text { - Document references on } \\
\text { work order task packages. } \\
\text { - Document references on } \\
\text { project information. } \\
\text { - Document references on } \\
\text { uniquely tracked } \\
\text { commodities. } \\
\text { - Document references on } \\
\text { bill of materials. }\end{array}$ & $\begin{array}{l}\text { Ability to automatically } \\
\text { pull document references } \\
\text { from the equipment data to } \\
\text { work requests and then to } \\
\text { work order tasks. } \\
\text { Ability to determine that } \\
\text { there is an engineering } \\
\text { change that affects a } \\
\text { document in the } \\
\text { Controlled Documents } \\
\text { module. }\end{array}$ & & $\begin{array}{l}\text { system. See } \\
\text { Recommendation } 7.4 \text {. }\end{array}$ \\
\hline $\begin{array}{l}\text { 31. Relationships } \\
\text { between drawings } \\
\text { of physical } \\
\text { elements of the } \\
\text { system (drawing } \\
\text { tree) }(1.8-1.4)\end{array}$ & $\frac{\text { HANDI } 2000}{\text { See item } 31 .}$ & $\frac{\text { HANDI } 2000}{\text { See item } 31 .}$ & $\frac{\text { HANDI } 2000}{\text { See item } 31 .}$ & $\begin{array}{l}\text { Curator, Document } \\
\text { Management, ECC, and } \\
\text { Procurement Engineering } \\
\text { products are needed to } \\
\text { resolve current difficulty in } \\
\text { retrieval and use of } \\
\text { documents. }\end{array}$ & $\begin{array}{l}\text { See Recommendation } 7.4 \text {. } \\
\text { The drawing relationships are } \\
\text { established and maintained in } \\
\text { the configuration management } \\
\text { system. }\end{array}$ \\
\hline $\begin{array}{l}\text { 32. Relationships } \\
\text { between software } \\
\text { clements and } \\
\text { interfaces } \\
(1.8-1.5)\end{array}$ & $\begin{array}{l}\text { HANDI } 2000 \\
\text { HANDI } 2000 \text { does not provide } \\
\text { this functionality. }\end{array}$ & $\begin{array}{l}\text { HANDI } 2000 \\
\text { HANDI } 2000 \text { does not } \\
\text { provide this functionality. }\end{array}$ & $\begin{array}{l}\text { HANDI } 2000 \\
\text { HANDI } 2000 \text { does not } \\
\text { provide this functionality. }\end{array}$ & $\begin{array}{l}\text { Tank farm monitoring and } \\
\text { control systems need to } \\
\text { address this requirement. }\end{array}$ & $\begin{array}{l}\text { See Recommendation } 7.2 \text { for } \\
\text { the use of HSTD in specifying } \\
\text { and managing these } \\
\text { relationships. }\end{array}$ \\
\hline $\begin{array}{l}\text { 33. Status of Project } \\
\text { Information (at } \\
\text { any given time) } \\
(1.8-3.4)\end{array}$ & $\begin{array}{l}\text { HANDI } 2000 \\
\text { Each project is controlled (via } \\
\text { approvals of the completion of } \\
\text { work) through a series of status } \\
\text { changes. These status changes } \\
\text { are visible to anyone with } \\
\text { access to the Project } \\
\text { Management module of } \\
\text { HANDI } 2000 \text {. The other }\end{array}$ & $\frac{\text { HANDI } 2000}{\text { See item } 15 .}$ & $\frac{\text { HANDI } 2000}{\text { See item } 15 .}$ & $\begin{array}{l}\text { Need to address the Project } \\
\text { Management and Business } \\
\text { Management boundaries } \\
\text { shifting the process for } \\
\text { approvals to Project } \\
\text { Control vs. BMS. This } \\
\text { should be done at a level in } \\
\text { the WBS that makes sense } \\
\text { (i.e., baseline change }\end{array}$ & $\begin{array}{l}\text { The implementation of } \\
\text { HANDI } 2000 \text { Project } \\
\text { Management and related } \\
\text { procedures will place BCR } \\
\text { responsibility authority on } \\
\text { project managers. The Project } \\
\text { Management entries will form } \\
\text { the baseline and source for } \\
\text { subsequent change. PHMC is }\end{array}$ \\
\hline
\end{tabular}


Table 5-1. Maturity Assessment/Information Capability and Functionality Matrix.

\begin{tabular}{|c|c|c|c|c|c|}
\hline (a) & (b) & (c) & (d) & (e) & (f) \\
\hline $\begin{array}{l}\text { Information Need / } \\
\text { Question Number }\end{array}$ & $\begin{array}{c}\text { General Description of System } \\
\text { Provisions }\end{array}$ & $\begin{array}{l}\text { PHMC HANDI } 2000 \text { System } \\
\text { Information } \\
\text { Capability }\end{array}$ & $\begin{array}{l}\text { PHMC HANDI 2000 System } \\
\text { Function } \\
\text { Capability }\end{array}$ & $\begin{array}{c}\text { User Comment on PHMC } \\
\text { HANDI } 2000 \text { Capability } \\
\left({ }^{*}\right)=\text { intend to resolve with } \\
\text { Interim Stabilization Pilot } \\
\text { Project }\end{array}$ & $\begin{array}{l}\text { SE\&I Response } \\
\text { to } \\
\text { User Comment }\end{array}$ \\
\hline & $\begin{array}{l}\text { HANDI } 2000 \text { objects that } \\
\text { manage the work associated } \\
\text { with the project also are } \\
\text { controlled via a series of status } \\
\text { changes. These associated } \\
\text { HANDI } 2000 \text { objects include } \\
\text { work requests, action items, } \\
\text { engineering changes, work } \\
\text { orders, document references, } \\
\text { ctc. See item } 15 \text {. }\end{array}$ & . & & $\begin{array}{l}\text { control processes do not } \\
\text { currently support electronic } \\
\text { workflow and approval). } \\
\text { - People doing work are not } \\
\text { currently inputting status } \\
\text { daily (i.e., hours applied } \\
\text { and/or hours remaining). }\end{array}$ & $\begin{array}{l}\text { currently testing the workflow } \\
\text { capability of the Project } \\
\text { Management module. } \\
\text { - The system allows daily status } \\
\text { input; this is a procedural and } \\
\text { management issuc. The Work } \\
\text { Management project is } \\
\text { determining the actual } \\
\text { requirement for status } \\
\text { reporting. If daily input is } \\
\text { required, then the new } \\
\text { procedures will reflect that. } \\
\text { The direct and real-time input } \\
\text { of status by end users, } \\
\text { including employees, } \\
\text { contractors, and procurements, } \\
\text { rather than intermediaries, } \\
\text { coupled with the HANDI } 2000 \\
\text { system's inherent integration } \\
\text { of production data and } \\
\text { financial, provide accurate } \\
\text { quality status sufficient for the } \\
\text { RPP. }\end{array}$ \\
\hline $\begin{array}{l}\text { 34. Concurrent } \\
\text { engineering } \\
\text { information is } \\
\text { passed between } \\
\text { the groups } \\
\text { involved in } \\
\text { concurrent } \\
\text { engineering. } \\
\text { (All of } \\
\text { Section 1.4) }\end{array}$ & $\begin{array}{l}\text { HANDI } 2000 \\
\text { HANDI } 2000 \text { ECC provides } \\
\text { the control mechanisms that } \\
\text { allow concurrent engineering. } \\
\text { A key aspect of the HANDI } \\
2000 \text { solution is that the } \\
\text { concurrent engineering } \\
\text { information is not required to } \\
\text { be passed between groups. All } \\
\text { design work associated with a } \\
\text { facility that is processed using } \\
\text { HANDI } 2000 \text { ECC, Document } \\
\text { Management, and Work } \\
\text { Management is available to all } \\
\text { groups concurrently. If there is } \\
\text { an overlap in work on a } \\
\text { document, drawing, or } \\
\text { equipment location, for }\end{array}$ & $\begin{array}{l}\text { HANDI 2000 } \\
\text { - Engineering change } \\
\text { linkage to an action } \\
\text { tracking assignment. } \\
\text { - Pending engineering } \\
\text { changes. } \\
\text { - Engineering change } \\
\text { affected documents list. } \\
\text { - Engineering change } \\
\text { affected cquipment list. } \\
\text { - HANDI } 2000 \text { cross } \\
\text { reference. } \\
\text { - Engineering change } \\
\text { milestones. }\end{array}$ & $\begin{array}{l}\text { HANDI } 2000 \\
\text { Ability to initiate an } \\
\text { engineering change as a } \\
\text { result of an action tracking } \\
\text { assignment. } \\
\text { - Ability to list all } \\
\text { equipmcnt locations } \\
\text { affected by an engineering } \\
\text { change. } \\
\text { - Ability to access all } \\
\text { pending engineering } \\
\text { changes applicable to an } \\
\text { equipment location. } \\
\text { - Ability to list all } \\
\text { documents affected by an } \\
\text { engineering change. } \\
\text { - Ability to list all pending } \\
\text { enginecring changes }\end{array}$ & $\begin{array}{l}\text { - Curator, Document } \\
\text { Management, and ECC } \\
\text { products are needed } \\
\text { because the current process } \\
\text { is very costly and very } \\
\text { slow. }\end{array}$ & $\begin{array}{l}\text { See Recommendations } 7.4 \\
\text { and } 7.5 \text { for the description of } \\
\text { how the Configuration } \\
\text { Management system monitors } \\
\text { changes to interfaces and } \\
\text { routes changes to cognizant } \\
\text { engineers whose } \\
\text { configurations are affected by } \\
\text { change. }\end{array}$ \\
\hline
\end{tabular}


Table 5-1. Maturity Assessment/Information Capability and Functionality Matrix.

\begin{tabular}{|c|c|c|c|c|c|}
\hline (a) & (b) & (c) & (d) & (e) & (f) \\
\hline $\begin{array}{l}\text { Information Need / } \\
\text { Question Number }\end{array}$ & $\begin{array}{l}\text { General Description of System } \\
\text { Provisions }\end{array}$ & $\begin{array}{l}\text { PHMC HANDI } 2000 \text { System } \\
\text { Information } \\
\text { Capability }\end{array}$ & $\begin{array}{l}\text { PHMC HANDI } 2000 \text { System } \\
\text { Function } \\
\text { Capability }\end{array}$ & $\begin{array}{c}\text { User Comment on PHMC } \\
\text { HANDI } 2000 \text { Capability } \\
\left({ }^{*}\right)=\text { intend to resolve with } \\
\text { Interim Stabilization Pilot } \\
\text { Project }\end{array}$ & $\begin{array}{l}\text { SE\&I Response } \\
\text { to } \\
\text { User Comment }\end{array}$ \\
\hline . & $\begin{array}{l}\text { example, the other engineer's } \\
\text { work in progress will be } \\
\text { obvious to the first engineer. } \\
\text { Furthermore, the first engineer } \\
\text { may access the other engineer's } \\
\text { work in progress to assess the } \\
\text { impact. } \\
\text { The HANDI } 2000 \text { Engineering } \\
\text { Change system is fully } \\
\text { integrated with the Document } \\
\text { Management, Work } \\
\text { Managenent, Action Tracking, } \\
\text { and Procurement Engineering } \\
\text { systems to ensure that work } \\
\text { requirements associated with } \\
\text { the change are identified and } \\
\text { completed. } \\
\text { The HANDI } 2000 \text { Engineering } \\
\text { Change system is fully } \\
\text { integrated with the equipment } \\
\text { database containcd within the } \\
\text { Work Management system. } \\
\text { Thus, pending changes against } \\
\text { cquipment will be recorded in } \\
\text { the same database as all other } \\
\text { physical equipment data (e.g., } \\
\text { repairs, preventive } \\
\text { maintenance, bill of materials). } \\
\text { Revision tracking and control } \\
\text { are available and, if activated, } \\
\text { will highlight pending changes } \\
\text { upon display of the equipment } \\
\text { location. }\end{array}$ & . & $\begin{array}{l}\text { affecting a controlled } \\
\text { document. } \\
\text { Ability to route } \\
\text { engineering changes for } \\
\text { review and approval. }\end{array}$ & 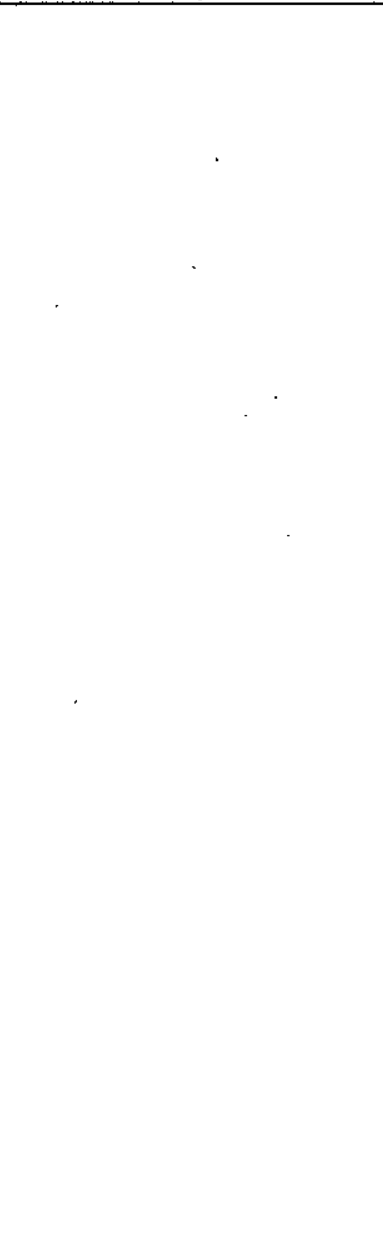 & \\
\hline $\begin{array}{l}\text { 35. Interfaces } \\
\text { identified/ } \\
\text { managed } \\
(3.5-3.3)\end{array}$ & $\begin{array}{l}\text { HANDI } 2000 \\
\text { HANDI } 2000 \text { does not provide } \\
\text { this functionality. }\end{array}$ & $\begin{array}{l}\text { HANDI } 2000 \\
\text { HANDI } 2000 \text { does not } \\
\text { provide this functionality. }\end{array}$ & $\begin{array}{l}\text { HANDI } 2000 \\
\text { HANDI } 2000 \text { does not } \\
\text { provide this functionality. }\end{array}$ & $\begin{array}{l}\text { Need to adapt work } \\
\text { processes to use Curator, } \\
\text { Document Management, } \\
\text { ECC, Action Tracking, } \\
\text { Project Management, and } \\
\text { Work Control products to }\end{array}$ & $\begin{array}{l}\text { Interface requirements are } \\
\text { identified and managed using } \\
\text { the HSTD. See } \\
\text { Recommendation 7.2. Sce } \\
\text { Recommendations } 7.4 \text { and } 7.5 \\
\text { for the description of how the }\end{array}$ \\
\hline
\end{tabular}


Table 5-1. Maturity Assessment/Information Capability and Functionality Matrix.

\begin{tabular}{|c|c|c|c|c|c|}
\hline (a) & (b) & (c) & (d) & (e) & (f) \\
\hline $\begin{array}{l}\text { Information Need / } \\
\text { Question Number }\end{array}$ & $\begin{array}{c}\text { General Description of System } \\
\text { Provisions }\end{array}$ & $\begin{array}{l}\text { PHMC HANDI } 2000 \text { System } \\
\text { Information } \\
\text { Capability }\end{array}$ & $\begin{array}{l}\text { PHMC HANDI } 2000 \text { System } \\
\text { Function } \\
\text { Capability? }\end{array}$ & $\begin{array}{c}\text { User Comment on PHMC } \\
\text { HANDI } 2000 \text { Capability } \\
(*)=\text { intend to resolve with } \\
\text { Interim Stabilization Pilot } \\
\text { Project }\end{array}$ & $\begin{array}{l}\text { SE\&I Response } \\
\text { to } \\
\text { User Comment }\end{array}$ \\
\hline & & & & $\begin{array}{l}\text { meet the need of interface } \\
\text { management and ICDs. }\end{array}$ & $\begin{array}{l}\text { configuration management } \\
\text { system monitors changes to } \\
\text { interfaces and routes changes } \\
\text { to cognizant engineers whose } \\
\text { configurations are affected by } \\
\text { change. }\end{array}$ \\
\hline $\begin{array}{l}\text { 36. Interface Control } \\
\text { Documents } \\
(3.5-4.2)\end{array}$ & $\begin{array}{l}\text { HANDI } 2000 \\
\text { HANDI } 2000 \text { does not provide } \\
\text { this functionality. }\end{array}$ & $\begin{array}{l}\text { HANDI } 2000 \\
\text { HANDI } 2000 \text { does not } \\
\text { provide this functionality. }\end{array}$ & $\begin{array}{l}\text { HANDI } 2000 \\
\text { HANDI } 2000 \text { does not } \\
\text { provide this functionality. }\end{array}$ & $\begin{array}{l}\text { Need to adapt work } \\
\text { processes to use Curator, } \\
\text { Document Management, } \\
\text { ECC, Action Tracking, } \\
\text { Project Management, and } \\
\text { Work Control products to } \\
\text { meet the need of interface. } \\
\text { management and ICDs. }\end{array}$ & $\begin{array}{l}\text { See Recommendations } 7.4 \text { and } \\
7.5 \text { for the description of how } \\
\text { the configuration management } \\
\text { system manages documents, } \\
\text { monitors changes to } \\
\text { interfaces, and routes changes } \\
\text { to cognizant engineers whose } \\
\text { configurations are affected by } \\
\text { change. }\end{array}$ \\
\hline $\begin{array}{l}\text { 37. Technical } \\
\text { Management Plan } \\
\text { (Systems } \\
\text { Engineering } \\
\text { Management } \\
\text { Plan) } \\
(1.1-2.2)\end{array}$ & $\begin{array}{l}\text { HANDI 2000 } \\
\text { Documentation of the } \\
\text { Technical Management Plan } \\
\text { for a project may be attached as } \\
\text { a document to the HANDI } \\
2000 \text { Project Management Data } \\
\text { pancls used to describe the } \\
\text { project. HANDI } 2000 \text { Project } \\
\text { Management allows the } \\
\text { creation of multiple cost and } \\
\text { schedule plans, which allows } \\
\text { the project manager to } \\
\text { document several 'what-if' } \\
\text { scenarios for a project. } \\
\text { HANDI 2000 Project } \\
\text { Management requires that a } \\
\text { combination of cost and } \\
\text { schedule plans be selected and } \\
\text { approved before proceeding. }\end{array}$ & $\begin{array}{l}\text { HANDI } 2000 \\
\text { - Project definition data. } \\
\text { - Project justification. } \\
\text { - Project schedule data. } \\
\text { - Project budget data. }\end{array}$ & $\begin{array}{l}\text { HANDI } 2000 \\
\text { - Ability to define and save } \\
\text { cost and schedule } \\
\text { scenarios for a project and } \\
\text { to proceed with the } \\
\text { selected plan. } \\
\text { - The Technical } \\
\text { Management Plan may be } \\
\text { attached to the project as a } \\
\text { document reference or an } \\
\text { OLE-attached document in } \\
\text { Scope or Notes. } \\
\text { - The activities of each } \\
\text { enginecring specialty can } \\
\text { be assigned using the } \\
\text { HANDI } 2000 \text { Action } \\
\text { Tracking module, } \\
\text { scheduled in the Project } \\
\text { Management module, and } \\
\text { fed to the Microsoft } \\
\text { Project }{ }^{T M} \text { schedule. } \\
\text { - Work order task package } \\
\text { activities associated with } \\
\text { the project are managed in } \\
\text { the Work Management } \\
\text { module, which provides an }\end{array}$ & $\begin{array}{l}\text { - HANDI } 2000 \text { does not } \\
\text { enforce the technical } \\
\text { management plan. }\end{array}$ & $\begin{array}{l}\text { See Recommendation } 7.5 \text { for } \\
\text { the ideas on how either } \\
\text { HANDI } 2000 \text { or the } \\
\text { configuration management } \\
\text { system can ensure that a } \\
\text { disciplined system engineering } \\
\text { process is applied. }\end{array}$ \\
\hline
\end{tabular}


Table 5-1. Maturity Assessment/Information Capability and Functionality Matrix.

\begin{tabular}{|c|c|c|c|c|c|}
\hline (a) & (b) & (c) & (d) & (e) & (f) \\
\hline \multirow[t]{2}{*}{$\begin{array}{l}\text { Information Need/ } \\
\text { Question Number }\end{array}$} & $\begin{array}{l}\text { General Description of System } \\
\text { Provisions }\end{array}$ & $\begin{array}{l}\text { PHMC HANDI } 2000 \text { System } \\
\text { Information } \\
\text { Capability }\end{array}$ & $\begin{array}{l}\text { PHMC HANDI } 2000 \text { System } \\
\text { Function } \\
\text { Capability }\end{array}$ & $\begin{array}{c}\text { User Comment on PHMC } \\
\text { HANDI } 2000 \text { Capability } \\
\left(^{*}\right)=\text { intend to resolve with } \\
\text { Interim Stabilization Pilot } \\
\text { Project }\end{array}$ & $\begin{array}{l}\text { SE\&I Response } \\
\text { to } \\
\text { User Comment }\end{array}$ \\
\hline & & & $\begin{array}{l}\text { interface to P3 or to } \\
\text { Microsoft Project } \\
\text { schedule management. } \\
\text { - Project plans may be } \\
\text { submitted for approval } \\
\text { using the standard HANDI } \\
2000 \text { routing features } \\
\text { using AAA messages to } \\
\text { notify the project initiator } \\
\text { if the package has been } \\
\text { rejected or returned. }\end{array}$ & 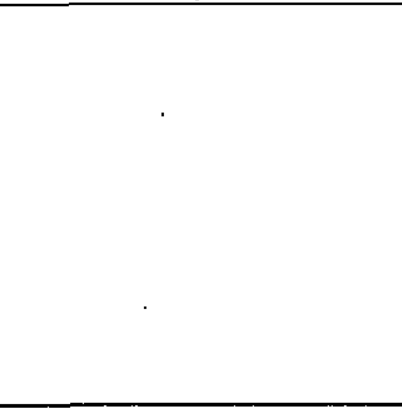 & \\
\hline $\begin{array}{l}\text { 38. Decisions/ } \\
\text { rationale recorded } \\
\text { and traced } \\
(1.1-2.6)\end{array}$ & $\begin{array}{l}\text { HANDI } 2000 \\
\text { While the HANDI } 2000 \text { Project } \\
\text { Management system does not } \\
\text { contain a specific data element } \\
\text { or panel for the entry of } \\
\text { decisions and rationale, the } \\
\text { module does allow entry of an } \\
\text { unlimited number of } \\
\text { Justification documents that are } \\
\text { controlled at the project level. } \\
\text { The planning of an unlimited } \\
\text { number of cost and schedule } \\
\text { plans also can reffect the } \\
\text { different scenarios represented } \\
\text { by various rationales } \\
\text { considered during the project } \\
\text { planning. One of the project } \\
\text { cost and schedule plans is } \\
\text { approved for execution of the } \\
\text { project. When the cost and } \\
\text { schedule plan is no longer } \\
\text { viable, another cost and } \\
\text { schedule plan may be } \\
\text { substituted. This requires a re- } \\
\text { approval of the project. }\end{array}$ & $\begin{array}{l}\text { HANDI } 2000 \\
\text { - Project definition data. } \\
\text { - Project justification. } \\
\text { - Project schedule data. } \\
\text { - Project budget data. } \\
\text { - Work order tasks. } \\
\text { - P3 working schedule. }\end{array}$ & $\begin{array}{l}\text { HANDI } 2000 \\
\text { AAA notification to } \\
\text { project manager based on } \\
\text { project set alarms as } \\
\text { related to percent of costs } \\
\text { and schedule. } \\
\text { - Automatic rollup to the } \\
\text { project from work } \\
\text { management of estimated } \\
\text { actual cost of labor, } \\
\text { contract labor, and } \\
\text { materials on work order } \\
\text { tasks associated to a } \\
\text { project. } \\
\text { - Linkage of contracts to } \\
\text { project activities and } \\
\text { automatic update of } \\
\text { project as to contract costs } \\
\text { to date. } \\
\text { Batch interface from the } \\
\text { HANDI } 2000 \text { Project } \\
\text { Management module to } \\
\text { Microsoft Project'M } \\
\text { scheduling tool. } \\
\text { - Ability to define and save } \\
\text { cost and schedule } \\
\text { scenarios for a project and } \\
\text { to proceed with the } \\
\text { selected plan. }\end{array}$ & $\begin{array}{l}\text { Basis for project or task } \\
\text { may be entered and will } \\
\text { then be retained for the } \\
\text { duration of the project. } \\
\text { When the documents and } \\
\text { ECC modules are } \\
\text { implemented, the complete } \\
\text { project background can be } \\
\text { placed in the task. }\end{array}$ & $\begin{array}{l}\text { HANDI } 2000 \text { does not support } \\
\text { comprehensive } \\
\text { decision/rationale information } \\
\text { recording and analysis. } \\
\text { PHMC plans to develop the } \\
\text { integrated solution to link } \\
\text { decisions recorded in HSTD to } \\
\text { resulting HANDI } 2000 \\
\text { projects, actions, and work } \\
\text { orders. See } \\
\text { Recommendation 7.6. }\end{array}$ \\
\hline
\end{tabular}


Table 5-1. Maturity Assessment/Information Capability and Functionality Matrix.

\begin{tabular}{|c|c|c|c|c|c|}
\hline (a) & (b) & (c) & (d) & (e) & (f) \\
\hline $\begin{array}{l}\text { Information Need / } \\
\text { Question Number }\end{array}$ & $\begin{array}{c}\text { General Description of System } \\
\text { Provisions }\end{array}$ & $\begin{array}{l}\text { PHMC HANDI } 2000 \text { System } \\
\text { Information } \\
\text { Capability }\end{array}$ & $\begin{array}{l}\text { PHMC HANDI } 2000 \text { System } \\
\text { Function } \\
\text { Capability }\end{array}$ & $\begin{array}{c}\text { User Comment on PHMC } \\
\text { HANDI } 2000 \text { Capability } \\
(*)=\text { intend to resolve with } \\
\text { Interim Stabilization Pilot } \\
\text { Project }\end{array}$ & $\begin{array}{c}\text { SE\&I Response } \\
\text { to } \\
\text { User Comment }\end{array}$ \\
\hline & & & $\begin{array}{l}\text { Project plans may be } \\
\text { submitted for approval } \\
\text { utilizing the standard } \\
\text { HANDI } 2000 \text { routing } \\
\text { features using AAA } \\
\text { messages to notify the } \\
\text { project initiator if the } \\
\text { package has been rejected } \\
\text { or returned. } \\
\text { - Supports the creation and } \\
\text { approval routing of an } \\
\text { authorization for } \\
\text { expenditure. }\end{array}$ & & \\
\hline $\begin{array}{l}\text { 39. Planning and } \\
\text { control metrics } \\
\text { monitored/used } \\
(1.2-1.3)\end{array}$ & $\begin{array}{l}\text { HANDI } 2000 \\
\text { HANDI } 2000 \text { Project } \\
\text { Management is designed to } \\
\text { provide project personnel with } \\
\text { the information necessary to } \\
\text { cffectively control projects } \\
\text { throughout the project life } \\
\text { cycle. Project Manngement is a } \\
\text { comprehensive on-line } \\
\text { information management } \\
\text { system supporting the } \\
\text { definition, planning, approving, } \\
\text { monitoring, and closing of } \\
\text { expense as well as capital } \\
\text { projects. The system } \\
\text { recognizes and supports the } \\
\text { requirement to maintain project } \\
\text { cost and work information in } \\
\text { one integrated system, } \\
\text { providing timely and useful } \\
\text { analysis and decision support } \\
\text { functionality. Project } \\
\text { Management is fully integrated } \\
\text { with other HANDI 2000 } \\
\text { systems including Action } \\
\text { Tracking, Inventory } \\
\text { Management, Accounts } \\
\text { Payable, Work Management, }\end{array}$ & $\begin{array}{l}\text { HANDI 2000 } \\
\text { - Project information. } \\
\text { - Project cost plans. } \\
\text { - Project schedulc plans. } \\
\text { - Project approval package. } \\
\text { - } \text { Authorization for } \\
\text { - expenditure. } \\
\text { - Project cost variance. } \\
\text { - Project work variance. } \\
\text { - Project available balance. } \\
\text { - Project commitments by } \\
\text { - Proediod. } \\
\text { - } \text { detail. } \\
\text { - Project forecast report. } \\
\text { - Project rollup report. } \\
\text { - Project manager tolerance } \\
\text { exception report. }\end{array}$ & $\begin{array}{l}\text { HANDI 2000 } \\
\text { - AAA notification to } \\
\text { project manager based on } \\
\text { project set alarms as } \\
\text { related to percent of costs } \\
\text { and schedule. } \\
\text { - Automatic rollup to the } \\
\text { project from Work } \\
\text { Management of estimated } \\
\text { actual cost of labor, } \\
\text { contract labor, and } \\
\text { materials on work order } \\
\text { tasks associated to a } \\
\text { project. } \\
\text { - Linkage of contracts to } \\
\text { project activities and } \\
\text { automatic update of } \\
\text { project as to contract costs } \\
\text { to date. } \\
\text { Batch interface from the } \\
\text { HANDI 2000 Project } \\
\text { Management module to } \\
\text { Microsoft Projectrm } \\
\text { scheduling tool. } \\
\text { - Ability to define and save } \\
\text { cost and schedule } \\
\text { scenarios for a project and }\end{array}$ & . & \\
\hline
\end{tabular}


RPP-4773, Rev. 0

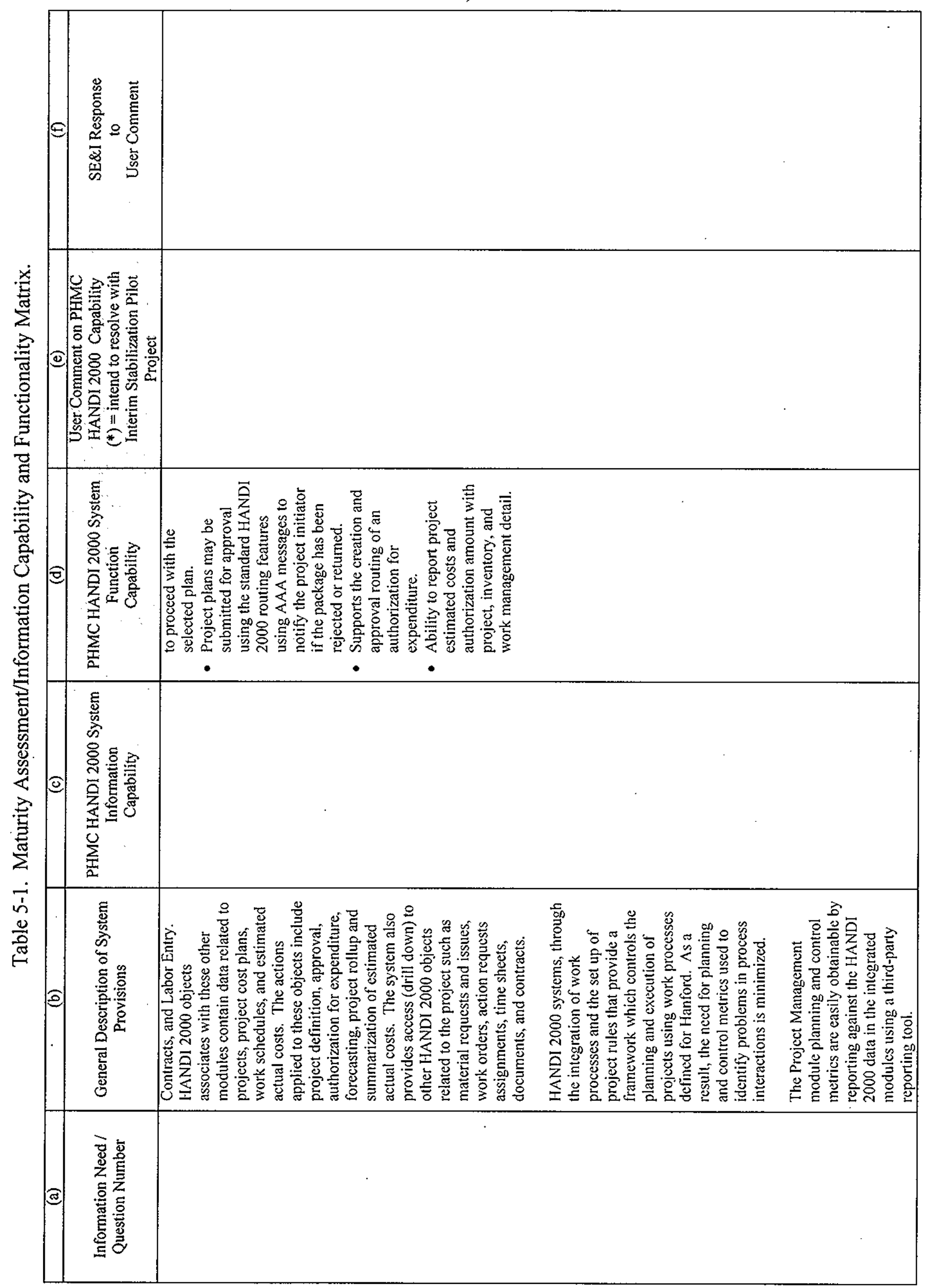


Table 5-1. Maturity Assessment/Information Capability and Functionality Matrix.

\begin{tabular}{|c|c|c|c|c|c|}
\hline (a) & (b) & (c) & (d) & (e) & (f) \\
\hline $\begin{array}{l}\text { Information Need/ } \\
\text { Question Number }\end{array}$ & $\begin{array}{c}\text { General Description of System } \\
\text { Provisions }\end{array}$ & $\begin{array}{l}\text { PHMC HANDI } 2000 \text { System } \\
\text { Information } \\
\text { Capability }\end{array}$ & $\begin{array}{l}\text { PHMC HANDI } 2000 \text { System } \\
\text { Function } \\
\text { Capability }\end{array}$ & $\begin{array}{l}\text { User Comment on PHMC } \\
\text { HANDI } 2000 \text { Capability } \\
\left({ }^{*}\right)=\text { intend to resolve with } \\
\text { Interim Stabilization Pilot } \\
\text { Project }\end{array}$ & $\begin{array}{l}\text { SE\&I Response } \\
\text { to } \\
\text { User Comment }\end{array}$ \\
\hline $\begin{array}{l}40 . \text { Inputs/outputs of } \\
\text { systems } \\
\text { engineering } \\
\text { process activities } \\
\text { clearly identified } \\
\text { (Project } \\
\text { Management Plan. } \\
\text { logic diagrams, } \\
\text { work plans, } \\
\text { Systems } \\
\text { Engineering } \\
\text { Management } \\
\text { Plan) }(2.1-3.3 \text {. }\end{array}$ & $\begin{array}{l}\text { HANDI } 2000 \\
\text { HANDI } 2000 \text { does not have } \\
\text { specific panels that define the } \\
\text { inputs and outputs of process } \\
\text { activities. There is, however, a } \\
\text { relationship between the } \\
\text { projects (project hierarchy). } \\
\text { There is also the ability to send } \\
\text { project summary task } \\
\text { information to a CPM software. } \\
\text { The CPM software can be used } \\
\text { to represent the project as a } \\
\text { Gantt chart or a Pert chart that } \\
\text { identifies inputs and outputs of } \\
\text { activities. } \\
\text { Work plans are defined in the } \\
\text { project information scope panel } \\
\text { and in individual work order } \\
\text { task package instructions. }\end{array}$ & $\begin{array}{l}\text { HANDI } 2000 \\
\text { - The ability to represent } \\
\text { the hierarchy of work at } \\
\text { Hanford is included in the } \\
\text { Project Management and } \\
\text { Work Management } \\
\text { modules. } \\
\text { - The project is made up of } \\
\text { a number of summary } \\
\text { tasks. The P3 schedule } \\
\text { defines the relationship of } \\
\text { the summary tasks. Work } \\
\text { Order task packages are } \\
\text { planned, executed, and } \\
\text { closed out in Work } \\
\text { Management while the } \\
\text { relationship between the } \\
\text { work order tasks is also } \\
\text { defined in the P3 } \\
\text { schedule. The integrated } \\
\text { schedule for RPP will } \\
\text { show the relationship } \\
\text { between the projects, the } \\
\text { summary tasks within the } \\
\text { projects, and the } \\
\text { individual work order task } \\
\text { relationship to the rest of } \\
\text { the work. }\end{array}$ & $\begin{array}{l}\text { HANDI 2000 } \\
\text { - Project Management } \\
\text { interface to critical path } \\
\text { management software } \\
\text { (Microsoft Project }{ }^{\mathrm{TM}} \text { ). } \\
\text { - Work Management } \\
\text { interface to critical path } \\
\text { management software } \\
\text { (Microsoft Project } \mathrm{T}^{\mathrm{M}}, \mathrm{P} 3 \text { ). } \\
\text { - Project hierarchy. } \\
\text { - Project information scope. } \\
\text { - Work order task } \\
\text { instructions/standards. }\end{array}$ & $\begin{array}{l}\text { The system does not create, } \\
\text { but retains information } \\
\text { provided to it. Both budget } \\
\text { and actual schedule and } \\
\text { costs are recorded and } \\
\text { retained for use. }\end{array}$ & $\begin{array}{l}\text { See Recommendation } 7.5 \text { for } \\
\text { mechanisms needed to ensure } \\
\text { a mature process, input } \\
\text { documentation, and output } \\
\text { documentation of the system } \\
\text { engineering process. }\end{array}$ \\
\hline
\end{tabular}


Table 5-1. Maturity Assessment/Information Capability and Functionality Matrix.

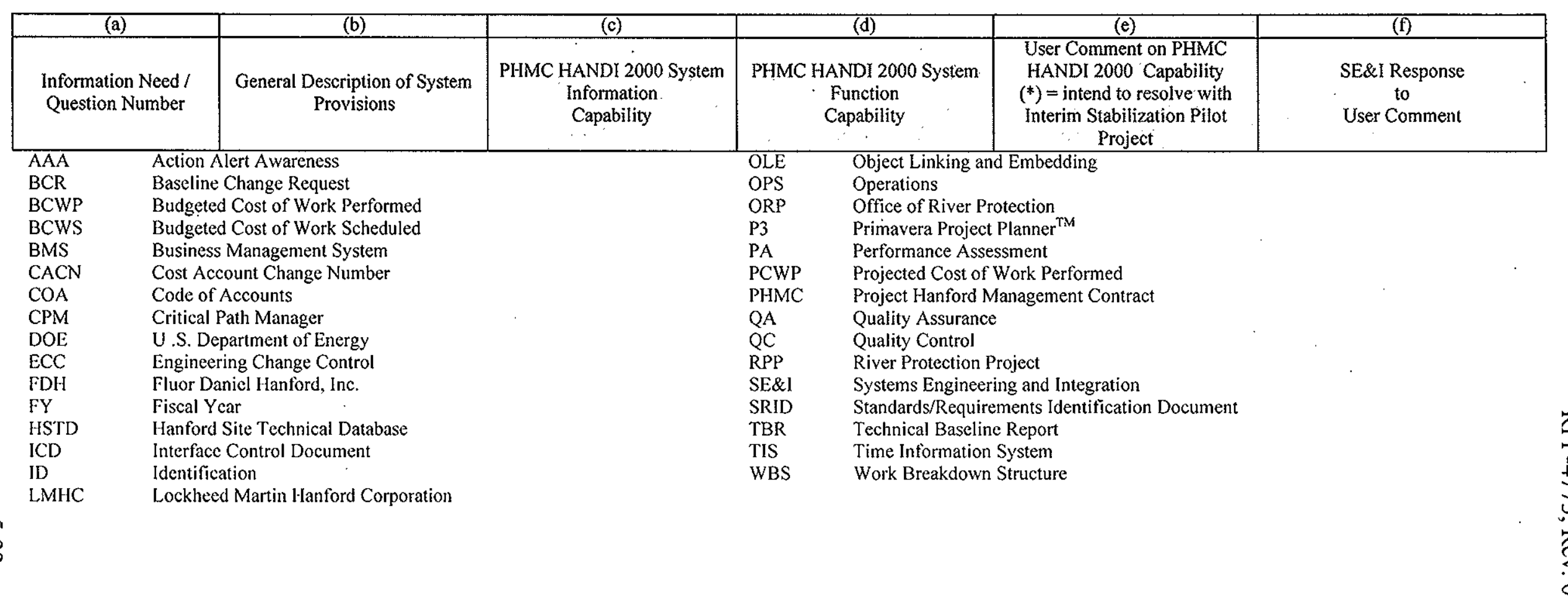


RPP-4773, Rev. 0

This page intentionally left blank. 


\subsection{GAP ANALYSIS}

This section provides the summary analysis of gaps identified between the HANDI 2000 information system and RPP project management needs. Gaps were based on analysis of Section 5.0, "Maturity Assessment/Information Capability and Functionality Matrix." Each gap relates to one or more information need listed in Section 5.0, Table 5-1.

The analysis identified gaps in six broad areas of project management needs: project scheduling, requirements management, information reporting and access, configuration management, process management, and risk management. The six gap analysis tables, Tables 6-1 through 6-6, list each information need where a gap surfaced. The "Related Information Needs" refers to the specific item in Table 5-1 on which the gap was based.

\subsection{PROJECT SCHEDULING GAP ANALYSIS}

Table 6-1. Information Needs Related to Project Scheduling Gap Analysis.

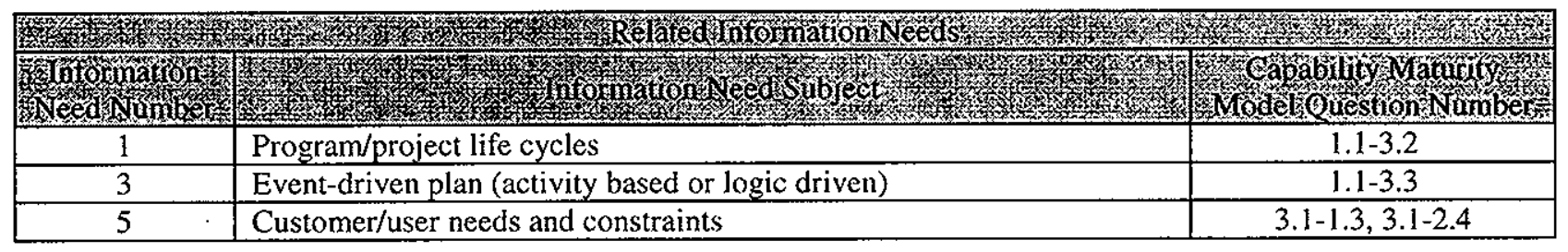

The HANDI 2000 Project Management component does not include an activity, resource, and cost scheduler. RPP, as well as the PHMC, currently uses P3 for scheduling projects. Projects could be scheduled with P3 and manually loaded and maintained in the HANDI 2000 system, but the change frequency immediately would drive costs well beyond the cost of developing an electronic interface solution. This cost becomes even more obvious because RPP requires the cost and resources to be segmented by fiscal month and year. Although P3 provides fiscal decomposition on reports, it does not store these fiscal results on its database negating the possibility of electronic transfer to HANDI 2000.

Milestones and completion dates may be part of the customer or user requirements. If the HANDI 2000 Project Management component is to house the RPP project baseline source data, then it must be able to feed P3 with baseline rates and target end dates. Again, volume and frequency precludes a manual entry approach to this issue. 


\section{Error}

An error occurred while processing this page. See the system log for more details. 


\section{Error}

An error occurred while processing this page. See the system log for more details. 


\section{Error}

An error occurred while processing this page. See the system log for more details. 
design and as-built drawings, the objects in the drawings, specifications, design documentation, performance criteria, verification criteria and results, bills of material, component interfaces, and, most importantly, the relationship between each of these. Furthermore, since these products represent scope and constraints to the project, they must be linked to the cost and schedule configurations managed through HANDI 2000.

Based on the FY 1999 Work Management project, LMHC has identified more than 16,000 facility components that must be managed in 6 of the 28 tank farms, 2 ancillary facility groups, and other managed mobile/portable equipment . To this number, add the configuration requirements for the remaining 12 tank farms, 2 ancillary facility groups and mobile/portable equipment (estimated to be 32,000 components or 48,000 total at completion), waste transfer systems, monitoring and control software systems, new systems being developed for waste feed delivery, and more than 1,000 operations and administrative procedures. The total number of configuration items will easily extend into the hundreds of thousands.

To assist in the configuration relationship development, as well as support ad hoc research on component information, the configuration management functionality should provide a "full text search" capability that examines drawings, documents, and database information in a single search.

Today's advanced configuration management systems support concurrent engineering through the information stored about interface designs, specifications, and documents. When a change to an interface is modified, the configuration management system must initiate comprehensive impact analysis and issue alerts to the appropriate cognizant engineers, technical authorities, and cost account managers. The current RPP environment relies on personnel knowledge and a highly stable workforce to accomplish these activities. When response time is critical, decisions to shorten the analysis and take risks may be necessary to accomplish a task within the time alloted.

In addition to HANDI 2000, configuration management is provided by the Records Information Management organization of Information Resources Management. This function is labor intensive, offers only search by keyword indexes built by clerical staff, and is limited to release control. Records Information Management manages documents, records, and drawings, but does not manage structures information such as requirements, performance and test criteria, test results, and technical data. The information is maintained in multiple databases but is accessible through paths external to the configuration management system. Therefore, modifications can be made and circulated while bypassing the management system. The process is slow and expensive and has resulted in duplicate functions being established by other Hanford contractors. 


\section{Error}

An error occurred while processing this page. See the system log for more details. 
resort to seeking other knowledgeable users, a time-consuming and expensive process, or ignore the procedure altogether. Procedures may overlap and conflict with other procedures. Nevertheless, employees are held accountable for proper conformance to procedures.

Also noted in the assessment was the lengthy and complex review, comment, and approval cycle for documents, noting that three to five weeks are typical to complete a cycle. In attempts to compensate for the configuration management weaknesses, the reviewer lists are extensive, seemingly well beyond that required for simple changes. This non-selective approach to reviews consumes an estimated average of one-hour per reviewer. As many as 1,200 procedure changes occur each year. Equally difficult, the procedure management team of 25 assembles comments from reviewers and redistributes to all the participants until consensus is reached. Comments from different reviewers may conflict in statements or philosophy. The assembly and redistribution to ensure that every reviewer sees every comment must be coordinated through the procedure management organization. The procedure is approved when each reviewer confirms that there are no further comments.

\subsection{RISK MANAGEMENT PROCESS GAP ANALYSIS}

Table 6-6. Information Needs Related to the Risk Management Process Gap Analysis.

\begin{tabular}{|c|c|c|}
\hline Mring & 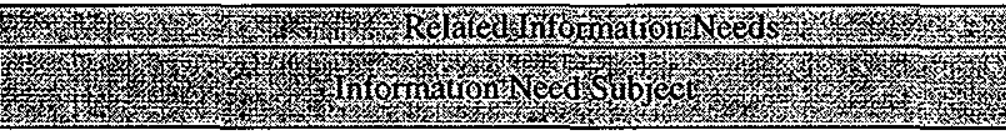 & 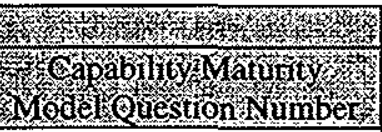 \\
\hline 21 & $\begin{array}{l}\text { Cost, resource, schedule, and technical risks-identification, analysis, } \\
\text { and mitigation }\end{array}$ & $1.1-3.4,1.2-3.2,1.7-1.1$ \\
\hline 23 & Risk thresholds & $1.7-3.3$ \\
\hline 24 & Risk Management List & $1.7-4.3$ \\
\hline 25 & Risks of different system concepts (alternatives) & $3.1-1.4$ \\
\hline 38 & Decisions/rationale recorded and traced & $1.1-2.6$ \\
\hline
\end{tabular}

Using a work order or action, the HANDI 2000 system can track risk-analysis and riskmitigation activities. However, the origination of the risk issue and the results of analysis and mitigation are not managed by HANDI 2000. Risk management activity tracking currently occurs external to the HANDI 2000 system. Larger risk activities may be added to the P3 schedule if planned in a TBR or added to the scope through a baseline change request. However, P3 does not provide access to information related to the risk with the activity making navigation between the activity, and the results are time consuming and difficult.

The HANDI 2000 system does not provide risk analysis and risk list management features. These capabilities require a risk management system. 
RPP-4773, Rev. 0

This page intentionally left blank. 
RPP-4773, Rev. 0

\subsection{RECOMMENDATIONS FOR GAP RESOLUTION}

This information systems assessment has identified six significant information system gaps where the HANDI 2000 system fails to support the comprehensive needs of project managers. The gaps are in the areas of project scheduling, requirements management, information reporting and access, configuration management, process management, and risk management. Section 6.0 describes the nature of each gap.

This section provides a recommendation as to how each gap might be mitigated. The solutions, based on accumulated knowledge of the product types described, require further feasibility analysis and detail design. LHMC Systems Engineering will submit an FY 2000 budget request to support the analysis and design activities.

The six recommendations tables, Tables 7-1 through 7-6, list each "Information Need Subject" where a gap surfaced. The "Information Need Number" refers to the specific item in Table 5-1 on which the gap was based.

\subsection{RECOMMENDATIONS FOR PROJECT SCHEDULING}

Table 7-1. Information Needs Related to Recommendations for Project Scheduling.

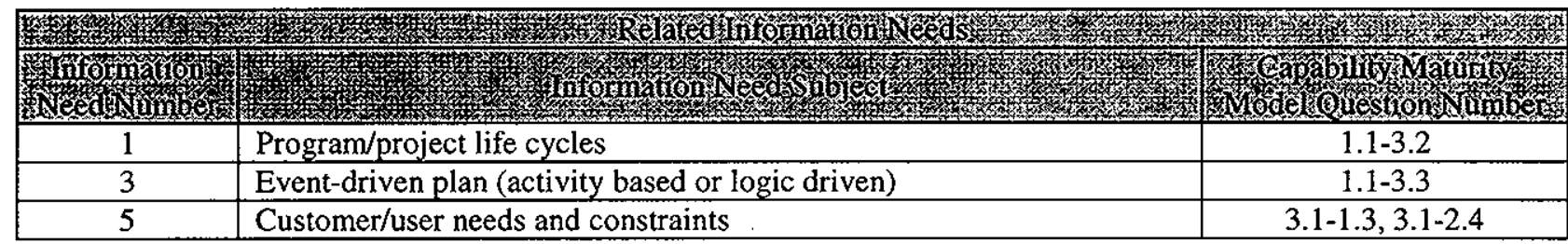

The project scheduling gap requires an interface between the project scheduler, currently P3, to the HANDI 2000 Project Management component. P3 can be used to allocate time and resources to project activities. HANDI 2000 can feed P3 the milestone dates, resource availability, and resource rates. Because $\mathrm{P} 3$ does not store fiscal month and year information, the interface must decompose the $\mathrm{P} 3$ output into fiscal months and years.

A software solution developed by the Tank Waste Remediation System in the mid-1990s performs this algorithm and loads a database similar to HANDI 2000. Brief analysis indicates that the software can be inexpensively modified to load the P3 information into the HANDI 2000 database. Figure 7-1 shows a feasible approach to solving the project scheduling and HANDI 2000 interface. 


\section{Error}

An error occurred while processing this page. See the system log for more details. 


\subsection{RECOMMENDATIONS FOR REQUIREMENTS MANAGEMENT}

Table 7-2. Information Needs Related to Recommendations for Requirements Management.

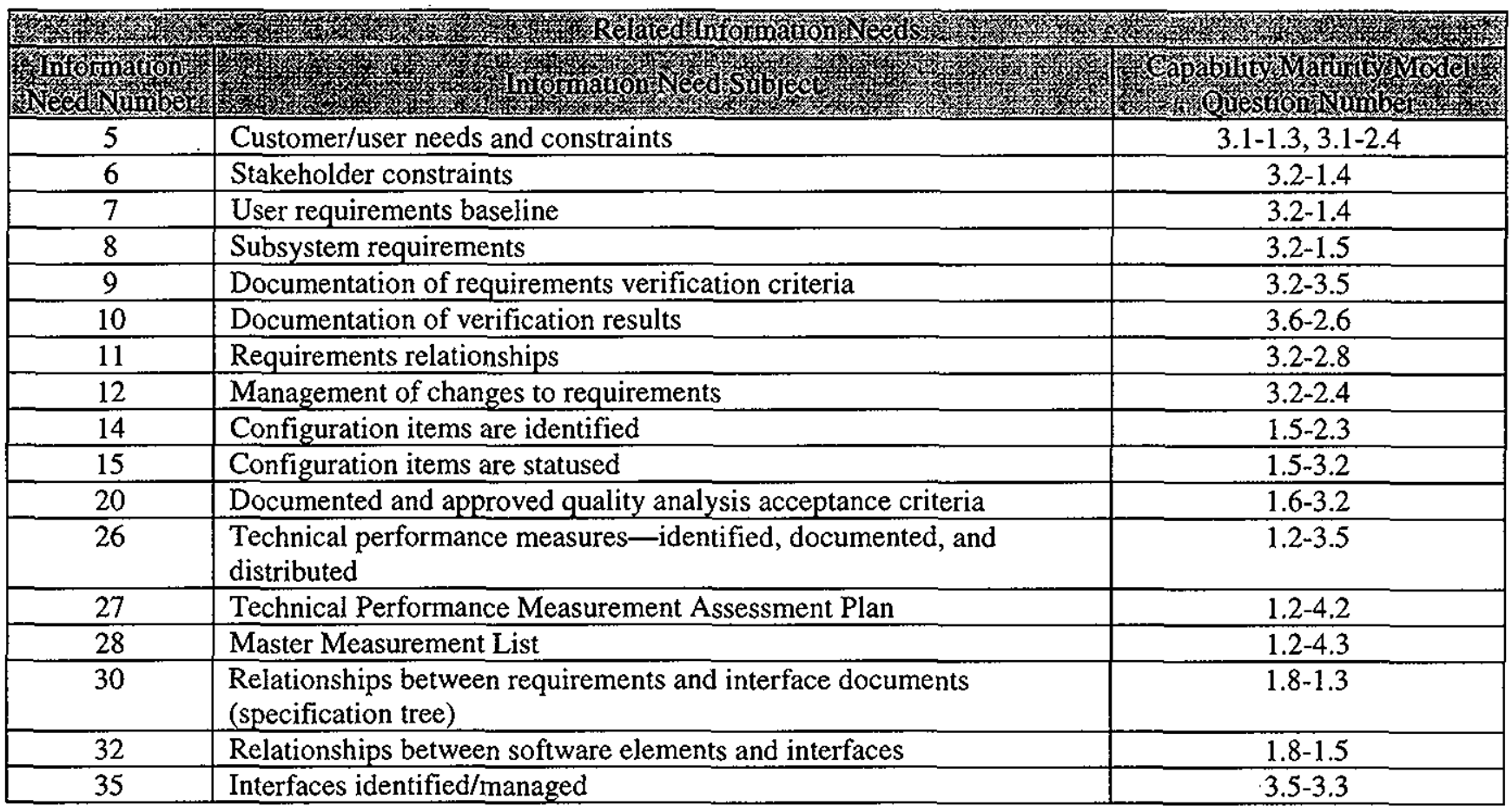

The requirements management gaps are summarized into three aspects: (1) some requirements types are not collected and stored in a consistently structured form; (2) the requirements are not configuration managed at a consistent detail level under a consistently applied process; and, (3) the requirements are not tied directly to the work performed to implement the requirements. The last item mostly addresses engineering costs to design and develop solutions compliant with requirements and constraints.

A feasible solution that LMHC has been examining during FY 1999 inputs all requirements and constraints to the HSTD system. On the surface, the approach seems overwhelming, but consider the following. All requirements are documented in some fashion and must be allocated to the designed solutions. This recommendation simply formalizes the requirements management process. Activities such as this appear overwhelming when legacy requirements are applied to the solution space. If the solution is applied to requirements of new allocation activities and those in early development stages, the volume impact is greatly reduced while improving the quality of present and future work. 
By placing the requirements, constraints, verification criteria, performance measures, and interface points in HSTD, configuration items can be identified and statused. The configuration management feature that LMHC has currently researched belongs to the Ascent Logic RDD.COM ${ }^{9}$ product, a significant upgrade to the RDD- $100^{\mathrm{TM}}$ product that currently manages the HSTD. Other requirements management products are currently under review at Hanford. If a new product becomes the site standard, it will need to have similar requirements configuration management capability. Strong configuration management enhances the quality of impact analysis, enables concurrent engineering, and provides instantaneous impact alerts to appropriate cognizant engineers, technical authorities, and cost account managers.

Part of the requirements configuration management solution involves linking the HSTD requirements to the work that implements the requirements, particularly the design, verification, development, and activation costs. A change in requirements can effect the cost, scope, and schedule for any one of these activities. Not only does this linkage provide for comprehensive requirements change impact analysis, but it also provides the complete drill-down capability desired in an information reporting and access system.

For direct linkage of HSTD requirements, a software interface module needs to be developed. LMHC believes that the software capability can be built to link requirements directly to work orders for requirements design and implementation. However, LMHC has not analyzed such an approach in detail.

A simpler approach, which creates an intermediate requirements product, uses the requirements management tool to generate requirements documents. HANDI 2000 easily attaches documents to projects, subprojects, actions, work orders, and work order tasks. Because the intermediate document creates an additional configuration item, associated administrative costs are likely. Figure 7-2 illustrates how this simpler approach would work.

${ }^{9}$ RDD.COM is a trademark of Ascent Logic Corporation, San Jose, California. 


\section{Error}

An error occurred while processing this page. See the system log for more details. 


\subsection{RECOMMENDATIONS FOR INFORMATION REPORTING AND ACCESS}

Table 7-3. Information Needs Related to Recommendations for Configuration Reporting and Access.

\begin{tabular}{|c|c|c|}
\hline 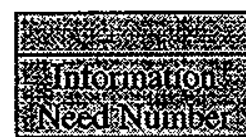 & 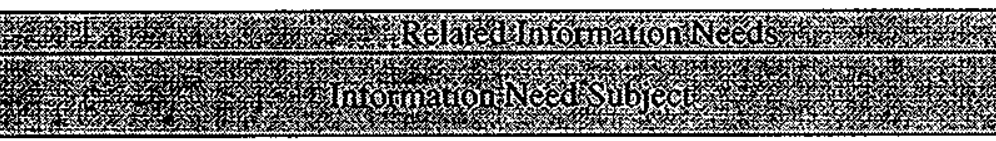 & 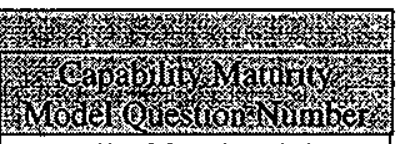 \\
\hline 13 & $\begin{array}{l}\text { Generic issue in design: Design review criteria should be available to } \\
\text { all involved }\end{array}$ & All of Section 3.3 \\
\hline 18 & Evaluations and assessments are available & All of Section 1.6 \\
\hline 19 & Quality Management activities are statused for conformance to plans & $1.6-2.7$ \\
\hline 22 & Visible to Project Manager & $1.7-1.3$ \\
\hline 26 & $\begin{array}{l}\text { Technical performance measures-identified, documented, and } \\
\text { distributed }\end{array}$ & $1.2-3.5$ \\
\hline
\end{tabular}

The information reporting and access gap calls for generally accessible information, using a simple user interface with strong information drill-down capability. LMHC recommends a data warehousing/report writer utility system to resolve this deficiency.

One COTS product that LMHC has examined superficially to meet the requirements is called BROADBASE ${ }^{10}$. This product has already been deployed at Los Alamos in conjunction with the Passport ${ }^{\mathrm{TM}}$ product, the major component of the HANDI 2000 system. The advantage of using BROADBASETM is that the vendor already has performed extensive analysis on management information needs and designed the warehouse information relationships to meet those needs. Experience suggests that 4,000 to 6,000 labor hours may be saved by acquiring this turn-key system for executive and general user information reporting and access.

Since BROADBASETM only addresses the Passport ${ }^{\mathrm{TM}}$ component of HANDI 2000 , a significant effort still will be required to address technical, engineering, safety, and operations information. The mechanism for handling non-standard database information such as used in HSTD and configuration management systems must be analyzed. Whether BROADBASETM is the selected solution or not, most data warehouse and report writer products, once set up, use an Intranet style interface and make standard and ad hoc reports simple to develop and access. Figure 7-3 shows a conceptual model of how the information reporting and access approach might work.

${ }^{10}$ BROADBASE is a trademark of Broadview Associates, LLC, Fort Lee, New Jersey. 
Figure 7-3. An Executive Reporting and Access Approach.

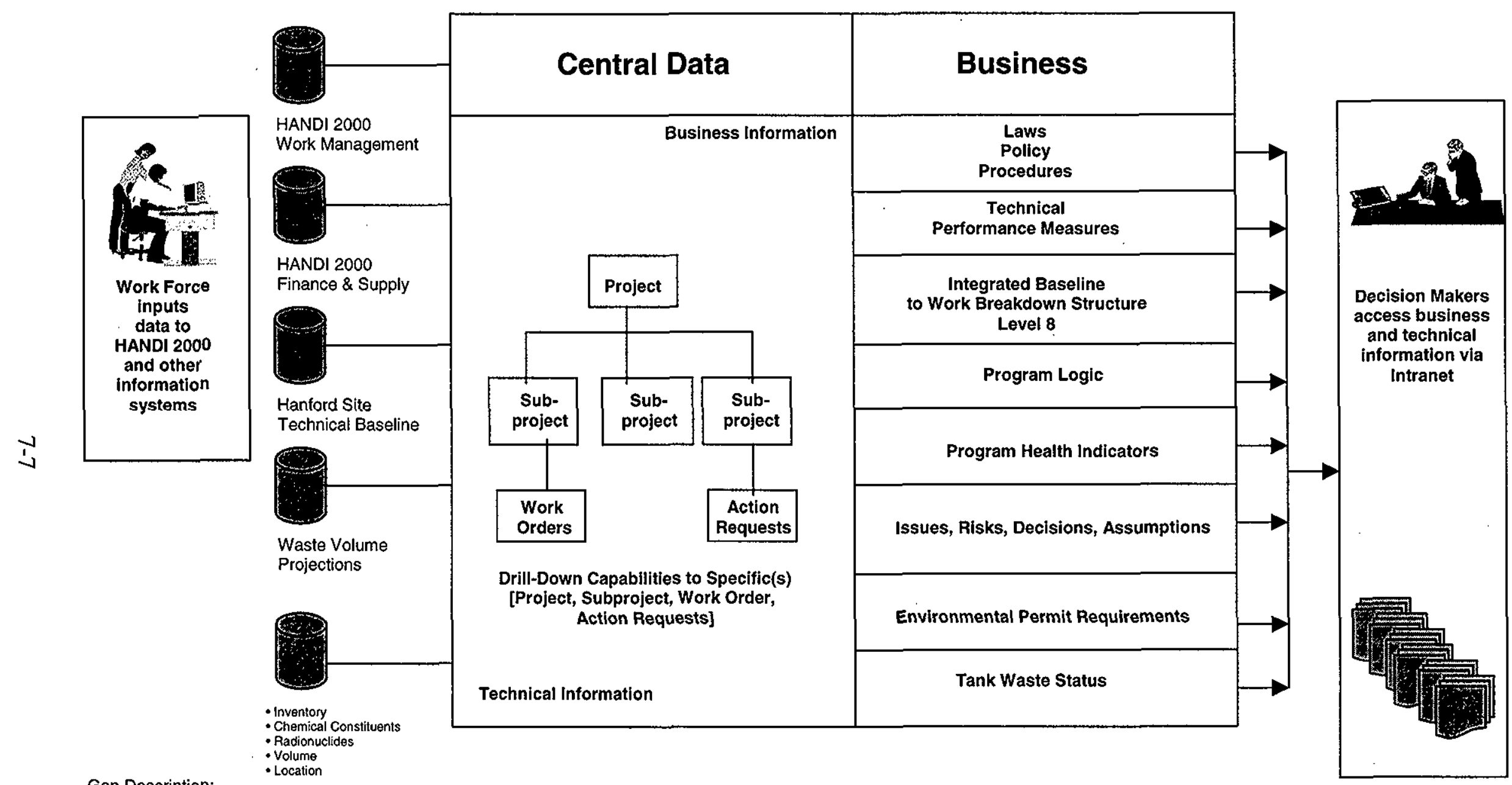

Gap Description

- Managers and the general user community need easy access to the requirements that determine what work they must do and how that work must be performed.

-Although the HANDI 2000 system stores administrative and field performance metrics, it does not provide an adequate reporting facility for any function.

Approach: The Broadbase Indus Knowledge Warehouse will provide, via the Intranet, managers and the general user community easy access to Business Views of Hanford data from many various sources. The architectural framework extracts data from the operational environment on a scheduled basis to the Central Data Warehouse and then combines, organizes, and loads these data into a separate environment that is optimized for decision support. Data are converted into information, thereby, enabling

managed drill-down capabilities of project specifics (e.g., requirements), on-line analysis, and business/executive reporting of administrative and field performance metrics. 


\subsection{RECOMMENDATIONS FOR CONFIGURATION MANAGEMENT}

Table 7-4. Information Needs Related to Recommendations for Configuration Management.

\begin{tabular}{|c|c|c|}
\hline 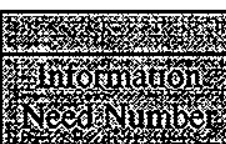 & 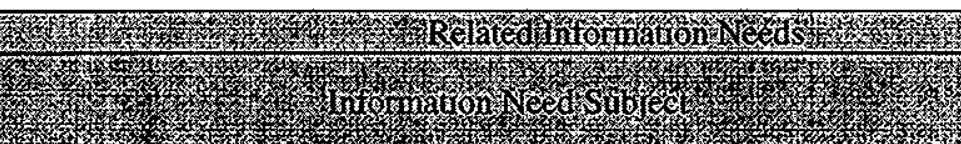 & 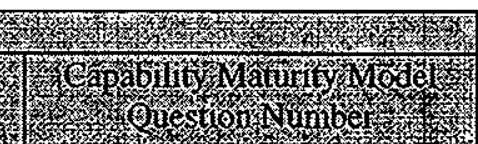 \\
\hline 4 & Logic diagrams (to depict predecessor-successor relationships) & $3.5-4.3$ \\
\hline 5 & Customer/user needs and constraints & $3.1-1.3,3.1-2.4$ \\
\hline 6 & Stakeholder constraints & $3.2-1.4$ \\
\hline 7 & User requirements baseline & $3.2-1.4$ \\
\hline 8 & Subsystem requirements & $3.2-1.5$ \\
\hline 9 & Documentation of requirements verification criteria & $3.2-3.5$ \\
\hline 10 & Documentation of verification results & $3.6-2.6$ \\
\hline 11 & Requirements relationships & $3.2-2.8$ \\
\hline 12 & Management of changes to requirements & 3.2-2.4 \\
\hline 14 & Configuration items are identified & $1.5-2.3$ \\
\hline 15 & Configuration items are statused & $1.5-3.2$ \\
\hline 20 & Documented and approved quality assurance acceptance criteria & $1.6-3.2$ \\
\hline 30 & $\begin{array}{l}\text { Relationships between requirements and interface documents } \\
\text { (specification tree) }\end{array}$ & $1.8-1.3$ \\
\hline 31 & $\begin{array}{l}\text { Relationships between drawings of physical elements of the system } \\
\text { (drawing tree) }\end{array}$ & $1.8-1.4$ \\
\hline 34 & $\begin{array}{l}\text { Concurrent engineering information is passed between the groups } \\
\text { involved in concurrent engineering }\end{array}$ & All of Section 1.4 \\
\hline 35 & Interfaces identified $/$ managed & $3.5-3.3$ \\
\hline 36 & Interface Control Documents & $3.5-4.2$ \\
\hline
\end{tabular}

Although HANDI 2000 provides an adequate cost and schedule configuration management capability, it falls far short of meeting the needs from a requirements, engineering, safety, and technical information aspect. Section 7.2 discussed the use of the requirements management product as a reasonable solution to the requirements configuration management gap.

The market offerings for COTS configuration management products for technical information, drawings, and documents are extensive. LMHC has been evaluating a specific product from Indus International, Inc. called Curator. Curator maintains an advantage over similar products because of its integration with the HANDI 2000 engineering change control and document management components. The Curator/HANDI 2000 products are loosely integrated in current product releases. However, LMHC expects the integration to increase substantially in subsequent releases. Indus International, Inc. may eventually combine their configuration management, document management, and engineering change components into a single component. 
Section 6.4 , the gap analysis on configuration management, pointed out that the configuration management needs include status and relationships of design and as-built drawings, the objects in the drawings, specifications, design documentation, performance criteria, verification criteria and results, bills of material, and component interfaces. Additionally, they must be linked to the cost and schedule configurations managed through HANDI 2000.

Among the most difficult issues in implementing comprehensive configuration management is conversion of legacy information. Still, that conversion only scratches the surface of the information integration effort required to yield full benefits. LMHC does not expect to launch a massive configuration data collection and integration effort on all legacy items. However, new configuration items, coupled with a prudent integration of high-activity legacy items, will yield efficient quality results immediately.

Much of the benefit will come from the concurrent engineering aspect that will enable the RPP privatization contractor to design infrastructure and processing interface components in full synchronization with the waste feed delivery design. The cognizant engineering features will selectively alert appropriate cognizant engineers, technical authorities, and cost account managers when a change could affect the path forward of an integrated element whether it be cost, schedule, technical design, procedure, or otherwise.

Additional benefits will accrue from the project management quality aspect associated with enhanced change impact analysis accuracy. General user's ability to access their information with minimal-to-no LMHC support will also increase overall RPP productivity and idea stimulation. LMHC views the configuration management system as a replacement for a large portion of the labor-intensive Records Information Management operation of the Information Resource Management function.

Figure 7-4 illustrates an approach to a configuration management system architecture. Analyses on the technical integration of the configuration management component have yet to be performed. LMHC Systems Engineering will submit an FY 2000 budget request for these analyses as described in TBR 710.042 . 


\section{Error}

An error occurred while processing this page. See the system log for more details. 


\section{Error}

An error occurred while processing this page. See the system log for more details. 
LMHC offers two approaches to formalizing processes depending on the nature and scope of the activity. For processes where costs must be collected (e.g., systems engineering projects), LMHC recommends the creation of HANDI 2000 projects and/or work orders with specific tasks and personnel assigned. HANDI 2000 projects allow multiple work orders representing major tasks or milestones. Work orders support standard task list templates with the attachment of required input and output document templates. Work order templates, or model work orders, provide a means to formalize large engineering and administrative tasks. Figure 7-5 shows the work order approach to formalizing processes with attached inputs and outputs. This approach uses standard HANDI 2000 work management facilities and provides traceability back to the RPP baseline and forward to the work results. Costs to execute the process are collected through the HANDI 2000 labor entry component.

For shorter, high-volume processes, processes that require varying skill sets for short periods of time and processes that do not need to collect costs, LMHC recommends a workflow management system. From an economics and integration standpoint, the Curator product may offer the best solution, especially if selected for configuration management also. Like HANDI 2000 work orders, workflow processes can be set up as templates, with predefined routings, and tuned to a specific execution situation. Workflow procedure steps attach and route documents or transactions to the specific individual that needs to take action. Procedures may be executed serially, in parallel, or a combination of both. When an action arrives at an individuals e-mail inbasket, the action is logged in for performance tracking. When the individual completes the action, a system creates a logout record.

From a concurrent engineering perspective, documents that require concurrent and iterative reviews can be handled without intermediate collection and redistribution. Each participant in a document review can add comments, or "mark up" the document. They can see the comments of other reviewers as the comments are developed. This includes engineering drawings as well as procedures and specifications. Reviewers can be added during the review and markup process. Delegated reviewers and actionees automatically are brought into a process when a primary resource becomes unavailable (e.g., out of the office).

The systems provides electronic approval. It automatically prompts for overdue actions and maintains execution status with respect to step and individuals. As an electronic system, other than maintenance of the processes themselves, control of the number or state of processes is insensitive to volumes. The processes themselves are configuration managed. Through hyperlink capability, the process maintains linkage to specific requirements statements within documents. The full text search capability applies to the description and data about processes as well as their related documents or transactions. These features aid in performing impact analysis and process simplification efforts.

Figure 7-6 illustrates the workflow process approach. LMHC Systems Engineering will submit an FY 2000 budget request for a process management system under TBR 710.042. 


\section{Error}

An error occurred while processing this page. See the system log for more details. 


\section{Error}

An error occurred while processing this page. See the system log for more details. 


\subsection{RECOMMENDATIONS FOR RISK MANAGEMENT}

Table 7-6. Information Needs Related to Recommendations for Risk Management.

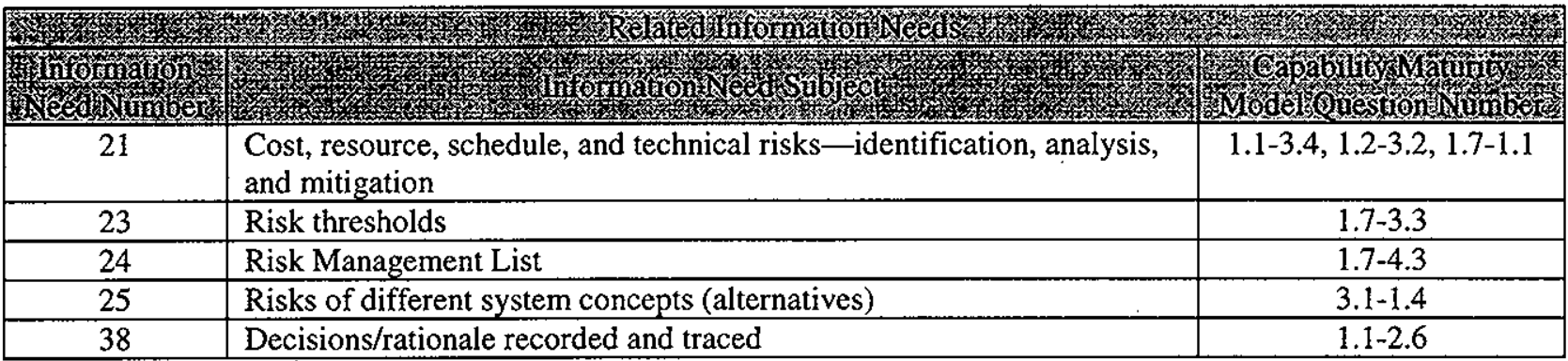

Using one of the process management approaches described in Section 7.5, HANDI 2000 can support the risk management process. As risk results are determined and decisions are made, the record of those decisions are attached to the process manager and maintained under configuration control through the configuration manager.

The actual analysis process requires a risk management system. LMHC Systems Engineering has been reviewing risk management tools. At this time no system selection decisions have been made. Budget to proceed with a risk management system procurement will be requested when the requirements and return on investment are better defined. Figure 7-7 shows how the risk management system can work with the HANDI 2000 system. This argument also applies to the Decisions, Enabling Assumptions, and Issues processes. 


\section{Error}

An error occurred while processing this page. See the system log for more details. 
RPP-4773, Rev. 0

APPENDIX A

NOTES OF AGREEMENTS REACHED ON CONTENTS OF INFORMATION SYSTEMS ASSESSMENT 
RPP-4773, Rev. 0

This page intentionally left blank. 


\section{APPENDIX A}

\section{Information Systems Assessment Notes on Agreements Reached February 24, 1999}

By: Hal Wacek

March 9, 1999

Attendees: Michael David, Gar Norman, Dan Francis, Hal Wacek

Item Reviewed: Preliminary draft outline of the planned report that would constitute the product to be delivered to satisfy the requirements of FY 99 Performance Agreement (PA) TWR 7.1.1.

Comments on plans and draft outline:

1. Have the Executive Summary summarize the document and its results for executives only. Agreed (AMD, 3/20/99)

2. The document is to be written for eventual distribution to the public.

Agreed (AMD, 3/20/99)

3. The planned Table of Contents would be acceptable once the changes noted below are made in it.

Agreed (AMD, 3/20/99)

4. The assessment will be made under the assumption that all information needed to answer the Performance Agreement assessment questions either is or will be available through the Hanford Intranet. Intranet accessibility is planned for accomplishment through Hanford Data Integrator (HANDI) modules; however, the source will be transparent to the user. If data are currently available in HANDI or some other Intranet-accessible data source, the answer to its availability will be "yes" even if that data source is not currently linked to the Intranet. Gaps in HANDI modules or other databases will be determined based on these criteria.

Agreed (AMD, 3/20/99).

5. It was accepted that no formal questioning or development of Program or Project Managers' needs would be made to determine their information needs. Only the Assessment Procedure's assessment questions would be asked of the River Protection Project information systems. This is what was agreed to. However, the Contractor at its discretion can obtain user input to any depth desired.

Agreed (AMD, 3/20/99). 
6. It was suggested that the information planned for Section 4.0 of the document be placed in some column of the matrix planned for Section 5.0, after the assessment question. In this way, both the assessment question and its answer showing the data type available (or a blank) would be immediately visible. This suggestion appeared desired by all.

Agreed (AMD, 3/20/99). The suggestion will be implemented if Lockheed Martin Hanford Corporation determines that the information topics listed in Section 4.0 have a one-to-one relationship with the questions from the Systems Engineering questionnaire. If the information topics have a one-to-many or many-to-many relationship, then Section 4.0 will eliminate unnecessary repetition in the Section 5.0 table.

7. It was requested that the current location or path for each data type be included in the data type column, so that program and project managers could use the report as a guide for obtaining answers to assessment questions. This request was taken under consideration. Agreed (AMD, 3/20/99).

8. The appendices will contain the details of the assessment for those interested. Agreed (AMD, 3/20/99).

This group agreed that another draft will be formed incorporating these items, and that that draft would be reviewed again before the assessment commenced.

Agreed (AMD, 3/20/99). 


\title{
RIVER PROTECTION PROJECT (RPP) INFORMATION SYSTEMS ASSESSMENT REPORT (SECTIONS 1.0 THROUGH 4.13) \\ Office of River Protection (ORP) Review Comment Disposition June 10, 1999
}

\author{
Meeting Attendees: \\ Hal Wacek, ORP \\ Skip Heinemeyer, FDH \\ Michael David, LMHC \\ Adria Johnson, LMSI
}

\begin{tabular}{|c|c|c|c|c|c|}
\hline Item & ORP Comment/Discrepancy & RPP Response & Accept & Reject & Comments \\
\hline 1 & $\begin{array}{l}\text { Dan J. Francis - Section 2.1, first } \\
\text { paragraph, last sentence: } \\
\text { "... guidance for assessing } \\
\text { discipline." It may be more } \\
\text { correct to say, "assessing the } \\
\text { organization's maturity in the } \\
\text { application of key focus areas." }\end{array}$ & RPP agrees to change wording as noted. & $\checkmark$ & & \\
\hline 2 & $\begin{array}{l}\text { Dan J. Francis - Section } 2.1 \text {, } \\
\text { second paragraph. This } \\
\text { paragraph discusses the genesis } \\
\text { of the questionnaire and the } \\
\text { various levels. There are } \\
\text { actually } 6 \text { levels, from } 0 \text { to } 5 \text {. } \\
\text { However there are no questions } \\
\text { for level } 0 \text {, the "initial" level. } \\
\text { See the INCOSE model } \\
\text { version } 1.5 \text { for a more detailed } \\
\text { discussion. Some of the material } \\
\text { present in Section } 2.1 \text {, second } \\
\text { paragraph is not entirely } \\
\text { accurate. }\end{array}$ & $\begin{array}{l}\text { RPP will rewrite this section to read: } \\
\text { " } 2.1 \text { Background } \\
\text { DOE Office of River Protection initiated } \\
\text { this information system assessment to } \\
\text { provide understanding of how } \\
\text { information systems implemented or } \\
\text { proposed by the PHMC assist project } \\
\text { managers in accomplishing their projects } \\
\text { in a disciplined fashion. The Systems } \\
\text { Engineering Maturity Assessment } \\
\text { Process - Assessment Questionnaire } \\
\text { (see Appendix C or Hanford Intranet } \\
\text { web site } \\
\text { Shttp://www.rl.gov:1050/twrs/syseng/se } \\
\text { proc.htm }>\text { ) established the guidance for } \\
\text { assessing maturity. } \\
\text { The questionnaire is based on the } \\
\text { International Council on Systems } \\
\text { Engineering (INCOSE), System } \\
\text { Engineering Capability Assessment } \\
\text { Model, version } 1.5 \text {. The model states } \\
\text { performance maturity in terms of } 6 \\
\text { levels, level } 0 \text { being the initial level and } \\
\text { level } 5 \text { being the highest quality } \\
\text { performance. The INCOSE model } \\
\text { includes questions pertaining to Levels } 1 \\
\text { through } 5 \text {. The questionnaire includes } \\
\text { questions from Levels } 1 \text { through } 3 \text {. If } \\
\text { answered favorably, the questionnaire } \\
\text { would consider a project to be } \\
\text { performing at maturity level } 3 \text {, a } \\
\text { performance level acceptable to the }\end{array}$ & $\sqrt{ }$ & & . \\
\hline
\end{tabular}


RPP-4773, Rev. 0

\begin{tabular}{|c|c|c|c|c|c|}
\hline Item & ORP Comment/Discrepancy & RPP Response & Accept & Reject & Comments \\
\hline & & $\begin{array}{l}\text { general business community. Higher } \\
\text { levels address incremental risk reduction } \\
\text { and performance optimization. } \\
\text { In order to perform the assessment, the } \\
\text { Department of Energy, Office of River } \\
\text { Protection at Richland, Washington, and } \\
\text { LMHC analyzed the questionnaire items } \\
\text { to develop a list of implicit information } \\
\text { requirements. Not all of the } \\
\text { questionnaire items implied information } \\
\text { requirements, and some implied multiple } \\
\text { information requirements. The analysis } \\
\text { resulted in the "information topics" } \\
\text { listed in Section } 2.3 \text {. } \\
\text { The value of the assessment report is } \\
\text { grounded in the recommendations } \\
\text { (Section } 7.0 \text { ) regarding gaps, (i.e., } \\
\text { weaknesses and voids, in information } \\
\text { essential to successful project } \\
\text { performance). The recommendations } \\
\text { are intended to influence the priority of } \\
\text { RPP information system projects for the } \\
\text { future." }\end{array}$ & & & 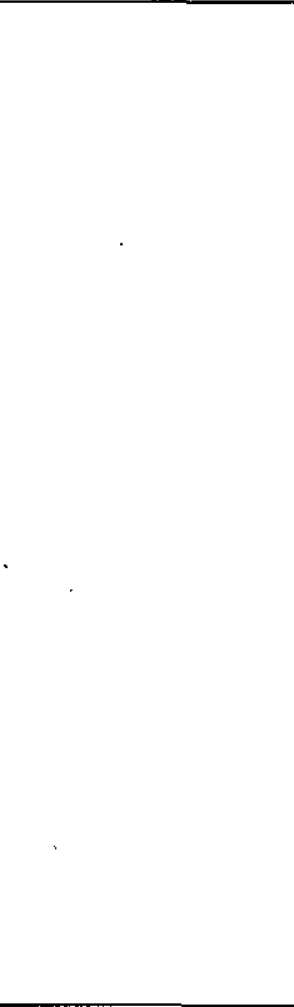 \\
\hline 3 & $\begin{array}{l}\text { Dan J. Francis - Section } 2.3 \text {. } \\
\text { The paragraph refers to } \\
\text { subsequent "sections" that may } \\
\text { be more appropriately referred to } \\
\text { as "tables" (2.3.A and 2.3.B) } \\
\text { and/or "figures" (2.3.C). }\end{array}$ & RPP agrees to change wording as noted. & $\checkmark$ & & \\
\hline 4 & $\begin{array}{l}\text { Dan J. Francis - Section } 4.10 . \text { It } \\
\text { is not clear why this section has } \\
\text { a slightly different format than } \\
\text { the other sections (i.e. "Key } \\
\text { Question"). }\end{array}$ & $\begin{array}{l}\text { RPP agrees to change wording. The } \\
\text { format will be changed to, "Concurrent } \\
\text { engineering information is passed } \\
\text { between the groups involved in } \\
\text { concurrent engineering." }\end{array}$ & $\begin{array}{c}\checkmark \\
\text { with } \\
\text { comment }\end{array}$ & & $\begin{array}{l}\text { The format of this } \\
\text { bullet was } \\
\text { originally agreed to } \\
\text { during an initial } \\
\text { review of the report } \\
\text { outline. RPP } \\
\text { agrees to change } \\
\text { the format as } \\
\text { noted. }\end{array}$ \\
\hline 5 & $\begin{array}{l}\text { Dan J. Francis - Section 4.11, It } \\
\text { is not clear which Systems } \\
\text { Engineering processes will be } \\
\text { used as the standard. (Note: I } \\
\text { would only expect the "big } \\
\text { picture" view -- LMHC Systems } \\
\text { Engineering processes (or FDH } \\
\text { Systems Engineering process) } \\
\text { versus "other" organizations } \\
\text { systems engineering process. } \\
\text { What is the standard and what is } \\
\text { being measured?) }\end{array}$ & $\begin{array}{l}\text { RPP will opt to delete this section. } \\
\text { (Same as item 15.) }\end{array}$ & $\underset{\substack{\text { with } \\
\text { comment }}}{\checkmark}$ & & $\begin{array}{l}\text { During an initial } \\
\text { review of the report } \\
\text { outline, this } \\
\text { information need } \\
\text { was questioncd and } \\
\text { was marked with a } \\
\text { "?" to note that this } \\
\text { section may be } \\
\text { removed. }\end{array}$ \\
\hline
\end{tabular}


RPP-4773, Rev. 0

\begin{tabular}{|c|c|c|c|c|c|}
\hline Item & ORP Comment/Discrepancy & RPP Response & Accept & Reject & Comments \\
\hline 6 & $\begin{array}{l}\text { Hal J. Wacek - Section } 1.0 \text {, } \\
\text { paragraph } 2 \text {, second sentence. } \\
\text { What word(s) is missing in this } \\
\text { sentence? }\end{array}$ & $\begin{array}{l}\text { Sentence will be changed to read, "The } \\
\text { systems implementation is being } \\
\text { performed under the PHMC HANDI } \\
2000 \text { information system project." }\end{array}$ & $\checkmark$ & & \\
\hline 7 & $\begin{array}{l}\text { Hal J. Wacek - This draft report } \\
\text { implies in various sections (e.g., } \\
\text { Section 3.0) that what was } \\
\text { previously reported as the Work } \\
\text { Management System is now part } \\
\text { of the PHMC Business } \\
\text { Management System. Please } \\
\text { make all references to the } \\
\text { Business and Work Management } \\
\text { Systems consistent within this } \\
\text { report (e.g., Section 2.3.C). The } \\
\text { confusion becomes greater as } \\
\text { one progresses through the } \\
\text { report. }\end{array}$ & $\begin{array}{l}\text { An additional paragraph will be added to } \\
\text { section } 1.0 \text { "Purpose" of the report to } \\
\text { clarify this separation. The paragraph } \\
\text { will explain the system known as } \\
\text { HANDI } 2000 \text {. HANDI } 2000 \text { was } \\
\text { comprised of two phases; } 1 \text {. Business } \\
\text { Management System modules, and } 2 \text {. } \\
\text { Work Management System modules. } \\
\text { Phase } 1 \text { was implemented during } \\
\text { FY1998. To avoid any confusion, } \\
\text { HANDI } 2000 \text { will be used to refer to the } \\
\text { cntirc system, which includes BMS and } \\
\text { WMS. BMS and WMS, when used } \\
\text { within this report will refer to only the } \\
\text { modules originally associated with them. } \\
\text { A graphical depiction of the system is } \\
\text { located in section 2.3.C. }\end{array}$ & $\sqrt{ }$ & & \\
\hline 8 & $\begin{array}{l}\text { Hal J. Wacek - Section 2.3.B. } \\
\text { Please define "Implemented" in } \\
\text { a footnote to this table. Does it } \\
\text { mean all planned aspects of the } \\
\text { module are being used by } \\
\text { everyone involved, or some } \\
\text { lesser implementation level? As } \\
\text { an example, I understand the } \\
\text { Deficiency Tracking System is } \\
\text { less than user-friendly, and } \\
\text { requires specialists in that } \\
\text { database to operate it. }\end{array}$ & $\begin{array}{l}\text { If a module is identified as } \\
\text { "Implemented," it implies that the } \\
\text { module is fully operational across the } \\
\text { PHMC as planned by the HNF-1743, } \\
\text { FYI998 HANDI } 2000 \text { Project Execution } \\
\text { Plan, and implemented through } \\
\text { associated procedures. This means } \\
\text { working as agreed. }\end{array}$ & $\sqrt{ }$ & & \\
\hline 9 & $\begin{array}{l}\text { Hal J. Wacek - Section } 3.0, \\
\text { paragraph } 2 \text {, first sentence. } \\
\text { Should the words, "... as } \\
\text { constrained by contractual and } \\
\text { regulatory obligations." Be } \\
\text { deleted in this sentence? The } \\
\text { sentence is confusing otherwise. }\end{array}$ & RPP agrees to delete words as noted. & $\checkmark$ & & \\
\hline 10 & $\begin{array}{l}\text { Hal J. Wacek - Section } 4.2 \text {, } \\
\text { bullet } 2 \text {, second sentence. Does } \\
\text { the WBS actually display the } \\
\text { product(s) to be developed? It } \\
\text { only defines them at a high level, } \\
\text { as I understand it, in the WBS } \\
\text { data dictionary, not the WBS } \\
\text { itself. }\end{array}$ & $\begin{array}{l}\text { The noted definition will be changed to } \\
\text { "A product-oriented family trec } \\
\text { composed of work elements which result } \\
\text { from systems engineering efforts and } \\
\text { which completcly detines the program. } \\
\text { Defines the product(s) to be developed } \\
\text { or produced, and relates the elements of } \\
\text { work to be accomplished to each other } \\
\text { and to the end product. The WBS is } \\
\text { structured in accordance with the way in } \\
\text { which the work will be performed, and } \\
\text { reflects the way in which costs will be } \\
\text { summarized and eventually reported." }\end{array}$ & $\sqrt{ }$ & & \\
\hline
\end{tabular}




\begin{tabular}{|c|c|c|c|c|c|}
\hline Item & ORP Comment/Discrepancy & RPP Response & Accept & Reject & Comments \\
\hline 11 & $\begin{array}{l}\text { Hal J. Wacek - Section } 4.6 \text {, } \\
\text { paragraph 1. Please add the } \\
\text { words "timely and effective" as } \\
\text { follows: "Quality Management } \\
\text { provides for timely and effective } \\
\text { independent evaluation and } \\
\text { assessment ...". }\end{array}$ & $\begin{array}{l}\text { RPP agrees to change sentenced as } \\
\text { noted. }\end{array}$ & $\sqrt{ }$ & & \\
\hline 12 & $\begin{array}{l}\text { Hal J. Wacek - Section } 4.7 \text {, } \\
\text { bullets } 5 \text { and } 6 \text {. Please describe } \\
\text { the differences between these } \\
\text { two data items. Are tradeoffs } \\
\text { done on details of alternate } \\
\text { systems? }\end{array}$ & $\begin{array}{l}\text { Bullet } 6 \text { "Risks considered in tradeoff } \\
\text { studies" will be deleted. }\end{array}$ & $\sqrt{ }$ & & \\
\hline 13 & $\begin{array}{l}\text { Hal J. Wacek - Section } 4.9 \text {, } \\
\text { bullets } 1 \text { and } 5 . \text { What are the } \\
\text { differences between these two } \\
\text { data items? Please describe } \\
\text { them in the text of Section } 4.9 \text {. }\end{array}$ & $\begin{array}{l}\text { The definition following bullet } 1 \\
\text { "Archiving/retrieving project data" will } \\
\text { be moved up to define project data itself. } \\
\text { Bullets } 1 \text { and } 5 \text { will have the following } \\
\text { revised definitions; } \\
\text { - Archiving/retrieving project data. } \\
\text { There is a means to archive and } \\
\text { retrieve project data. } \\
\text { - Status of project data (at any given } \\
\text { time). Users have the ability to } \\
\text { obtain current pedigree of project } \\
\text { data under data management. }\end{array}$ & $\sqrt{ }$ & & \\
\hline 14 & $\begin{array}{l}\text { Hal J. Wacek - Section } 4.10, \\
\text { Key Question. A question } \\
\text { asking whether groups are } \\
\text { assigned to perform concurrent } \\
\text { engineering activities on the } \\
\text { project or program would also be } \\
\text { key. Is this question included in } \\
\text { the assessment? If so, add that } \\
\text { in this description. Why is this } \\
\text { Section in a different format than } \\
\text { the other parts of Section } 4.0 ?\end{array}$ & $\begin{array}{l}\text { This report is addressing the capabilities } \\
\text { of the system, not the people involved. } \\
\text { The information topic descriptions } \\
\text { should address how the system will } \\
\text { facilitate Concurrent Engineering across } \\
\text { the programs and projects. } \\
\text { Wording of this section will be changed } \\
\text { as described in item number } 4 \text { (above). }\end{array}$ & $\checkmark$ & & \\
\hline 15 & $\begin{array}{l}\text { Hal J. Wacek-Section } 4.11 \text {. } \\
\text { Why is the assessment in this } \\
\text { section being made? What gains } \\
\text { are expected from it? What } \\
\text { standard(s) of comparison will } \\
\text { be used? This section may cause } \\
\text { more problems for the report } \\
\text { than it solves! }\end{array}$ & $\begin{array}{l}\text { RPP will opt to delete this section. } \\
\text { (Same as item 5.) }\end{array}$ & $\checkmark$ & & \\
\hline 16 & $\begin{array}{l}\text { Hal J. Wacek - Section } 4.12 \text {, } \\
\text { bullet } 1 \text {, second sentence. Please } \\
\text { add the word, "management," in } \\
\text { this sentence as follows: "A } \\
\text { collection of management, } \\
\text { software, and hardware systems. } \\
\text {.". }\end{array}$ & $\begin{array}{l}\text { RPP agrees that in a generic sense that } \\
\text { "management" could be added. For the } \\
\text { purpose of this report because it deals } \\
\text { with information systems, we opt to } \\
\text { keep the wording unchanged. }\end{array}$ & $\sqrt{ }$ & & $\begin{array}{l}\text { This is now } \\
\text { Section } 4.11 \text {. }\end{array}$ \\
\hline
\end{tabular}




\begin{tabular}{|c|l|l|c|c|}
\hline Item & ORP Comment/Discrepancy & \multicolumn{1}{|c|}{ RPP Response } & Accept & Reject \\
\hline 17 & $\begin{array}{l}\text { Hal J. Wacek - Section 4.13, } \\
\text { bullet 2. Please include planning } \\
\text { for decisions in this assessment, } \\
\text { also. }\end{array}$ & $\begin{array}{l}\text { RPP opts to keep wording unchanged. } \\
\text { Planning for decision making is inherent } \\
\text { in directions contained in SEMP, } \\
\text { described in bullet 1. }\end{array}$ & $\checkmark$ & $\begin{array}{l}\text { This is now } \\
\text { Section 4.12. }\end{array}$ \\
\hline 18 & $\begin{array}{l}\text { Hal J. Wacek - Please respond to } \\
\text { Dan's five comments. }\end{array}$ & $\begin{array}{l}\text { Item numbers 1 through 5 of this } \\
\text { document refer to Dan's comments. }\end{array}$ & $\checkmark$ & \\
\hline
\end{tabular}


RPP-4773, Rev. 0

This page intentionally left blank. 
RPP-4773, Rev. 0

\section{APPENDIX B}

\section{PERFORMANCE AGREEMENT 7.1.1}

B-i 
RPP-4773, Rev. 0

This page intentionally left blank.

B-ii 
RPP-4773, Rev. 0

APPENDIX B

PERFORMANCE AGREEMENT 7.1.1

DE-AC06-96RL13200

Modification M057

\section{FY 1999 PERFORMANCE AGREEMENT (PA): TWR 7.1.1}

\section{SECTION 1}

General Information

Performance Expectation Number:

Performance Expectation Short Title:

Revision Number:

Responsible RL Organization:

RL Point of Contact:

Project Baseline Summary Number:

PA Incentive Fee:

Incentive Fee Distribution:

$0.0 \%$ at Objective Level

$0.0 \%$ at Measure Level

$0.6 \%$ at Expectation Level
TWR 7.1.1

Systems Engineering

Rev. 0, October 1, 1998

TWR/MSD

J. C. Peschong

RL-TW-10

0.6 percent of the total available FY 1999 incentive fee pool

SECTION 2

Performance Objective and Performance Measure

TWR 7 Performance Objective: Manage and Integrate Tank Waste Remediation System Activities.

TWR 7.1 Performance Measure: Provide necessary crosscutting technical management and integration products.

SECTION 3

Performance Expectation

TWR 7.1.1 Performance Expectation:

1) Issue a Contractor-approved life cycle TwRS Testing and Evaluation Management Plan (TEMP) by August 15, 1999.

2) Provide an assessment report on the selected Integrated Information System by July 31, 1999.

55 percent of the incentive fee for this PA may be earned by the Contractor for meeting the Item 1 of the Performance Expectation.

45 percent of the incentive fee for this PA may be earned by the Contractor for meeting the Item 2 of the Performance Expectation.

\section{SECTION 4}

Bonus: Positive/Negative (if applicable)

Increased Performance: N/A

Negative Incentive Fee: N/A 
FY 1999 PERFORMANCE AGREEMENT (PA): TWR 7.1.1

\section{SECTION 5}

Completion Criteria and Specifications

\section{General Requirements:}

In order to earn incentive fee under this PA, the Contractor shall: 1) meet the specific completion criteria and expectations set forth in this PA; and 2) not incur any unfavorable cost variance [(BCWP-ACWP)/BCWP] greater than 5.0 percent or incur any unfavorable schedule variance $[(B C W P-B C W S) / B C W S]$ greater than 7.5 percent, measured at the combined Project Baseline Summary level identified in Section 1, at the end of FY 1999.

\section{Performance Expectation Level:}

Approval of the products will be granted when the following conditions are met:

1. By February 15,1999 , the Contractor formally delivers to RL TWRS a Contractor-approved life cycle TWRS Testing and Evaluation Management Plan (TEMP) for review and comment via the RCR process. The TEMP shall:

- Establish the overall test and evaluation process for TWRS.

- Direct TWRS activities to generate activity-specific Test and Evaluation Plans and Technical Performance Measures in a graded manner.

- Ensure that test and evaluation planning processes and deliverables are integrated into the project baselines.

The Contractor is to revise the TEMP as needed to obtain RL TWRS SE approval of it by August 15, 1999, as described in Note 1. (55 percent)

2. By July 31, 1999, the Contractor delivers to RL TWRS an assessment report formed as follows:

- The Contractor selects and defines a TWRS Integrated Information System.

- The Contractor assesses the ability of that Information System to provide information through level 3 of the systems engineering maturity model for the TWRS Program, as defined by the current TWRS System Engineering Maturity Assessment procedure in HNF-IP-0842.

- The Contractor delivers a report describing the Information System, the assessment methods and results, and identifying gaps requiring resolution.

Increased Performance Level: N/A

\section{Negative Performance Level: N/A}

\section{Notes:}

1) RL TWRS SE shall be given thirty calendar days after formal delivery to review and comment on each delivery of the TEMP. If RL TWRS SE does not supply written response to any formal delivery of the TEMP within thirty calendar days, then the Contractor may assume that RL TWRS SE has formally accepted the document. 
RPP-4773, Rev. 0

\begin{tabular}{|c|c|}
\hline \multicolumn{2}{|c|}{ FY 1999 PERFORMANCE AGREEMENT (PA): TWR 7.1.1 } \\
\hline \multicolumn{2}{|c|}{ SIGNATURES } \\
\hline Contractor Project Manager & Date \\
\hline Contractor Contract Representative & Date \\
\hline RL Contracting Officer's Representative (COR) & Date \\
\hline RL Assistant Manager/Direct Report & Date \\
\hline RL Contracting Officer & Date \\
\hline
\end{tabular}


RPP-4773, Rev. 0

This page intentionally left blank. 
RPP-4773, Rev. 0

APPENDIX C

\section{INFORMATION SYSTEM ASSESSMENT PROCESS}

C-i 
RPP-4773, Rev. 0

This page intentionally left blank.

C-ii 
RPP-4773, Rev. 0

\section{APPENDIX C}

\section{INFORMATION SYSTEM ASSESSMENT PROCESS}

This report was created in response to Performance Agreement 7.1.1, Item 2, "Provide an assessment report on the selected Integrated Information System by July 31, 1999."

The information system assessment project began with the creation of a draft outline for the Information System Assessment Report by Lockheed Martin Hanford Corporation (LMHC). LMHC and the U.S. Department of Energy, Office of River Protection (DOE-ORP) reviewed the outline. LMHC revised the outline according to agreements reached during the review session. Appendix A contains notes from the review.

A project orientation kick-off meeting was held with the identified project team and management. The team consisted of players from LMHC; Indus International., Inc.; Lockheed Martin Services, Incorporated; and Fluor Daniel Hanford, Inc. (FDH). During the meeting the draft outline and project schedule were distributed. An overview presentation was given to the group to familiarize them with the intent of the project.

After the first four sections were completed, another review was held with LMHC and DOE-ORP. The document was revised according to agreements reached during the review. Refer to Appendix A for notes from the review.

Section 5.0, Table 5-1, "Maturity Assessment/Information Capability and Functionality Matrix," was the tool used for recording the assessment information. Columns $A$ lists the information needs. Column B provides general system provisions of current and available, but not implemented, system qualities. Columns $C$ and $D$ describe the system information and function capabilities. Column E provides all user comments collected during reviews and interviews with LMHC project managers. The project managers commented on the system information provided in the first four columns and the current ways of doing business at Hanford. Comments received were not screened during the process. Finally, Column F displays the System Engineering and Integration organization responses to the user comments. Several periodic reviews were held during the creation of the matrix to supply clarification and corrections if needed.

The "Maturity Assessment/Information Capability and Functionality Matrix" was analyzed by the System Engineering and Integration organization to identify gaps between the information needs of project managers and the current system capabilities. Identified gaps in six functional areas are listed in Section 6.0.

Recommendations for closure of identified gaps are described in Section 7.0 of the report. These recommendations will be used in future planning activities. 
RPP-4773, Rev. 0

Background information in support of the document is included in the following appendices:

- Appendix A, "Notes of Agreements Reached on Contents of Information Systems Assessment"

- Appendix B, "Performance Agreement 7.1.1"

- Appendix C, "Information System Assessment Process"

- Appendix D, "Systems Engineering Maturity Assessment Process - Assessment Questionnaire"

- Appendix E, "Project Hanford Management Project HANDI 2000 Module Descriptions"

- Appendix F, “Acronyms"

- Appendix G, "References and Bibliography"

- Appendix H, "Information Systems Assessment Project Participants." 
FAN-4773, Rev. 0

\section{APPENDIX D}

\section{SYSTEM ENGINEERING MATURITY ASSESSMENT PROCESS- ASSESSMENT QUESTIONNAIRE}


-4773, Rev. 0

This page intentionally left blank.

D-ii 
-4773, Rev. 0

\section{APPENDIX D}

\section{TANK WASTE REMEDIATION SYSTEM (TWRS) SYSTEMS ENGINEERING- ASSESSMENT QUESTIONNAIRE}

NOTE: All questions used in this Information Systems Assessment report are marked with an asterisk ("*").

1.0 The Management Process Category, consisting of the following subject areas:
1.1. Planning
1.2 Tracking and Oversight
1.3 Subcontract Management
1.4 Intergroup Coordination
1.5 Configuration Management
1.6 Quality Management
1.7 Risk Management
1.8 Data Management

2.0 The Organization Process Category, consisting of the following subject areas:
2.1 Process Management and Improvement
2.2 Competency Development
2.3 Technology Management
2.4 System Engineering Tools and Environment Support

3.0 The Systems Engineering Process Category, consisting of the following subject areas:
3.1 System Concept Definition
3.2 Requirements and Functional Analysis
3.3 System Design
3.4 Integrated Engineering Analysis
3.5 System Integration
3.6 System Verification
3.7 System Validation

Descriptions of each of the subject areas are found at the beginning of each section of the questionnaire. 
AGA

Configuration Item

Drawing Tree

Environment

Event-Driven Plan

Formal Review

ICD

Life Cycle

Metrics

MOA

MYWP

OJT

Planning and Control Metric

Program
Alternatives Generation and Analysis - the process of establishing a comprehensive set of alternatives, evaluating the alternatives against selection criteria and selecting the "best" alternatives.

A collection of hardware elements treated as a unit for the purpose of configuration management.

A hierarchical list of drawings from a system master drawing down to individual component drawings.

The aggregate of technological, process, social and cultural conditions that influence the development of a system.

A planning document in which the dependencies and performance of events are the driving elements of the schedule, as opposed to calendar time for each event, or time allowed.

A review that is conducted in accordance with an approved plan with established standards.

Interface Control Document - A document, representing a design agreement between interfacing hardware or software systems, which fully defines the interface. An ICD is placed under Configuration Control and is considered part of the baseline.

The entirety of the life span of a system, from initial preconceptual planning through decontamination and decommissioning.

A synthesis of multiple measurements for the purpose of defining a process characteristic. See also planning and control metric, systems engineering process metric, and/or technical performance measure.

Memorandum of Agreement--used to document organizational interfaces and agreement.

Multi-Year Work Plan

On-the-Job-Training - a form of practical training where the trainee learns while performing the actual job.

A combination of measurements used to provide periodic assessment of the progress and status of a project throughout its life-cycle.

The TWRS organization that is financially responsible for major mission elements and which establishes the execution strategy. 
Project

Risk Management

Risk Threshold

Specification Tree

SECAM

SEMP

Specialty Engineering

Discipline

Structured manner

Systems Engineering Process Metric

Technical

Management Plan

Technical

Performance Measure

Tool

WBS
The discrete work within the larger TWRS Project that has firmly established objectives (deliverables); budget (cost); and scheduled beginning, intermediate and ending milestones. A unique subset are line items which have constraints due to capital funding and reporting to the U. S. Congress.

An organized process to identify what can go wrong, to quantify and assess the significance of the event, and to implement/control the approach for preventing, mitigating or handling each risk identified.

A subjective assessment of the amount of risk that is tolerable. When the risk threshold is exceeded more aggressive risk mitigation efforts are required.

The hierarchical depiction of the specifications needed (planned or existing) for the TWRS systems development.

Systems Engineering Capability Assessment Model

Systems Engineering Management Plan

Engineering specialties such as reliability, logistics, human factors, maintainability, nuclear, safety, etc., needed to ensure that complete system requirements, alternatives and design solution are integrated in the project life-cycle.

A term used in the maturity assessment questionnaire to denote that a process, task or activity is performed in a logical manner according to a recognized procedure. The procedure may or may not be formally documented but the structure in the process should be traceable to a documented process recognized by the organization.

Measurements which provide a quantitative means of assessing the progress and status of the systems engineering effort on a project.

A project plan in which technical activities, work products, and schedules are documented (e.g., Project Management Plan, Project Execution Plan, work plan).

A design related factor, preferably quantitative, that can be applied in the evaluation of a system and/or sub-systems to assess and track the progress toward achieving technical objectives or requirements.

A process or mechanism (often a software program) used to facilitate the accomplishment of tasks associated with the synthesis, test, analysis, or maintenance of models, designs. and/or documentation associated with systems components.

Work Breakdown Structure 


\subsection{Planning}

This subject area is applicable to managers and systems engineers only.

Planning involves the identification of technical and programmatic requirements and constraints at the project level. These requirements define the technical and programmatic baseline

Planning includes:

- Project requirements definition

- Identification, integration, and scheduling of all engineering functions and tasks

- Work breakdown structure development

- Definition of organizational structure, roles and responsibilities (as it relates to the project)

- Descriptions of, or references to, key policies and procedures.

Baseline planning is documented in the Project Management Plan, Project Plan, or work plan. The planning process is defined in the TWRS Systems Engineering Management Plan (SEMP), TWRS Program Plan and related lower-tier planning documents (e.g., Test and Evaluation Plan, Risk Management Plan, Configuration Management Plan), as well as in calendar-based and event-driven plans, such as the Multi-Year Work Plan (MYWP) and the Level-0, Mid-Level, and Detail-Level logic diagrams for the site, TWRS, and individual projects and divisions.

General characteristics of planning include the following:

- Technical activities, work products, and scheduling are documented in a technical management plan (e.g., Project Management Plan, Project Execution Plan or work plan).

- A work breakdown structure (WBS) is established that identifies logical units of work to be managed at the project level.

- The technical project elements are integrated in a top-down, life-cycle, low-risk approach.

- Technical objectives are specified in a realistic manner, consistent with organization, cost, and scheduling constraints. 


\begin{tabular}{|c|c|c|c|c|}
\hline Number & Question & \begin{tabular}{l|l|l} 
& $\mathbf{N}$ \\
\end{tabular} & DN & NA \\
\hline $1.1-1.1$ & Is planning being accomplished in at least an informal manner? & & & \\
\hline $1.1-1.2$ & Is time allocated for planning activities on the project? & & & \\
\hline \multirow[t]{2}{*}{$1.1-1.3 *$} & $\begin{array}{l}\text { Is there a work breakdown structure for the project that defines } \\
\text { logical units of work to be managed at the project level? }\end{array}$ & & & \\
\hline & Number of questions in level one $=3$ & & & \\
\hline $1.1-2.1$ & $\begin{array}{l}\text { Does the project follow a written policy (may be part of a } \\
\text { broad-based policy) for implementing planning activities? }\end{array}$ & & & \\
\hline $1.1-2.2 *$ & $\begin{array}{l}\text { Is there an approved technical management plan (may be part of a } \\
\text { larger project plan) for the program (e.g., a SEMP)? }\end{array}$ & & & \\
\hline $1.1-2.3$ & Has responsibility been assigned for project planning? & & & \\
\hline $1.1-2.4$ & $\begin{array}{l}\text { Is the adequacy of resources (e.g., funding, staff, tools, etc.) } \\
\text { provided for performing planning activities assessed? }\end{array}$ & & & \\
\hline $1.1-2.5$ & $\begin{array}{l}\text { When planning skills are inadequate, are individuals involved in } \\
\text { planning activities trained in estimating and planning procedures } \\
\text { applicable to their areas of responsibility? }\end{array}$ & & & \\
\hline 1.1-2.6* & $\begin{array}{l}\text { When the technical management plan is not followed, are } \\
\text { deviations from the plan documented and the rationale recorded so } \\
\text { that decisions can be traced through the system or project life } \\
\text { cycle? }\end{array}$ & & & \\
\hline $1.1-2.7$ & Are planning activities performed in a structured manner? & & & \\
\hline $1.1-2.8$ & Are planning activities statused for conformance to the plan? & & & \\
\hline \multirow[t]{2}{*}{$1.1-2.9$} & $\begin{array}{l}\text { Are corrective actions initiated when project activities deviate } \\
\text { significantly from the plan? }\end{array}$ & & & \\
\hline & Number of questions in level two $=9$ & & & \\
\hline $1.1-3.1$ & $\begin{array}{l}\text { Is the technical management plan developed and approved } \\
\text { according to a formal procedure? }\end{array}$ & & . & \\
\hline $1.1-3.2 *$ & $\begin{array}{l}\text { Have system and/or project life cycles, with predefined stages of } \\
\text { manageable size, been identified or defined? }\end{array}$ & & & \\
\hline $1.1-3.3^{*}$ & $\begin{array}{l}\text { Is an event-driven plan (activity based or logic driven) developed } \\
\text { for the project? }\end{array}$ & & & \\
\hline $1.1-3.4^{*}$ & $\begin{array}{l}\text { Are the risks associated with the cost, resource, schedule, and } \\
\text { technical aspects of the system or project identified, assessed, and } \\
\text { mitigated? }\end{array}$ & & & \\
\hline $1.1-3.5$ & $\begin{array}{l}\text { Are formal reviews of the technical management plan conducted } \\
\text { to assess its completeness and correctness (i.e., that all phases of } \\
\text { the project are addressed in the context of the project life cycle)? }\end{array}$ & & & \\
\hline
\end{tabular}




\begin{tabular}{|l|l|l|l|l|l|}
\hline Number & \multicolumn{1}{|c|}{ Question } & Y & N & DN & NA \\
\hline $1.1-3.6$ & $\begin{array}{l}\text { Are planning processes standardized across the project or } \\
\text { organization? }\end{array}$ & & & \\
\hline $1.1-3.7$ & $\begin{array}{l}\text { Are guidelines provided to allow the project to tailor the standard } \\
\text { planning process for its specific needs? }\end{array}$ & Number of questions in level three = 7 & & & \\
\hline $1.1-4.1$ & $\begin{array}{l}\text { Has the "graded approach" referenced in the TWRS Systems } \\
\text { Engineering Management Plan (HNF-SD-WM-SEMP-002, } \\
\text { Rev. 1) been followed to establish the appropriate level of systems } \\
\text { engineering for the project? }\end{array}$ & Number of additional questions = 1 & & & \\
\hline
\end{tabular}

\subsection{Tracking and Oversight}

This subject area is applicable to managers and systems engineers only.

These functions consist of monitoring, evaluating, and (when necessary) adjusting the technical effort of a project to achieve objectives, goals, and plans. Tracking involves the measurement of project tasks identified in project plans: technical characteristics, project progress, systems engineering process activities, etc. Oversight includes development of meaningful metrics, assessment of the tracking metrics, and corrective intervention (where required).

There are generally three types of metrics within a project:

- Technical Performance Metrics (or measures such as the impermeability of immobilized glass logs), which are used to track key technical parameters throughout a development project

- Planning and control metrics (such as cost performance, earned value), which provide for an ongoing assessment of the health and status of the project throughout the life-cycle

- Systems engineering process metrics, which provide an indication of the quality and productivity of the systems engineering process as applied to a specific project.

General Characteristics of Tracking and Oversight are:

- Metrics are established in accordance with the established baseline.

- Management, technical, and process functions and tasks are monitored (i.e., tracked, assessed, and corrected) against the baseline.

- Work products and performance are evaluated against applicable requirements. 
- Corrective actions consistent with the baseline are taken when management, technical, and process problems and issues are identified.

\begin{tabular}{|c|c|c|c|c|c|}
\hline Number & Question & $\mathbf{Y}$ & $\mathbf{N}$ & DN & NA \\
\hline $1.2-1.1$ & $\begin{array}{l}\text { Is tracking and oversight being accomplished in at least an } \\
\text { informal manner? }\end{array}$ & & & & \\
\hline $1.2-1.2$ & $\begin{array}{l}\text { Are technical performance measures monitored and used by } \\
\text { management in at least an informal manner? }\end{array}$ & & & & \\
\hline $1.2-1.3^{*}$ & $\begin{array}{l}\text { Are planning and control metrics monitored and used in at } \\
\text { least an informal manner? }\end{array}$ & & & & \\
\hline \multirow[t]{2}{*}{$1.2-1.4$} & $\begin{array}{l}\text { Are tracking and oversight activities included in the project } \\
\text { baseline? }\end{array}$ & & & & \\
\hline & Number of questions in level one $=4$ & & & & \\
\hline $1.2-2.1$ & $\begin{array}{l}\text { Does the project follow a written policy (may be part of a } \\
\text { broad-based policy) for implementing tracking and oversight? }\end{array}$ & & & & \\
\hline $1.2-2.2$ & $\begin{array}{l}\text { Is there an approved plan (may be part of a larger technical } \\
\text { management plan) for the project to identify, monitor, and } \\
\text { evaluate metrics? }\end{array}$ & & & & \\
\hline $1.2-2.3$ & $\begin{array}{l}\text { Has the responsibility for establishing and managing tracking } \\
\text { and oversight activities been assigned? }\end{array}$ & & & & \\
\hline $1.2-2.4$ & $\begin{array}{l}\text { Is the adequacy of resources (e.g., funding, staff, tools, etc.) } \\
\text { provided for performing tracking and oversight activities } \\
\text { assessed? }\end{array}$ & & & & \\
\hline $1.2-2.5$ & $\begin{array}{l}\text { Are personnel trained in the objectives, procedures, and } \\
\text { methods for performing tracking and oversight activities? }\end{array}$ & & & & \\
\hline $1.2-2.6$ & Is tracking and oversight performed in a structured manner? & & & & \\
\hline $1.2-2.7$ & $\begin{array}{l}\text { Are tracking and oversight activities statused for conformance } \\
\text { to plans? }\end{array}$ & & & & \\
\hline \multirow[t]{2}{*}{$1.2-2.8$} & $\begin{array}{l}\text { Are corrective actions initiated when tracking and oversight } \\
\text { activities deviate significantly from the technical baseline? }\end{array}$ & & & & \\
\hline & Number of questions in level two $=8$ & & & & \\
\hline $1.2-3.1$ & $\begin{array}{l}\text { Are tracking and oversight activities planned, approved, and } \\
\text { established according to a formal procedure? }\end{array}$ & & & & \\
\hline $1.2-3.2 *$ & $\begin{array}{l}\text { Are the risks associated with cost, resource, schedule, and } \\
\text { technical aspects of the project tracked? }\end{array}$ & & & & \\
\hline $1.2-3.3$ & $\begin{array}{l}\text { Are formal reviews to address the accomplishments and results } \\
\text { of the engineering aspects of the project conducted at selected } \\
\text { milestones? }\end{array}$ & & & & \\
\hline
\end{tabular}


4773, Rev. 0

\begin{tabular}{|c|c|c|c|c|c|}
\hline Number & Question & $\mathbf{Y}$ & $\mathbf{N}$ & DN & NA \\
\hline $1.2-3.4$ & $\begin{array}{l}\text { Are metrics (technical performance measures, process and } \\
\text { control, and systems engineering process) defined according to } \\
\text { a formal procedure? }\end{array}$ & & & & \\
\hline $1.2-3.5 *$ & $\begin{array}{l}\text { Are project technical performance measures identified, } \\
\text { documented, and distributed to appropriate parties? }\end{array}$ & & & & \\
\hline $1.2-3.6$ & $\begin{array}{l}\text { Are technical performance measures included in the baseline, } \\
\text { evaluated, and reported according to a formal procedure? }\end{array}$ & & & & \\
\hline $1.2-3.7$ & $\begin{array}{l}\text { Are tracking and oversight processes standardized across the } \\
\text { organization? }\end{array}$ & & & & \\
\hline \multirow[t]{2}{*}{$1.2-3.8$} & $\begin{array}{l}\text { Are guidelines provided to allow the project to tailor the } \\
\text { standard tracking and oversight process for its specific needs? }\end{array}$ & & & & \\
\hline & Number of questions in level three $=8$ & & & & \\
\hline $1.2-4.1$ & $\begin{array}{l}\text { Does the project use HNF-IP-0842, Volume IV, Section } 2.4 \text {, } \\
\text { Technical Performance Measurement to establish and track key } \\
\text { technical performance parameters? }\end{array}$ & & & & \\
\hline $1.2-4.2^{*}$ & $\begin{array}{l}\text { Has a technical performance measurement assessment plan } \\
\text { been documented or is one planned for the project? }\end{array}$ & & & & \\
\hline \multirow[t]{2}{*}{$1.2-4.3^{*}$} & $\begin{array}{l}\text { Does a master measurement list exist or will one be developed } \\
\text { for the project? }\end{array}$ & & & & \\
\hline & Number of additional questions $=3$ & & & & \\
\hline
\end{tabular}

\subsection{Subcontract Management}

This subject area is applicable to managers only.

The purpose of subcontract management is to select and control subcontractors who will meet the defined needs of the subcontract. Subcontract management involves the functions of planning, requirements definition, subcontractor selection, technical quality control, and cost control. This function also includes the effective and efficient use of subcontractors to accomplish the technical project objective, within the framework of established and documented plans, procedures, and requirements which describe the products and processes being subcontracted.

General characteristics of subcontract management are:

- Subcontract management activities are planned

- The definition and downflow of subcontractor requirements are consistent with the technical and project requirements

- Technically qualified subcontractors are selected 
- The subcontractor's work products and performance are monitored and evaluated against commitments and project objectives as defined in the subcontract.

\begin{tabular}{|c|c|c|c|c|c|}
\hline Number & Question & $\mathbf{Y}$ & $\mathbf{N}$ & DN & NA \\
\hline $1.3-1.1$ & $\begin{array}{l}\text { Is subcontract management being accomplished in at least an } \\
\text { informal manner? }\end{array}$ & & & & \\
\hline $1.3-1.2$ & $\begin{array}{l}\text { Are subcontract management activities planned for the } \\
\text { project? }\end{array}$ & & & & \\
\hline $1.3-1.3$ & $\begin{array}{l}\text { When subcontractors are used on the project, are requirements } \\
\text { for the work documented as part of a contract? }\end{array}$ & & & & \\
\hline \multirow[t]{2}{*}{$1.3-1.4$} & $\begin{array}{l}\text { When requirements change, are the changes renegotiated with } \\
\text { the subcontractor and the changes documented as part of a } \\
\text { contract? }\end{array}$ & & & & \\
\hline & Number of questions in level one $=4$ & & & & \\
\hline $1.2-2.1$ & $\begin{array}{l}\text { Does the project follow a written policy (may be part of a } \\
\text { broad-based policy) for selecting, managing, and controlling } \\
\text { the subcontractor? }\end{array}$ & & & & \\
\hline $1.3-2.2$ & $\begin{array}{l}\text { Is there an approved plan (may be part of a larger technical } \\
\text { management plan) for the project to perform subcontract } \\
\text { management? }\end{array}$ & & & & \\
\hline $1.2-2.3$ & $\begin{array}{l}\text { Has the responsibility for establishing and managing the } \\
\text { subcontract been assigned? }\end{array}$ & & & & \\
\hline $1.3-2.4$ & $\begin{array}{l}\text { Is the adequacy of resources (e.g., funding, staff, tools, etc.) } \\
\text { provided for selecting the subcontractor and managing the } \\
\text { subcontract assessed? }\end{array}$ & & & & \\
\hline $1.3-2.5$ & $\begin{array}{l}\text { Are team leaders and other individuals who are involved in } \\
\text { establishing and managing the subcontract trained to perform } \\
\text { these activities? }\end{array}$ & & & & \\
\hline $1.3-2.6$ & $\begin{array}{l}\text { Is acceptance testing conducted as part of the delivery of the } \\
\text { subcontractor's products? }\end{array}$ & & & & \\
\hline $1.3-2.7$ & Is subcontract management performed in a structured manner? & & & & \\
\hline $1.3-2.8$ & $\begin{array}{l}\text { Are subcontract management activities statused for } \\
\text { conformance to plans? }\end{array}$ & & & & \\
\hline \multirow[t]{2}{*}{$1.3-2.9$} & $\begin{array}{l}\text { Are corrective actions initiated when subcontract management } \\
\text { activities deviate significantly from the plan? }\end{array}$ & & & & \\
\hline & Number of questions in level two $=9$ & & & & \\
\hline $1.3-3.1$ & $\begin{array}{l}\text { Is the work to be subcontracted defined and planned } \\
\text { according to a formal procedure? }\end{array}$ & & & & \\
\hline
\end{tabular}




\begin{tabular}{|c|c|c|c|c|c|}
\hline Number & Question & $\mathbf{Y}$ & $\mathbf{N}$ & $\mathbf{D N}$ & NA \\
\hline $1.3-3.2$ & $\begin{array}{l}\text { Is the contractual agreement between the prime contractor and } \\
\text { the subcontractor used as the basis for managing the } \\
\text { subcontract? }\end{array}$ & & & & \\
\hline $1.3-3.3$ & $\begin{array}{l}\text { Is there a clearly documented subcontract that is complete, } \\
\text { accurate, and unambiguous, for each subcontractor? }\end{array}$ & & & & \\
\hline $1.3-3.4$ & $\begin{array}{l}\text { Are the subcontractor's quality management activities used to } \\
\text { improve the subcontractor's products? }\end{array}$ & & & & \\
\hline $1.3-3.5$ & $\begin{array}{l}\text { Are discrepancies discovered during acceptance testing used } \\
\text { to improve the subcontractor's products? }\end{array}$ & & & & \\
\hline $1.3-3.6$ & $\begin{array}{l}\text { Are subcontract management processes standardized across } \\
\text { the organization? }\end{array}$ & & & & \\
\hline \multirow[t]{2}{*}{$1.3-3.7$} & $\begin{array}{l}\text { Are guidelines provided to allow the project to tailor the } \\
\text { standard subcontract management process for its specific } \\
\text { needs? }\end{array}$ & & & & \\
\hline & Number of questions in level three $=7$ & & & & \\
\hline
\end{tabular}

\subsection{Intergroup Coordination}

This subject area is applicable to managers and systems engineers only.

Intergroup coordination is the means of facilitating the effective communication and resolution of issues among diverse groups involved in project system development (hardware). These diverse groups include customers, suppliers, producers, engineers of various disciplines and specialties, and other stakeholders. Intergroup coordination involves the management of relationships, interfaces, communications, exchanges, and reviews of technical information that are needed to effectively and efficiently accomplish project objectives.

Intergroup coordination also includes the integration of specialty engineering disciplines (reliability, logistics, electrical, mechanical, etc.) to accomplish concurrent engineering, which integrates product and process requirements, organizes a project for efficiency and effectiveness, balances the project's communication infrastructure, and integrates the project's documentation infrastructure. Engineering, construction, operation, and field support work together in concurrent engineering to consider all elements of the product life cycle from conception through decontamination and disposal to define acceptable system solutions.

General characteristics of intergroup coordination are as follows.

- Intergroup coordination activities are planned.

- Communications lines between groups are defined and managed. 
- Technical and project issues are identified and resolved among affected groups.

- All stakeholders have the project and technical information they need, when they need it.

\begin{tabular}{|c|c|c|c|c|c|}
\hline Number & Question & $\mathbf{Y}$ & $\mathbf{N}$ & DN & NA \\
\hline 1.4-1.1* & $\begin{array}{l}\text { Is intergroup coordination being accomplished in at least an } \\
\text { informal manner? }\end{array}$ & & & & \\
\hline $1.4-1.2 *$ & Are there regular technical interchanges with the customer? & & & & \\
\hline $1.4-1.3 *$ & $\begin{array}{l}\text { Are intergroup coordination activities planned for the } \\
\text { project? }\end{array}$ & & & & \\
\hline \multirow[t]{2}{*}{ 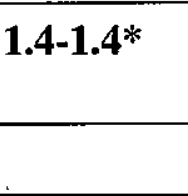 } & $\begin{array}{l}\text { Are both traditional and specialty engineering disciplines } \\
\text { involved in product development as needed? }\end{array}$ & & & & \\
\hline & Number of questions in level one $=4$ & & & & \\
\hline 1.4-2.1* & $\begin{array}{l}\text { Does the project follow a written policy (may be part of a } \\
\text { broad-based policy) for implementing intergroup } \\
\text { coordination? }\end{array}$ & & & & \\
\hline $1.4-2.2 *$ & $\begin{array}{l}\text { Is there an approved plan (may be part of a larger technical } \\
\text { management plan) for the project to perform intergroup } \\
\text { coordination? }\end{array}$ & & & & \\
\hline $1.4-2.3 *$ & $\begin{array}{l}\text { Has the responsibility for identifying, coordinating, and } \\
\text { resolving issues among different groups been assigned? }\end{array}$ & & & & \\
\hline $1.4-2.4 *$ & $\begin{array}{l}\text { Are technical and project intergroup coordination issues } \\
\text { called to the attention of the project manager? }\end{array}$ & & & & \\
\hline $1.4-2.5 *$ & $\begin{array}{l}\text { Is there an established process for escalation and arbitration } \\
\text { of technical differences, leading to resolution? }\end{array}$ & & & & \\
\hline $1.4-2.6 *$ & $\begin{array}{l}\text { Is the adequacy of resources (e.g., funding, staff, tools, etc.) } \\
\text { provided for performing intergroup coordination activities } \\
\text { assessed? }\end{array}$ & & & & \\
\hline $1.4-2.7 *$ & $\begin{array}{l}\text { Do personnel receive training in communication skills, } \\
\text { group problem-solving, and active listening? }\end{array}$ & & & & \\
\hline $1.4-2.8 *$ & $\begin{array}{l}\text { Is intergroup coordination being managed in a structured } \\
\text { manner? }\end{array}$ & & & & \\
\hline $1.4-2.9 *$ & $\begin{array}{l}\text { Are intergroup coordination activities statused for } \\
\text { conformance to plans? }\end{array}$ & & & & \\
\hline \multirow[t]{2}{*}{ 1.4-2.10* } & $\begin{array}{l}\text { Are corrective actions initiated when intergroup coordination } \\
\text { activities deviate significantly from the plan? }\end{array}$ & & & & \\
\hline & Number of questions in level two $=10$ & & & & \\
\hline 1.4-3.1* & Are intergroup coordination activities planned, approved, & & & & \\
\hline
\end{tabular}




\begin{tabular}{|l|l|l|l|l|l|}
\hline Number & \multicolumn{1}{|c|}{ Question } & Y & N & DN & NA \\
\hline & and established according to a formal procedure? & & & & \\
\hline $\mathbf{1 . 4 - 3 . 2 *}$ & $\begin{array}{l}\text { Do project personnel organize, conduct, and close formal } \\
\text { reviews of the system requirements? }\end{array}$ & & & \\
\hline $\mathbf{1 . 4 - 3 . 3 *}$ & $\begin{array}{l}\text { Are configuration items developed from system } \\
\text { requirements by appropriate teams? }\end{array}$ & $\begin{array}{l}\text { Are intergroup coordination processes standardized across } \\
\text { the organization? }\end{array}$ & & & \\
\hline $\mathbf{1 . 4 - 3 . 5 *}$ & $\begin{array}{l}\text { Are guidelines provided to allow the project to tailor the } \\
\text { standard intergroup coordination process for its specific } \\
\text { needs? }\end{array}$ & & & & \\
\hline & Number of questions in level three = 5 & & & \\
\hline
\end{tabular}

\subsection{Configuration Management}

This subject area is applicable to all participants.

Configuration management consists of the planning, configuration identification, change control, status accounting, and auditing of the product elements, which include requirements, interfaces, and design representations of the products being provided to meet stated project objectives.

- Planning involves developing, coordinating, and documenting the configuration management products and activities for identification, control, status accounting, and audits of the configured items.

- Identification involves the selection of documents which identify and describe the baseline configuration characteristics of an item during its life cycle.

- Control is a process for ensuring form/fit/function replacement, controlling physical interfaces, controlling design characteristics, assessing the impacts of proposed changes, and maintaining records of changes.

- Status accounting provides the recording and reporting of all changes to configuration baseline for the life of the system or project.

- Auditing at initial acceptance of a product involves verifying that the configuration documentation matches the approved physical configuration of the item and, at later stages of the life cycle, verifying that the physical configuration matches the approved documentation.

The general characteristics of configuration management are as follows. 
- Configuration management products and activities are planned.

- Configuration work products are identified, controlled, and available.

- Configuration changes are controlled and evaluated, consistent with the technical and project requirements.

- The status and contents of the configuration work products are communicated.

\begin{tabular}{|c|c|c|c|c|c|}
\hline Number & Question & $\mathbf{Y}$ & $\mathbf{N}$ & DN & NA \\
\hline $1.5-1.1$ & $\begin{array}{l}\text { Is configuration management being accomplished in at least } \\
\text { an informal manner? }\end{array}$ & & & & \\
\hline $1.5-1.2$ & $\begin{array}{l}\text { Is there a means to control the configuration items, } \\
\text { baselines, and all changes thereto? }\end{array}$ & & & & \\
\hline \multirow[t]{2}{*}{$1.5-1.3$} & $\begin{array}{l}\text { Are configuration management activities planned for the } \\
\text { project? }\end{array}$ & & & & \\
\hline & Number of questions in level one $=3$ & & & & \\
\hline $1.5-2.1$ & $\begin{array}{l}\text { Does the project follow a written policy (may be part of a } \\
\text { broad-based policy) for implementing configuration } \\
\text { management? }\end{array}$ & & & & \\
\hline $1.5-2.2$ & $\begin{array}{l}\text { Is there an approved plan (may be part of a larger technical } \\
\text { management plan) for the project to perform configuration } \\
\text { management? }\end{array}$ & & & & \\
\hline $1.5-2.3^{*}$ & $\begin{array}{l}\text { Are the work products to be placed under configuration } \\
\text { management identified? }\end{array}$ & & & & \\
\hline $1.5-2.4$ & $\begin{array}{l}\text { Has responsibility been established for managing } \\
\text { configuration items (e.g., configuration control board)? }\end{array}$ & & & & \\
\hline $1.5-2.5$ & $\begin{array}{l}\text { Has responsibility been assigned for coordinating and } \\
\text { implementing configuration management? }\end{array}$ & & & & \\
\hline $1-5.2 .6$ & $\begin{array}{l}\text { Is the adequacy of resources (i.e., funding, staff, tools, etc.) } \\
\text { provided for performing configuration management } \\
\text { activities assessed? }\end{array}$ & & & & \\
\hline $1.5-2.7$ & $\begin{array}{l}\text { Are engineering staff trained to perform their configuration } \\
\text { management activities? }\end{array}$ & & & & \\
\hline $1.5-2.8$ & $\begin{array}{l}\text { Is configuration management being performed in a } \\
\text { structured manner? }\end{array}$ & & & & \\
\hline $1.5-2.9$ & $\begin{array}{l}\text { Are configuration management activities statused for } \\
\text { conformance to plans? }\end{array}$ & & & & \\
\hline $1.5-2.10$ & Are corrective actions initiated when configuration & & & & \\
\hline
\end{tabular}




\begin{tabular}{|c|c|c|c|c|c|}
\hline Number & Question & $\mathbf{Y}$ & $\mathbf{N}$ & $\mathbf{D N}$ & NA \\
\hline & management activities deviate significantly from the plan? & & & & \\
\hline & Number of questions in level two $=10$ & & & & \\
\hline $1.5-3.1$ & $\begin{array}{l}\text { Are configuration management activities planned, approved, } \\
\text { and established according to a formal procedure? }\end{array}$ & & & & \\
\hline 1.5-3.2* & Is the status of configuration items recorded? & & & & \\
\hline $1.5-3.3$ & $\begin{array}{l}\text { Is a mechanism used for controlling changes to } \\
\text { system/subsystem/configuration item requirements? }\end{array}$ & & & & \\
\hline $1.5-3.4$ & $\begin{array}{l}\text { Is a formal procedure used for controlling changes to the } \\
\text { products which have completed baseline verification? }\end{array}$ & & & & \\
\hline $1.5-3.5$ & $\begin{array}{l}\text { Are configuration management processes standardized } \\
\text { across the organization? }\end{array}$ & & & & \\
\hline \multirow[t]{2}{*}{$1.5-3.6$} & $\begin{array}{l}\text { Are guidelines provided to allow the project to tailor the } \\
\text { standard configuration management process for its specific } \\
\text { needs? }\end{array}$ & & & & \\
\hline & Number of questions in level three $=6$ & & & & \\
\hline $1.5-4.1$ & $\begin{array}{l}\text { Does the project use HNF-1900, TWRS Configuration } \\
\text { Management Plan? }\end{array}$ & & & & \\
\hline \multirow[t]{2}{*}{$1.5-4.2$} & $\begin{array}{l}\text { Has a project specific configuration management } \\
\text { implementation plan been documented or will one be } \\
\text { prepared for the project? }\end{array}$ & & & & \\
\hline & Number of additional questions $=2$ & & & & \\
\hline
\end{tabular}

\subsection{Quality Management}

This subject area is applicable to all participants.

Quality management is the unifying set of activities that link human capabilities with engineering, production, support activities, and processes, to ensure that all stated needs are met. Quality management provides for independent evaluation and assessment of the products and processes used to meet project objectives. The results of these evaluations and assessments are reported to all who are impacted by them. The results are also used as a basis for adjusting the processes to achieve desired results and consistency. Reduction of variability and enhancement of design robustness are key elements of quality management.

General characteristics of quality management are as follows.

- Activities that affect quality are planned, executed, and checked.

- Technical efforts adhere to defined standards, procedures, and requirements.

- Noncompliance issues are addressed and tracked to closure. 
- Measurement of the processes provides for assessment of performance and correction to achieve desired results.

- Requirements and standards are evaluated and selected for application commensurate with the activity or product's need.

\begin{tabular}{|c|c|c|c|c|c|}
\hline Number & Question & $\mathbf{Y}$ & $\mathbf{N}$ & DN & NA \\
\hline $1.6-1.1 *$ & $\begin{array}{l}\text { Is quality management being accomplished in at least an } \\
\text { informal manner? }\end{array}$ & & & & \\
\hline \multirow[t]{2}{*}{ 1.6-1.2* } & Are quality management activities planned for the project? & & & & \\
\hline & Number of questions in level one $=2$ & & & & \\
\hline 1.6-2.1* & $\begin{array}{l}\text { Is there a quality policy (may be part of a broad-based policy) } \\
\text { that requires quality management be an integral part of all } \\
\text { activities? }\end{array}$ & & & & \\
\hline $1.6-2.2^{*}$ & $\begin{array}{l}\text { Is there a project specific Quality Assurance Program Plan (or } \\
\text { is one planned) for the project? }\end{array}$ & & & & \\
\hline $1.6-2.3^{*}$ & $\begin{array}{l}\text { Is an independent individual or group responsible for } \\
\text { performing quality assessment of project activities? }\end{array}$ & & & & \\
\hline $1.6-2.4^{*}$ & $\begin{array}{l}\text { Are the resources (e.g., funding, staff, tools, etc.) for } \\
\text { performing quality management activities periodically } \\
\text { assessed for adequacy? }\end{array}$ & & & & \\
\hline $1.6-2.5^{*}$ & $\begin{array}{l}\text { Are engineering personnel trained to perform their respective } \\
\text { quality management activities? }\end{array}$ & & & & \\
\hline $1.6-2.6^{*}$ & $\begin{array}{l}\text { Are quality management activities performed in a structured } \\
\text { manner? }\end{array}$ & & & & \\
\hline $1.6-2.7 *$ & $\begin{array}{l}\text { Are quality management activities statused for conformance } \\
\text { to plans? }\end{array}$ & & & & \\
\hline \multirow[t]{2}{*}{$1.6-2.8^{*}$} & $\begin{array}{l}\text { Are corrective actions initiated when quality management } \\
\text { activities deviate significantly from the plan? }\end{array}$ & & & & \\
\hline & Number of questions in level two $=8$ & & & & \\
\hline $1.6-3.1 *$ & $\begin{array}{l}\text { Are quality management activities planned, approved, and } \\
\text { established in a formal project specific Quality Assurance } \\
\text { Program Plan and/or a formal procedure? }\end{array}$ & & & & \\
\hline $1.6-3.2 *$ & $\begin{array}{l}\text { Do documented and approved quality assurance acceptance } \\
\text { criteria exist? }\end{array}$ & & & & \\
\hline $1.6-3.3^{*}$ & $\begin{array}{l}\text { Are quality management processes standardized across the } \\
\text { project organization? }\end{array}$ & & & & \\
\hline 1.6-3.4* & Are guidelines provided to allow the project to tailor the & & & & \\
\hline
\end{tabular}




\begin{tabular}{|r|r|r|r|l|l|}
\hline Number & Question & Y & N & DN & NA \\
\hline & standard quality management process for its specific needs? & & & \\
\hline & Number of questions in level three = 4 & & & \\
\hline $\mathbf{1 . 6 - 4 . 1 *}$ & $\begin{array}{l}\text { Are you familiar with HNF-IP-0842, Volume XI, Section 1.1, } \\
\text { TWRS Quality Assurance Program Plan? }\end{array}$ & & & \\
\hline & Number of additional questions = 1 & & & \\
\hline
\end{tabular}

\subsection{Risk Management}

This subject area is applicable to all participants.

Risk management is a technical and programmatic management process that addresses risks that may affect the technical, cost, and scheduling aspects of a project in an uncertain environment. Risk management involves three related activities: identification, analysis, and mitigation. All three are ongoing activities throughout the life cycle of a system or project. Risk identification is simply the continuous process of identifying what can go wrong in the project or system. Risk analysis consists of quantifying the probability of occurrence, determining the consequence of occurrence, and finding alternatives to avoid occurrence or consequence. Risk mitigation is the process of avoiding, reducing, controlling, or deliberately accepting risk.

General characteristics of risk management are as follows.

- Risk management is planned.

- Risks are identified and analyzed, and actions are taken to mitigate risks.

- Risks and mitigation actions are monitored.

- Risk status and mitigation efforts are communicated and coordinated across affected groups.

\begin{tabular}{|c|c|c|c|c|c|}
\hline Number & Question & $\mathbf{Y}$ & $\mathbf{N}$ & DN & NA \\
\hline $1.7-1.1^{*}$ & $\begin{array}{l}\text { Are risks being identified, analyzed, and mitigated in at least an } \\
\text { informal manner on the project? }\end{array}$ & & & & \\
\hline $1.7-1.2$ & Are risk management activities planned for the project? & & & & \\
\hline \multirow[t]{2}{*}{$1.7-1.3 *$} & Is the project manager made aware of significant risks? & & & & \\
\hline & Number of questions in level one $=3$ & & & & \\
\hline $1.7-2.1$ & $\begin{array}{l}\text { Does the project follow a written policy (may be part of a broad- } \\
\text { based policy) for implementing risk management? }\end{array}$ & & & & \\
\hline $1.7-2.2$ & $\begin{array}{l}\text { Is there an approved risk management plan (may be part of a } \\
\text { larger technical plan) for the project to identify, analyze, and }\end{array}$ & & & & \\
\hline
\end{tabular}




\begin{tabular}{|c|c|c|c|c|c|}
\hline Number & Question & $\mathbf{Y}$ & $\mathbf{N}$ & DN & NA \\
\hline & mitigate risk? & & & & \\
\hline $1.7-2.3$ & $\begin{array}{l}\text { Has responsibility been assigned for project risk management } \\
\text { activities? }\end{array}$ & & & & \\
\hline $1.7-2.4$ & $\begin{array}{l}\text { Is the adequacy of resources (e.g., funding, staff, tools, etc.) } \\
\text { provided for risk management activities assessed? }\end{array}$ & & & & \\
\hline $1.7-2.5$ & $\begin{array}{l}\text { Are engineering personnel trained to perform their respective } \\
\text { risk management activities? }\end{array}$ & & & & \\
\hline $1.7-2.6$ & Is risk management being performed in a structured manner? & & & & \\
\hline $1.7-2.7$ & $\begin{array}{l}\text { Are risk management activities statused (such as number of risks } \\
\text { identified) for conformance to plans? }\end{array}$ & & & & \\
\hline \multirow[t]{2}{*}{$1.7-2.8$} & $\begin{array}{l}\text { Are corrective actions initiated when risk management activities } \\
\text { deviate significantly from the plan? }\end{array}$ & & & & \\
\hline & Number of questions in level two $=8$ & & & & \\
\hline $1.7-3.1$ & $\begin{array}{l}\text { Are risk management activities planned, approved, and } \\
\text { established according to a formal procedure? }\end{array}$ & & & & \\
\hline $1.7-3.2$ & $\begin{array}{l}\text { Is there a well-defined method for evaluating risk associated } \\
\text { with key processes within the project (e.g. design, test, } \\
\text { manufacturing, etc.)? }\end{array}$ & & & & \\
\hline 1.7-3.3* & $\begin{array}{l}\text { Are risk thresholds established, which when exceeded, institute } \\
\text { more aggressive mitigation efforts? }\end{array}$ & & & & \\
\hline $1.7-3.4$ & $\begin{array}{l}\text { For each identified risk, is the potential impact to the project } \\
\text { assessed should the risk occur? }\end{array}$ & & & & \\
\hline $1.7-3.5$ & Is risk management a part of project formal reviews? & & & & \\
\hline $1.7-3.6$ & $\begin{array}{l}\text { Is the risk management process standardized across the } \\
\text { organization? }\end{array}$ & & & & \\
\hline \multirow[t]{2}{*}{$1.7-3.7$} & $\begin{array}{l}\text { Are guidelines provided to allow the project to tailor the } \\
\text { standard risk management process for its specific needs? }\end{array}$ & & & & \\
\hline & Number of questions in level three $=7$ & & & & \\
\hline $1.7-4.1$ & $\begin{array}{l}\text { Are you familiar with HNF-IP-0842, Volume IV, Section } 2.6 \text {, } \\
\text { Risk Management? }\end{array}$ & & & & \\
\hline $1.7-4.2$ & $\begin{array}{l}\text { Does the project have a project specific risk management plan or } \\
\text { will one be prepared? }\end{array}$ & & & & \\
\hline $1.7-4.3 *$ & Does the project use a risk management list? & & & & \\
\hline $1.7-4.4$ & $\begin{array}{l}\text { Are risks identified from application of the decision } \\
\text { management process? }\end{array}$ & & & & \\
\hline & Number of additional questions $=4$ & & & & \\
\hline
\end{tabular}


INF-4773, Rev. 0

\subsection{Data Management}

This subject area is applicable to all participants.

Data management is administrative control of project and system information in any form. Administrative control involves such activities as identification and interpretation of data requirements, planning, scheduling, controlling, archiving, and retrieving data.

Data management of documentation is required to support a project or system in areas such as:

- Administrative and financial

- Engineering and configuration

- Safety, logistics, and quality

- Manufacturing

- Procurement.

The data may take any form, such as:

- Reports, minutes, manuals, and charts

- Drawings, specifications, and Interface Control Documents (ICDs)

- Memorandums of agreement (MOAs)

- Correspondence

- Plans.

The data may be on any media, such as:

- Paper,

- Magnetic disk or diskette, or tape or cassette,

- Vellum, and

- Microfiche or microfilm.

All data products (deliverable and nondeliverable) should be received, logged, archived, recovered, transmitted, and distributed according to a data management plan (which may be part of a larger project or program plan). 


\section{RPP}

General characteristics of data management are:

- Data management products and activities are planned

- Project data are identified, controlled, inspected, archived, and retrieved, as appropriate

- Data items changes are controlled and evaluated consistent with the technical, programmatic, and configuration management requirement

- The status and contents of the project data are communicated to those who need them.

\begin{tabular}{|c|c|c|c|c|c|}
\hline Number & Question & $\mathbf{Y}$ & $\mathbf{N}$ & $\mathbf{D N}$ & NA \\
\hline $1.8-1.1$ & $\begin{array}{l}\text { Is data management being accomplished in at least an informal } \\
\text { manner? }\end{array}$ & & & & \\
\hline $1.8-1.2 *$ & Is there a means of archiving and retrieving project data? & & & & \\
\hline 1.8-1.3* & $\begin{array}{l}\text { Are relationships between requirements and interface documents } \\
\text { used within various levels of project or system development } \\
\text { documented (e.g., by using a specification tree)? }\end{array}$ & & & & \\
\hline 1.8-1.4* & $\begin{array}{l}\text { Are relationships between drawings for each physical element of } \\
\text { the system documented (e.g., using drawing trees)? }\end{array}$ & & & & \\
\hline $1.8-1.5 *$ & $\begin{array}{l}\text { Are relationships between software elements and interfaces } \\
\text { documented? }\end{array}$ & & & & \\
\hline \multirow[t]{2}{*}{$1.8-1.6$} & Are data management activities planned for the project? & & & & \\
\hline & Number of questions in level one $=6$ & & & & \\
\hline $1.8-2.1$ & $\begin{array}{l}\text { Does the project follow a written policy (may be part of a broad- } \\
\text { based policy) for implementing data management? }\end{array}$ & & & & \\
\hline $1.8-2.2$ & $\begin{array}{l}\text { Is there an approved plan (may be part of a larger technical } \\
\text { management plan) for the project to perform data management? }\end{array}$ & & & & \\
\hline $1.8-2.3$ & $\begin{array}{l}\text { Has the responsibility for establishing and managing project data } \\
\text { been assigned? }\end{array}$ & & & & \\
\hline $1.8-2.4$ & $\begin{array}{l}\text { Is the adequacy of resources (e.g., funding, staff, tools, etc.) } \\
\text { provided for performing data management activities assessed? }\end{array}$ & & & & \\
\hline $1.8-2.5$ & $\begin{array}{l}\text { Are engineering personnel trained to perform their respective } \\
\text { data management activities? }\end{array}$ & & & & \\
\hline $1.8-2.6$ & Are project data requirements established? & & & & \\
\hline $1.8-2.7$ & Is data management being performed in a structured manner? & & & & \\
\hline $1.8-2.8$ & Are data management activities statused for conformance to & & & & \\
\hline
\end{tabular}


RPP

\begin{tabular}{|l|l|l|l|l|l|}
\hline Number & \multicolumn{1}{|c|}{ Question } & Y & N & DN & NA \\
\hline & plans? & & & \\
\hline $1.8-2.9$ & $\begin{array}{l}\text { Are corrective actions initiated when data management activities } \\
\text { deviate significantly from the plan? }\end{array}$ & & & \\
\hline $1.8-3.1$ & $\begin{array}{l}\text { Are data management activities planned, approved, and } \\
\text { established according to a formal procedure? }\end{array}$ & & & & \\
\hline $1.8-3.2$ & $\begin{array}{l}\text { Are project data requirements established based upon a common } \\
\text { or standard set of data requirements? }\end{array}$ & & & & \\
\hline $1.8-3.3$ & $\begin{array}{l}\text { Is a standard process used to control changes to data } \\
\text { requirements standards? }\end{array}$ & & & & \\
\hline $\mathbf{1 . 8 - 3 . 4 *}$ & $\begin{array}{l}\text { At any given point in time, can the status of project data under } \\
\text { data management be identified? }\end{array}$ & & & & \\
\hline $1.8-3.5$ & $\begin{array}{l}\text { Are data management processes standardized across the } \\
\text { organization? }\end{array}$ & & & & \\
\hline $1.8-3.6$ & $\begin{array}{l}\text { Are guidelines provided to allow the project to tailor the } \\
\text { standard data management process for its specific needs? }\end{array}$ & & & & \\
\hline & Number of questions in level three = 6 & & & \\
\hline
\end{tabular}

\subsection{The Organization Process Category, consisting of the following subject areas:}

- Process Management and Improvement

- Competency Development

- Technology Management

- Systems Engineering Tools and Environment Support

\subsection{Process Management and Improvement}

This subject area is applicable to managers and systems engineers only.

Process management involves those activities needed to establish and maintain the processes required to accomplish systems engineering. Process management and improvement involves establishing process-related criteria and improvement criteria for systems engineering activities independent of any particular project. These criteria take the form of company or program policies and standards for the performance of systems engineering processes. Process management establishes engineering and quality standards and guidelines for systems engineering and for the tracking and improvement of the systems engineering processes. 
General characteristics of process management and improvement are:

- Process management and improvement activities are planned.

- An organization-wide family of standard systems engineering processes is established.

- Guidelines are established for tailoring the organization's standard systems engineering processes into a project-specific systems engineering process.

- An organization-wide repository for systems engineering process-related information is established and maintained.

- Information from project and organizational sources is used to continuously improve the organization's standard systems engineering processes and to integrate processes which interact with one another.

- Processes are established with the intent to cause project objectives to be realized.

- Project objectives are established and drive the creation of associated processes.

\begin{tabular}{|c|c|c|c|c|c|}
\hline Number & Question & $\mathbf{Y}$ & $\mathbf{N}$ & $\mathbf{D N}$ & NA \\
\hline $2.1-1.1$ & $\begin{array}{l}\text { Is systems engineering process management being } \\
\text { accomplished in at least an informal manner? }\end{array}$ & & & & \\
\hline $2.1-1.2$ & Are systems engineering processes being identified? & & & & \\
\hline \multirow[t]{2}{*}{$2.1-1.3$} & $\begin{array}{l}\text { Are systems engineering process management activities } \\
\text { planned for the organization? }\end{array}$ & & & & \\
\hline & Number of questions in level one $=3$ & & & & \\
\hline $2.1-2.1$ & $\begin{array}{l}\text { Does the organization follow a written policy (may be part of } \\
\text { a broad-based policy) for implementing and maintaining its } \\
\text { systems engineering process? }\end{array}$ & & & & \\
\hline $2.1-2.2$ & $\begin{array}{l}\text { Is there an approved systems engineering process } \\
\text { improvement plan (stand-alone or part of the systems } \\
\text { engineering process)? }\end{array}$ & & & & \\
\hline $2.1-2.3$ & $\begin{array}{l}\text { Is there a designated systems engineering manager or team } \\
\text { leader responsible for process management? }\end{array}$ & & & & \\
\hline $2.1-2.4$ & $\begin{array}{l}\text { Is the adequacy of resources periodically assessed (e.g., } \\
\text { funding, staff, tools) for performing systems engineering } \\
\text { process management and improvement activities? }\end{array}$ & & & & \\
\hline $2.1-2.5$ & $\begin{array}{l}\text { Is training provided to personnel involved in systems } \\
\text { engineering process management and improvement? }\end{array}$ & & & & \\
\hline $2.1-2.6$ & Is systems engineering process management and & & & & \\
\hline
\end{tabular}




\begin{tabular}{|c|c|c|c|c|c|}
\hline Number & Question & $\mathbf{Y}$ & $\mathbf{N}$ & DN & NA \\
\hline & improvement performed in a structured manner? & & & & \\
\hline $2.1-2.7$ & $\begin{array}{l}\text { Are systems engineering process management and } \\
\text { improvement activities statused for conformance to plans? }\end{array}$ & & & & \\
\hline \multirow[t]{2}{*}{$2.1-2.8$} & $\begin{array}{l}\text { Are corrective actions initiated when process management } \\
\text { and improvement activities deviate significantly from the } \\
\text { plan? }\end{array}$ & & & & \\
\hline & Number of questions in level two $=8$ & & & & \\
\hline $2.1-3.1$ & $\begin{array}{l}\text { Are process management and improvement activities } \\
\text { planned, approved, and established according to a formal } \\
\text { procedure? }\end{array}$ & & & & \\
\hline $2.1-3.2$ & $\begin{array}{l}\text { Has a standard systems approach been documented by the } \\
\text { organization? }\end{array}$ & & & & \\
\hline 2.1-3.3* & $\begin{array}{l}\text { Are the inputs and outputs of systems engineering process } \\
\text { activities clearly defined (e.g., in Project Management Plan, } \\
\text { detailed logic diagrams, work plans, Systems Engineering } \\
\text { Management Plan)? }\end{array}$ & & & & \\
\hline $2.1-3.4$ & $\begin{array}{l}\text { Are initiation and completion criteria defined for each major } \\
\text { activity in the systems engineering process? }\end{array}$ & & & & \\
\hline $2.1-3.5$ & $\begin{array}{l}\text { Does the organization seek to benchmark its systems } \\
\text { engineering process against processes used by other } \\
\text { organizations? }\end{array}$ & & & & \\
\hline $2.1-3.6$ & $\begin{array}{l}\text { Does the organization have a standard systems engineering } \\
\text { process? }\end{array}$ & & & & \\
\hline 2.1-3.7 & $\begin{array}{l}\text { Does the standard systems engineering process permit } \\
\text { tailoring to meet specific project needs? }\end{array}$ & & & & \\
\hline $2.1-3.8$ & $\begin{array}{l}\text { Does the project use the organization's defined systems } \\
\text { engineering process? }\end{array}$ & & & & \\
\hline $2.1-3.9$ & $\begin{array}{l}\text { Are formal methods for systems engineering used on } \\
\text { projects? }\end{array}$ & & & & \\
\hline \multirow[t]{2}{*}{$2.1-3.10$} & $\begin{array}{l}\text { Is a single process management and improvement process } \\
\text { standardized across the organization? }\end{array}$ & & & & \\
\hline & Number of questions in level three $=10$ & & & & \\
\hline 2.1-4.1 & Are organizational objectives established? & & & & \\
\hline \multirow[t]{2}{*}{$2.1-4.2$} & Are organizational objectives used to establish processes? & & & & \\
\hline & Number of additional questions $=2$ & & & & \\
\hline
\end{tabular}




\subsection{Competency Development}

This subject area is applicable to managers only.

The main components of competency development include a managed competency development program, documented plans, personnel with appropriate mastery of their engineering skills, and mechanisms for measuring the effectiveness of the development program.

The purpose of competency development is to:

- Increase organizational and project competency (as opposed to hiring needed talent) to perform the style, scope, and intensity of engineering required over time

- Provide a learning environment for individuals who want to increase their knowledge, skills, wisdom, competency, or mastery of engineering, project integration, and management.

Competency development occurs on three levels:

- University education

- Company-sponsored training

- On-the-job (OJT) experiences.

The competency development process consists of a managed program, needs forecasting and analysis, development plans, courseware, proficiency tests and standards, and sponsor/alumni feedback mechanisms to measure the effectiveness of the program.

General characteristics of competency development are as follows.

- Competency development activities are planned and managed.

- Competency development activities meet the needs of the organization, project, and individual.

- Competency development achievement levels are measured to determine effectiveness and to provide feedback for process improvement.

\begin{tabular}{|l|l|c|c|c|c|}
\hline Number & \multicolumn{1}{|c|}{ Question } & Y & N & DN & NA \\
\hline $2.2-1.1$ & $\begin{array}{l}\text { Is competency development being accomplished in at least an } \\
\text { informal manner? }\end{array}$ & & & & \\
\hline $2.2-1.2$ & Are competency development activities planned for the & & & & \\
\hline
\end{tabular}




\begin{tabular}{|c|c|c|c|c|c|}
\hline Number & Question & $\mathbf{Y}$ & $\mathbf{N}$ & $\mathbf{D N}$ & NA \\
\hline & organization? & & & & \\
\hline & Number of questions in level one $=2$ & & & & \\
\hline $2.2-2.1$ & $\begin{array}{l}\text { Does the organization follow a written policy (may be part of a } \\
\text { broad-based policy) for implementing competency development? }\end{array}$ & & & & \\
\hline $2.2-2.2$ & $\begin{array}{l}\text { Is there an approved plan (may be part of a larger technical } \\
\text { management plan) for the organization to perform competency } \\
\text { development? }\end{array}$ & & & & \\
\hline $2.2-2.3$ & $\begin{array}{l}\text { Is there a designated manager or team leader responsible for the } \\
\text { management of competency development? }\end{array}$ & & & & \\
\hline $2.2-2.4$ & $\begin{array}{l}\text { Are long-term competency development needs based upon the } \\
\text { organization's strategic plan? }\end{array}$ & & & & \\
\hline $2.2-2.5$ & $\begin{array}{l}\text { Are near-term competency development needs based upon } \\
\text { immediate project needs? }\end{array}$ & & & & \\
\hline $2.2-2.6$ & $\begin{array}{l}\text { Is the adequacy of resources (e.g., funding, staff, tools, etc.) } \\
\text { provided for performing competency development activities } \\
\text { assessed? }\end{array}$ & & & & \\
\hline $2.2-2.7$ & $\begin{array}{l}\text { When skills are inadequate, is training provided to members of } \\
\text { the competency development team? }\end{array}$ & & & & \\
\hline $2.2-2.8$ & $\begin{array}{l}\text { Is competency development being performed in a structured } \\
\text { manner? }\end{array}$ & & & & \\
\hline $2.2-2.9$ & $\begin{array}{l}\text { Are competency development activities statused for conformance } \\
\text { to plans? }\end{array}$ & & & & \\
\hline \multirow[t]{2}{*}{$2.2-2.10$} & $\begin{array}{l}\text { Are corrective actions initiated when competency development } \\
\text { activities deviate significantly from the plan? }\end{array}$ & & & & \\
\hline & Number of questions in level two $=10$ & & & & \\
\hline $2.2-3.1$ & $\begin{array}{l}\text { Are competency development activities planned, approved, and } \\
\text { established according to a formal procedure? }\end{array}$ & & & & \\
\hline $2.2-3.2$ & $\begin{array}{l}\text { Is there a mechanism for identifying competency development } \\
\text { needs within the organization? }\end{array}$ & & & & \\
\hline $2.2-3.3$ & $\begin{array}{l}\text { Are first-line managers, team leaders, and engineers trained on } \\
\text { the organization's standard systems engineering process? }\end{array}$ & & & & \\
\hline $2.2-3.4$ & $\begin{array}{l}\text { Are competency development processes standardized across the } \\
\text { organization? }\end{array}$ & & & & \\
\hline \multirow[t]{2}{*}{$2.2-3.5$} & $\begin{array}{l}\text { Are guidelines provided to allow the project to implement } \\
\text { competency development for its specific needs? }\end{array}$ & & & & \\
\hline & Number of questions in level three $=5$ & & & & \\
\hline
\end{tabular}




\subsection{Technology Management}

This subject area is applicable to all participants.

Technology management involves identifying, selecting, evaluating, and investing in new technologies, and incorporating the appropriate technologies into the organization's products and processes. By maintaining an awareness of product/process technology innovations throughout the world, and systematically evaluating and experimenting with them, the organization selects appropriate technologies to improve its competitiveness and increase both productivity and product quality. Pilot efforts are performed to assess new and unproven technologies before they are introduced across the organization and, where required, investments are made to increase the maturity of the technology. With appropriate sponsorship by the organization's management along with demonstrated performance, the selected technologies are incorporated into the organization's products and standard processes.

General characteristics of technology management are as follows.

- The organization has a process for maintaining technology awareness.

- The organization uses Alternatives Generation and Analysis (trade studies) to establish technology performance requirements and technology selection criteria.

- Selection of product and process technologies is planned according to the organization's needs.

- Investments are made to increase technology maturity.

- Technology innovations directly enable or improve the organization's standard products, services, and processes.

\begin{tabular}{|l|l|l|l|l|l|}
\hline Number & \multicolumn{1}{|c|}{ Question } & Y & N & DN & NA \\
\hline $2.3-1.1$ & $\begin{array}{l}\text { Is technology management being accomplished in at least } \\
\text { an informal manner? }\end{array}$ & & & \\
\hline $2.3-1.2$ & $\begin{array}{l}\text { Are technology management activities planned for the } \\
\text { organization? }\end{array}$ & & & & \\
\hline $2.3-2.1$ & $\begin{array}{l}\text { Noes the organization follow a written policy (may be part } \\
\text { of a broad-based policy) for technology management? }\end{array}$ & & & \\
\hline $2.3-2.2$ & $\begin{array}{l}\text { Is there an approved plan (may be part of a larger technical } \\
\text { management plan) for the organization to perform } \\
\text { technology management? }\end{array}$ & & & \\
\hline $2.3-2.3$ & Is responsibility designated for technology management? & & & \\
\hline
\end{tabular}




\begin{tabular}{|c|c|c|c|c|c|}
\hline Number & Question & $\mathbf{Y}$ & $\mathbf{N}$ & DN & NA \\
\hline 2.3-2.4 & $\begin{array}{l}\text { Is the adequacy of resources (e.g., funding, staff, tools, etc.) } \\
\text { provided for technology management activities assessed? }\end{array}$ & & & & \\
\hline $2.3-2.5$ & $\begin{array}{l}\text { When skills are inadequate, is technology management } \\
\text { training provided? }\end{array}$ & & & & \\
\hline $2.3-2.6$ & $\begin{array}{l}\text { Is technology management being performed in a structured } \\
\text { manner? }\end{array}$ & & & & \\
\hline $2.3-2.7$ & $\begin{array}{l}\text { Are technology management activities statused for } \\
\text { conformance to plans? }\end{array}$ & & & & \\
\hline \multirow[t]{2}{*}{$2.3-2.8$} & $\begin{array}{l}\text { Are corrective actions initiated when technology } \\
\text { management activities deviate significantly from the plan? }\end{array}$ & & & & \\
\hline & Number of questions in level two $=8$ & & & & \\
\hline $2.3-3.1$ & $\begin{array}{l}\text { Are technology management activities planned, approved, } \\
\text { and established according to formal procedure? }\end{array}$ & & & & \\
\hline $2.3-3.2$ & $\begin{array}{l}\text { Is a mechanism used for identifying and replacing obsolete } \\
\text { technologies? }\end{array}$ & & & & \\
\hline $2.3-3.3$ & $\begin{array}{l}\text { Are technology management processes standardized across } \\
\text { the organization? }\end{array}$ & & & & \\
\hline \multirow[t]{2}{*}{$2.3-3.4$} & $\begin{array}{l}\text { Are guidelines provided to allow the project to incorporate } \\
\text { technology management as appropriate for its specific } \\
\text { needs? }\end{array}$ & & & & \\
\hline & Number of questions in level three $=4$ & & & & \\
\hline $2.3-4.1$ & $\begin{array}{l}\text { Are there clearly defined responsibilities for technology } \\
\text { management? }\end{array}$ & & & & \\
\hline $2.3-4.2$ & $\begin{array}{l}\text { Is technology evaluation a well-defined part of the baseline } \\
\text { decision making process? }\end{array}$ & & & & \\
\hline \multirow[t]{2}{*}{$2.3-4.3$} & $\begin{array}{l}\text { Are technology performance goals and selection criteria } \\
\text { established? }\end{array}$ & & & & \\
\hline & Number of additional questions $=3$ & & & & \\
\hline
\end{tabular}




\subsection{Systems Engineering Tools and Environment Support}

This subject area is applicable to managers and systems engineers only.

Systems engineering tools and environment support includes managing the efficiency and effectiveness of the existing systems engineering tools and environment; forecasting, planning, and acquiring new tools; and tailoring the existing environment and tools for each projects needs. Responsibility for supporting the tools and environment must be defined, and the environment and tools should be changed or upgraded according to a documented plan, based on the organization's goals and project requirements.

System engineering tools may be categorized as follows:

- Requirements management

- Requirements analysis

- Modeling and simulation

- Change management

- Verification.

Requirements management tools are used to establish and maintain the relationships between technical aspects (e.g., requirements, functions, architecture, components, verification methods) and management aspects (e.g., work tasks, resources, organizational structure, facilities) of the project.

General characteristics of Systems Engineering Tools and Environment Support are as follows.

- Tool and environment support activities are planned.

- Engineers are provided an environment with a set of tools which support an established systems engineering process.

- The tools and environment can be tailored to a projects needs

- Improvement to the tool set and environment are implemented in a controlled manner.

\begin{tabular}{|l|l|c|c|c|c|}
\hline Number & \multicolumn{1}{|c|}{ Question } & Y & N & DN & NA \\
\hline $2.4-1.1$ & $\begin{array}{l}\text { Is environment and tool support for systems engineering } \\
\text { activities being accomplished in at least an informal } \\
\text { manner? }\end{array}$ & & & & \\
\hline $2.4-1.2$ & Are environment and tool support activities planned for the & & & & \\
\hline
\end{tabular}




\begin{tabular}{|c|c|c|c|c|c|}
\hline Number & Question & $\mathbf{Y}$ & $\mathbf{N}$ & DN & NA \\
\hline & organization? & & & & \\
\hline & Number of questions in level one $=2$ & & & & \\
\hline $2.4-2.1$ & $\begin{array}{l}\text { Is there a policy (may be part of a broad-based policy) } \\
\text { endorsing the use of a common environment and standard } \\
\text { tools for systems engineering activities? }\end{array}$ & & & & \\
\hline $2.4-2.2$ & $\begin{array}{l}\text { Is there a plan to provide resources to maintain and upgrade } \\
\text { facilities and tools in support of the systems engineering } \\
\text { environment? }\end{array}$ & & & & \\
\hline $2.4-2.3$ & $\begin{array}{l}\text { Have responsibilities been assigned to provide environment } \\
\text { and tool support for systems engineering activities? }\end{array}$ & & & & \\
\hline $2.4-2.4$ & $\begin{array}{l}\text { Is the adequacy of resources (e.g., funding, staff, tools) } \\
\text { provided to perform systems engineering environment and } \\
\text { tool support assessed? }\end{array}$ & & & & \\
\hline $2.4-2.5$ & $\begin{array}{l}\text { Are technical support personnel trained to perform } \\
\text { environment and tool support for the systems engineering } \\
\text { activities? }\end{array}$ & & & & \\
\hline $2.4-2.6$ & $\begin{array}{l}\text { Is environment and tool support for systems engineering } \\
\text { activities provided in a structured manner? }\end{array}$ & & & & \\
\hline $2.4-2.7$ & $\begin{array}{l}\text { Are environment and tool support activities statused for } \\
\text { conformance to plans? }\end{array}$ & & & & \\
\hline $2.4-2.8$ & $\begin{array}{l}\text { Are corrective actions initiated when environment and tool } \\
\text { support activities deviate significantly from the plan? }\end{array}$ & & & & \\
\hline & Number of questions in level two $=8$ & & & & \\
\hline $2.4-3.1$ & $\begin{array}{l}\text { Are environment and tool support activities planned, } \\
\text { approved, and established according to a formal procedure? }\end{array}$ & & & & \\
\hline $2.4-3.2$ & $\begin{array}{l}\text { Is a standard set of process and product data recorded } \\
\text { within the systems engineering environment? }\end{array}$ & & & & \\
\hline $2.4-3.3$ & $\begin{array}{l}\text { Are environment and tool support processes standardized } \\
\text { across the organization? }\end{array}$ & & & & \\
\hline $2.4-3.4$ & $\begin{array}{l}\text { Are guidelines provided to allow the project to tailor the } \\
\text { standard environment and tools for its specific needs? }\end{array}$ & & & & \\
\hline \multirow[t]{2}{*}{ 2.4-3.5 } & $\begin{array}{l}\text { Is the information provided by the tools used in } \\
\text { decision-making processes? }\end{array}$ & & & & \\
\hline & Number of questions in level three $=5$ & & & & \\
\hline
\end{tabular}


3.0 The Systems Engineering Process Category, consisting of the following subject areas:

- System Concept Definition

- Requirements and Functional Analysis

- System Design

- Integrated Engineering Analysis

- System Integration

- System Verification

- System Validation.

\subsection{System Concept Definition}

This subject area is applicable to all participants.

System concept definition consists of the following activities.

- Perform operations (or mission) analysis on the system requirements to understand the required behavior of the system.

- Derive alternative system concepts which unify system features, functions, performance, and price (or life-cycle cost of ownership). This is also referred to as Alternatives Generation and Analysis.

- Articulate alternative concepts sufficiently for selection of a preferred concept that is verified through formal concept review.

- Establish a system concept baseline.

At each step during system concept definition, alternative requirements, functions, and top-level physical/software architectural solutions are proposed. The system requirements are refined, analyzed, and synthesized only to a level of understanding that allows logical selection of the best alternative that will yield an optimal conceptual system that can be completely developed in successive stages of design.

General characteristics of system concept definition are as follows.

- System concept definition activities are planned. 
- Customer/user needs are negotiated and captured in the form of a user requirements baseline.

- The technical, scheduling, and economic feasibility of the system concept is established, and the rationale is documented.

- A preliminary system-level requirements and functional baseline is established that is traceable to customer/user requirements.

- A conceptual top-level physical/software architecture is established that is traceable to both the concept baseline and the customer/user requirements baseline, and the rationale is documented.

\begin{tabular}{|c|c|c|c|c|c|}
\hline Number & Question & $\mathbf{Y}$ & $\mathbf{N}$ & DN & NA \\
\hline $3.1-1.1$ & $\begin{array}{l}\text { Is system concept definition being performed in at least an } \\
\text { informal manner? }\end{array}$ & & & & \\
\hline $3.1-1.2$ & $\begin{array}{l}\text { Are system concept definition activities planned for the } \\
\text { project? }\end{array}$ & & & & \\
\hline 3.1-1.3* & $\begin{array}{l}\text { Are customer/user needs and constraints documented and } \\
\text { understood? }\end{array}$ & & & & \\
\hline \multirow[t]{2}{*}{ 3.1-1.4* } & $\begin{array}{l}\text { Are risk items associated with each system concept } \\
\text { considered? }\end{array}$ & & & & \\
\hline & Number of questions in level one $=4$ & & & & \\
\hline $3.1-2.1$ & $\begin{array}{l}\text { Does the project follow a written policy (may be part of a } \\
\text { broader policy) for implementing system concept definition } \\
\text { activities? }\end{array}$ & & & & \\
\hline $3.1-2.2$ & $\begin{array}{l}\text { Is there an approved plan (may be part of a larger technical } \\
\text { management plan) for the project to perform system } \\
\text { concept definition? }\end{array}$ & & & & \\
\hline $3.1-2.3$ & $\begin{array}{l}\text { Is there a designated engineering manager or team leader } \\
\text { responsible for system concept definition on the project? }\end{array}$ & & & & \\
\hline 3.1-2.4* & $\begin{array}{l}\text { Are customer/user needs captured in the form of a user } \\
\text { requirements baseline. }\end{array}$ & & & & \\
\hline $3.1-2.5$ & $\begin{array}{l}\text { Are risk items considered during trade studies of alternative } \\
\text { system concepts? }\end{array}$ & & & & \\
\hline $3.1-2.6$ & $\begin{array}{l}\text { Is functional analysis performed to establish a top-level } \\
\text { functional baseline completely traceable to the user } \\
\text { requirements baseline? }\end{array}$ & & & & \\
\hline $3.1-2.7$ & $\begin{array}{l}\text { Are trade studies (AGAs) performed to select between } \\
\text { alternative concepts? }\end{array}$ & & & & \\
\hline
\end{tabular}




\begin{tabular}{|c|c|c|c|c|c|}
\hline Number & Question & $\mathbf{Y}$ & $\mathbf{N}$ & DN & NA \\
\hline $3.1-2.8$ & $\begin{array}{l}\text { Are formal or informal reviews conducted on the system } \\
\text { concept and its allocated baseline? }\end{array}$ & & & & \\
\hline $3.1-2.9$ & $\begin{array}{l}\text { Is the adequacy of resources (e.g., funding, staff, tools, etc.) } \\
\text { provided for performing necessary engineering studies, } \\
\text { including prototype development (as required), assessed? }\end{array}$ & & & & \\
\hline $3.1-2.10$ & $\begin{array}{l}\text { When skills are inadequate, is training provided in system } \\
\text { concept definition? }\end{array}$ & & & & \\
\hline $3.1-2.11$ & $\begin{array}{l}\text { Is system concept definition and requirements flow down } \\
\text { performed in a structured manner on the project? }\end{array}$ & & & & \\
\hline $3.1-2.12$ & $\begin{array}{l}\text { Are system concept definition activities statused for } \\
\text { conformance to plans? }\end{array}$ & & & & \\
\hline \multirow[t]{2}{*}{$3.1-2.13$} & $\begin{array}{l}\text { Are corrective actions initiated when system concept } \\
\text { definition activities deviate significantly from the plan? }\end{array}$ & & & & \\
\hline & Number of questions in level two $=13$ & & & & \\
\hline $3.1-3.1$ & $\begin{array}{l}\text { Are system concept definition activities planned, approved, } \\
\text { and established according to a formal procedure? }\end{array}$ & & & & \\
\hline $3.1-3.2$ & $\begin{array}{l}\text { Are the customers/users of the system directly involved in } \\
\text { the definition of the system concept alternatives? }\end{array}$ & & & & \\
\hline $3.1-3.3$ & Is there a mechanism to assess concept feasibility? & & & & \\
\hline $3.1-3.4$ & $\begin{array}{l}\text { Are scenarios describing system operation developed for } \\
\text { each alternative system concept? }\end{array}$ & & & & \\
\hline $3.1-3.5$ & $\begin{array}{l}\text { Are scenarios describing life-cycle support developed for } \\
\text { each alternative system concept? }\end{array}$ & & & & \\
\hline $3.1-3.6$ & $\begin{array}{l}\text { Are system and operational concepts documented to a level } \\
\text { useful for deriving and validating system requirements? }\end{array}$ & & & & \\
\hline $3.1-3.7$ & $\begin{array}{l}\text { Are system concept definition processes standardized } \\
\text { across the organization? }\end{array}$ & & & & \\
\hline \multirow[t]{2}{*}{ 3.1-3.8 } & $\begin{array}{l}\text { Are guidelines provided to allow the project to tailor the } \\
\text { standard system concept definition process for its specific } \\
\text { needs? }\end{array}$ & & & & \\
\hline & Number of questions in level three $=8$ & & & & \\
\hline $3.1-4.1$ & $\begin{array}{l}\text { Does the project use HNF-IP-0842, Volume IV, Section } \\
\text { 3.3, Alternatives Generation and Analysis, to assess } \\
\text { alternatives and select system architectures? }\end{array}$ & & & & \\
\hline $3.1-4.2$ & $\begin{array}{l}\text { Have trade studies (AGAs) been performed for the project } \\
\text { or are they planned? }\end{array}$ & & & & \\
\hline
\end{tabular}




\begin{tabular}{|l|c|c|c|c|c|}
\hline Number & Question & Y & N & DN & NA \\
\hline & Number of additional questions = 2 & & & & \\
\hline
\end{tabular}

\subsection{Requirements and Functional Analysis}

This subject area is applicable to all participants.

The objective of requirements and functional analysis is to completely define the technical requirement for preferred system concept, in response to the customer/user needs. The major tasks of requirements and functional analysis are:

- Requirements analysis to successively lower levels: a structured or organized method to determine functional and performance requirements based on the customer/user requirements baseline. Prior requirements analyses are reviewed and updated at each level. Functional requirements identified are used as top-level functions for functional analysis.

- Functional analysis to successively lower levels: a structured or organized method to define and integrate a functional architecture to successively lower levels based on the developing lower-level requirements baseline. All specified uses for the system are considered, and a time line-analysis is generated for time-critical sequencing of functions. Prior analyses are reviewed and updated at each level. Input, output, and functional interfaces are defined.

- Requirements management: the activity of maintaining traceability from the customer/user requirements baseline to the successively developed, lower-level requirements that represent the system's capabilities.

- Requirements and functional flowdown: the activity of decomposing and allocating system level requirements and functions to successively lower-level functions of the system to satisfy the requirements and functional flowdown.

- Reexamination of mission and operational analysis: the activity of reanalyzing and documenting the customer/user's needs, as the system develops, through requirements and functional analysis activities, in terms of:

- $\quad$ accomplishing the system's mission or purpose and

- $\quad$ describing the system's intended operational characteristics.

- General characteristics of requirements and functional analysis are as follows:

- Development of subsystem requirements and functional architecture is planned.

- The customer/user requirements baseline is examined to ensure that expectations are realized and that requirements that cannot be met are resolved. 
- A complete system requirements baseline (including subsystems) is established and traceable to the customer/user requirements baseline.

- A complete functional architecture is established that is traceable to the system requirements baseline.

- Changes to requirements are controlled and communicated to affected groups.

\begin{tabular}{|c|c|c|c|c|c|}
\hline Number & Question & $\mathbf{Y}$ & $\mathbf{N}$ & DN & NA \\
\hline $3.2-1.1$ & $\begin{array}{l}\text { Is requirements analysis being accomplished by the project } \\
\text { in at least an informal manner? }\end{array}$ & & & & \\
\hline $3.2-1.2$ & $\begin{array}{l}\text { Is functional analysis being accomplished by the project in } \\
\text { at least an informal manner? }\end{array}$ & & & & \\
\hline $3.2-1.3$ & $\begin{array}{l}\text { Are requirements and functional analysis activities planned } \\
\text { for the project? }\end{array}$ & & & & \\
\hline 3.2-1.4* & $\begin{array}{l}\text { Are stakeholder constraints included in the user } \\
\text { requirements baseline? }\end{array}$ & & & & \\
\hline 3.2-1.5* & Are subsystem requirements documented? & & & & \\
\hline $3.2-1.6$ & $\begin{array}{l}\text { Is the functional architecture developed and is it related to, } \\
\text { and consistent with, the system and subsystem } \\
\text { requirements? }\end{array}$ & & & & \\
\hline $3.2-1.7$ & Is sequencing of time-critical functions considered? & & & & \\
\hline \multirow[t]{2}{*}{$3.2-1.8$} & $\begin{array}{l}\text { Are trade studies conducted during requirements and } \\
\text { functional analysis to select between competing } \\
\text { alternatives? }\end{array}$ & & & & \\
\hline & Number of questions in level one $=8$ & & & & \\
\hline $3.2-2.1$ & $\begin{array}{l}\text { Does the project follow a written policy (may be part of a } \\
\text { broad-based policy) that requires the management and } \\
\text { flowdown of system requirements and the development of } \\
\text { a corresponding functional architecture? }\end{array}$ & & & & \\
\hline $3.2-2.2$ & $\begin{array}{l}\text { Is there an approved project plan (may be part of a larger } \\
\text { technical management plan) describing how requirements } \\
\text { and functional analysis will be defined and managed? }\end{array}$ & & & & \\
\hline $3.2-2.3$ & $\begin{array}{l}\text { Is responsibility designated for the management of } \\
\text { requirements and functional analysis on the project? }\end{array}$ & & & & \\
\hline 3.2-2.4* & $\begin{array}{l}\text { Does the project perform a planned sequence of tasks to } \\
\text { transform customer/user expectations and constraints into a } \\
\text { system requirements baseline (including subsystem } \\
\text { requirements)? }\end{array}$ & & & & \\
\hline
\end{tabular}




\begin{tabular}{|c|c|c|c|c|c|}
\hline Number & Question & $\mathbf{Y}$ & $\mathbf{N}$ & DN & NA \\
\hline $3.2-2.5$ & $\begin{array}{l}\text { Are system-level requirements allocated and flowed down } \\
\text { to subsystems? }\end{array}$ & & & & \\
\hline $3.2-2.6$ & $\begin{array}{l}\text { Are trade studies performed to select between alternative } \\
\text { lower-level requirements? }\end{array}$ & & & & \\
\hline $3.2-2.7$ & Is the impact of system requirement changes evaluated? & & & & \\
\hline $3.2-2.8^{*}$ & $\begin{array}{l}\text { Is the system-level functional architecture reduced to } \\
\text { lower-level functions? }\end{array}$ & & & & \\
\hline $3.2-2.9$ & $\begin{array}{l}\text { Is requirements analysis conducted iteratively in } \\
\text { conjunction with functional analysis to develop lower-level } \\
\text { subsystem requirements? }\end{array}$ & & & & \\
\hline $3.2-2.10$ & $\begin{array}{l}\text { Are subsystem requirements traceable to the customer/user } \\
\text { requirements baseline? }\end{array}$ & & & & \\
\hline $3.2-2.11$ & $\begin{array}{l}\text { Is the adequacy of resources (e.g., funding, staff, tools, etc.) } \\
\text { provided for managing requirements and functional } \\
\text { analysis assessed? }\end{array}$ & & & & \\
\hline $3.2-2.12$ & $\begin{array}{l}\text { When skills are inadequate, is training provided in } \\
\text { requirements and functional analysis? }\end{array}$ & & & & \\
\hline $3.2-2.13$ & $\begin{array}{l}\text { Are subsystem requirements being developed in a } \\
\text { structured manner on the project? }\end{array}$ & & & & \\
\hline $3.2-2.14$ & $\begin{array}{l}\text { Are requirements and functional analysis activities statused } \\
\text { for conformance to plans? }\end{array}$ & & & & \\
\hline \multirow[t]{2}{*}{$3.2-2.15$} & $\begin{array}{l}\text { Are corrective actions initiated when requirements and } \\
\text { functional analysis activities deviate significantly from the } \\
\text { plan? }\end{array}$ & & & & \\
\hline & Number of questions in level two $=15$ & & & & \\
\hline $3.2-3.1$ & $\begin{array}{l}\text { Are requirements and functional analysis activities planned, } \\
\text { approved, and established according to a formal procedure? }\end{array}$ & & & & \\
\hline $3.2-3.2$ & $\begin{array}{l}\text { Are requirements and functional analysis managed } \\
\text { throughout the project's life cycle? }\end{array}$ & & & & \\
\hline $3.2-3.3$ & $\begin{array}{l}\text { Are standards applied to the generation and documentation } \\
\text { of subsystem requirements and the corresponding } \\
\text { subsystem functional architecture? }\end{array}$ & & & & \\
\hline $3.2-3.4$ & $\begin{array}{l}\text { Are requirements reviewed for completeness, feasibility } \\
\text { (risk), verifiability, clarity, and consistency before they are } \\
\text { incorporated into and committed by the project? }\end{array}$ & & & & \\
\hline
\end{tabular}




\begin{tabular}{|c|c|c|c|c|c|}
\hline Number & Question & $\mathbf{Y}$ & $\mathbf{N}$ & DN & NA \\
\hline $3.2-3.5^{*}$ & $\begin{array}{l}\text { Are verification criteria documented in conjunction with } \\
\text { the allocated requirements and corresponding functional } \\
\text { architecture? }\end{array}$ & & & & \\
\hline $3.2-3.6$ & $\begin{array}{l}\text { Are changes to the allocated requirements reviewed for } \\
\text { impact on feasibility, cost, schedule, risk, etc. before being } \\
\text { incorporated into the project? }\end{array}$ & & & & \\
\hline $3.2-3.7$ & $\begin{array}{l}\text { Are derived requirements traceable to analysis and design } \\
\text { rationale? }\end{array}$ & & & & \\
\hline $3.2-3.8$ & $\begin{array}{l}\text { Are relationships between requirements identified and } \\
\text { tracked in order to manage the impact of requirement } \\
\text { changes during the development process? }\end{array}$ & & & & \\
\hline $3.2-3.9$ & $\begin{array}{l}\text { Are nontechnical requirements (e.g., certification, safety, } \\
\text { produceability, etc.) managed and weighted with respect to } \\
\text { operational and functional requirements? }\end{array}$ & & & & \\
\hline $3.2-3.10$ & $\begin{array}{l}\text { Are standards for requirements traceability applied to the } \\
\text { project? }\end{array}$ & & & & \\
\hline $3.2-3.11$ & $\begin{array}{l}\text { Is a mechanism used for controlling changes to the system, } \\
\text { subsystem, and configuration item specifications? }\end{array}$ & & & & \\
\hline $3.2-3.12$ & $\begin{array}{l}\text { Is the process for requirements and functional analysis } \\
\text { standardized across the organization? }\end{array}$ & & & & \\
\hline \multirow[t]{2}{*}{$3.2-3.13$} & $\begin{array}{l}\text { Are guidelines provided to allow the project to tailor the } \\
\text { standard requirements and functional analysis process for } \\
\text { its specific needs? }\end{array}$ & & & & \\
\hline & Number of questions in level three $=13$ & & & & \\
\hline $3.2-4.1$ & $\begin{array}{l}\text { Does the project use HNF-IP-0842, Volume IV, Section } \\
\text { 3.2, Functions and Requirements Analysis and Allocation? }\end{array}$ & & & & \\
\hline & Number of additional questions $=1$ & & & & \\
\hline
\end{tabular}

\subsection{System Design}

This subject area is applicable to all participants.

System design is the process of transforming system requirements into design solutions, including conceptual and detailed design stages of the system life-cycle development.

Conceptual design includes the process of performing system analysis, requirements allocation, trade studies, optimization, system synthesis, and configuration definition in the form of the development of preliminary design specifications and architectural drawings for review and approval at conceptual design review. 
Detailed design activities begin with the concept and configuration derived through the conceptual design phase. Once the overall system design configuration has been established by conceptual design, further system definition activities define the details of the system and associated specifications and drawings.

General characteristics of system design are as follows.

- System design activities are planned.

- A system design baseline is established that satisfies the system requirements.

- The current system requirements are traceable to user requirements.

- System design rationale and other information are captured and made available within the organization.

- The system design is controlled and communicated to affected groups.

\begin{tabular}{|c|c|c|c|c|c|}
\hline Number. & Question & $\mathbf{Y}$ & $\mathbf{N}$ & $\mathbf{D N}$ & NA \\
\hline 3.3-1.1* & $\begin{array}{l}\text { Is system design being performed in at least an informal } \\
\text { manner? }\end{array}$ & & & & \\
\hline \multirow[t]{2}{*}{ 3.3-1.2* } & Are system design activities planned for the project? & & & & \\
\hline & Number of questions in level one $=2$ & & & & \\
\hline 3.3-2.1* & $\begin{array}{l}\text { Does the project follow a written policy (may be part of a } \\
\text { broad-based policy) for implementing the design process } \\
\text { for system and subsystem development? }\end{array}$ & & & & \\
\hline 3.3-2.2* & $\begin{array}{l}\text { Is there an approved plan (may be part of a larger technical } \\
\text { management plan) for the project to perform system } \\
\text { design? }\end{array}$ & & & & \\
\hline 3.3-2.3* & $\begin{array}{l}\text { Is there a designated engineering manager or team leader } \\
\text { responsible for the management of systems design on the } \\
\text { project? }\end{array}$ & & & & \\
\hline 3.3-2.4* & $\begin{array}{l}\text { Is there a mechanism to assure compliance with the } \\
\text { architecture guidelines and rules during design and } \\
\text { implementation? }\end{array}$ & & & & \\
\hline $3.3-2.5^{*}$ & $\begin{array}{l}\text { Are key system components traceable to the requirements } \\
\text { baseline? }\end{array}$ & & & & \\
\hline 3.3-2.6* & $\begin{array}{l}\text { Are trade studies (AGAs) performed to select between } \\
\text { candidate design alternatives when required? }\end{array}$ & & & & \\
\hline
\end{tabular}




\begin{tabular}{|c|c|c|c|c|c|}
\hline Number & Question & $\mathbf{Y}$ & $\mathbf{N}$ & DN & NA \\
\hline 3.3-2.7* & $\begin{array}{l}\text { When skills are inadequate, is training provided to } \\
\text { engineering personnel involved with system design? }\end{array}$ & & & & \\
\hline $3.3-2.8 *$ & $\begin{array}{l}\text { Are design issues addressed in formal and informal } \\
\text { reviews? }\end{array}$ & & & & \\
\hline $3.3-2.9 *$ & $\begin{array}{l}\text { Is system design accomplished on the project in a } \\
\text { structured manner? }\end{array}$ & & & & \\
\hline 3.3-2.10* & $\begin{array}{l}\text { Are system design activities statused for conformance to } \\
\text { plans? }\end{array}$ & & & & \\
\hline \multirow[t]{2}{*}{ 3.3-2.11* } & $\begin{array}{l}\text { Are corrective actions initiated when system design } \\
\text { activities deviate significantly from the plan? }\end{array}$ & & & & \\
\hline & Number of questions in level two $=11$ & & & & \\
\hline 3.3-3.1* & $\begin{array}{l}\text { Are system design activities planned, approved, and } \\
\text { established according to a formal procedure? }\end{array}$ & & & & \\
\hline 3.3-3.2* & $\begin{array}{l}\text { Are exit criteria for system design established at the } \\
\text { beginning of the project? }\end{array}$ & & & & \\
\hline 3.3-3.3* & $\begin{array}{l}\text { Are system design processes standardized across the } \\
\text { organization? }\end{array}$ & & & & \\
\hline \multirow[t]{2}{*}{ 3.3-3.4* } & $\begin{array}{l}\text { Are guidelines provided to allow the project to tailor the } \\
\text { standard system design process for its specific needs? }\end{array}$ & & & & \\
\hline & Number of questions in level three $=4$ & & & & \\
\hline
\end{tabular}

\subsection{Integrated Engineering Analysis}

This subject area is applicable to managers and systems engineers only.

Integrated engineering analysis is the utilization of multi-disciplinary teams representing multifunctional areas to perform engineering analysis.

The purpose of integrated engineering analysis is to accomplish the following:

- Identify issues that require the application of decision theory techniques to accomplish timely technical decision-making

- Select a decision-making technique appropriate to each technical issue

- Involve the right mix of technical disciplines in the decision-making process during development of the system.

Integrated engineering analysis involves uniting the efforts of various engineering disciplines to the tasks of trade studies and decisions processes, functional and requirements analysis, and the 


\section{$\stackrel{\text { RPP }}{\text { HNF-4773, Rev. } 0}$}

development of design solutions and verification methods. Integrated engineering analysis is used in all phases of a project from conceptual design through operational testing. Integrated engineering analysis teams include all traditional and specialty engineering disciplines.

General characteristics of integrated engineering analysis are as follows.

- Integrated engineering analysis activities are planned (i.e., alternatives defined, methodology established, selection criteria established) before they are accomplished.

- The environment promotes the integrated development of products and their related processes.

- Appropriate decision-making techniques are used to resolve technical issues.

- Relevant engineering/technical disciplines are combined, as appropriate, to participate in technical decision-making processes.

\begin{tabular}{|c|c|c|c|c|}
\hline Number & Question & \begin{tabular}{l|l}
$\mathbf{Y}$ & $\mathbf{N}$ \\
\end{tabular} & DN & NA \\
\hline $3.4-1.1$ & $\begin{array}{l}\text { Has the integration of engineering analysis been } \\
\text { implemented in at least an informal manner? }\end{array}$ & & & \\
\hline \multirow[t]{2}{*}{$3.4-1.2$} & $\begin{array}{l}\text { Are integrated engineering analysis activities planned for the } \\
\text { project? }\end{array}$ & & & \\
\hline & Number of questions in level one $=2$ & & & \\
\hline $3.4-2.1$ & $\begin{array}{l}\text { Does the project follow a written policy (may be part of a } \\
\text { broad-based policy) requiring integrated engineering analysis } \\
\text { activities? }\end{array}$ & & & \\
\hline $3.4-2.2$ & $\begin{array}{l}\text { Is there an approved plan (may be part of a larger project } \\
\text { plan) for the project that identifies integrated engineering } \\
\text { analysis activities? }\end{array}$ & & & \\
\hline $3.4-2.3$ & $\begin{array}{l}\text { Has the responsibility for coordinating integrated engineering } \\
\text { analysis activities been assigned? }\end{array}$ & & & \\
\hline $3.4-2.4$ & $\begin{array}{l}\text { Is the adequacy of resources (e.g., funding, staff, tools, etc.) } \\
\text { provided for integrated engineering analysis activities } \\
\text { assessed? }\end{array}$ & & & \\
\hline $3.4-2.5$ & $\begin{array}{l}\text { Are requirements and objectives for trades studies } \\
\text { established? }\end{array}$ & & & \\
\hline $3.4-2.6$ & $\begin{array}{l}\text { Are minimal trade study alternatives to be considered clearly } \\
\text { established? }\end{array}$ & & & \\
\hline $3.4-2.7$ & Are objective selection criteria for trade studies formulated? & & & \\
\hline
\end{tabular}




\begin{tabular}{|c|c|c|c|c|}
\hline Number & Question & $\mathbf{Y} \mathbf{N}$ & DN & NA \\
\hline $3.4-2.8$ & $\begin{array}{l}\text { Is integrated engineering analysis performed on the project in } \\
\text { a structured manner? }\end{array}$ & & & \\
\hline $3.4-2.9$ & $\begin{array}{l}\text { Are integrated engineering analysis activities statused for } \\
\text { conformance to the plan? }\end{array}$ & & & \\
\hline \multirow[t]{2}{*}{$3.4-2.10$} & $\begin{array}{l}\text { Are corrective actions initiated when integrated engineering } \\
\text { analysis activities deviate significantly from the plan? }\end{array}$ & & & \\
\hline & Number of questions in level two $=10$ & & & \\
\hline $3.4-3.1$ & $\begin{array}{l}\text { Are integrated engineering analysis activities planned, } \\
\text { approved, and established according to a formal procedure? }\end{array}$ & & & \\
\hline $3.4-3.2$ & $\begin{array}{l}\text { Is a mechanism used for ensuring traceability between the } \\
\text { system requirements and lower-level specification } \\
\text { requirements? }\end{array}$ & & & \\
\hline $3.4-3.3$ & $\begin{array}{l}\text { Is a mechanism used for ensuring traceability between the } \\
\text { system requirements and the top-level designs? }\end{array}$ & & & \\
\hline $3.4-3.4$ & $\begin{array}{l}\text { Is a mechanism established to identify risks for each } \\
\text { candidate solution? }\end{array}$ & & & \\
\hline $3.4-3.5$ & $\begin{array}{l}\text { Does the selected alternative meet all engineering and } \\
\text { technical requirements? }\end{array}$ & & & \\
\hline $3.4-3.6$ & $\begin{array}{l}\text { Are review criteria used to determine when requirements } \\
\text { analysis, design, integration, and verification are complete } \\
\text { for each system component? }\end{array}$ & & & \\
\hline $3.4-3.7$ & $\begin{array}{l}\text { Are a common set of metrics available for integrated } \\
\text { engineering analysis? }\end{array}$ & & & \\
\hline $3.4-3.8$ & $\begin{array}{l}\text { Are integrated engineering analysis processes standardized } \\
\text { (procedures, desk instructions, etc.) across the organization? }\end{array}$ & & & \\
\hline \multirow[t]{2}{*}{$3.4-3.9$} & $\begin{array}{l}\text { Are guidelines provided to allow the project to tailor the } \\
\text { standard integrated engineering analysis process for its } \\
\text { specific needs? }\end{array}$ & & & \\
\hline & Number of questions in level three $=9$ & & & \\
\hline \multirow[t]{2}{*}{$3.4-4.1$} & $\begin{array}{l}\text { Does the project use HNF-IP-0842, Volume IV, Section } 2.7 \text {, } \\
\text { Decision Management? }\end{array}$ & & & \\
\hline & Number of additional questions $=1$ & & & \\
\hline
\end{tabular}

\subsection{System Integration}

This subject area is applicable to all participants. 
System integration is managed by interface control documents, that ensure compatibility of all interfaces. System integration ensures that the subsystems perform as a complete system that satisfies the system level requirements within the defined operating environment. Coupling between subsystems is indicative of their interdependence; connectivity between subsystems correlates some or all of the internal elements of one subsystem to selected internal elements of another subsystem. System integration is the collection of documentation and processes that results in mutually compatible subsystems that collectively perform to the customer/user needs.

General characteristics of system integration are as follows.

- System integration is planned.

- Interface design enables subsystems to satisfy assigned system requirements.

- Information on interface design and design rationale is captured and made available within the project and organization.

- Interface design is controlled, communicated to affected groups, and used to support project decisions.

\begin{tabular}{|c|c|c|c|c|c|}
\hline Number & Question & $\mathbf{Y}$ & $\overline{\mathbf{N}}$ & $\overline{\mathrm{DN}}$ & NA \\
\hline $3.5-1.1$ & $\begin{array}{l}\text { Is system integration being accomplished in at least an } \\
\text { informal manner? }\end{array}$ & & & & \\
\hline $3.5-1.2$ & $\begin{array}{l}\text { Is incremental system integration being accomplished in at } \\
\text { least an informal manner? }\end{array}$ & & & & \\
\hline \multirow[t]{2}{*}{$3.5-1.3$} & Are system integration activities planned for the project? & & & & \\
\hline & Number of questions in level one $=3$ & & & & \\
\hline $3.5-2.1$ & $\begin{array}{l}\text { Does the project follow a written policy (may be part of a } \\
\text { broad-based policy) for implementing system integration? }\end{array}$ & & & & \\
\hline $3.5-2.2$ & $\begin{array}{l}\text { Does the policy require planning of system integration and } \\
\text { interface control? }\end{array}$ & & & & \\
\hline $3.5-2.3$ & $\begin{array}{l}\text { Is there an approved plan (may be part of a larger technical } \\
\text { management plan) for the project to perform system } \\
\text { integration? }\end{array}$ & & & & \\
\hline $3.5-2.4$ & $\begin{array}{l}\text { Is there a designated engineering manager or team leader } \\
\text { responsible for interface management on the project? }\end{array}$ & & & & \\
\hline $3.5-2.5$ & $\begin{array}{l}\text { Is adequacy of resources (e.g., funding, staff, tools, etc.) } \\
\text { provided to conduct system integration activities assessed } \\
\text { (independently from the adequacy of resources provided } \\
\text { for system design activities)? }\end{array}$ & & & & \\
\hline $3.5-2.6$ & Are interface issues addressed in design reviews? & & & & \\
\hline $3.5-2.7$ & $\begin{array}{l}\text { When skills are inadequate, is training provided to } \\
\text { engineering personnel involved in system integration? }\end{array}$ & & & & \\
\hline
\end{tabular}




\begin{tabular}{|c|c|c|c|c|c|}
\hline Number & Question & $\mathbf{Y}$ & $\mathbf{N}$ & DN & NA \\
\hline $3.5-2.8$ & $\begin{array}{l}\text { When multiple companies are involved, are clear roles and } \\
\text { responsibilities established for interface management? }\end{array}$ & & & & \\
\hline $3.5-2.9$ & $\begin{array}{l}\text { Is system integration accomplished on the project in a } \\
\text { structured manner? }\end{array}$ & & & & \\
\hline $3.5-2.10$ & $\begin{array}{l}\text { Is incremental system integration accomplished on the } \\
\text { project in a structured manner? }\end{array}$ & & & & \\
\hline $3.5-2.11$ & $\begin{array}{l}\text { Are system integration activities statused for conformance } \\
\text { to plans? }\end{array}$ & & & & \\
\hline \multirow[t]{2}{*}{$3.5-2.12$} & $\begin{array}{l}\text { Are corrective actions initiated when system integration } \\
\text { activities deviate significantly from the plan? }\end{array}$ & & & & \\
\hline & Number of questions in level two $=12$ & & & & \\
\hline $3.5-3.1$ & $\begin{array}{l}\text { Is the system integration plan developed and approved } \\
\text { according to a formal procedure? }\end{array}$ & & & & \\
\hline $3.5-3.2$ & $\begin{array}{l}\text { Does the system integration plan employ an incremental } \\
\text { integration approach? }\end{array}$ & & & & \\
\hline 3.5-3.3* & Are all interfaces identified and managed? & & & & \\
\hline $3.5-3.4$ & $\begin{array}{l}\text { Is interorganizational configuration management of the } \\
\text { interface control document(s) accomplished? }\end{array}$ & & & & \\
\hline $3.5-3.5$ & $\begin{array}{l}\text { Are system integration issues included as an integral part } \\
\text { of all formal, system-level design reviews? }\end{array}$ & & & & \\
\hline $3.5-3.6$ & $\begin{array}{l}\text { When multiple companies are involved in system } \\
\text { integration, do they follow a formal procedure for } \\
\text { conducting their integration activities? }\end{array}$ & & & & \\
\hline $3.5-3.7$ & $\begin{array}{l}\text { Are system integration processes standardized across the } \\
\text { organization? }\end{array}$ & & & & \\
\hline \multirow[t]{2}{*}{$3.5-3.8$} & $\begin{array}{l}\text { Are guidelines provided to allow the project to tailor the } \\
\text { standard system integration process for its specific needs? }\end{array}$ & & & & \\
\hline & Number of questions in level three $=8$ & & & & \\
\hline $3.5-4.1$ & $\begin{array}{l}\text { Does the project use HNF-IP-0842, Volume IV, Section } \\
\text { 2.8, Interface Control? }\end{array}$ & & 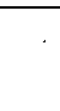 & & \\
\hline $3.5-4.2 *$ & $\begin{array}{l}\text { Have project interface control diagrams been prepared or } \\
\text { will they be? }\end{array}$ & & & & \\
\hline \multirow[t]{2}{*}{$3.5-4.3^{*}$} & $\begin{array}{l}\text { Has the project developed detailed logic diagrams to } \\
\text { document the predecessor/successor relationships of } \\
\text { project tasks and interfaces? }\end{array}$ & & & & \\
\hline & Number of additional questions $=3$ & & & & \\
\hline
\end{tabular}

\subsection{System Verification}

This subject area is applicable to managers and systems engineers only 
System verification is a stepwise approach to ensure that each element of the system satisfies its requirements. When completed at each level of the system hierarchy, it is ensured that the complete, integrated system satisfies the system level requirements. The system verification process is successfully applied to each of the components, units, and subsystems within the system to determine for a given level of development, that the implementation satisfies the requirements specified at that level and that interfaces are clearly defined in the interface control documents. When the system verification process is successfully applied to each of the components, units, and subsystems, there are two results: 1) the implementation satisfies the requirements specified at a given level of development; 2) interfaces are clearly defined in the interface control documents. Verification is accomplished by any one or a combination of the following methods: test, analysis, simulation, demonstration, inspection, or examination.

System verification is not a single event comprising a single test or a series of tests conducted at the conclusion of development. Developmental verification activities begin early in the life cycle and enable tracking and control of critical technical performance parameters that are the key to satisfying specification requirements. Developmental verification also facilitates detection of design deficiencies and interface issues, permitting timely resolution before such issues adversely affect scheduling and cost.

System verification usually has two components:

1. Functional system verification (system performance).

2. Physical system verification (configuration documentation).

Functional system verification includes system performance testing, and qualification testing, which verifies system performance within its specified operational environment (e.g., temperature, head pressure, viscosity). Physical system verification determines that the as-built configuration is physically in compliance with the specification(s) and referenced drawing(s).

General characteristics of system verification are as follows.

- System verification is planned.

- Actual performance of the system satisfies specified performance requirements.

- The system is able to perform in the specified environment.

- The as-built configuration of the system is as specified and documented.

- Verification activities within the project are performed in a consistent and coordinated manner. 


\begin{tabular}{|c|c|c|c|c|c|}
\hline Number & Question & $\mathbf{Y}$ & $\mathbf{N}$ & DN & NA \\
\hline $3.6-1.1$ & $\begin{array}{l}\text { Is system verification accomplished in at least an informal } \\
\text { manner? }\end{array}$ & & & & \\
\hline $3.6-1.2$ & $\begin{array}{l}\text { Is component and subsystem verification conducted in some } \\
\text { fashion on the project to reduce the risk of system } \\
\text { verification failing? }\end{array}$ & & & & \\
\hline \multirow[t]{2}{*}{$3.6-1.3$} & Are system verification activities planned for the project? & & & & \\
\hline & Number of questions in level one $=3$ & & & & \\
\hline $3.6-2.1$ & $\begin{array}{l}\text { Is there a written policy (may be part of a broad-based } \\
\text { policy) requiring management of system verification } \\
\text { activities? }\end{array}$ & & & & \\
\hline $3.6-2.2$ & $\begin{array}{l}\text { Is there an approved system verification plan (may be part of } \\
\text { a larger technical management plan) for the project? }\end{array}$ & & & & \\
\hline $3.6-2.3$ & $\begin{array}{l}\text { Is there a designated technical manager or team leader } \\
\text { responsible for coordinating verification activities on the } \\
\text { project? }\end{array}$ & & & & \\
\hline $3.6-2.4$ & $\begin{array}{l}\text { Is the adequacy of resources (e.g., funding, staff, tools, etc.) } \\
\text { provided for performing system verification activities } \\
\text { assessed? }\end{array}$ & & & & \\
\hline $3.6-2.5$ & $\begin{array}{l}\text { Are new and/or unproven (i.e., highest risk) designs tested at } \\
\text { the lowest assembly level to verify their compliance with } \\
\text { established requirements early in the development life cycle? }\end{array}$ & & & & \\
\hline 3.6-2.6* & Are verification results documented and retrievable? & & & & \\
\hline $3.6-2.7$ & $\begin{array}{l}\text { When skills are inadequate, is training provided to } \\
\text { engineering personnel involved in system verification? }\end{array}$ & & & & \\
\hline $3.6-2.8$ & $\begin{array}{l}\text { Are developmental (e.g., design, } R \& D \text {, etc.) verification } \\
\text { activities conducted in a structured manner to reduce the risk } \\
\text { of not passing system verification? }\end{array}$ & & & & \\
\hline $3.6-2.9$ & $\begin{array}{l}\text { Is system verification accomplished on the project in a } \\
\text { structured manner? }\end{array}$ & & & & \\
\hline $3.6-2.10$ & $\begin{array}{l}\text { Are system verification activities statused for conformance } \\
\text { to plans? }\end{array}$ & & & & \\
\hline \multirow[t]{2}{*}{$3.6-2.11$} & $\begin{array}{l}\text { Are corrective actions initiated when system verification } \\
\text { activities deviate significantly from the plan? }\end{array}$ & & & & \\
\hline & Number of questions in level two $=11$ & & & & \\
\hline $3.6-3.1$ & $\begin{array}{l}\text { Are system verification activities planned, approved, and } \\
\text { established according to a formal procedure? }\end{array}$ & & & & \\
\hline
\end{tabular}




\begin{tabular}{|c|c|c|c|c|c|}
\hline Number & Question & $\mathbf{Y}$ & $\mathbf{N}$ & DN & NA \\
\hline $3.6-3.2$ & $\begin{array}{l}\text { Are verification activities included in the early design stages } \\
\text { of the project to reduce risk of failing system verification? }\end{array}$ & & & & \\
\hline $3.6-3.3$ & $\begin{array}{l}\text { Are system verification issues (e.g., design deficiencies, } \\
\text { interface problems) included as an integral part of all formal, } \\
\text { system-level design reviews? }\end{array}$ & & & & \\
\hline $3.6-3.4$ & $\begin{array}{l}\text { Are system verification issues factored into risk } \\
\text { management? }\end{array}$ & & & & \\
\hline $3.6-3.5$ & $\begin{array}{l}\text { Are system verification processes standardized across the } \\
\text { organization? }\end{array}$ & & & & \\
\hline \multirow[t]{2}{*}{$3.6-3.6$} & $\begin{array}{l}\text { Are guidelines provided to allow the project to tailor the } \\
\text { standard system verification process for its specific needs? }\end{array}$ & & & & \\
\hline & Number of questions in level three $=6$ & & & & \\
\hline
\end{tabular}

\subsection{System Validation}

This subject area is applicable to all participants.

System validation is an "end-to-end" approach to ensure that the completed, integrated system will operate as required in the environment for which it is intended. Validation issues can be discovered early in the development life cycle through the use of early validation activities. Early validation activities use approaches similar to verification (i.e., test, analysis, simulation, etc.) to determine how the system as a whole, is likely to perform under anticipated operational and environmental conditions. Prototyping techniques may also be used.

Final system validation can be accomplished only by using the actual system in its intended environment. Validation issues are typically concerned with unanticipated or unintended behavior.

General characteristics of system validation are as follows.

- System validation is planned.

- Actual performance of the system satisfies the operational requirements.

- The system is able to perform in its intended environment.

- System requirements as specified will result in a system that satisfies the intended need.

- Validation activities (including early validation) within the project are performed in a consistent and coordinated manner. 


\begin{tabular}{|c|c|c|c|c|c|}
\hline Number & Question & $\mathbf{Y}$ & $\mathbf{N}$ & DN & NA \\
\hline $3.7-1.1$ & $\begin{array}{l}\text { Is system validation accomplished in at least an informal } \\
\text { manner? }\end{array}$ & & & & \\
\hline $3.7-1.2$ & $\begin{array}{l}\text { Is early validation conducted in some fashion on the project } \\
\text { to reduce the risk of failing system validation? }\end{array}$ & & & & \\
\hline \multirow[t]{2}{*}{$3.7-1.3$} & Are system validation activities planned for the project? & & & & \\
\hline & Number of questions in level one $=3$ & & & & \\
\hline $3.7-2.1$ & $\begin{array}{l}\text { Is there a written policy (may be part of a broad-based } \\
\text { policy) requiring management of system validation } \\
\text { activities? }\end{array}$ & & & & \\
\hline $3.7-2.2$ & $\begin{array}{l}\text { Is there an approved system validation plan (may be part of a } \\
\text { larger technical management plan) on the project to evaluate } \\
\text { related subsystems for their contribution to intended system } \\
\text { operation? }\end{array}$ & & & & \\
\hline $3.7-2.3$ & $\begin{array}{l}\text { Is there a designated engineering manager or team leader } \\
\text { responsible for coordinating validation activities on the } \\
\text { project? }\end{array}$ & & & & \\
\hline 3.7-2.4 & $\begin{array}{l}\text { Is the adequacy of resources (e.g., funding, staff, tools, etc.) } \\
\text { provided for performing system validation activities } \\
\text { assessed? }\end{array}$ & & & & \\
\hline $3.7-2.5$ & $\begin{array}{l}\text { When skills are inadequate, is training provided to } \\
\text { engineering personnel involved in system validation? }\end{array}$ & & & & \\
\hline $3.7-2.6$ & $\begin{array}{l}\text { Are early validation activities conducted in a structured } \\
\text { manner to reduce the risk of not specifying valid } \\
\text { requirements? }\end{array}$ & & & & \\
\hline $3.7-2.7$ & $\begin{array}{l}\text { Is system validation accomplished on the project in a } \\
\text { structured manner? }\end{array}$ & & & & \\
\hline $3.7-2.8$ & $\begin{array}{l}\text { Are system validation activities statused for conformance to } \\
\text { plans? }\end{array}$ & & & & \\
\hline \multirow[t]{2}{*}{$3.7-2.9$} & $\begin{array}{l}\text { Are corrective actions initiated when system validation } \\
\text { activities deviate significantly from the plan? }\end{array}$ & & & & \\
\hline & Number of questions in level two $=9$ & & & & \\
\hline $3.7-3.1$ & $\begin{array}{l}\text { Are system validation activities planned, approved, and } \\
\text { established according to a formal procedure? }\end{array}$ & & & & \\
\hline $3.7-3.2$ & Are system validation issues factored into risk management? & & & & \\
\hline $3.7-3.3$ & $\begin{array}{l}\text { Are system validation processes standardized across the } \\
\text { organization? }\end{array}$ & & & & \\
\hline
\end{tabular}


Hevin, 0

\begin{tabular}{|l|l|l|l|l|l|}
\hline Number & Question & Y & N & DN & NA \\
\hline $3.7-3.4$ & $\begin{array}{l}\text { Are guidelines provided to allow the project to tailor the } \\
\text { standard system validation process for its specific needs? }\end{array}$ & & & & \\
\hline & Number of questions in level three = 4 & & & \\
\hline
\end{tabular}

END OF QUESTIONNAIRE THANKS FOR YOUR PARTICIPATION 
RPP-4773, Rev. 0

APPENDIX E

PROJECT HANFORD MANAGMENT CONTRACT HANDI 2000 MODULE DESCRIPTIONS 
RPP-4773, Rev. 0

This page intentionally left blank.

E-ii 
RPP-4773, Rev. 0

\section{APPENDIX E}

\section{HANDI 2000 MODULE DESCRIPTIONS}

The following information provides a summary of vendor products available. Some of the modules listed were implemented into production during the Business Management Systems phase of the HANDI 2000 project. Refer to Figure 2-1 of this document for a graphic depiction of the entire system.

\section{PASSPORT $^{\mathbf{1}}$ PURCHASING MODULE}

The PassPort ${ }^{\mathrm{TM}}$ Purchasing module is an integrated set of business applications designed to control all phases of enterprise-wide Purchasing activity to support managing the full supply cycle, including direct purchase requirements and inventory replenishment. The module is architected to using advanced communications networks, cooperative processing, Electronic Data Interchange (EDI) interfaces, Evaluated Receipt Settlement (ERS), and image processing. It proactively informs buyers, material analysts, procurement engineers, requesting work crew personnel, and management by providing complete information and direct access to requisition, quotation, vendor, purchase order, and contract data. The module is also fully integrated with other PassPort ${ }^{\mathrm{TM}}$ modules, including Inventory Management, Accounts Payable, Work Management, Contract Management, Procurement Engineering, Action Tracking, Document Management, Material Safety Data Sheets, and Financials.

\section{- Catalog Data}

The data structures within PassPort ${ }^{\mathrm{TM}}$ Purchasing and Inventory Management provide immediate access to all resources and information required by the materials staff. The Master Materials Catalog is the repository of data about individual material, providing technical classification, storage requirements, purchasing parameters, current quantity availability, and material reservation summaries. Standards and procedures contain a library of instructions available to the procurement engineers and material analysts. These common clauses can be assigned as Special Instructions to each catalog record.

\section{- Vendor Data}

The Vendor Data family is a repository of all vendor-related information, including addresses, performance ratings, classification and qualification for quantity-related purchases, purchase default parameters, and EDI capabilities. The panels also provide the ability to search for vendors in various ways, including full-text search over vendor name, by products supplied, by location, and by quality status.

\footnotetext{
${ }^{1}$ Passport is a trademark of Indus International, Inc., San Francisco, California.
} 


\section{- Pre-Award}

Request for Quote (RFQ) can be constructed for multiple items and sent to multiple vendors, with specific requirements brought forward reflecting the catalog requirement definition and vendor-specific quality data. The quotation database built from the vendor responses is used in determining which vendor to recommend during the Purchase Order award. Vendor Bids may also be scanned into the system through ViewPort. Spreadsheet capabilities provide the RFQ analyst with a detailed breakdown and comparison of each vendor's response to and RFQ.

\section{- Requisition Processing}

The requisition process initiates the purchasing cycle for all maintenance, warehouse, and corporate needs. This integrated process is the link between Purchasing and the inventory and warehouse replenishment functions. Purchase requisitions are created to satisfy current and forecasted requirements driven by the demand from material requests, work orders, inventory, and general purchase needs. Once a requisition has been created, it is electronically routed for approval and sent to the designated buyer for incorporation into and RFQ or purchase order. By tracking the status through the purchasing lifecycle and through management of requisition backlogs, critical delivery requirements can be met while approved procurement practices are maintained.

\section{- Purchase Order Processing}

Upon requisition approval, catalog items, which are defined as "Auto-Award," will have a purchase order automatically created and approved. Items defined to Blanket Orders are automatically assigned to the next release. All other items are electronically assigned to a buyer's in-box for computer-assisted award processing. Buyers select requisitions to be awarded, and PassPort ${ }^{\mathrm{TM}}$ presents all bid and historical purchase information to facilitate selection of the best vendor. When a vendor is selected, the Purchase Order and Line Item are automatically built based on information in the system. Once a purchase order has been created, it can be modified or can be immediately routed for electronic approval and sent to the designated vendor. Expediters can be assigned to monitor the purchase order through delivery and receipt.

\section{- Contract Administration}

Contract Administration capabilities are provided to accommodate all types of Contract Agreements and Service Order purchases. To help establish a scope of work and meaningful controls for tracking contracted services, access to a set of panels in PassPort ${ }^{\mathrm{TM}}$ Contract Management module are available. The Contract Scope of Work and Amendment Scope text is enabled by object linking and embedding (OLE) to take full advantage of work processing features, including multiple fonts, bolding, italics, and strike-through capabilities. Contract boilerplate text is easily copied into the contract being developed. Milestones can be defined and tracked for the contract, with alert messages being automatically sent to the user at predetermined milestone dates. 
RPP-4773, Rev. 0

\section{- Management Reporting and Audit}

Management reporting is available at both summary and detailed levels, presenting online history of purchase activity and real-time summarization of purchases by period. These decision support tools include an unlimited array of views of the information including views of purchase orders by vendor, buyer, value, award basis, facility, and other strategic qualifiers. Through use of these on-line reports, PassPort ${ }^{\mathrm{TM}}$ enables management to quickly analyze and evaluate purchasing practices and trends. PassBook audit details provide information about commitments to purchase materials, outside services, and all inventory transactions that affect the financial ledgers.

\section{PASSPORTTM $^{T M}$ CONTRACT MANAGEMENT MODULE}

The PassPort ${ }^{\mathrm{TM}}$ Contract Management module has been designed to handle various types of contracts, allowing contract analysts to manage and monitor the entire life cycle of contracts, from initiation of the request through contract closure.

- Data

The Standards and Procedures Library contains predefined variable documents for attachments as Terms and Conditions. Vendor information includes name, status, address, default terms, capabilities, and contracts. Work-related information such as phone numbers can be defined for relevant internal personnel and contractors. Contract ID shows contractor assignments. PassBook provides a view of the committed and estimated actual values generated by Contract Management.

\section{- Contract Requisition}

Contract Requisition provides the users with the ability to request the setup of a new contract or request the release of work against an existing contract by entering a contract requisition. This allows the initiator to define as much information as possible before passing the request on to the Contract procurement group. Routing and approval is provided, and the appropriate individuals are notified of actions required. The Contract Requisition Backlog provides the procurement group with an effortless method of balancing existing workload, viewing expected contract requirements, and awarding contracts.

\section{- Request For Proposal Activities}

A Request for Proposal (RFP) can be optionally generated from a contract requisition, and sent out to multiple vendors to solicit tender bids for the services defined in the request. Vendor Proposal Bids are recorded against the RFP and can be linked to spreadsheet analysis to aid the contract analyst in selecting the best vendor. The winning proposal provides a template for the resulting contract. 


\section{- Contract Award And Monitoring}

The system is designed to handle various types of contracts, including both large general scope of work contracts as well as contracts with detailed rate structures defined. Personal computer-based word processing facilitates definition of the detailed scope of work and terms and conditions. Rate structures for labor hours or other non-labor rates and charges (e.g., rentals of equipment, cost per foot of work performed) are supported. This provides validation for the Labor Entry and Reporting and helps establish estimates and 'not to exceed' levels. Contract Releases control the approved work against Blanket Master Contracts. Revisions to approved contracts are supported through Contract Amendment processing. Authorized individuals can create, approve, and track individual changes in scope, schedule, rates, and value.

\section{- Payment Authorization}

As work is completed, Payment Authorizations record the work performed. These serve as preapprovals for invoice matching. Automated itemization and value of time sheets recorded against the Contract through Labor and Reporting are provided. Invoices entered by Accounts Payable are matched to the contract and its payment authorizations. If the invoice has been preapproved, no further action is required by the Contract Team. If the invoice exceeds authorized amounts, the invoice is mismatched and an Action/Awareness/Alert (AAA) message is sent to the Contract Invoice Approver.

\section{- Management Reporting}

Contract costs can be viewed in chronological order in a columnar display and provide a comparison of committed, estimated actual and invoiced actual values. High-level management views are provided by showing various views of contract totals. Drill-down capabilities are available to view details as desired. The invoices recorded by Accounts Payable are listed for each contract, along with the invoice value and status of each. Direct navigation provides unlimited access to invoice information.

\section{PASSPORT $^{\text {TM }}$ INVENTORY MANAGEMENT MODULE}

The PassPort ${ }^{\mathrm{TM}}$ Inventory Management module is an integrated application designed to control all phases of inventory control and warehouse management. It actively manages all phases of inventory control, warehousing, and material replenishment requirements. This on-line, realtime system provides material analysts, warehousing, and procurement and material users direct access to precise material identification and pending activity requirements.

\section{- Cataloging}

Catalog Templates are used to establish standard structured descriptions for the Catalog Items. The Master Parts Catalog is the repository for data about individual material, providing technical classification, storage requirements, order parameters, current quantity availability, and work order reservation summaries. Standards and Procedures contain a library of instructions available to the procurement engineers and material 
analysts. These common clauses can be assigned as Special Instructions to each catalog record.

\section{- Inventory Set-Up And Audit}

The data modules are central repositories that reflect the actions taken by the Roadmap activities. Location data are used with the Catalog Warehouse Location to provide computer-assisted putaway recommendations. Material labeling information for locations and existing material is provided. Uniquely Tracked Commodity panels contain logged entries of individual parts that are tracked by serial, heat, batch, or lot numbers. PassBook is an audit trail. All cost-related material movement is collected to provide an audit trail of activity for the Catalog ID. The PassBook audit information serves as the central vehicle for handling interfaces to other systems.

\section{- Material Request}

The material request supports the request of stocked, direct charge, consignment, and non-cataloged material. A material request can be created as a stand-alone request or can be referenced to a work order, design change, outage, etc. Approval of a material request automatically will allocate available material to the request and begin the replenishment process if requested material is not available. The material request panel is directly accessible via the Work Management System's work order family to allow creation of material request(s) along with the work order task. Approval routing, model, and background capabilities are available. Picks can also be automatically generated.

\section{- Receiving}

A three-step receiving capability is provided so that material can be tracked from its initial arrival on the dock to the detail stores inspection and, where required, to the Quality Control (QC) inspection process. Receipts are logged at the purchase order level, then individually inspected for general material conditions. Items requiring immediate action (e.g., a part of a critical work order or material request) are highlighted as 'hot' items so they can be expedited quickly through receiving to issue process. The received quantity is recorded with its disposition (i.e., accepted, rejected, stores, hold, or route) for QC inspection. Parts can be tracked to serial number, lot, batch, or heat number to provide traceability of parts to work orders. Bar-coded material tags are produced, as well as Material Receiving Reports. Over, short, damaged and discrepancy reporting is provided. Material can be sent to the issue counter or distributed to the warehouse where it is to be stored.

\section{- Quality Control Receiving}

The QC panels provide the vehicle for the QC inspector to monitor material receipts or returned parts against a pre-established QC plan. The QC plan is established on the master parts catalog. It uses system-wide standards and procedures to define inspection and testing requirements for individual catalog items. These consistent plans serve as the basis for the QC inspection activity. 


\section{- Warehouse Distribution}

Warehouse Distribution function tracks material as it is moved from one warehouse to another warehouse within a facility. This function is used to segregate material into an emergency warehouse. Emergency material is not available for the normal workflow.

\section{- Putaway}

These panels are used along with the warehouse location data to determine the 'best' putaway location for the part. The system recommends possible putaway locations using a variety of information that is know about the material, including storage equipment requirements, potential usage as established by the $A B C$ codes, and storage level requirements. An option exists to use hand-held portable data terminals to report the actual putaway disposition on the warehouse floor and eventually uploading of the data into PassPort ${ }^{\mathrm{TM}}$ for updating of the parts catalog.

- Picking And Staging

Pick Lists can be generated based on planned and scheduled work order and material request parts requirements. Resource-leveling features are available to plan and schedule the picking activities. On-demand pick requests can be generated and routed to the warehouse, or they can be created and generated at the issue window. Search features help identify the needed material. Parts can be pre-staged or sent to the issue window for direct issue to a material request. Hand-held portable terminals can be used to gather and upload the picked data.

\section{- Issue And Return}

To reflect reality on the warehouse floor during emergency maintenance conditions and other special circumstances, unplanned material requirements are accommodated with these panels. Direct checkout and return of the parts is provided. Tool issues are also supported, and recalibration requirements are monitored. The system has the capability to deliver material as specified on the material request.

\section{- Shipping}

The Shipping panels provide a means of processing shipments to external vendors or customers for disposal and sale or outside services. Outside services for repairs, testing, recalibration, etc., are accompanied by a purchase order for the service. The return of the material being serviced is handled through the receiving functions. Packing slips, shipping labels, and bills of lading also can be produced to schedule and track internal issues and facility transfers.

\section{- Replenishment}

These functions are used to analyze current and forecasted requirements for a particular Catalog ID. They provide usage information and an examination of material requests for future replenishments. The statistics are used to analyze replenishment needs and 
recommended stocking levels. When replenishment requests are submitted, the materials analyst evaluates the needs and available material at other sites. They may elect to request that material be transferred from the other sites rather than process new orders.

\section{- Facility Transfers}

Material transfer requests (pick requests) can be generated automatically if restocking arrangements are pre-established, so that material can be transferred between facilities to provide cost-effective utilization of material. An on-demand pick also can be generated from the requesting facility to the Transfer From Facility. Pick Requests for Transfers follow the normal pick workflow. Transferred material is received using the normal receiving panels.

\section{- Stock Verification}

Stock verification panels provide the capability to schedule cycle counts and monitor progress on the cycle count activities. The system provides a logical path through the warehouse to accomplish the required counts. Variances are monitored and reported online. These variances can be approved or scheduled for recounts. Hand-held portable data terminals can be used to perform the cycle counts and upload data.

- Material Maintenance

The Work Management panels are used to plan and schedule any maintenance work required in the warehouse including maintenance of materials. Recalibrations and InStore maintenance can be set up using the Predefine Parameters to generate recurring work orders.

- Maintenance-Related Data

The Inventory Management module uses several data modules that are shared with other PassPort ${ }^{\mathrm{TM}}$ systems to provide cross-application information about the plant configuration and personnel.

\section{- Warehouse Management Decision Support Tools}

Decision support tools are provided that analyze logically the data captured by PassPort ${ }^{\mathrm{TM}}$. On-line panels and reports analyze vendor lead times, determine ABC codes, identify stock usage, etc. The system provides a feature to do a break-even analysis to determine if parts should be surplused. The tools are provided to logically organize the warehouse for best space utilization and, hence, better productivity of your valuable resources. The Warehouse Wizard provides graphic representations of the data to assist with evaluations of warehouse location use. 


\section{- Catalog Analysis}

Catalog Templates is a powerful tool used to effectively utilize the current inventory. The use of templates result in the user community being able to find their needed parts more easily and efficiently and provide a better means of consolidating purchases, resulting in cost savings.

\section{- Order Parameter Analysis}

The key to better inventory control is the reduction of inventory costs while maintaining the service levels to the user community. These analysis tools assist management in determine problem areas for inventory value increases, as well as making progress in reducing inventory value. The Stock-Out Analysis panels allow the users to evaluate their stock-outs and actual service levels against their target service levels. The Turnover ratio tends to measure the liquidity of the inventory. Up to a point, high turnover ratios are a positive sign that the inventory is being moved quickly, as long as high turnovers do not jeopardize the service levels and increase the number of stock-outs.

\section{- Usage History And Forecasting}

The Usage and Forecasting Analysis panels provide an evaluation of your current usage and usage projections. Effective use of the Usage Analysis and Forecasting tools will ensure that material is available when needed. The stock models provide analysis for parts that have consistent usage and are subject to the classical reorder point and target maximum calculations to maintain the inventory levels. The forecasting panels provide analysis of exceptional use such as seasonal and outage-type items that normally are not planned in advance. These tools provide the reliable availability of parts while maintaining the inventory value at a reasonable and cost-effective level.

\section{PASSPORT $^{\mathrm{TM}}$ ACCOUNTS PAYABLE MODULE}

The PassPort ${ }^{\mathrm{TM}}$ Accounts Payable module is an integrated set of computer-based processes designed to support the full spectrum of invoice entry, transaction matching, cash disbursements, and reconciliation functions. This primarily is an on-line system that takes advantage of relational database capabilities. Batch processing and reports are added where user requirements and procedures dictate the need. There are standard batch processes to accept information from and provide information to outside applications.

\section{- Payment Entry}

Payment Entry provides the ability to enter payment requests. Invoices are related to material items, and details may be background from the related Purchase Order Contract. Vouchers are payments to a vendor for a single item such as a mortgage payment or utility bill. Accounting that identifies the expenses or advance information supports employee payment. Information common to one or more types of payments is addressed through the Shared Payment Detail panels. 


\section{- Payment Summary}

Payment Summary provides a list of payment requests that meet user-specified criteria. Accounts Payable processors can view a wide range of invoice/payment information on a single panel to quickly address vendor inquiries. Payments may be placed on Hold or released from Hold via selection on the summary panel. If an Immediate Payment is to be made or a manual check has already been prepared, the panel provides a means to record this activity and bypass the Accounts Payable Payment processing for the associated payment requests (Invoice, Voucher, Employee Payment).

\section{- Cash Requirements}

This set of panels provides the ability to view the cash requirements from an annual, monthly, daily, and daily detail perspective. Although the panels may be entered directly, they serve as a drill-down of funding needs. The by-month and by-day panels have options that allow the inclusion of Paid, Partial, Hold, and Mismatch payments in addition to the normal Approved payments. The purpose of these panels is to provide visibility of past, current, and future funding needs based on the Invoice, Voucher, and Employee Payment requests. The Open and Held Payment Summaries look at payments that are in process.

\section{- Check Summary}

The Check Summary panels provide lists of checks based on Remit Vendor, Employee, Bank ID, Bank Account, and Purchase Order Number. Additionally, a Date Range and Check Status may be specified to restrict the lists. Basic information is provided for each check. If additional information for a specific check is requested, then the user is taken to the Check Details Panel. These panels are a starting point when researching a payment that has been made already.

\section{- Bank Reconciliation}

Bank Reconciliation is the final step of the processing of a Payment Request. It is here that the payments made are reconciled with the payments cleared through the financial institutions. The bank account adjustments including Deposits, Service Charges, and Interest Earned are entered via the supporting panels. The Account Reconciliation panel has a summary of the reconciliation status comparing the reconciled items to the bank statement. The Deposit and Withdrawal panels provide for the entry of additional items along with their corresponding accounting. Descriptions are available if a notation of the reason for the deposit or withdrawal is needed.

\section{- Matching}

The matching panels provide three views of the payments request that have conditions that are outside user-specified acceptance tolerances. The backlog panel lists all payments requested that have been sent to the selected alert group or analyst, or within the specified amount or date range. If there is an invoice-level mismatch, a line-level mismatch, or both, they will appear on the backlog panel. The Invoice Match Error panel 
presents a comparison between the purchase order totals and the invoice totals and indicates if there is a tax, freight, or overall mismatch. The Line/Subline Match Error panel presents the comparison values from the purchase order line, invoice line, receipts, and QC checks, and indicates if there is an order, unit price, line total, receipt, or QC mismatch. The Authorizations and Invoices panel presents a comparison of contract authorization totals and invoice totals. Authorized users may override three match error panels.

- Shared Payment

Shared Payment provides additional information for one or more types of payment requests (Invoice, Voucher, and Employee Payment). Model invoices may be set up to be paid automatically on a recurring basis. A summary of invoices generated from a given model is presented on the Recurring Payment Summary panel. Invoice and Voucher accounting is required before the payment is accepted. The routing instructions, payment comments, and a list of checks issued against a specific payment request are presented on the Payment Details panel. The remittance advice information for a check and its reconciliation status are shown on the Check Details panel. A narrative audit of payment processing at the header, line, and subline levels is presented on the Payment Audit panel along with the user, date, and time of the payment action.

- Electronic Data Interchange

If a payment request is received via EDI, the client first translates it to a flat file. The Accounts Payable EDI processing then reads this file to create invoices that may be reviewed and updated on-line. If data errors occur, EDI records are stored in temporary data tables that may be viewed on-line. The data errors also may be corrected on-line and resubmitted to the EDI process.

- System Administration

In addition to the use of the standard PassPort ${ }^{\mathrm{TM}}$ code validation tables, there are several Accounts Payable unique values that must be established before payment requests can be entered. This is accomplished through the use of the Systems Administration Panels.

\section{PASSPORT $^{\text {TM }}$ DOCUMENT MANAGEMENT MODULE}

The Document Management system consists of two interrelated products: Controlled Documents and Records Management; and a supporting function, Controlled Distribution. Controlled Documents provides the capability to index information about controlled documents, crossreference them with other documents, and control the process of revising them. Records Management provides the capability to index archival documents for later retrieval. Controlled Distribution provides the capability to control the distribution of documents, track their transmittal, and monitor receipt acknowledgement. 


\section{- Controlled Documents}

Controlled Documents provides the capability to index information about controlled documents, cross-reference them with other documents, and control the process of revising them.

\section{- Document Revision Activities}

Document Revision activities include revision tracking and historical information about previous revisions as well as acknowledgment receipt tracking and distribution history information. Image mark-up and text editing with routing for approval are also available. References are provided on microfilm, hardcopy file locations, and image addresses; and a document check-out/check-in function can be used.

\section{- Records Management}

Records Information activities provide integration with the Controlled Documents module, identification of records retention requirements per document type, consistent indexing and retrieval of vital documents. Document-to-document cross-reference capabilities are available as well as cross references between documents and other PassPort ${ }^{\mathrm{TM}}$ functions such as equipment/components and parts. Records can be indexed to microfilm or hardcopy locations.

\section{- Records System Administration Activities}

The types of documents to be indexed in the Records Management module are defined on the Required Records List.

\section{- System Administration Activities}

Document Type and Subtype codes are maintained here. Multiple subtypes may be defined for a single document type, and security events may be associated with a document type.

\section{PASSPORT'M ENGINEERING CHANGE CONTROL MODULE}

The Engineering Change Control system provides design change tracking using VIEWPORT, Image Routing, and PassPort ${ }^{\mathrm{TM}}$ AAA Notification feature.

\section{- Design Change Package Tracking}

Design Change Package (DCP) activities identify and track a DCP record, which contains groups of related Design Change Notices (DCNs). DCP tracking records are used to identify the design change, track approvals that take place at the package level (e.g., plant approval), and list and monitor the current status of associated DCNs. 


\section{- Design Change Notice Tracking}

DCN activities identify and track DCNs from creation to completion. Within the DCN tracking capabilities, status tracking informs users of the exact status of the DCN at any point in time. It is possible to enter references to initiating documents, related documents, and related PassPort ${ }^{\mathrm{TM}}$ records.

\section{- Field Change Activities}

Field Change $(\mathrm{FC})$ records are created to identify and track FCs from initiation to completion. Within the FC capabilities, status tracking informs users of the exact status of the FC at any point in time. The DCN and FC modules are linked to ensure that actions taken in either module are appropriate based on DCN status and the status of associated FCs. It is possible to enter references to initiating documents, related documents, and related PassPort ${ }^{\mathrm{TM}}$ records. Affected documents are listed, and both the record for the affected document and the associated DCN record are notified automatically of the FC. Image folders for affected documents can be created using Viewport. The images can be used for annotation of changes. Annotated images of proposed changes can be routed for review and approval.

\section{- Document Correction Requests}

Documentation Correction Request activities are provided to track documentation-only changes or corrections.

\section{PASSPORT $^{\text {TM }}$ LABOR ENTRY MODULE}

The PassPort ${ }^{\mathrm{TM}}$ Labor Entry and Reporting system has been designed to allow the ease and accuracy of time capturing and labor reporting. These basic fundamentals are the building principles that support timely and accurate payroll and estimated actual labor costs while reducing reconciliation efforts.

\section{- Time Entry}

Time entry requirements are multi-dimensional. Thus, the time entry feature of the PassPort ${ }^{\mathrm{TM}}$ Labor Entry and Reporting system supports a wide variety of mechanisms by which time sheets are created, by which personnel define the wage type and any additional premiums to be paid over and above the base pay.

\section{- Time Sheets}

Recorded crew hours against PassPort ${ }^{\mathrm{TM}}$ Work Management work order tasks automatically create time sheets with the correct charge codes, labor hours, and service type. Time Sheet Models or Templates and Time Sheet Backgrounding facilitate the creation of consistent time sheets from pay period to pay period. At the point of entry, definition of service types is required, thereby assisting in the establishment of estimated 
RPP-4773, Rev. 0

labor costs. A special feature of the PassPort ${ }^{\mathrm{TM}}$ Labor Entry and Reporting System is its flexibility in supporting Direct and Contract Personnel.

System integration between Labor Entry and the PassPort ${ }^{\mathrm{TM}}$ Contract Management system provides detail time capture for Payment Authorization reconciliation against contractor invoices. Labor recording accuracy is ensured through real-time interfaces with the PassPort ${ }^{\mathrm{TM}}$ Work Management, Action Tracking, Engineering Change Control, Project Management, Financial Management, and Contract Management systems. Although the PassPort ${ }^{\mathrm{TM}}$ Labor Entry and Reporting system takes advantage of these PassPort ${ }^{\mathrm{TM}}$ applications, they do not limit it. Labor Entry enables non-PassPort ${ }^{\mathrm{TM}}$ object time capturing and reporting as well. Once a time sheet is created, it can be revised or approved; then the appropriate time charges can be forwarded for posting to an external Payroll System in a 'passive' mode. Labor recording accuracy is also ensured through a full-cycle revision and approval process. Approvers are user defined; therefore, they are open to varying organizational structures. Time sheet accuracy and completion is provided at an additional level supported by the Time Reporting Group.

- Labor Entry and Reporting System

With the PassPort ${ }^{\mathrm{TM}}$ Labor Entry and Reporting system, full audit trail capabilities capture all time sheet modifications. Time Sheet delinquent tracking capabilities are available on-line or through hardcopy reports. File management functions are provided through the Time Sheet Archival Process. At any given stage in its life cycle, revisions can be made to the time sheet, basically until it has been archived. If labor hours have already been posted to an external Corporate Payroll System, the Labor Adjustment feature is available to send needed correction transactions.

\section{PASSPORT ${ }^{T M}$ PROJECT MANAGEMENT MODULE}

The PassPort ${ }^{\mathrm{TM}}$ Project Management System is designed to provide project personnel with the information necessary to effectively control projects throughout the project life cycle. Project Management is a comprehensive on-line information management system supporting the definition, planning, approving, monitoring, and closing of expense as well as capital projects. The system recognizes and supports the requirement to maintain project cost and work information in one integrated system, providing timely and useful analysis and decision support functionality.

Project Management is fully integrated with other PassPort ${ }^{\mathrm{TM}}$ systems including Inventory Management, Accounts Payable, Purchasing, Work Management, Contract Management, Document Management, Financial Management, and Labor Entry. 


\section{- Project Initiation}

Defining a project is the start of the Project Management process. A project may be entered directly into the system or may be initiated from an Action Request. All phases of a project are tracked during the project life cycle - Project Initiation, Planning, Approval Routing, Monitoring, Analysis, and Completion.

During Project Initiation, information about the project is recorded. A project hierarchy may be established for complex projects to assist in organizing and managing the project. For short, straightforward projects, data can be entered with a minimal number of keystrokes and panels. Studies are supported as an initial project phase to ensure that all work and costs are tracked for a project from inception to completion.

\section{- Project Planning}

The Planning phase includes support for estimate/budget development as well as work planning. Multiple revisions of both work schedules and budgets are supported as the project progresses. Multiple calendars can be defined by an organization to support varied views of project budget and cost data depending on business needs. Calendars are like a time template that defines the date ranges to be grouped together. They allow the same data to be viewed in days, weeks, months, years; or any other date range at different points in time.

\section{- Project Approval}

An Approval Package is provided to support approval requests for project budgets and work schedules. PassPort ${ }^{\mathrm{TM}}$ electronic Approval Routing function supports the approval process. Upon approval, the Original Approved and Current Approved versions of the budget and work schedule are protected automatically.

Once a project is approved, funds can be authorized for expenditure by requesting approval of an Authorized Amount. Authorizations can be changed throughout the project life. An Available to Spend amount is calculated by subtracting all outstanding commitments, estimated actuals, and actuals from the authorized amount.

\section{- Project Monitoring}

As a project progresses, Forecasts can be created and updated to assist in project monitoring and control. Forecasts are a combination of the actuals charged to a project through a point in time and the estimate-to-complete the project. Actual charges are obtained through integration with Accounts Payable and any non- PassPort ${ }^{\mathrm{TM}}$ products such as a Payroll system. The estimate-to-complete is based on an existing Budget or previous Forecast. The estimate-to-complete portion of the Forecast can be adjusted, as needed, to reflect the latest information. 
If the work is complex, subprojects may have been defined. The current Forecast for each subproject can be accumulated with all the other subproject's Forecasts to create a Current Rollup Forecast for the entire project at the Parent Project level of the project hierarchy.

Project Management is integrated with PassPort ${ }^{\mathrm{TM}}$ Work System products to facilitate initiation of Action Requests, Work Orders Material Requests, Time Sheets and Contracts from Project Management. Each of these work objects also can be associated with a project when it is created.

\section{- Project Analysis}

Comparison and variance information is provided to assist in project management, analysis, and control. This information can be downloaded to Microsoft ${ }^{2}$ Excel for graphics presentation and trend analysis.

\section{- Project Completion}

When the project is completed, information related to the project is readily available for closing reports, reconciliation processes, postmortem reviews, and for capital projects during the capitalization/unitization process.

\section{PASSPORT $^{\text {TM }}$ WORK MANAGEMENT MODULE}

The PassPort ${ }^{\mathrm{TM}}$ Work Management system has been designed to allow craftsmen to access data and record essential progress so that the clerical burden is distributed and information is widely shared. Shift supervisors and team leaders can perform the supervisory role needed for craftsmen comprising a crew to use the system effectively and to help coordinate necessary daily activities. To keep such individuals informed and in control of daily work activities, PassPort ${ }^{\mathrm{TM}}$ supplies electronic messaging that actively informs users of changing conditions. These tools help managers react to unexpected conditions, prioritize work, and assist in communicating direction throughout each affected organization.

\section{- Data}

As defective equipment/components are identified, the work planner can make efficient use of equipment downtime by running a downtime optimizer process. This facility looks ahead, to near-term preventive jobs, planned outages, and other outstanding work requests, to create a work package that will complement available manpower and downtime permitted by operations. Spare equipment identification and tracking and reservations for spare parts against planned work are also available to make immediate decisions on replacement and availability. The PassPort ${ }^{\mathrm{TM}}$ Work Management system is interfaced with the PassPort ${ }^{\mathrm{TM}}$ Inventory Management system to provide access to catalog information, parts reservation, parts reorder, and special order functions.

\footnotetext{
${ }^{2}$ Microsoft is a trademark of the Microsoft Corporation, Redmond, Washington.
} 


\section{- Work Scheduling and Completion}

Maintenance department staff often finds itself attending to problems that arise suddenly and for which there are no prescribed remedies or written instructions. Even with competent maintenance planning, the scope of such tasks reflects "best guess" requirements and may be refined only after hands-on tear-down activities begin. Scope changes requiring additional parts, special tools, and labor to complete the task are not uncommon activities. The scheduling components within the PassPort ${ }^{\mathrm{TM}}$ Work Management system have been designed to consider this real-world scenario. Unplanned or emergency work, which does not enter the backlog, is reflected on the daily schedules as work, that has consumed available resources. For pre-planned tasks, the PassPort ${ }^{\mathrm{TM}}$ Work Management system tracks work orders in backlog and applies pre-assigned priority parameters to the scheduling programs to help provide a consistent view of work assigned and available remaining resources. By providing an electronic auto-scheduler, near-term work is scheduled in order of priority to the limit of available resources determined as acceptable by the planner. In this manner, items may be selected from the electronically scrolled backlog and fed to the daily activity schedule for final review.

The electronic notification system once again is extremely helpful in alerting these affected departments in order to avoid situations of conflict before parts and labor are committed. Once the schedule is frozen, crews can be assigned and complete work packages printed in the work planning centers with specific instructions for further coordination of individual craftsmen. At this time, parts and special tools also are requested electronically via pick list generation on warehouse printers allowing time for storeroom personnel to checkout and deliver parts, if requested.

PassPort ${ }^{\mathrm{TM}}$ provides maintenance supervisors and other plant and facility management personnel with on-line access to cost and experience data. This information provides a level of decision support that helps identify and avoid patterns of costly inefficiency.

Managers can control the activities of planners by reviewing requests for concurrence with operational guidelines and scheduled outage plans. The electronic routing system handles the routing and tracking of these requests throughout the work order life cycle. Management is kept informed of equipment availability and cost performance with a series of summary data panels.

\section{- Analysis}

The PassPort ${ }^{\mathrm{TM}}$ Work Management System design merges user requests with operational goals, previous solutions, and historical data to help managers and operations and maintenance personnel coordinate related tasks and make better decisions. The modular application design is geared toward building a single information resource while providing a mechanism to pass and port data to and from other automated systems in the future. 


\section{PASSPORT ${ }^{\text {TM }}$ CURATOR}

Curator is an integrated product for advanced electronic document management (EDM) and Workflow. The major components of Curator EDM, and Workflow allow the user to store and retrieve documents in many different formats, index them, and route them via folders to various other users.

- Electronic Document Management

EDM focuses on document input, registry, indexing, and integrity. Extensive security features ensure that only authorized users have access to available documents. Users can also determine which version of a document is the most current.

- Workflow

Workflow supports a history or audit on all system activities that occurred during the life of a folder (e.g., who initiated the routing, when it was initiated, and who reviewed and approved it). Workflow also notes any actions taken.

\section{- Imagenation}

Imagenation is an imaging application for engineering drawings. A user can scan, view, redline, markup, edit, and print with Imagenation.

- Full-text Search (Optional)

Curator has the ability to find all occurrences of a particular word or phrase.

\section{- PassPort ${ }^{\mathrm{TM}} /$ Curator Integration}

PassPort ${ }^{\mathrm{TM}}$ and Curator are designed to work together, allowing electronic documents to be attached to PassPort ${ }^{\mathrm{TM}}$ line-of-business objects. While in a PassPort ${ }^{\mathrm{TM}}$ window, the user can do the following: (1) view and print documents; (2) open electronic documents indexed as PassPort ${ }^{\mathrm{TM}}$ Controlled Document or Record in Curator and perform any other Curator activity; (3) view and print a PassPort ${ }^{\mathrm{TM}}$ line-of-business object folder; and (4) open a PassPort ${ }^{\mathrm{TM}}$ line-of-business object folder in Curator and attach electronic documents (e.g., scans, drawings, memos, email) or perform any other Curator activity.

\section{PeopleSoft ${ }^{3}$ HUMAN RESOURCES}

PeopleSoft ${ }^{\mathrm{TM}}$ Human Resources was designed to support multiple functions such as develop workforce, administer workforce, monitor workplace, and define business rules. Note: The develop workforce functions are not currently being used in the Business Management System Human Resource's portion.

\footnotetext{
${ }^{3}$ PeopleSoft is a trademark of PeopleSoft Inc., Pleasanton, California.
} 
- Foundation Tables

These tables provide the means to enter organizational data such as identifying the different companies within the organization and different units or locations within each company. Once this information is in the system, users across all functional areas of Human Resources can perform their daily tasks without having to enter this information manually. Tables that are affected are Company, Installation, Establishment, Location, Department, Salary Plan, Salary Grade, Salary Step, Job Code, and Pay Group.

\section{- Employee Data}

When an employee is hired, essential employee data must be added to Human Resources, including personal-, employment-, job-, and benefit-related data. Once the employee information is in the system, printed reports can be generated, summary data panels can be viewed, and ad hoc queries can be performed on-line. Employee data can also be used as a basis for performing tasks in all other aspects of human resource management, such as salary administration, regulatory requirements, payroll, and benefits.

\section{PeopleSoft ${ }^{\mathrm{TM}}$ BENEFITS MODULE}

The Benefits module comprises two parts: employee data and benefits tables. Benefits tables store information about the benefit plans offered by the company, such as types of plans, premium costs, insurance rates, and enrollment rules pertaining to the plans. Employee data specify the plans and providers chosen by an employee, coverage elected by the employee, and dependents and beneficiaries for each plan. Benefits-related payroll deductions and employer contributions are automatically generated during payroll processing once the employee is enrolled in benefits plans.

\section{- Benefits Setup}

The Benefits Setup panels consist of payroll deductions, heath plans, life insurance plans, disability plans, savings plans, leave plans, and flexible spending accounts.

\section{- Employee Data Setup}

The Employee Data Setup panels consist of enrolling the employee by assigning the employee to a benefits program and setting up the employee's dependent and beneficiary data.

\section{- Calculating Deductions}

Calculating Deductions includes four phases: setting up the tables used by programs to calculate deductions, running the programs, verifying that deductions are correct, and confirming the deduction amounts. 
RPP-4773, Rev. 0

\section{- Leave Accruals}

When the Leave Accruals Calculate program is run, leave hours taken is deducted automatically from an employee's leave balance. After the leave accrual process is run, the results can be viewed for each employee on-line.

\section{- Consolidated Omnibus Budget Reconciliation Act (COBRA)}

PeopleSoft ${ }^{\mathrm{TM}}$ COBRA panels provide the means to track who is eligible for COBRA coverage and communicate with them, calculate the cost of COBRA coverage, and maintain records of when eligibility and coverage begins and ends.

\section{PeopleSoft $^{\text {TM }}$ PAYROLL MODULE}

PeopleSoft ${ }^{\mathrm{TM}}$ Payroll is designed to provide complete control over all aspects of the payroll operation. It includes time reporting, payroll calculation, and tax computation to check preparation, payroll, and tax reporting.

\section{- Payroll Processing}

The Payroll Processing tables are the driving forces behind how earnings, deductions, and taxes are organized and calculated for each employee on the payroll docket. The primary functions of the associated panels are to define how earnings and deductions are calculated and organize how the payroll will be process.

\section{- Payroll Tax}

The Payroll Tax tables store tax information that the system requires for calculating and reporting taxes.

Tax tables provided by PeopleSoft ${ }^{\mathrm{TM}}$ are as follows:

- Federal/State Tax and Local Tax, which contain rates and other constants used in the calculation of all forms of taxes for federal, state, and local taxing entities.

- State and Local Tax Reciprocity tables, which define reciprocal taxing agreements between states and localities as well as other rules for determining tax liabilities when multiple jurisdictions are involved.

- Taxable Gross Definition Table, which identifies differences between states and/or localities and federal government in the definition of taxable wages.

- SWT Marital Status Table, which defines the valid marital status codes for each state.

Customer created/updated tax tables are as follows:

- Company State Tax and Company Local Tax tables, which store tax identification numbers, unemployment experience rates, and General Ledger (GL) codes for the states and localities for which the company collects and pays taxes. 
- Tax Reporting Parameters Table, which controls the execution of many quarterly and annual tax reports and specifies data needed for magnetic media.

\section{- Paysheets}

Paysheets must be run before Payroll calculations can be run. Paysheets serve as a repository for the raw data required to calculate employee pay for each pay period. Paysheets are used to enter time data as well as any additional payroll-related information such as earnings, on-time deductions, one-time taxes, accounting data, and tax periods and frequency.

\section{- Pay Calculation}

Pay Calculation is processed after Paysheets have been created and updated with the required changes for the pay period. The Pay Calculation program is used to process all the information setup on the PeopleSoft ${ }^{\mathrm{TM}}$ Human Resource tables and Payroll tables at the employee level, combined with the additional information provided on paysheets, to calculate payroll.

\section{- Pay Confirmation}

Pay Confirmation is run after pay calculation. During the confirmation process, the system updates all to-date totals for earnings, deductions, taxes, and arrears; the system also assigns check or advice numbers. Once the payroll has been confirmed, the checks, advices, and payroll reports are generated. In addition, direct deposit, general ledger, or any other interfaces can be generated. Employee's check totals and payroll balances can be viewed on-line.

\section{- Online Check and Off-Cycle Processing}

When employees are terminated, need additional pay, or checks need to be reversed, it maybe necessary to issue a paycheck "on the spot." Off-Cycle processing provides the means to create paychecks that need to be issued outside the normal payroll cycle.

\section{PeopleSoft ${ }^{\mathrm{TM}}$ GENERAL LEDGER MODULE}

PeopleSoft ${ }^{\mathrm{TM}}$ GL was designed to support multiple business functions and incorporates functions into a single database. GL will store large quantities of data to support many functions. The user can control the amount of data at any given time by selecting only the information needed. GL stores information in two types of tables: transaction tables and control tables. Transaction tables store their information by business unit and control tables store their information by SetDs. Within the control tables, a TableSet is a subset of data that defines the accounting structure and processing rules for a particular business unit.

\section{- Business Unit}

The Business Unit panels are used to define each business unit in an organization and determine default journal entry error-handling options that will apply to each. 


\section{- Control Panels}

Most data recorded in control tables are stored by SetID. The SetID panel establishes "ownership" of information. The control tables used by each of the financial applications are divided into groups call TableSet Record Groups. A Record Group is a set of logically and functionally related control tables and views. The Installation Options panels tell the system which applications are installed, the default country code, and how to use the journal auto-numbering feature. The Operator Preferences panels allow the user to set defaults authorizing operators to use PeopleSoft ${ }^{\mathrm{TM}}$ financial applications. The Account Types panel provides the input process to identify account types. The Detail Calendar is used to identify accounting periods. The Define ChartFields panels consist of Account, Department, and Product. ChartFields are used to classify accounting transactions created in subsystems or entered directly into general ledger. The TimeSpans panel provides the method to easily select and retrieve ledger balances for use in allocations, PeopleSoft ${ }^{\mathrm{TM}}$ Vision reporting, and Budgeting.

- Process Scheduler

Process Scheduler is used to run GL allocations, average daily balances, build combination data, year-end closing, consolidations, journal edit, journal post, multicurrency processing, and summary ledger. In addition, Process Scheduler is used to run Structured Query Reports (SQR) and Crystal Reports. A Run Control is established to store parameter criteria for each of the processes.

\section{- Tree Manager}

Once the chart of accounts is created, the ChartFields can be defined for summarization rules, reporting relationships, and organizational rollups using the Tree diagrams. Trees allow the capabilities to organize and optionally maintain ChartField values.

\section{- ChartField Edit Combinations}

In addition to editing for individual ChartField values, the edit process can use ChartField Edit Combination panels to expand ChartField values that are dependent on each other.

- Ledger

The Ledger Template panels are used to identify the records and fields that PeopleSoft ${ }^{\mathrm{TM}}$ GL will use to update ledgers during batch processing. A ledger is a set of posted balances that represent a set of books for a Business Unit. PeopleSoft ${ }^{\text {TM }}$ GL supports both detail and summary ledgers by using the Detail Ledger and Summary Ledger panels. Detailed Ledger Group panel provides for one primary ledger and zero to nine secondary ledgers. Each ledger within the ledger group shares a common physical structure as defined on the Ledger Template, but each also has unique characteristics such as its own base currency. The Ledgers for a Unit panel specifies the ledger type, the periods that are open, the year to which any adjustments should be posted, and the rules for handling journal processing errors. 
RPP-4773, Rev. 0

- Journal Processing

Journal Processing provides the means to efficiently enter and track financial transactions. Panel inputs identify the origin of a transaction or group of transactions. SpeedTypes define any number of valid ChartField combinations for journal entry. There are edit panels to define specific edit criteria, inquiry panels for detail and summary journal data, panels to define posting and non-posting of journal entries, and schedules panel to create schedules to automate and control the generation of Standard Journal Entries. Panels are provided for the setup of Unit of Measure and associate it with a Statistical Account or a Statistics Code. Year-end closing will use the Closing Rules panels and the Process Closing panel.

\section{PeopleSoft ${ }^{\mathrm{TM}}$ PROJECTS MODULE}

PeopleSoft ${ }^{\mathrm{TM}}$ Projects will support multiple functions such as creating projects, accumulating project costs, performing allocations, producing customer bills, and creating assets. With Table Setup panels, Projects can mirror the accounting and processing rules of the business unit.

\section{- General Options}

The General Options are shared across multiple PeopleSoft ${ }^{\mathrm{TM}}$ Financial applications. Projects rely on tables to store not only business transactions, but also financial structure and processing rules. Before entering and processing data, the basic accounting structure will need to be set up using control tables. Processes can be set up to run instantly, to run once, or to run on a recurring basis. Process Monitor, which can be set up to automatically start each time a process is initiated, shows the status of the processes and enables the user to cancel, delete, hold, or requeue them if necessary.

\section{- Project Control}

The Integration Template panels are used to define integration between PeopleSoft ${ }^{\mathrm{TM}}$ Projects and other financial applications. The Project Types panel is used to group projects of similar functionality. The Activity Types panel is used to group activities into like categories, which facilitates analysis of activities across projects. The Analysis Types panel is used to assign individual resource transactions to track costs as they move through different stages of a project. Analysis Groups are created through the Analysis Groups panel. The Analysis Groups are used in the Flexible Analysis Drilldown panel to analyze projects. The Resource Types panel assigns individual resource transactions to individual costs. Resource Category panel is used to specifically define the individual resources. Resource Subcategories panel allows another level at which to define and track resources. The Relate Type/Category is used to set up a relationship between Resource Types, Resource Categories, and Resource Subcategories. This allows the user to limit data entry options for specific fields. The Phase Types panel provides the means to identify what phase of the project the project schedule represents. The Status Types panel is used to define status types to track changes in the status of the projects and activities. The Events panel is used for setting project approvals. The Milestone Types panel enables the user to create milestones to use in contracts or to create reports or bill. 
The Milestone Definition panel is used to identify individual Milestones for each type. The Quality Types panel is used to identify the criteria on which activities can be rated for quality. This panel enables the user to group and analyze projects whose quality ratings are based on the same criteria.

\section{- Project Setup}

Projects provide the basis to which activities and resources are attached and through which costs are tracked. For each project, there is the option to capture vast amounts of additional detail. The panels record detailed project descriptions, track the project's status from initiation to closure, and specify the project manager who has responsibility for each project.

\section{- Project Activity}

The Activity panels consist of Definition, Description, Status, Location, Resource List, Resource Detail, Resource ChartFields, and Resource Journal. These panels allow the creation of individual tasks or events that make up a project. The Activity Quality Detail and Summary panel enables the user to include the quality ratings as part of the information stored with individual activities.

\section{- Accumulating Costs}

Most resource transactions will be entered automatically into the system via integration with other financial systems. The Accumulate Costs Activity panel enables the user to enter resource transactions manually. The Resource Adjustment panel provides the means to make adjustments to resource transactions after they have been added to an activity while retaining a record or audit trail of the changes. PeopleSoft ${ }^{\mathrm{TM}}$ Projects provides a series of panels that enables the user to review the costs for a project based on different integration criteria. Each panel displays resource transactions for a single project only. The view panels are for Purchase Orders, Vouchers, Inventory Items, Employees, Assets, Journal Entries, and Accounts Receivable.

\section{- Analyze Projects}

PeopleSoft ${ }^{\mathrm{TM}}$ Projects provides a series of panels that enables the user to analyze project data once the user has created projects and activities and began incurring costs. View panels provided are the Project Financial Summary, Project Resource Summary, Budgetto-Actual Variance, Over-Budget Resources, Under-Budget Resources, Project to Complete, Flexible Analysis Drilldown, Projects Drill Up, and Flexible Time Span Analysis. 
RPP-4773, Rev. 0

\section{- Journal Generator}

The Journal Generator panels provide a means to take accounting entries from Projects and format them into journal entries. The Journal Generator reads distribution lines from Projects and transforms the data into journal entries that can be posted to general ledger balance.

\section{- Allocation}

The Allocation panels are used to distribute revenue, expense, and statistical quantities from one project to other projects and activities, from general ledger accounts to projects in Projects, and from projects in one business unit to projects in another business unit. A common use of allocations is to distribute expenses within a project or across projects so that each project, activity, or resource transaction recognizes a reasonable share of that expense. The panels enable the user to save allocation specifications so that standard allocations don't have to be recreated. The TimeSpans panel automates the determination of accounting periods for these allocations, and selects output options to create journal entries and create a calculations log for a complete audit trail.

\section{- Projects Integration}

The extensive integration capabilities of the Projects model enable the user to access project information when and where it is needed. Information can be pulled into Projects from other PeopleSoft ${ }^{\mathrm{TM}}$ modules, and Projects can drill back to those systems to retrieve details that may be crucial for decision-making. Information can be exchanged on a daily basis, and all information is fed into Projects as resource transactions already tagged with the appropriate analysis types.

\section{- Projects Billing}

Projects provide panels for flexible billing options. Billing can be based on individual resource billing rates or on percentage complete. Projects handle the collecting of costs, the defining of rates, and the tracking of percentage of completion necessary for calculating amounts for billing, much of which is done in conjunction with any contractual agreements with customers.

\section{- Flexible Formulas}

The Flexible Formula panels prove the unique ability to define simple or complex calculations based on any field within Projects, including customized fields.

\section{- Creating Assets}

The Asset panels enable the user to manage physical assets from cradle to grave. Assets panels provide detailed cost control from defining the physical asset to placing it in service and maintaining it, and finally to retiring the asset. Assets can be defined, preclosed, closed, and retired from within Projects. 


\section{PeopleSoft ${ }^{\mathrm{TM}}$ SYSTEM MODULES}

- Inquiry

Inquiry contains preformatted inquiry routines that are used for general-purpose displays of any item.

\section{- Administration}

Administration contains processing routines that generally are not considered to be part of the main functional categories, which may include user tables, security, report tables, and data dictionary.

- Reporting

Reporting functions that the user has access to may include pre-defined request reports, scheduled processing reports, available queries, or the Variable Report Writer.

\section{- Interface}

Interface mechanisms are used for invoking or interrupting the entity, for communicating through parameters, for common data areas or messages, and for direct access to internal data. Interface will allow the user to extract data from an external software system that is needed to perform the data entity correction.

- Mass Change

Mass Change is a SQL generator that can be used to create custom functionality. Mass Change can set up a series of Insert, Update, or Delete SQL statements that users can use to perform business functions that are specific to the business flow. These changes can be made to run real-time or run in the background using scheduled processing. 
RPP-4773, Rev. 0

This page intentionally left blank. 
RPP-4773, Rev. 0

APPENDIX F

\section{ACRONYMS}

F-i 
RPP-4773, Rev. 0

This page is intentionally left blank. 


\section{ACRONYMS}

\begin{tabular}{ll} 
AAA & Action/Alert/Awareness \\
ACWP & Actual Cost of Work Performed \\
BCR & Baseline Change Request \\
BCWP & Budgeted Cost of Work Performed \\
BCWS & Budgeted Cost of Work Scheduled \\
BMS & Business Management System \\
BWHC & B\&W Hanford Company \\
CACN & Cost Account Charge Number \\
CMM & Capability Maturity Model \\
COA & Code of Account \\
COBRA & Consolidated Omnibus Budget Reconciliation Act \\
COR & Contracting Officer's Representative \\
COTS & Commercial Off-The-Shelf \\
CPM & Critical Path Manager \\
DCN & Design Change Notice \\
DCP & Design Change Package \\
DOE & U.S. Department of Energy \\
ECC & Engineering Change and Control \\
EDI & Electronic Data Interchange \\
EDM & Electronic Data Management \\
FDH & Fluor Daniel Hanford, Inc. \\
FY & Fiscal Year \\
GL & General Ledger \\
HANDI & Hanford Data Integrator System \\
HANDI 2000 & Hanford Data Integration 2000 Project \\
HSTD & Hanford Site Technical Database \\
ICD & Interface Control Document \\
ID & Identification \\
INCOSE & International Council on Systems Engineering \\
INDUS & Indus International, Inc. \\
LMHC & Lockheed Martin Hanford Corporation \\
LMSI & Lockheed Martin Services, Incorporated \\
N/A & not available \\
OLE & Object Linking and Embedding \\
OPS & Operations \\
ORP & Office of River Protection \\
P3 & Primavera Project Planning \\
PA & Performance Agreement \\
PHMC & Project Hanford Management Contract \\
QA & Quality Assurance \\
OPS & Operations \\
QC & Quality Control \\
& \\
\hline
\end{tabular}

\footnotetext{
${ }^{1}$ Primavera Project Planner is a trademark of Primavera Systems Inc., Bala Cynwyn, Pennsylvania.
} 
QM

RCR

RFP

RFQ

RL

RPP

SE

SE\&I

SEMP

SQR

S/RID

TBR

TEMP

TIS

TWR

TWRS

WBS

WMS
Quality Management

Review Comment Record

Request for Proposal

Request for Quote

U.S. Department of Energy, Richland Operations Office

River Protection Project

Systems Engineering

Systems Engineering and Integration

Systems Eingineering Management Plan

Structured Query Report

Standards/Requirements Identification Document

Technical Baseline Report

Testing and Evaluation Management Plan

Time Information System

Tank Waste Remediation

Tank Waste Remediation System

Work Breakdown Structure

Work Management System 
RPP-4773, Rev. 0

APPENDIX G

REFERENCES AND BIBLIOGRAPHY

G-i 
RPP-4773, Rev. 0

This page intentionally left blank.

G-ii 


\section{RPP-4773, Rev. 0}

\section{REFERENCES}

The following documents were called out in the text of this document.

99-PID-105, Fiscal Year (FY) 2000 Baseline Updating Guidance for Multi-Year Work Plans (BUG-MYWP), internal correspondence dated June 21, 1999, from K. A. Klein, U.S. Department of Energy, Richland Operations Office, Richland, Washington, and R. T. French, U.S. Department of Energy, Office of River Protection, Richland, Washington, to President, Fluor Daniel Hanford, Inc., Richland, Washington.

HNF-1743, 1997, HANDI 2000 Project Execution Plan, HNF-1743, Rev. 0, Lockheed Martin Hanford Company, for Fluor Daniel Hanford, Inc., Richland, Washington.

HNF-IP-0842, 1998, RPP Administration, Rev. 0, Volume IV, Section 2.14, "Systems Engineering Maturity Assessment and Compliance Guide," Lockheed Martin Hanford Company, Richland, Washington. 


\section{BIBLIOGRAPHY}

The following documents were used in preparation of this report, but have not been called out specifically in the text.

Indus International, 1997, PASSPORT Accounts Payable Product Description, INDUS Baseline Release 6.0.0, TIGB-0205-0897-4, The Indus Group, Inc., San Francisco, California.

Indus International, 1997, PASSPORT Contract Management Product Description, INDUS Baseline Release 6.0.0, TIGB-0324-0897-1, The Indus Group, Inc., San Francisco, California.

Indus International, 1997, PASSPORT Document Management Product Description, INDUS Baseline Release 6.0.0, TIGB-0126-0897-7, The Indus Group, Inc., San Francisco, California.

Indus International, 1997, PASSPORT Engineering Change Control Product Description, INDUS Baseline Release 6.0.0, TIGB-0127-0897-7, The Indus Group, Inc., San Francisco, California.

Indus International, 1997, PASSPORT Inventory Management Product Description, INDUS Baseline Release 6.0.0, TIGB-0051-0897-8, The Indus Group, Inc., San Francisco, California.

Indus International, 1997, PASSPORT Labor Entry and Reporting Product Description, INDUS Baseline Release 6.0.0, TIGB-0288-0897-1, The Indus Group, Inc., San Francisco, California.

Indus International, 1997, PASSPORT Project Management Product Description, INDUS Baseline Release 6.0.0, TIGB-0313-0897-1, The Indus Group, Inc., San Francisco, California.

Indus International, 1997, PASSPORT Purchasing Product Description, INDUS Baseline Release 6.0.0, TIGB-0049-0897-9, The Indus Group, Inc., San Francisco, California.

Indus International, 1997, PASSPORT Work Management Product Description, INDUS Baseline Release 6.0.0, TIGB-0045-0897-10, The Indus Group, Inc., San Francisco, California.

Johnson, Adria L., 1998, System Design Description for HANDI 2000 Business Management System, HNF-2857, Rev. 0, Lockheed Martin Services, Inc., for Fluor Daniel Hanford, Inc., Richland, Washington. 
RPP-4773, Rev. 0

APPENDIX H

INFORMATION SYSTEMS ASSESSMENT PROJECT PARTICIPANTS

$\mathrm{H}-\mathrm{i}$ 
RPP-4773, Rev. 0

This page intentionally left blank.

$\mathrm{H}$-ii 


\section{INFORMATION SYSTEMS ASSESSMENT PROJECT PARTICIPANTS}

\section{Lockheed Martin Hanford Company}
A. Michael David, Project Director Donald M. McDaniel, Vice President Lyle G. Peck, PA Owner Gar C. Norman Philip A. Craig Karen M. Carlson Tony L. Jennings Patricia J. Sparks

\section{Lockheed Martin Service, Incorporated}

Adria L. Johnson, Project Manager P. B. (Brian) Isaacs Terri M. Lutter

\section{Fluor Daniel Hanford}

M. L. (Skip) Heinemeyer, Project Monitor Paul C. Felts Andrew J. Watts Kevin M. McIntosh

\section{U.S. Department of Energy, Office of River Protection}

Hal J. Wacek, Project Monitor

Dan J. Francis, Project Monitor

\section{B\&W Hanford Company}

Robert R. Beach

\section{Indus International}

Douglas E. Morgan

Denny McCoy

\author{
Russell J. Murkowski \\ Charles (Bob) R. Hutchins \\ John B. Payne \\ Bill W. Root Jr. \\ Michael W. Wells \\ Diana L. Marquez \\ Stephen L. Spencer
}

Kelly A. Crace

M. (Maggi) L. Nielsen

Rebecca L. Rice 
RPP-4773, Rev. 0

This page intentionally left blank. 
RPP-4773, Rev. 0

APPENDIX I

\section{PRIORITIES FOR IMPLEMENTATION} AND DEVELOPMENT ACTIVITIES 
RPP-4773, Rev. 0

This page intentionally left blank. 
RPP-4773, Rev. 0

\section{APPENDIX I \\ PRIORITIES FOR IMPLEMENTATION AND DEVELOPMENT ACTIVITIES}

The suggested priority list for implementation and development of modules/systems is as follows:

1. Implement PassPort ${ }^{\mathrm{TM}}$ Work Management, Project Control, Action Tracking, and Labor Entry modules.

2. Develop a Project Scheduling Interface.

3. Develop an Executive Information System.

4. Implement PassPort ${ }^{\mathrm{TM}}$ Engineering Change Control module.

5. Address Configuration Management/Workflow-Implement Curator.

6. Develop a Requirements Management Interface.

7. Implement PassPort ${ }^{\mathrm{TM}}$ Document Management, Procurement Engineering, Lock and Tag, Personal Qualifications Data, and Radiation Exposure modules. 
RPP-4773, Rev. 0

This page intentionally left blank. 
-4773, Rev. 0

\section{DISTRIBUTION}

Onsite

Pacific Northwest National Laboratory

Hanford Technical Library

Lockheed Martin Services, Inc.

Johnson, A. L.

G1-22

Central Files

Document Processing Center

Lockheed Martin Hanford Corporation

Craig, P. A.

R1-04

McDaniel, D. M.

$\mathrm{H} 7-06$

Peck, L. G.

H7-06 
-4773, Rev. 0

This page intentionally left blank.

Distr-2 